In the format provided by the authors and unedited.

\title{
Single helically folded aromatic oligoamides that mimic the charge surface of double-stranded B-DNA
}

Krzysztof Ziach (1), Céline Chollet', Vincent Parissi², Panchami Prabhakaran (1) ', Mathieu Marchivie $\mathbb{1 D}^{3}$, Valentina Corvaglia $\mathbb{D}^{1}$, Partha Pratim Bose ${ }^{1}$ 1, Katta Laxmi-Reddy', Frédéric Godde1, Jean-Marie Schmitter', Stéphane Chaignepain', Philippe Pourquier (iD ${ }^{4}$ and Ivan Huc ${ }^{10}$,5*

'Univ. Bordeaux - CNRS - IPB, CBMN Laboratory (UMR5248), Institut Européen de Chimie et Biologie, Pessac, France. ²Univ. Bordeaux - CNRS, Laboratoire de Microbiologie Fondamentale et Pathogénicité (UMR 5234), Bordeaux, France. ${ }^{3}$ Univ. Bordeaux - CNRS, ICMCB (UPR9048), Pessac, France. ${ }^{4}$ INSERM U1194, Institut de Recherche en Cancérologie de Montpellier \& Université de Montpellier, Montpellier, France. ${ }^{5}$ Present address: Department of Pharmacy, Ludwig-Maximilians-Universität, München, Germany. *e-mail: ivan.huc@cup.Imu.de 


\section{Supplementary Information for}

Single helically folded aromatic oligoamides that mimic the charge surface of double-stranded B-DNA

Krzysztof Ziach, Céline Chollet, Vincent Parissi, Panchami Prabhakaran, Mathieu Marchivie, Valentina Corvaglia, Partha Pratim Bose, Katta Laxmi-Reddy, Frédéric Godde, Jean-Marie Schmitter, Stéphane Chaignepain, Philippe Pourquier, Ivan Huc*

Correspondence to: ivan.huc@cup.lmu.de

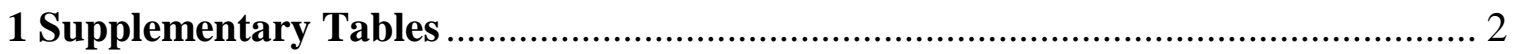

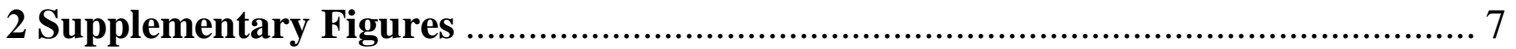

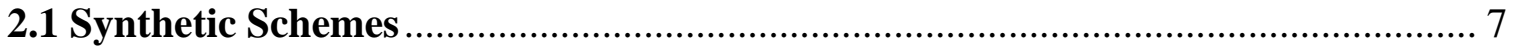

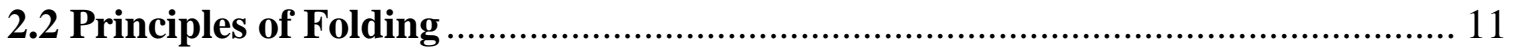

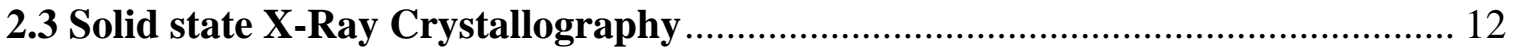

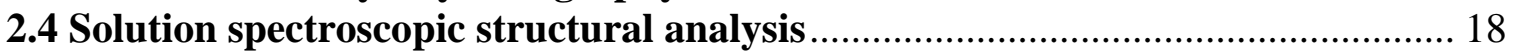

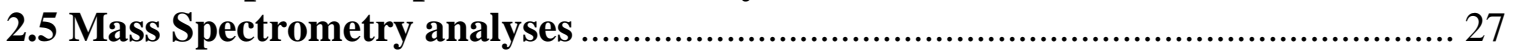

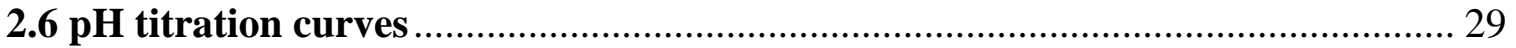

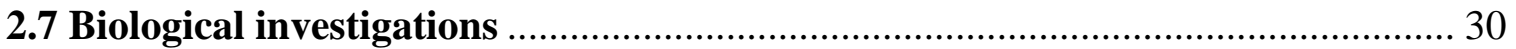

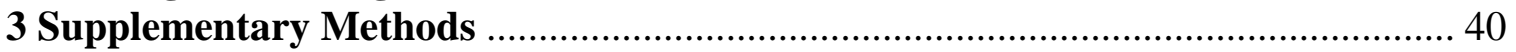

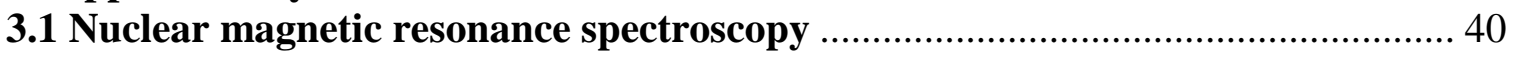

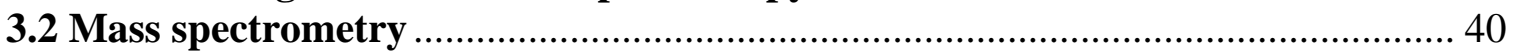

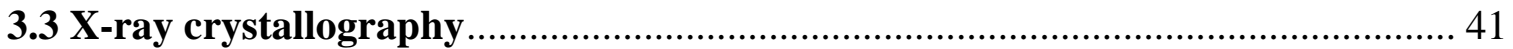

3.4 pKas measurement of phosphonate oligomers .................................................. 44

3.5 Surface plasmon resonance (SPR) .............................................................. 44

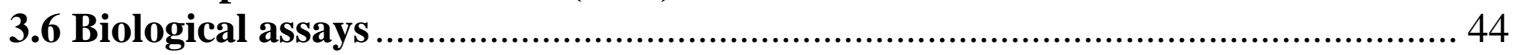

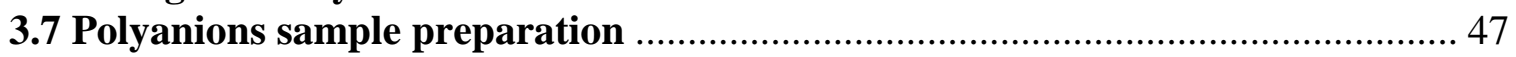

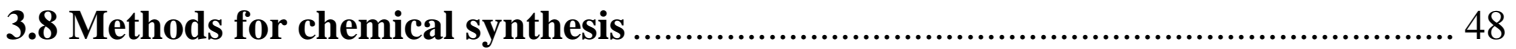

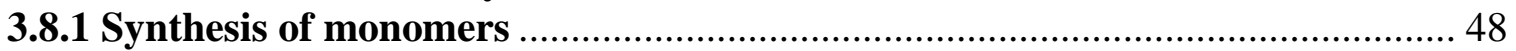

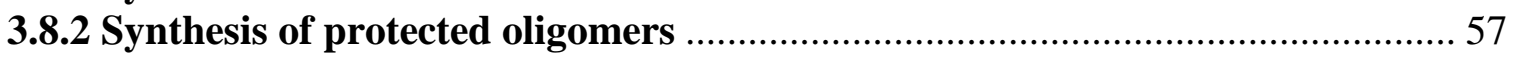

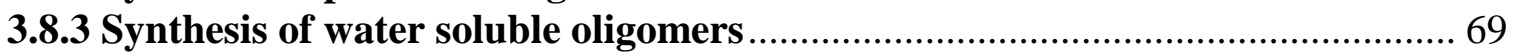

3.8.4 Synthesis of oligomer-nucleotide conjugate............................................... 71

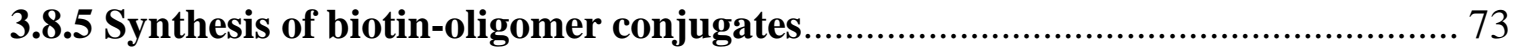

3.8.6 Synthesis of model phosphonate monomers ................................................. 74

3.8.7 HPLC traces, ${ }^{1} \mathrm{H}$ NMR and ${ }^{13} \mathrm{C}$ NMR spectra of purified new synthetic

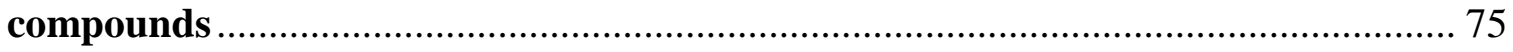




\section{Supplementary Tables}

Supplementary Table 1. Crystal data and structure refinement for $\operatorname{Boc}\left({ }^{\mathrm{m}} \mathbf{Q} \mathbf{Q}^{5}\right)_{4} \mathrm{OBn}$ (S42).

$\begin{array}{cc}\text { Formula } & \mathrm{C}_{140} \mathrm{H}_{168} \mathrm{~N}_{16} \mathrm{O}_{39} \mathrm{P}_{8} \\ M / g . \text { mol }^{-1} & 2946.65 \\ \text { Crystal system } & \text { triclinic } \\ \text { Space group } & \mathrm{P}-1 \\ \text { a/A } & 17.006(3) \\ b / \AA & 20.157(4) \\ \text { c/A } & 24.463(5) \\ \alpha /{ }^{\circ} & 75.85(3) \\ \beta /{ }^{\circ} & 69.66(3) \\ \gamma /{ }^{\circ} & 85.93(3) \\ V / \AA^{3} & 7623(3) \\ T / K & 100 \\ Z & 2 \\ \rho / g \text { cm }^{-1} & 1.284 \\ \text { size }(\text { mm }) & 0.20 \times 0.15 \mathrm{x} 0.10 \\ \lambda / \AA & 1.54178 \\ \mu / m^{-1} & 1.53 \\ \text { Total reflections } & 99875 \\ \text { Unique data } & 26277 \\ R_{\text {int }} & 0.063 \\ \text { parameters/ } & 1828 / 1941 \\ \text { restraints } & 0.125 / 0.319 \\ \text { Rl, wR2 } & 1.26 \\ \text { goodness offit } & 1059496 \\ \text { CCDC \# } & \end{array}$

Supplementary Table 2. Crystal data and structure refinement for Boc $\left({ }^{\mathrm{m}} \mathbf{Q} \mathbf{Q}^{4}\right)_{8} \mathrm{OBn}$ (S31).

\begin{tabular}{|c|c|}
\hline $\begin{array}{l}\text { Formula } \\
\text { M/g.mol }\end{array}$ & $\begin{array}{c}\mathrm{C}_{260} \mathrm{H}_{304} \mathrm{~N}_{32} \mathrm{O}_{83} \mathrm{P}_{16} \\
5700.85\end{array}$ \\
\hline Crystal system & Triclinic \\
\hline Space group & $P-1$ \\
\hline$a / \AA$ & $22.058(8)$ \\
\hline$b / \AA$ & $36.936(13)$ \\
\hline$c / \AA$ & $39.490(12)$ \\
\hline$\alpha /^{\circ}$ & $91.137(15)$ \\
\hline$\beta /{ }^{\circ}$ & $101.582(3)$ \\
\hline$\gamma /{ }^{\circ}$ & $105.808(8)$ \\
\hline$V / \AA^{3}$ & 30232 (18) \\
\hline$T / K$ & 120 \\
\hline$Z$ & 4 \\
\hline$\rho / \mathrm{g} \mathrm{cm}^{-1}$ & 1.253 \\
\hline size (mm) & $0.10 \times 0.10 \times 0.05$ \\
\hline$\lambda / A$ & 1.54178 \\
\hline$\mu / \mathrm{mm}^{-1}$ & 1.54 \\
\hline Total reflections & 337333 \\
\hline Unique data & 85176 \\
\hline$R_{\text {int }}$ & 0.116 \\
\hline $\begin{array}{l}\text { parameters/ } \\
\text { restraints }\end{array}$ & $5923 / 7126$ \\
\hline$R 1, w R 2$ & $0.176,0.483$ \\
\hline goodness of fit & 1.45 \\
\hline CCDC \# & 1059495 \\
\hline
\end{tabular}


Supplementary Table 3. Crystal data and structure refinement for $\operatorname{Boc}\left({ }^{\mathrm{m}} \mathbf{Q Q}^{4}\right)_{8} \mathrm{OTMSE}$.

\begin{tabular}{|c|c|}
\hline $\begin{array}{l}\text { Formula } \\
M / \text { g. }^{2} l^{-1}\end{array}$ & $\begin{array}{c}\mathrm{C}_{258} \mathrm{H}_{310} \mathrm{~N}_{32} \mathrm{O}_{83} \mathrm{P}_{16} \mathrm{Si} \\
5830.34\end{array}$ \\
\hline Crystal system & Monoclinic \\
\hline Space group & $C 2 / c$ \\
\hline$a / \AA$ & $42.984(2)$ \\
\hline$b / \AA$ & $52.9718(14)$ \\
\hline$c / \AA$ & $33.962(2)$ \\
\hline$\alpha /^{\circ}$ & 90 \\
\hline$\beta /{ }^{\circ}$ & $126.304(2)$ \\
\hline$\gamma /{ }^{\circ}$ & 90 \\
\hline$V / \AA^{3}$ & $62317(5)$ \\
\hline$T / K$ & 120 \\
\hline$Z$ & 8 \\
\hline$\rho / \mathrm{g} \mathrm{cm}^{-1}$ & 1.243 \\
\hline size $(\mathrm{mm})$ & $0.10 \times 0.10 \times 0.05$ \\
\hline$\lambda / A$ & 1.54178 \\
\hline$\mu / \mathrm{mm}^{-1}$ & 1.77 \\
\hline Total reflections & 441727 \\
\hline Unique data & 60666 \\
\hline$R_{\text {int }}$ & 0.214 \\
\hline $\begin{array}{l}\text { Parameters } \\
\text { /restraints }\end{array}$ & $2572 / 3026$ \\
\hline$R 1, w R 2$ & $0.157,0.362$ \\
\hline goodness of fit & 0.97 \\
\hline $\mathrm{CCDC} \#$ & 1059497 \\
\hline
\end{tabular}

Supplementary Table 4. Crystal data and structure refinement for $\operatorname{Boc}\left({ }^{\mathrm{m}} \mathbf{Q} \mathbf{Q}^{4}\right){ }_{16} \mathrm{OBn}$ (S35).

\begin{tabular}{|c|c|}
\hline Formula & $\mathrm{C}_{508} \mathrm{H}_{592} \mathrm{~N}_{64} \mathrm{O}_{163} \mathrm{P}_{32}$ \\
\hline$M / g \cdot \mathrm{mol}^{-1}$ & 11193.46 \\
\hline Crystal system & Triclinic \\
\hline Space group & P-1 \\
\hline$a / \AA$ & 26.415 \\
\hline$b / \AA$ & 28.192 \\
\hline$c / \AA$ & 42.640 \\
\hline$\alpha /^{\circ}$ & 85.65 \\
\hline$\beta /{ }^{\circ}$ & 75.4 \\
\hline$\gamma /{ }^{\circ}$ & 75.4 \\
\hline$V / \AA^{3}$ & 29746 \\
\hline$T / K$ & 100 \\
\hline$Z$ & 2 \\
\hline$\rho / \mathrm{g} \mathrm{cm}^{-1}$ & 1.250 \\
\hline size $(\mathrm{mm})$ & $0.10 \times 0.10 \times 0.05$ \\
\hline$\lambda / \AA$ & 0.81 \\
\hline$\mu / \mathrm{mm}^{-1}$ & 0.17 \\
\hline Total reflections & 145618 \\
\hline Unique data & 72233 \\
\hline$R_{i n t}$ & 0.079 \\
\hline $\begin{array}{c}\text { parameters/ } \\
\text { restraints }\end{array}$ & $5134 / 6851$ \\
\hline$R 1, w R 2$ & $0.208,0.521$ \\
\hline goodness of fit & 1.69 \\
\hline $\mathrm{CCDC} \#$ & 1059493 \\
\hline
\end{tabular}


Supplementary Table 5. Comparison between the structures of fully protected $\operatorname{Boc}\left({ }^{\mathrm{m}} \mathbf{Q Q}{ }^{4}\right)_{16} \mathrm{OBn}$ (S35) and B-DNA. Root mean square deviation of the phosphorus atom positions in the crystal structure of fully protected $\operatorname{Boc}\left({ }^{\mathbf{m}} \mathbf{Q} \mathbf{Q}^{4}\right){ }_{16} \mathrm{OBn}$ and a 16-base pair B-DNA duplex (in $\AA$ ).

\begin{tabular}{|l|l|}
\hline Boc $\left({ }^{\mathbf{m}} \mathbf{Q Q}^{\mathbf{4}}{ }_{16} \mathrm{OBn}(\mathbf{S 3 5})\right.$ & $\begin{array}{l}\text { RMSD in } \AA \text { from DNA (maximal deviation } \\
\text { observed) }\end{array}$ \\
\hline C-terminal hexadecameric segment & $2.336(3.896)$ \\
\hline N-terminal hexadecameric segment & $2.449(3.771)$ \\
\hline Whole sequence & $2.840(5.836)$ \\
\hline
\end{tabular}

Supplementary Table 6. Comparison between the crystal structures of fully protected $\left({ }^{\mathrm{m}} \mathbf{Q Q}^{4}\right)_{\mathrm{n}}$ oligomers. Root mean square deviation (in $\AA$ ) of the position of the 16 phosphorus atoms. Values in brackets represent the maximum deviation observed between two phosphorous positions.

\begin{tabular}{|c|c|c|c|}
\hline & $\operatorname{Boc}\left({ }^{\mathbf{m}} \mathbf{Q} \mathbf{Q}^{4}\right)_{8} \mathrm{TMSE}$ & $\begin{array}{c}\mathrm{Boc}\left({ }^{\mathbf{m}} \mathbf{Q Q}^{\mathbf{4}}\right)_{8} \mathrm{OBn} \\
\text { mol. }^{c}{ }^{c}\end{array}$ & $\begin{array}{c}\mathrm{Boc}\left({ }^{\mathbf{m}} \mathbf{Q Q} \mathbf{Q}^{4}\right)_{8} \mathrm{OBn} \\
\text { mol. } 2^{d}\end{array}$ \\
\hline $\operatorname{Boc}\left({ }^{\mathbf{m}} \mathbf{Q Q}^{4}\right)_{8}\left({ }^{\mathrm{m}} \mathrm{QQ}^{4}\right)_{8} \mathrm{OBn}^{a}$ & $0.702(1.249)$ & $0.996(1.844)$ & $1.224(2.245)$ \\
\hline \multirow{3}{*}{$\begin{array}{l}\mathrm{Boc}\left({ }^{\mathrm{m}} \mathrm{QQ}^{4}\right)_{8}\left({ }^{\mathrm{m}} \mathbf{Q Q}^{4}\right)_{8} \mathrm{OBn}^{b} \\
\left.\operatorname{Boc}^{\mathrm{m}} \mathbf{Q Q}^{4}\right)_{8} \mathrm{TMSE} \\
\operatorname{Boc}\left({ }^{\mathbf{m}} \mathbf{Q Q}^{4}\right)_{8} \mathrm{OBn} \text { mol. } 1^{c}\end{array}$} & $1.043(1.949)$ & $1.298(2.209)$ & $1.144(2.230)$ \\
\hline & & $1.074(1.896)$ & $1.127(1.872)$ \\
\hline & & & $1.153(2.010)$ \\
\hline
\end{tabular}

${ }^{a}$ N-terminal (first 16 units) segment of Boc $\left({ }^{\mathrm{m}} \mathbf{Q Q}{ }^{4}\right)_{16} \mathrm{OBn}(\mathbf{S 3 5})$

${ }^{b} \mathrm{C}$-terminal segment (last 16 units) of $\operatorname{Boc}\left({ }^{\mathbf{m}} \mathbf{Q} \mathbf{Q}^{\mathbf{4}}\right)_{16} \mathrm{OBn}(\mathbf{S 3 5})$

${ }^{c}$ Independent molecule 1 of the asymmetric unit of $\mathbf{S 3 1}$

${ }^{d}$ Independent molecule 2 of the asymmetric unit of $\mathbf{S 3 1}$ 
Supplementary Table 7. Full assignment of the ${ }^{1} \mathrm{H}$ and ${ }^{13} \mathrm{C}$ chemical shifts of $\left({ }^{\mathrm{m}} \mathrm{QQ}^{4}\right)_{4}$ recorded at $2 \mathrm{mM}$ in $50 \mathrm{mM}$ ammonium bicarbonate $\mathrm{H}_{2} \mathrm{O} / \mathrm{D}_{2} \mathrm{O}(9: 1 \mathrm{vol} / \mathrm{vol})$ based on ${ }^{1} \mathrm{H}$, HMBC and HSQC spectra. Chemical shift values are expressed in ppm. Question marks indicate several unassigned resonances of $\mathrm{C} 11$ carbon atoms.

\begin{tabular}{|c|c|c|c|c|c|c|c|c|}
\hline ring: & A & B & C & D & E & $F$ & G & H \\
\hline H3 & $7.60, \mathrm{~s}$ & $6.85, \mathrm{~s}$ & $6.48, \mathrm{~s}$ & $6.73, \mathrm{~s}$ & $6.17, \mathrm{~s}$ & $6.66, s$ & $6.42, \mathrm{~s}$ & $6.47, \mathrm{~s}$ \\
\hline C3 & 99.07 & 98.55 & 97.33 & 97.71 & 96.83 & 98.45 & 97.09 & 100.18 \\
\hline C4 & 164.60 & 163.52 & 163.55 & 162.98 & 164.08 & 162.72 & 164.66 & 162.83 \\
\hline H5 & $\begin{array}{l}\text { 8.38, d, } \\
J=8.1 \mathrm{~Hz}\end{array}$ & $\begin{array}{c}\text { 7.43, d, } \\
J=7.9 \mathrm{~Hz}\end{array}$ & $\begin{array}{l}8.04, \mathrm{~d} \\
J=7.8 \mathrm{~Hz}\end{array}$ & $\begin{array}{c}\text { 7.12, d, } \\
J=7.9 \mathrm{~Hz}\end{array}$ & $\begin{array}{c}8.09, \mathrm{~d} \\
J=8.0 \mathrm{~Hz}\end{array}$ & $\begin{array}{c}7.08, \mathrm{t} \\
J=8.0 \mathrm{~Hz}\end{array}$ & $\begin{array}{l}\text { 8.27, d, } \\
J=8.0 \mathrm{~Hz}\end{array}$ & $\begin{array}{c}\text { 7.53, d, } \\
J=7.0 \mathrm{~Hz}\end{array}$ \\
\hline C5 & 123.98 & 116.75 & 122.99 & 116.43 & 122.96 & 116.01 & 122.99 & 117.09 \\
\hline H6 & $\begin{array}{c}\text { 7.34, t } \\
J=7.4 \mathrm{~Hz}\end{array}$ & $\begin{array}{c}\text { 7.07, d, } \\
J=6.5 \mathrm{~Hz}\end{array}$ & $\begin{array}{c}\text { 7.44, t } \\
J=7.5 \mathrm{~Hz}\end{array}$ & $\begin{array}{c}\text { 6.83, t } \\
J=8.1 \mathrm{~Hz}\end{array}$ & $\begin{array}{c}\text { 7.61, t } \\
J=7.2 \mathrm{~Hz}\end{array}$ & $\begin{array}{c}\text { 6.81, t } \\
J=7.5 \mathrm{~Hz}\end{array}$ & $\begin{array}{c}\text { 7.75, t } \\
J=7.4 \mathrm{~Hz}\end{array}$ & $\begin{array}{c}\text { 7.20, d, } \\
J=7.5 \mathrm{~Hz}\end{array}$ \\
\hline C6 & 127.47 & 127.34 & 127.46 & 127.30 & 127.67 & 127.09 & 127.57 & 126.55 \\
\hline H7 & $\begin{array}{c}\text { 6.61, d, } \\
J=6.7 \mathrm{~Hz}\end{array}$ & $\begin{array}{l}\text { 7.80, d, } \\
J=7.0 \mathrm{~Hz}\end{array}$ & $\begin{array}{c}\text { 6.97, d, } \\
J=6.7 \mathrm{~Hz}\end{array}$ & $\begin{array}{c}\text { 7.52, d, } \\
J=6.8 \mathrm{~Hz}\end{array}$ & $\begin{array}{c}\text { 7.19, } \mathrm{t} \\
\mathrm{J}=8.3 \mathrm{~Hz}\end{array}$ & $\begin{array}{c}\text { 7.27, d, } \\
J=6.9 \mathrm{~Hz}\end{array}$ & $\begin{array}{c}\text { 8.01, d, } \\
J=8.0 \mathrm{~Hz}\end{array}$ & $\begin{array}{c}\text { 8.03, d, } \\
J=7.8 \mathrm{~Hz}\end{array}$ \\
\hline C7 & 132.28 & 117.34 & 131.37 & 116.87 & 131.97 & 116.03 & 132.08 & 116.43 \\
\hline C8 & 127.81 & 131.56 & 129.84 & 130.99 & 131.78 & 131.19 & 134.33 & 132.58 \\
\hline C9 & 143.55 & 137.37 & 144.55 & 136.07 & 145.55 & 136.49 & 146.73 & 138.00 \\
\hline C10 & 121.63 & 120.59 & 121.40 & 119.33 & 121.60 & 119.51 & 122.35 & 120.24 \\
\hline C11 & $?$ & 166.52 & $?$ & 165.22 & $?$ & 166.48 & $?$ & $?$ \\
\hline H12a & 4.49, brs & $4.06, \mathrm{~m}$ & $\begin{array}{c}4.15, \mathrm{t} \\
J=11.1 \mathrm{~Hz}\end{array}$ & $4.11, \mathrm{~m}$ & $3.95 ; \mathrm{m}$ & $3.99, \mathrm{~m}$ & $3.74, \mathrm{~m}$ & $3.71, \mathrm{~m}$ \\
\hline$H 12 b$ & $\begin{array}{c}\text { 4.35, t } \\
J=10.1 \mathrm{~Hz}\end{array}$ & $4.06, \mathrm{~m}$ & $\begin{array}{c}4.87, \mathrm{t} \\
J=10.2 \mathrm{~Hz}\end{array}$ & $4.08, \mathrm{~m}$ & $3.59, \mathrm{~m}$ & $3.99, \mathrm{~m}$ & $3.69, \mathrm{~m}$ & $3.71, \mathrm{~m}$ \\
\hline C12 & $\begin{array}{c}66.31, d \\
J_{\mathrm{P}-\mathrm{C}}=144 \mathrm{~Hz}\end{array}$ & $\begin{array}{c}65.77, d \\
J_{P-C}=139 \mathrm{~Hz}\end{array}$ & $\begin{array}{c}65.21, d \\
J_{P-C}=157 \mathrm{~Hz}\end{array}$ & $\begin{array}{c}65.57, d \\
J_{P-C}=144 \mathrm{~Hz}\end{array}$ & $\begin{array}{c}65.21, d \\
J_{P-C}=157 \mathrm{~Hz}\end{array}$ & $\begin{array}{c}65.42, d \\
J_{P-C}=141 \mathrm{~Hz}\end{array}$ & $\begin{array}{c}65.43, d \\
J_{P-C}=158 \mathrm{~Hz}\end{array}$ & $\begin{array}{c}65.43, d \\
J_{\mathrm{P}-\mathrm{C}}=158 \mathrm{~Hz}\end{array}$ \\
\hline H13a & $3.78, \mathrm{~m}$ & & $3.78, \mathrm{~m}$ & & $3.58, \mathrm{~m}$ & & $\begin{array}{c}5.06, \mathrm{t} \\
J=12.8 \mathrm{~Hz}\end{array}$ & \\
\hline H13b & 2.59, m & - & $2.56, \mathrm{~m}$ & - & $3.04, \mathrm{~m}$ & - & 5.01, brs & - \\
\hline C13 & 39.38 & & 43.48 & & 42.89 & & 43.67 & \\
\hline $\mathrm{NH}$ & - & 11.19 & 9.82 & 10.22 & 8.95 & 10.65 & 9.12 & 11.68 \\
\hline
\end{tabular}


Supplementary Table 8. Structural features of selected polyanions.

\begin{tabular}{|c|c|c|c|}
\hline Polyanion & Major repeating unit & $\begin{array}{c}\text { Molecular weight } \\
\text { (16 negative charges) }\end{array}$ & $\begin{array}{c}\text { Average } \\
\text { molecular weight }\end{array}$ \\
\hline HEPARIN & Molecular Weight: 665.38 & $\begin{array}{c}\text { Molecular Weight: } \\
2661.52\end{array}$ & 13000-15000 Da \\
\hline $\begin{array}{l}\text { DERMATAN } \\
\text { SULPHATE }\end{array}$ & Molecular Weight: 517.37 & $\begin{array}{c}\text { Molecular Weight: } \\
4138.96\end{array}$ & $30000 \mathrm{Da}$ \\
\hline $\begin{array}{l}\text { HEPARAN } \\
\text { SULPHATE }\end{array}$ & Molecular Weight: 605.38 & $\begin{array}{c}\text { Molecular Weight: } \\
3228.69\end{array}$ & $41000 \mathrm{Da}$ \\
\hline $\begin{array}{c}\text { POLY- } \\
\text { PHOSPHATE }\end{array}$ & $\begin{array}{c}\text { ONa } \\
\text { mO_P_Om } \\
\text { ठ } \\
\text { Molecular Weight: } 101.96\end{array}$ & $\begin{array}{c}\text { Molecular Weight: } \\
1631.36\end{array}$ & $11500 \mathrm{Da}$ \\
\hline $\begin{array}{l}\left({ }^{\mathrm{m}} \mathrm{Q} \mathrm{Q}^{4}\right)_{8} \\
\text { oligomer }\end{array}$ & Molecular Weight: 4885.54 & $\begin{array}{c}\text { Molecular Weight: } \\
4885.54\end{array}$ & - \\
\hline $\begin{array}{l}\text { Random DNA } \\
8 \mathrm{bp}\end{array}$ & $\begin{array}{l}\text { Mixture of random } \\
\text { sequences }\end{array}$ & Molecular Weight: 5280 & - \\
\hline
\end{tabular}




\section{Supplementary Figures}

\subsection{Synthetic Schemes}

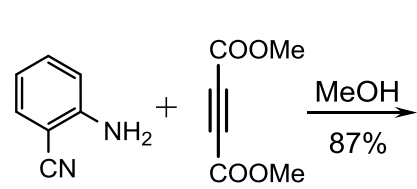<smiles>COC(=O)/C=C(/Nc1ccccc1C)C(=O)OC</smiles><smiles>COC(=O)c1cc(=O)c2ccc(O)c(O)c2[nH]1</smiles><smiles>N#Cc1cccc2c(=O)cc(C(=O)OCc3ccccc3)[nH]c12</smiles>

s3

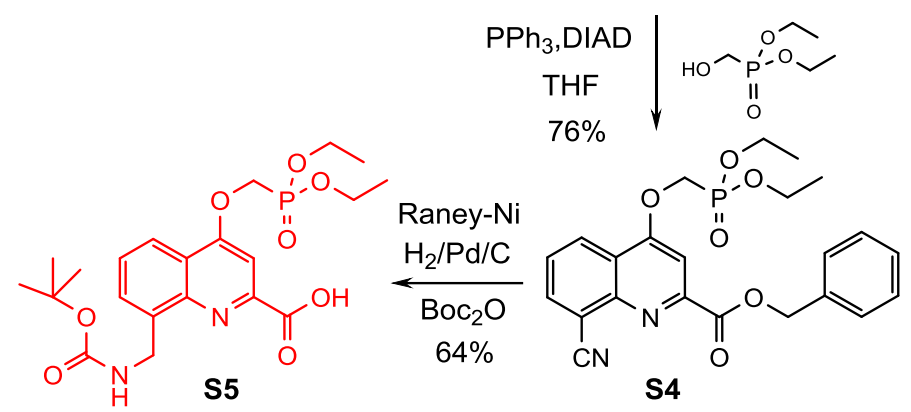

Supplementary Figure 1. Preparation of ${ }^{\mathrm{m}} \mathbf{Q}$ monomer S5.

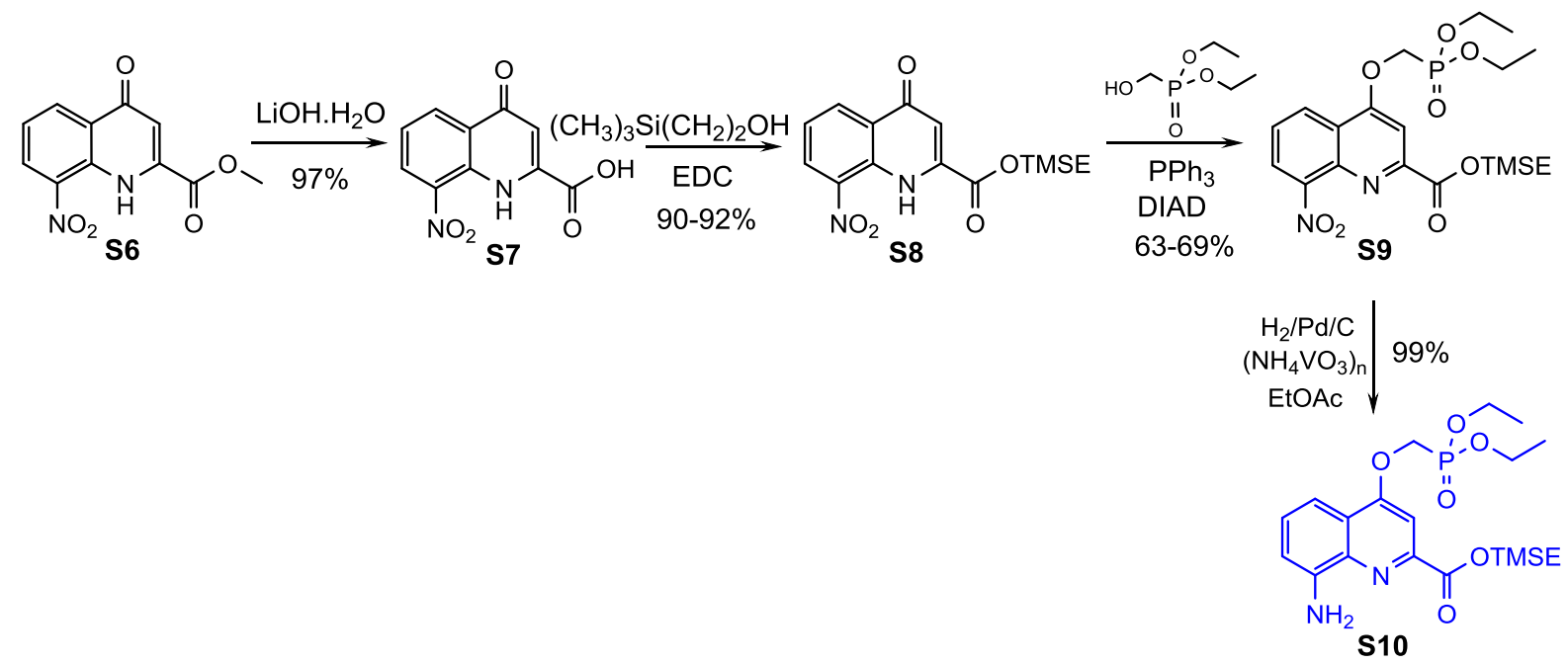

Supplementary Figure 2. Preparation of $\mathbf{Q}^{4}$ monomer S10. 

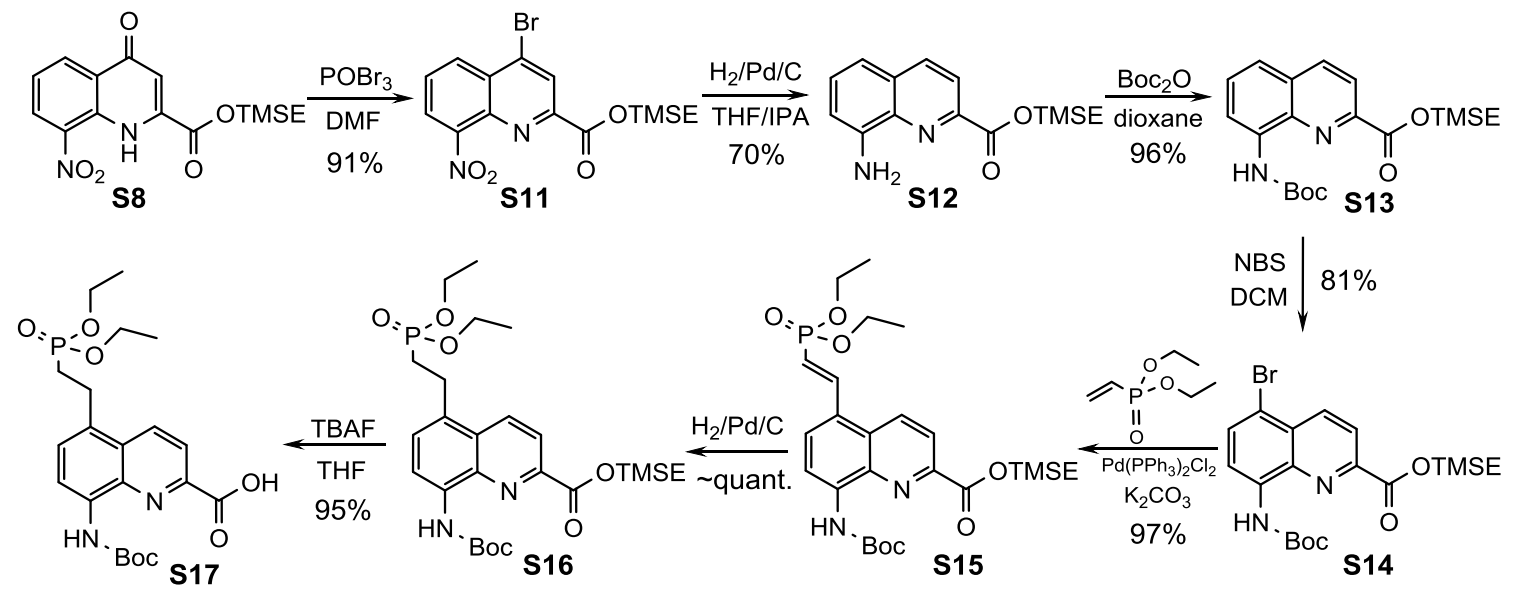

$$
90 \% \mid \begin{aligned}
& \text { 1. } \mathrm{Cs}_{2} \mathrm{CO}_{3} \\
& \text { 2. } \mathrm{BnBr}
\end{aligned}
$$

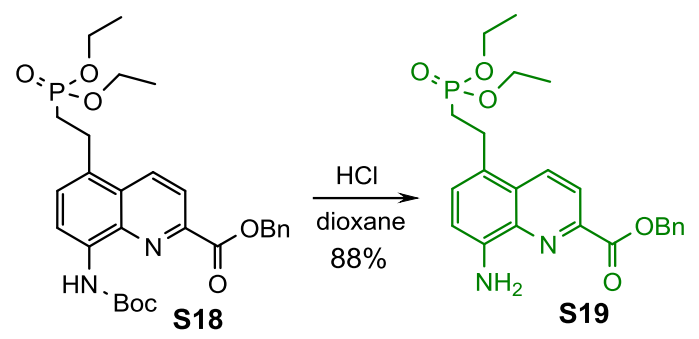

Supplementary Figure 3. Preparation of $\mathbf{Q}^{5}$ monomer S19.<smiles>[R]O[R15](=O)NCc1cccc2c(OCP(=O)(OCC)OCC)cc(C([R])=O)nc12</smiles><smiles></smiles>

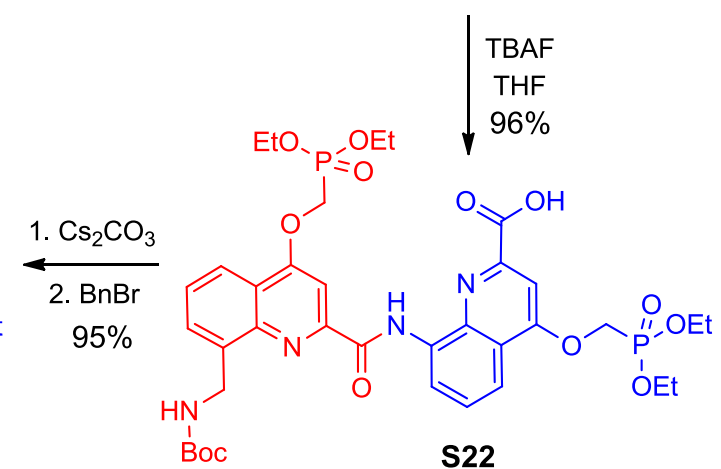

Supplementary Figure 4. Preparation of dimer-acid S22 and dimer S23. 


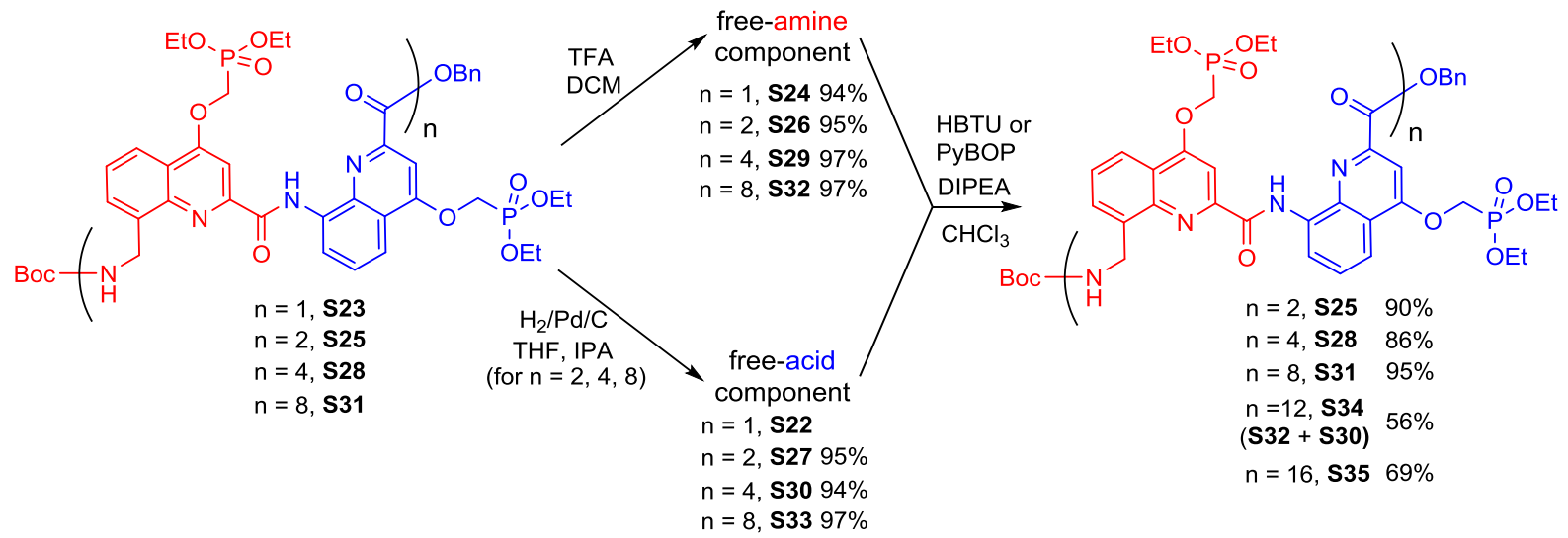

Supplementary Figure 5. Coupling strategy and deprotection for $\left({ }^{\mathrm{m}} \mathrm{QQ}{ }^{4}\right)_{\mathrm{n}}$ oligomers.

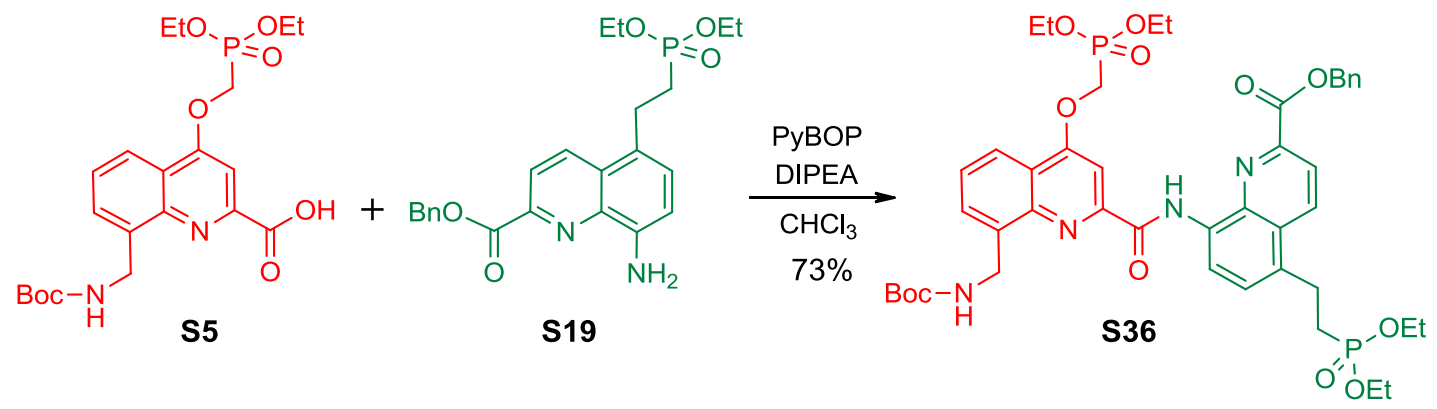

Supplementary Figure 6. Preparation of dimer S36.
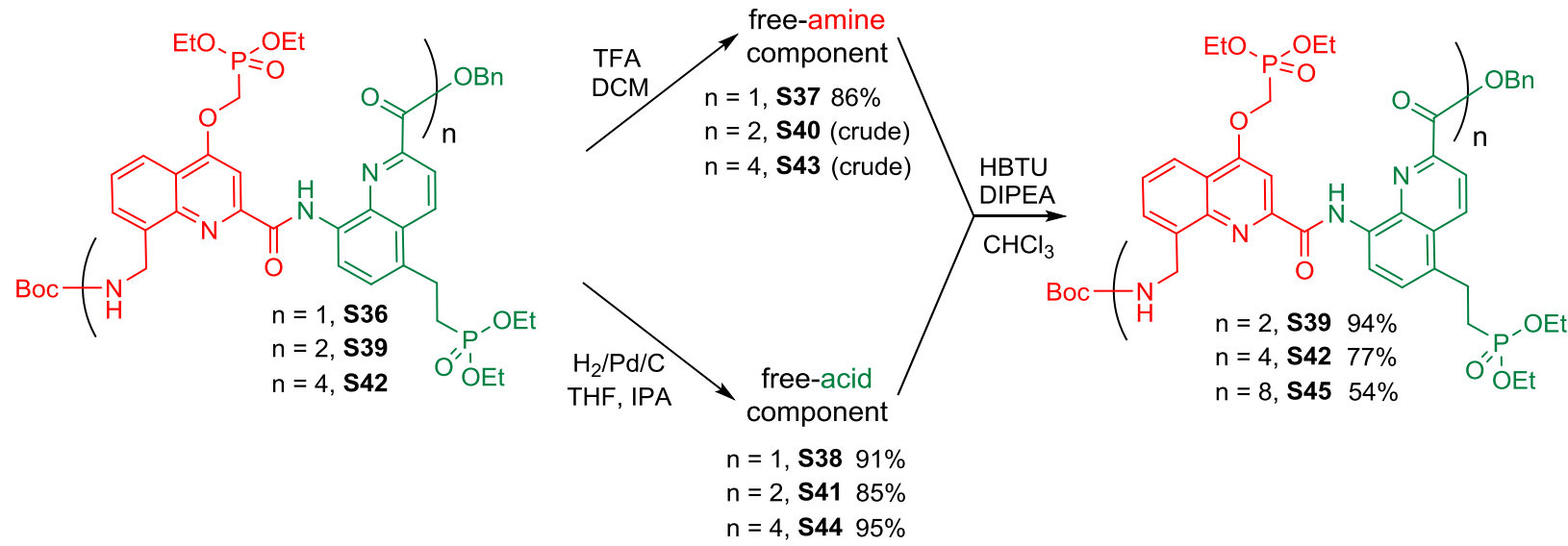

Supplementary Figure 7. Coupling strategy and deprotection for $\left({ }^{\mathrm{m}} \mathbf{Q} \mathbf{Q}^{5}\right)_{\mathrm{n}}$ oligomers. 

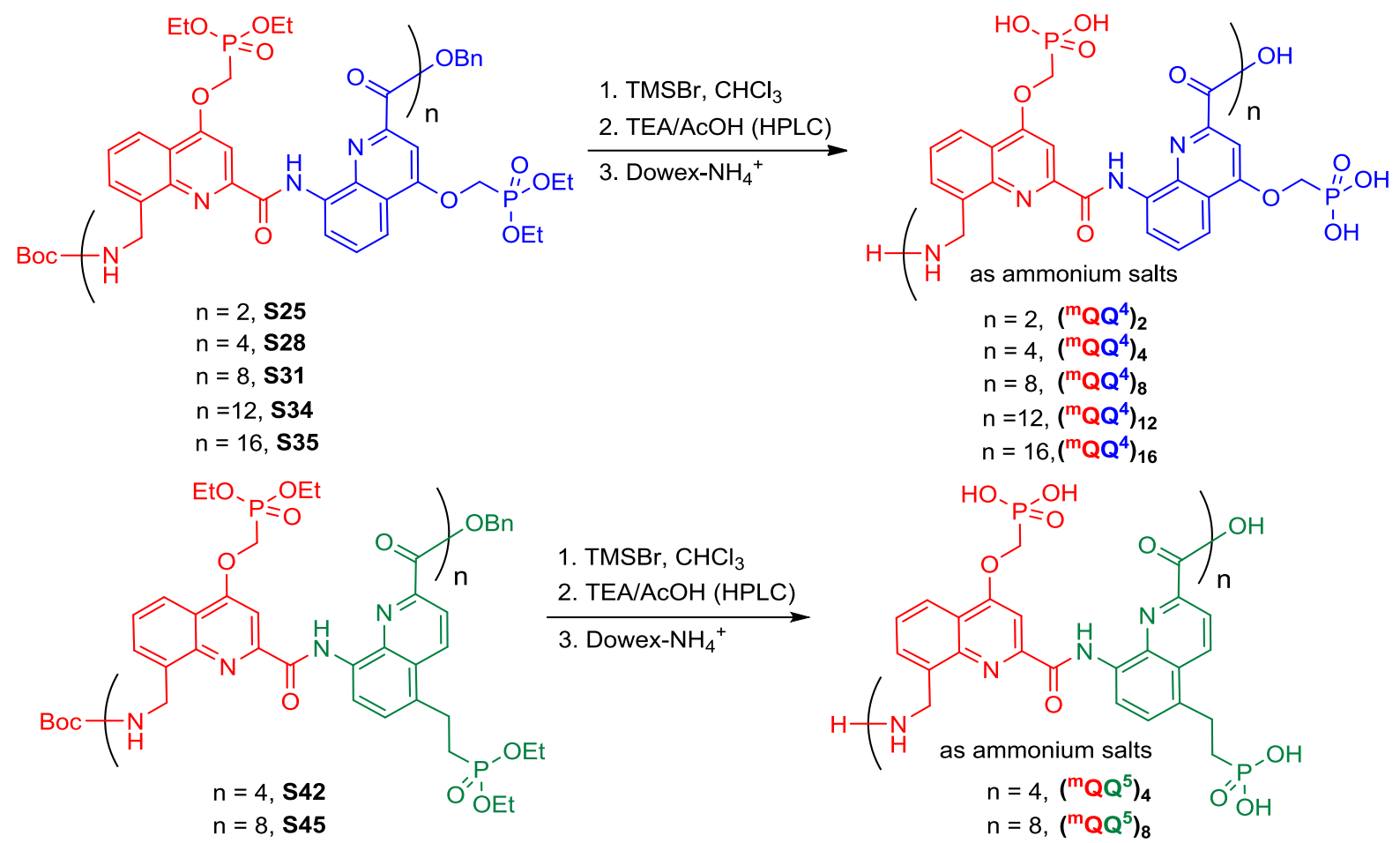

Supplementary Figure 8. Deprotection of $\left({ }^{\mathrm{m}} \mathbf{Q Q}^{4}\right)_{\mathrm{n}}$ oligomers and $\left({ }^{\mathrm{m}} \mathrm{QQ}^{5}\right)_{\mathrm{n}}$ oligomers.

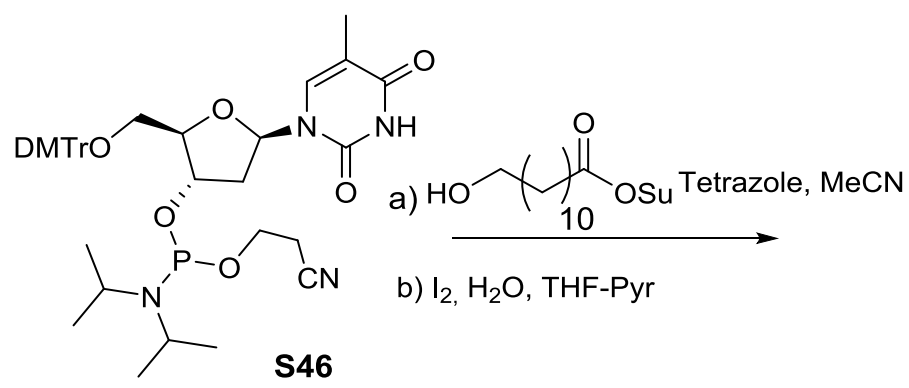<smiles>COCC[C@H]1OC(n2cc(C)c(=O)[nH]c2=O)C[C@H]1OP(=O)(OCCN)OCC(=O)O[Na]</smiles><smiles>Cc1cn(C2CC(OP(=O)(O)OCC(C)(C)C(=O)OCC(C)(C)C)[C@@H](CO)O2)c(=O)[nH]c1=O</smiles>

Foldamer: Nucleotide $(1: 3)$,
TEAA, pH: 8.7, DMF, rt
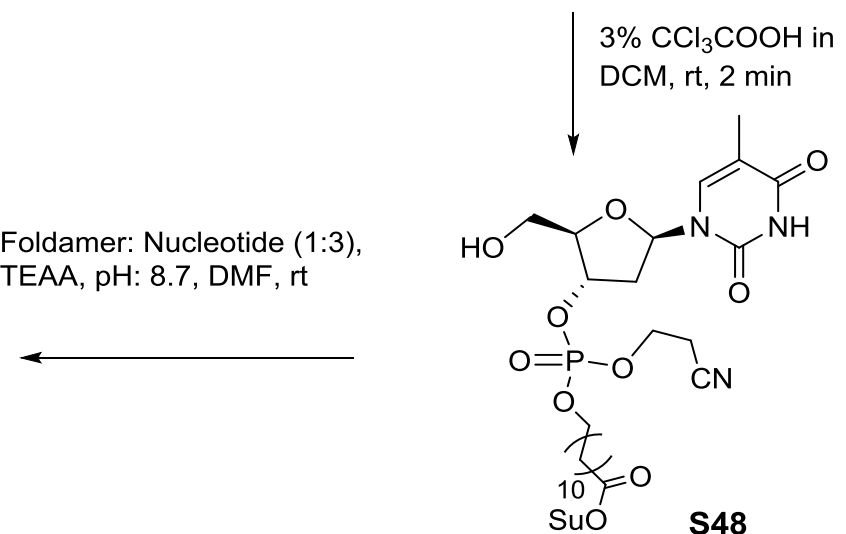

Supplementary Figure 9. Synthesis of foldamer-nucleotide conjugate, $\left({ }^{\mathrm{m}} \mathbf{Q} \mathbf{Q}^{4}\right)_{8} \mathrm{dT}$. 

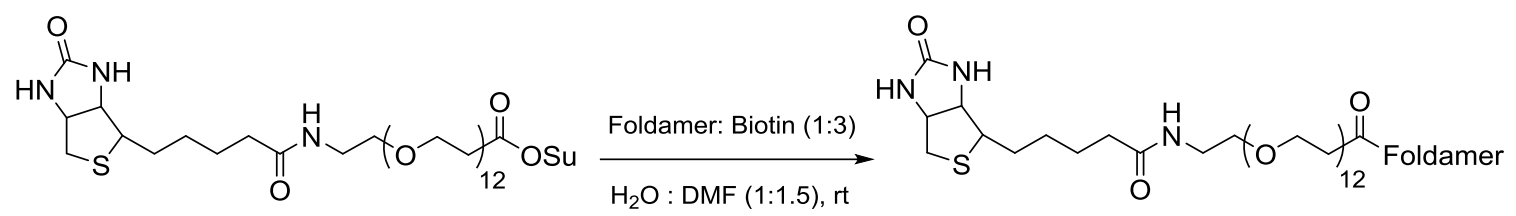

$$
\begin{aligned}
& \text { biotin- }\left({ }^{m} Q Q^{4}\right)_{4}, \mathrm{~S} 50 \\
& \text { biotin- }\left({ }^{\mathrm{m}} Q Q^{4}\right)_{8}, \mathrm{~S} 51
\end{aligned}
$$

Supplementary Figure 10. Synthesis of biotin-oligomer conjugates, biotin- $\left({ }^{\mathrm{m}} \mathbf{Q} \mathbf{Q}^{4}\right)_{4}$ and biotin$\left({ }^{\mathrm{m}} \mathbf{Q} \mathbf{Q}^{4}\right)_{8}$.<smiles>N#Cc1ccc(O)cc1</smiles>
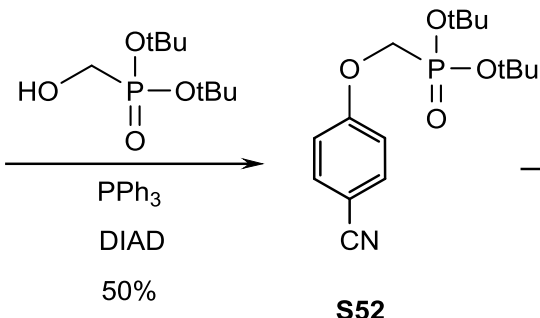

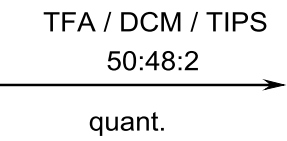

quant.<smiles>N#Cc1ccc(OCP(=O)(O)O)cc1</smiles>

S53

Supplementary Figure 11. Preparation of model phosphonate monomers S52 and S53.

\subsection{Principles of Folding}

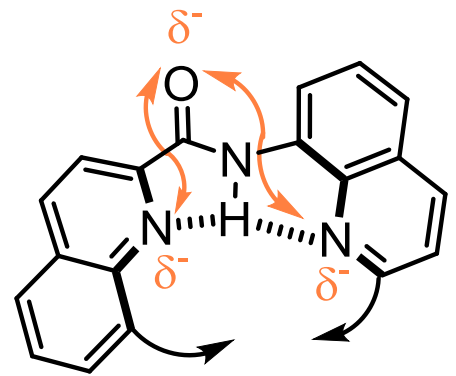

Supplementary Figure 12. Folding pattern of aza-aromatic oligoamides. Conjugation, hydrogen bonds (dashed lines) and electrostatic repulsions (double headed-arrows) concur to stabilise a preferred conformation of each aryl-amide linkages, resulting in a bent conformation that gives rise to a helix. Intramolecular $\pi-\pi$ stacking comes as an additional, solvent dependent, force stabilizing the helix. 


\subsection{Solid state X-Ray Crystallography}

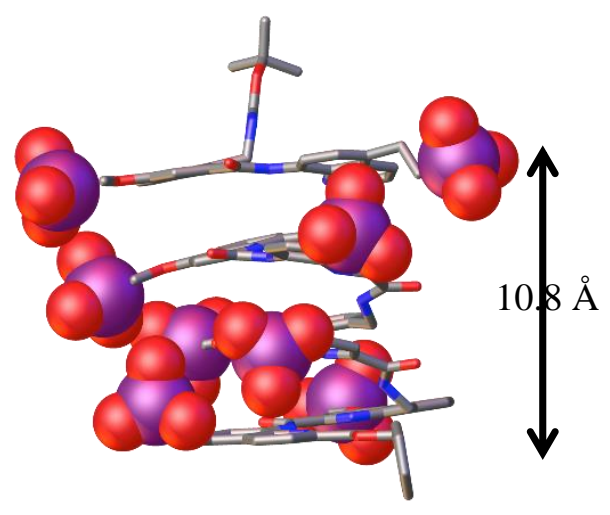

$\mathbf{a}$

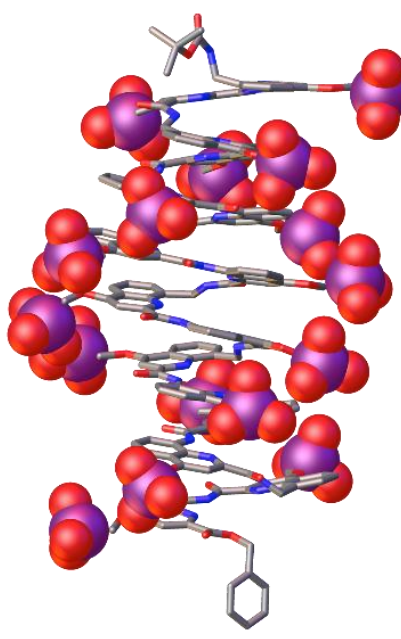

b
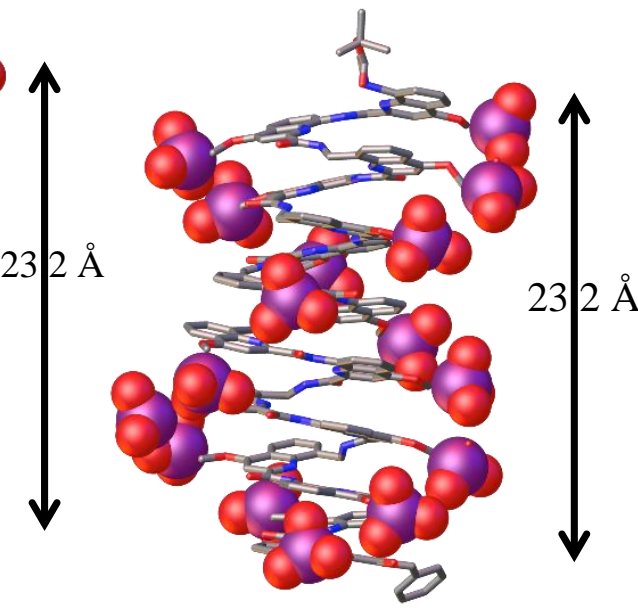

c
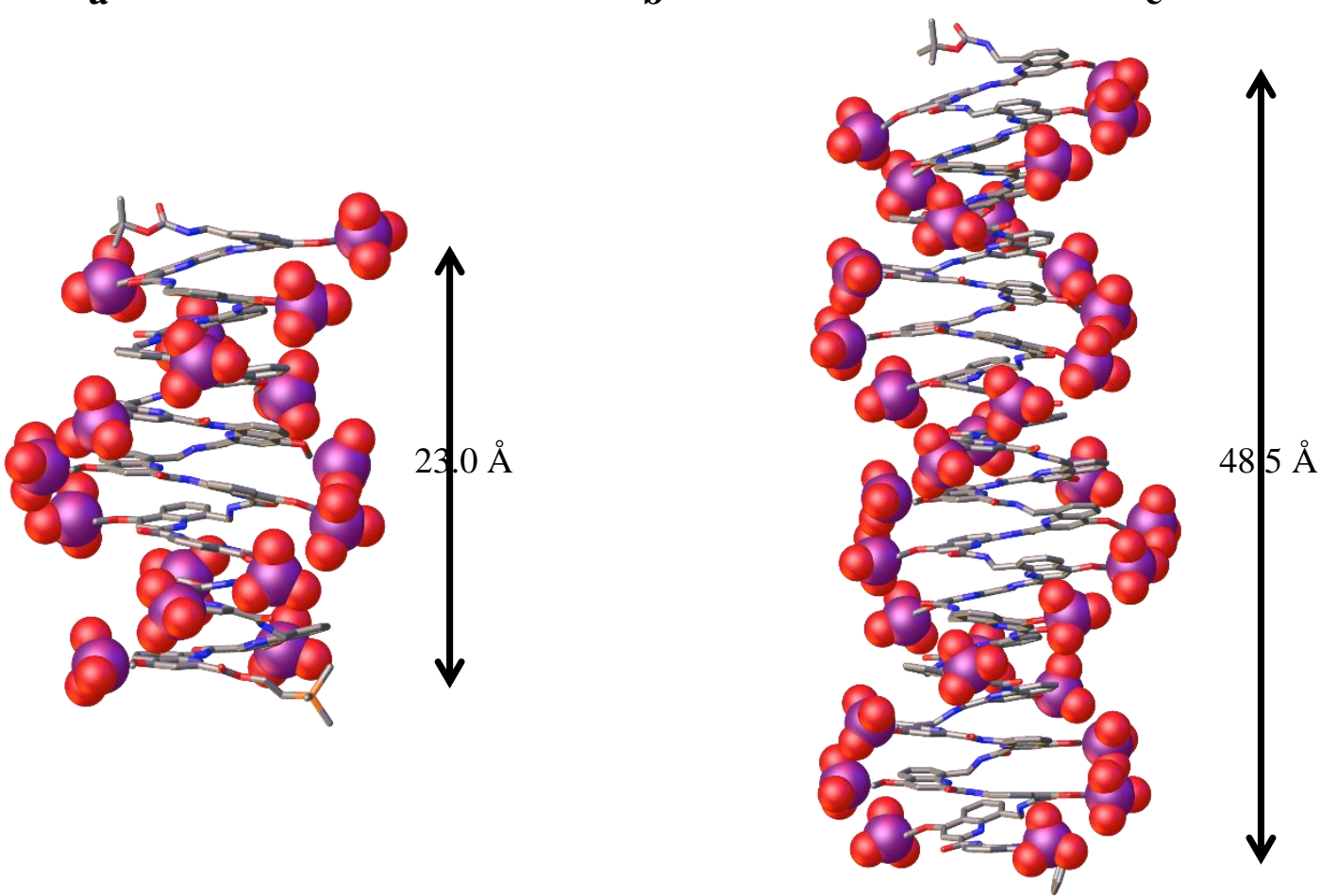

d

e

Supplementary Figure 13. Helically folded molecular structures of fully protected $\left({ }^{\mathbf{m}} \mathbf{Q Q} \mathbf{Q}^{\mathbf{x}}\right)_{\mathbf{n}}$ foldamers in the solid state as revealed by single crystal $\mathrm{x}$-ray diffraction. Main chains are shown in tube representation $($ carbon $=$ grey, oxygen $=$ red, nitrogen $=$ blue). Phosphonate groups of the side chains are shown in CPK representation (phosphorus = purple). Hydrogen atoms and ethyl groups of the phosphonate esters have been omitted for clarity. a, Boc $\left({ }^{\mathbf{m}} \mathbf{Q Q}^{5}\right)_{4} \mathrm{OBn}(\mathbf{S 4 2})$. b, the first independent molecule of the structure of $\operatorname{Boc}\left({ }^{m} \mathbf{Q Q}^{4}\right)_{8} \mathrm{OBn}(\mathbf{S 3 1})$. c, the second independent molecule of $\operatorname{Boc}\left({ }^{\mathrm{m}} \mathbf{Q Q}{ }^{4}\right)_{8} \mathrm{OBn}(\mathbf{S 3 1})$. d, Boc $\left({ }^{\mathrm{m}} \mathbf{Q} \mathbf{Q}^{4}\right)_{8} \mathrm{TMSE}$. e, Boc $\left({ }^{\mathrm{m}} \mathbf{Q} \mathbf{Q}^{4}\right)_{16} \mathrm{OBn}(\mathbf{S 3 5})$. The structures show a slight stretching of the helices in the solid state as length increases. For example, the $\left({ }^{\mathrm{m}} \mathbf{Q Q}{ }^{4}\right)_{16}$ helix is a little longer than twice the length of $\left({ }^{\mathrm{m}} \mathbf{Q} \mathbf{Q}^{4}\right)_{\mathbf{8}}$. 


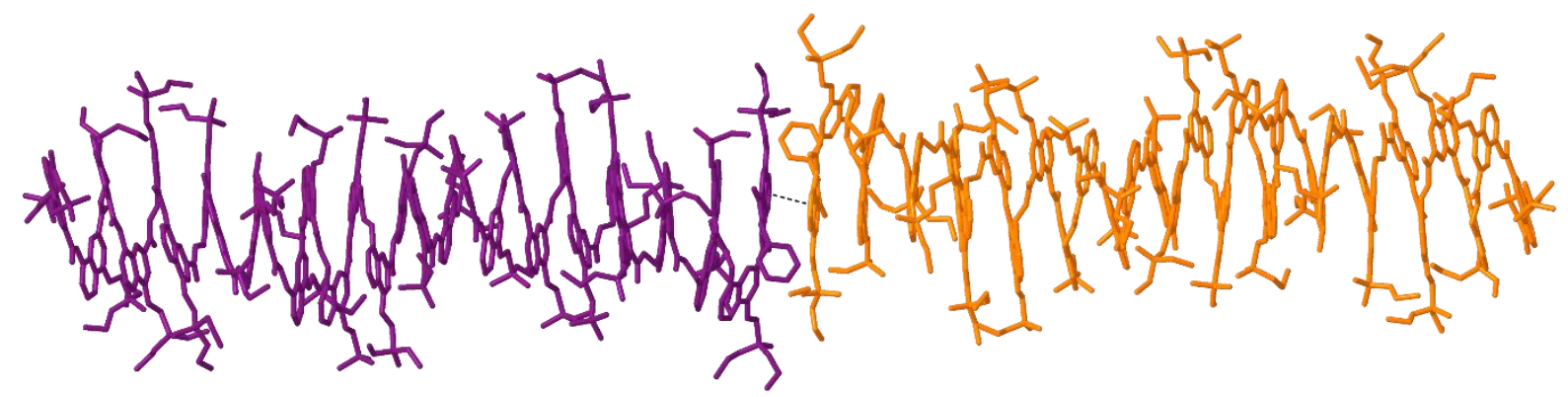

a

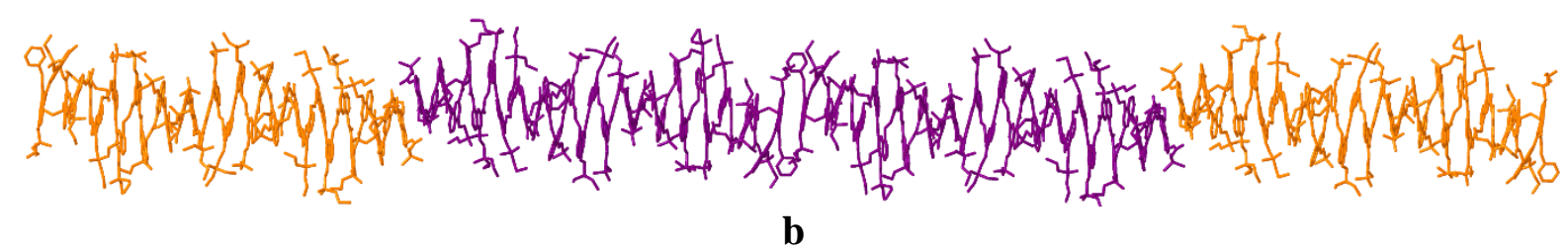

Supplementary Figure 14. Packing of fully protected $\operatorname{Boc}\left({ }^{\mathrm{m}} \mathbf{Q Q}^{4}\right)_{16} \mathrm{OBn}(\mathbf{S 3 5})$ in the solid state showing the linear arrangement of contiguous helices. a, Head-to-head $\pi-\pi$ stacking of the Cterminal rings of two fully protected $\operatorname{Boc}\left({ }^{\mathrm{m}} \mathbf{Q Q}^{4}\right)_{16} \mathrm{OBn}$ helices (inter-aromatic distance $=3.32 \AA$ ). b, Linear array of four helices. Contacts between helices at their $N$-termini involve $\pi-\pi$ stacking and hydrogen bonding between the carbamate $\mathrm{NH}$ protons of each helix and an amide carbonyl of the other helix. Helix handedness inverts at each helix-helix contact. 


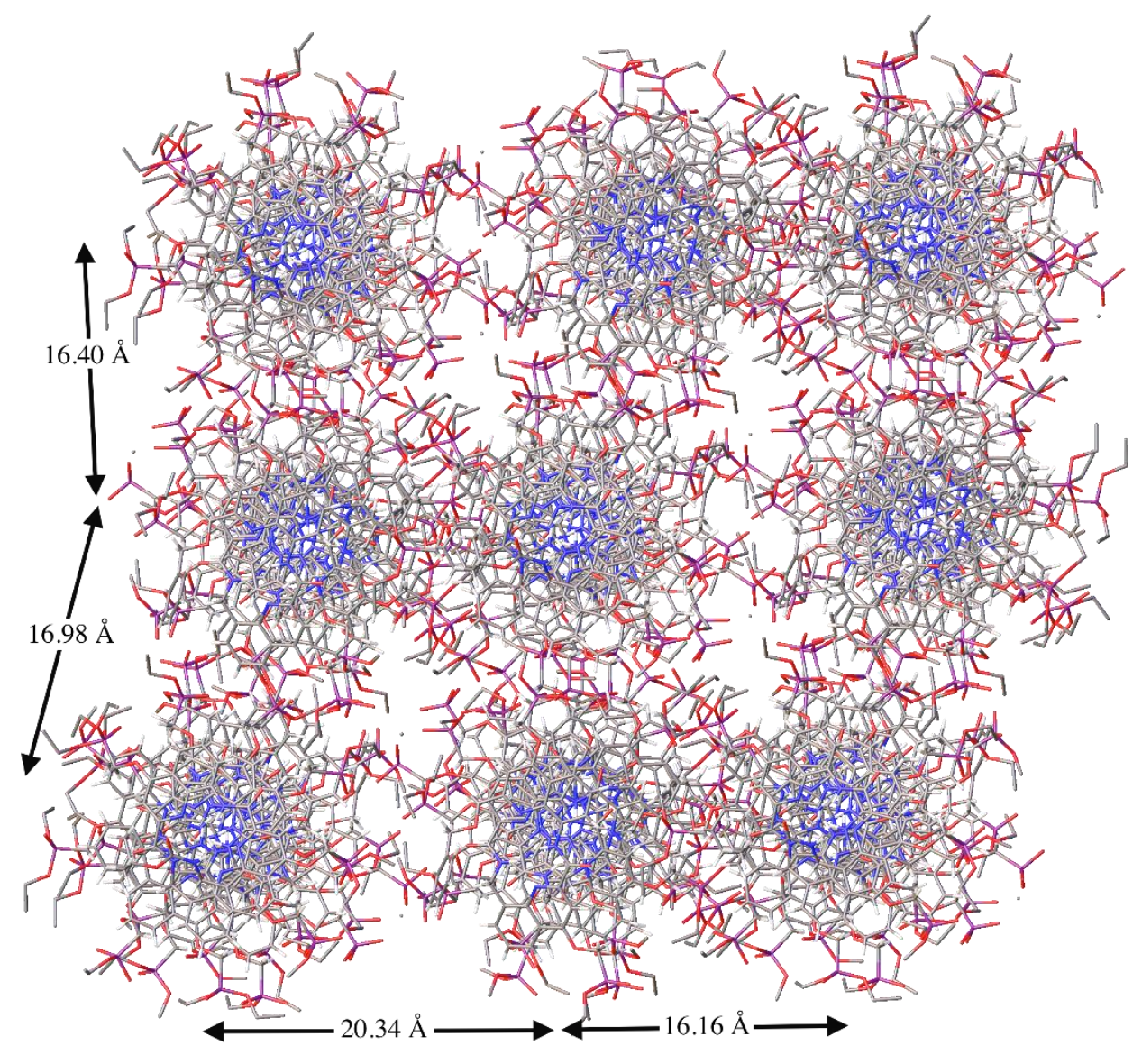

Supplementary Figure 15. Packing of fully protected $\operatorname{Boc}\left({ }^{m} \mathbf{Q Q}^{4}\right)_{16} \mathrm{OBn}(\mathbf{S 3 5})$ in the crystal viewed along the [ $\left.\begin{array}{lll}1 & 1 & 2\end{array}\right]$ direction showing the planar arrangement of the rod-like helices. Distances are between the helix axes of neighbor helices in the packing.

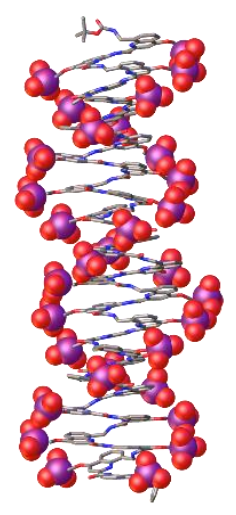

$\mathbf{a}$

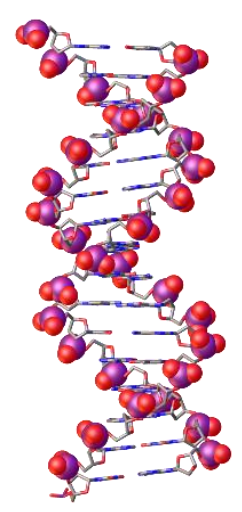

b

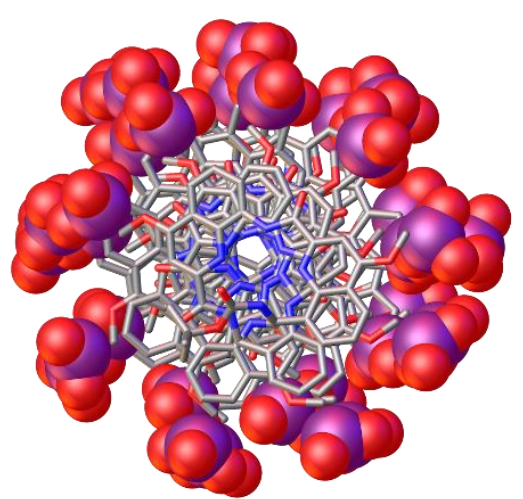

c

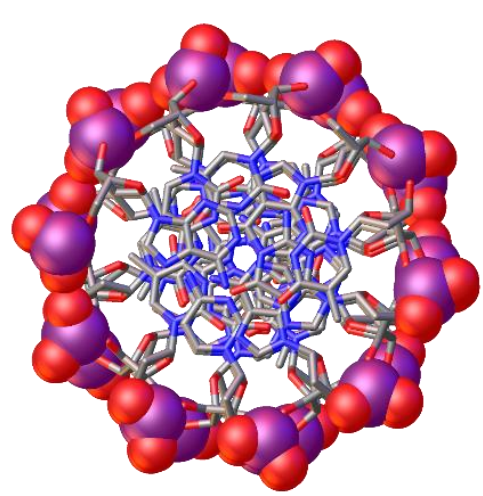

d

Supplementary Figure 16. Side-by-side comparison of the structure of fully protected $\operatorname{Boc}\left({ }^{\mathrm{m}} \mathbf{Q Q}{ }^{4}\right)_{16} \mathbf{O B n}(\mathbf{S 3 5})(\mathbf{a}, \mathbf{c})$ and of an idealised 16-base pair B-DNA (b,d) shown at the same scale. $\mathbf{a}, \mathbf{b}$ side views; $\mathbf{c}, \mathbf{d}$ top views. 

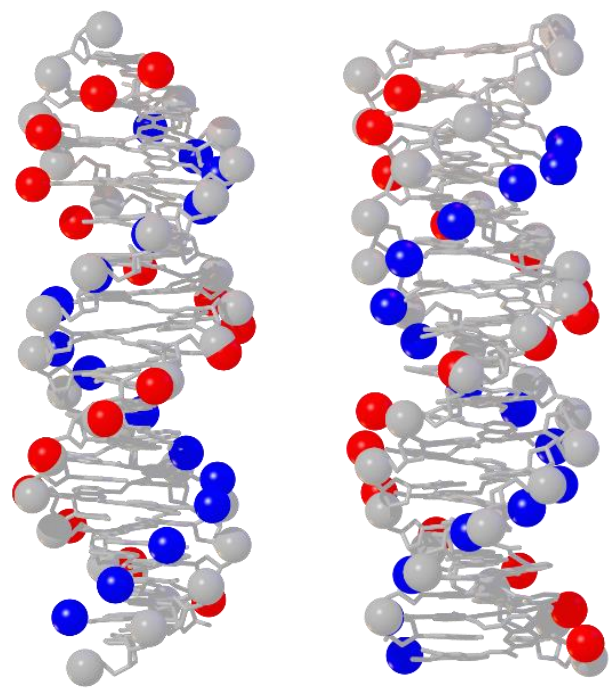

Supplementary Figure 17. Overlays of the crystal structure of fully protected $\operatorname{Boc}\left({ }^{\mathbf{m}} \mathbf{Q Q}{ }^{4}\right)_{16} \mathrm{OBn}(\mathbf{S 3 5})$ with 16-base pair B-DNA. a, Overlay minimizing the distances between all $32{ }^{\mathrm{m}} \mathrm{Q}$ and $\mathrm{Q}^{4}$ phosphorus atoms (shown as red spheres and blue spheres, respectively), and the corresponding phosphorus atoms in DNA (grey spheres). The RMSD is $2.840 \AA$ and the maximum deviation observed between two phosphorous atom positions is $5.836 \AA$. This figure shows a good match in the centre of the sequence and an increasing mismatch towards the ends. b, Overlay minimizing the distances between the $16{ }^{\mathrm{m}} \mathrm{Q}$ phosphorus atoms (red spheres) and the corresponding 16 phosphorus atoms in DNA (grey spheres). The figure shows that the phosphorus atoms of $\mathrm{Q}^{4}$ units (blue spheres) lie in the major groove of DNA as a consequence of groove width mismatch between the two structures.

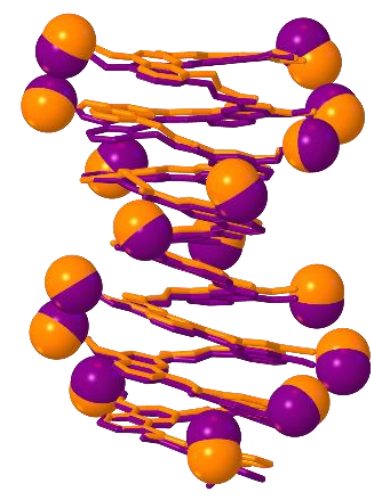

a

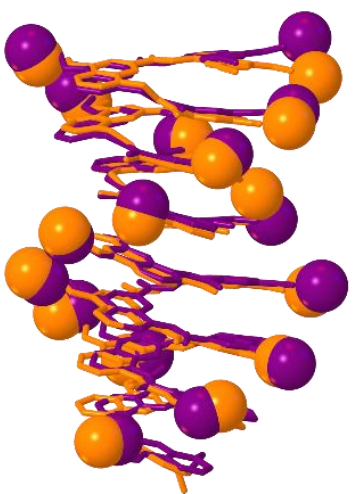

b

Supplementary Figure 18. Overlay of the x-ray structures of $\left({ }^{\mathbf{m}} \mathbf{Q} \mathbf{Q}^{4}\right)_{\mathrm{n}}$ foldamers showing structure variations (see Table S6 for RSMD values). a, Overlay the N-terminal segment of fully protected Boc $\left({ }^{\mathbf{m}} \mathbf{Q} \mathbf{Q}^{4}\right)_{16} \mathrm{OBn}(\mathbf{S 3 5})$ with the structure of fully protected $\mathrm{Boc}\left({ }^{\mathrm{m}} \mathbf{Q} \mathbf{Q}^{\mathbf{4}}\right)_{8} \mathrm{TMSE}$ showing a good match. b, Overlay of the C-terminal segment of fully protected $\mathrm{Boc}\left({ }^{\mathrm{m}} \mathbf{Q} \mathbf{Q}^{4}\right)_{16} \mathrm{OBn}$ and one of the two independent molecules of the structure of fully protected $\operatorname{Boc}\left({ }^{\mathrm{m}} \mathbf{Q} \mathbf{Q}^{4}\right)_{8} \mathrm{OBn}(\mathbf{S 3 1})$ showing significant differences between the two structures and highlighting conformational variations available to the foldamers. Phosphorus atoms are shown as spheres. Other parts of the molecules are shown in tube representation. 


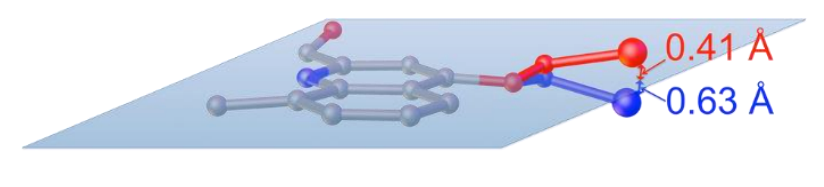

a

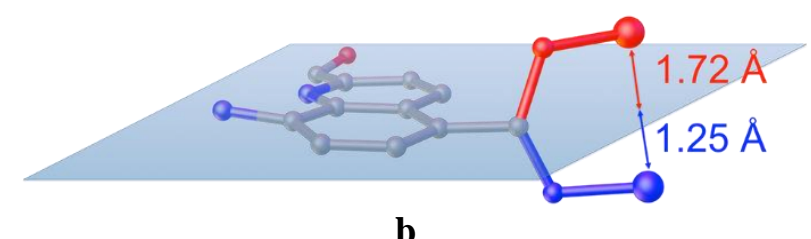

b

Supplementary Figure 19. Variations of the position of phosphonate groups in the crystal structure of fully protected $\mathrm{Boc}\left({ }^{\mathrm{m}} \mathbf{Q} \mathbf{Q}^{5}\right)_{4} \mathrm{OBn}(\mathbf{S 4 2})$. a, Largest observed deviations of the phosphorous atom of side chains in position 4 of ${ }^{\mathrm{m}} \mathrm{Q}$ monomers above and below the plane of quinoline rings. $\mathbf{b}$, Largest observed deviations of the phosphorous atom of side chains in position 5 of $\mathrm{Q}^{5}$ monomers above and below the plane of quinoline rings. The noticeable difference between ${ }^{\mathrm{m}} \mathrm{Q}$ and $\mathrm{Q}^{5}$ monomers arises from the different connecting groups $\left(-\mathrm{OCH}_{2}-\right.$ vs. $\left.-\mathrm{CH}_{2} \mathrm{CH}_{2}\right)$ between phosphonates and quinoline rings. For ${ }^{\mathrm{m}} \mathrm{Q}$ monomers $\left(-\mathrm{OCH}_{2}\right.$-connection), an ether oxygen in position 4 consistently favors a coplanar arrangement in which the side chain methylene is found in or near the plane of the quinoline ring. This conformation is disfavored in $\mathrm{Q}^{5}$ monomers ($\mathrm{CH}_{2} \mathrm{CH}_{2}$ - connection), as it would result in a steric clash between methylene protons and the aryl proton in position 4. Consequently, side chains of $\mathrm{Q}^{5}$ monomers extend out of the plane of quinoline rings. 


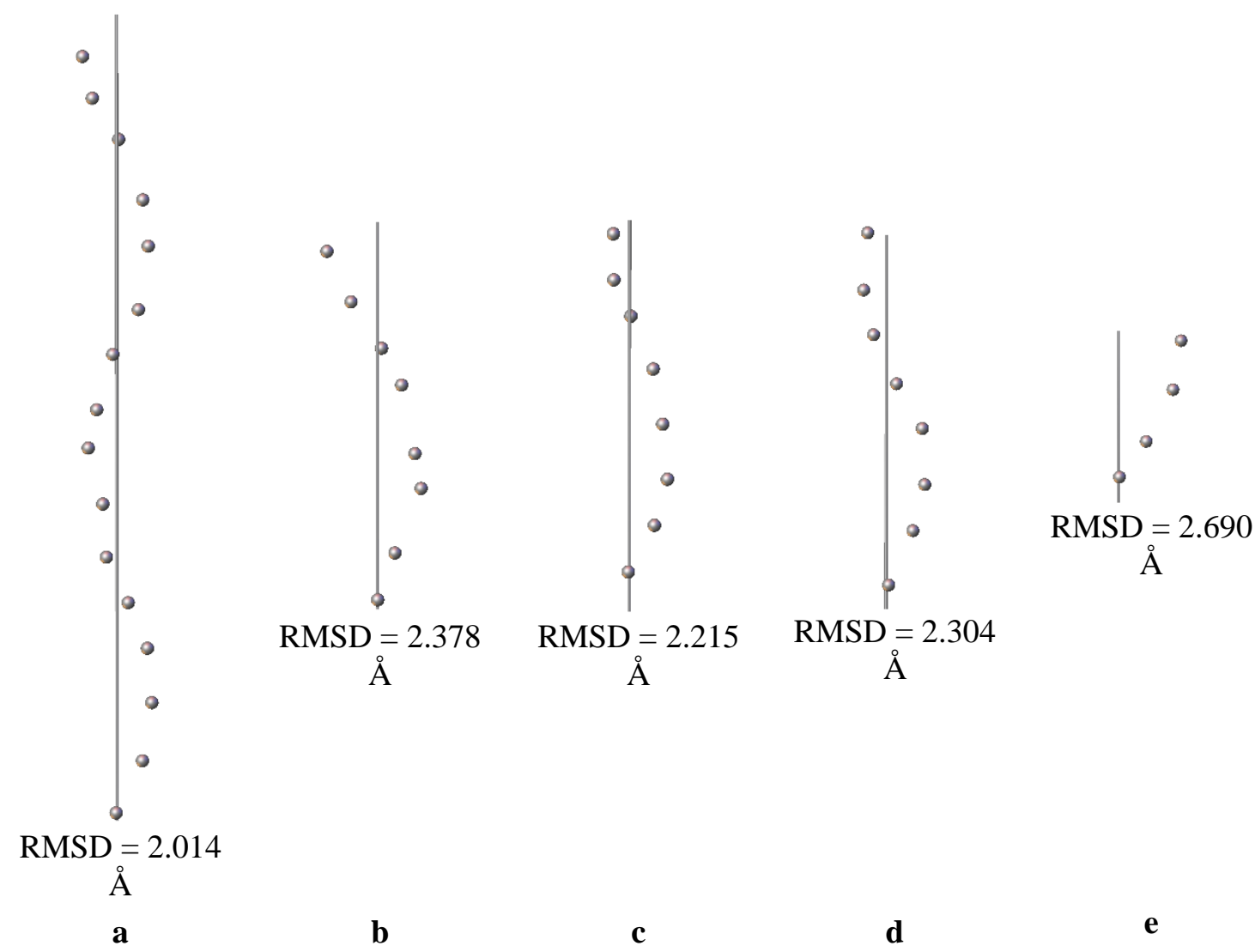

Supplementary Figure 20. Oscillation of the foldamer backbones around the helix axis in crystal structures. The helix axis is represented as the best line through the nitrogen atoms of the backbone. Grey spheres correspond to the centroids between pairs of adjacent phosphorus atoms. a, In $\operatorname{Boc}\left({ }^{\mathbf{m}} \mathbf{Q Q}{ }^{\mathbf{4}}\right)_{16} \mathrm{OBn}(\mathbf{S 3 5})$ about 10 phosphorus pairs span a helix turn. $\mathbf{b}$, in the first independent molecule of $\mathrm{Boc}\left({ }^{\mathbf{m}} \mathbf{Q Q}{ }^{4}\right)_{8} \mathrm{OBn}(\mathbf{S 3 1})$, about 12 phosphorus pairs span a helix turn. $\mathbf{c}$, in the second independent molecule of $\operatorname{Boc}\left({ }^{\mathbf{m}} \mathbf{Q Q}^{\mathbf{4}}\right)_{8} \mathrm{OBn}(\mathbf{S 3 1})$, about 12 phosphorus pairs span a helix turn. $\mathbf{d}$, in $\operatorname{Boc}\left({ }^{\mathbf{m}} \mathbf{Q Q}^{4}\right)_{8}$ TMSE, about 10 phosphorus pairs span a helix turn. e, in Boc $\left({ }^{\mathrm{m}} \mathrm{QQ}^{5}\right)_{4} \mathrm{OBn}(\mathbf{S 4 2})$. RMSD values are defined as the root mean square deviation of the centroids position from the foldamer axis. The shorter RMSD value and fewer units per turn in the case of $\operatorname{Boc}\left({ }^{\mathbf{m}} \mathbf{Q Q}^{4}\right)_{16} \mathrm{OBn}$ (S35) reflects a slight elongation (stretching) of this helix as compared to the others. 


\subsection{Solution spectroscopic structural analysis}

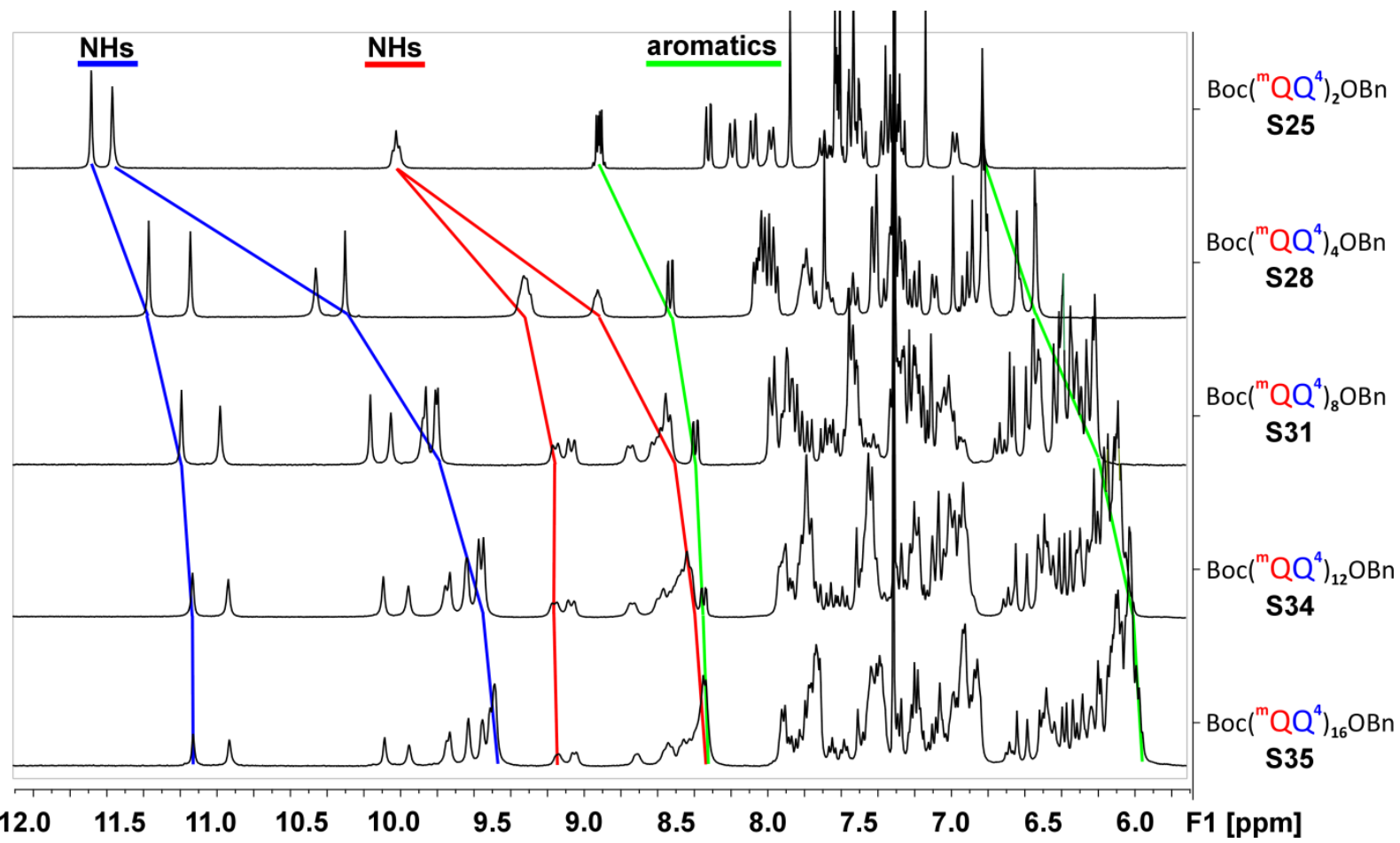

Supplementary Figure 21. Parts of ${ }^{1} \mathrm{H}$ NMR spectra of fully protected $\mathrm{Boc}\left({ }^{\mathrm{m}} \mathrm{QQ}^{4}\right)_{2} \mathrm{OBn}$, $\operatorname{Boc}\left({ }^{\mathrm{m}} \mathrm{QQ}^{4}\right)_{4} \mathrm{OBn}$, Boc $\left({ }^{\mathrm{m}} \mathrm{QQ}^{4}\right)_{8} \mathrm{OBn}$, Boc $\left({ }^{\mathrm{m}} \mathrm{QQ}^{4}\right)_{12} \mathrm{OBn}(300 \mathrm{MHz})$ and $\operatorname{Boc}\left({ }^{\mathrm{m}} \mathrm{QQ}^{4}\right)_{16} \mathrm{OBn}(400$ $\mathrm{MHz}$ ), all recorded in $\mathrm{CDCl}_{3}$. As an indication of folding, signals are spread over a wide chemical shift range despite the repetitive nature of the sequences. Upfield shifts resulting from ring current effects associated with intramolecular $\pi-\pi$ stacking are more pronounced as helix length increases. The blue red and green lines delineate the chemical shift range of aromatic amine amide protons, aliphatic amine amide protons and aromatic protons, respectively. 


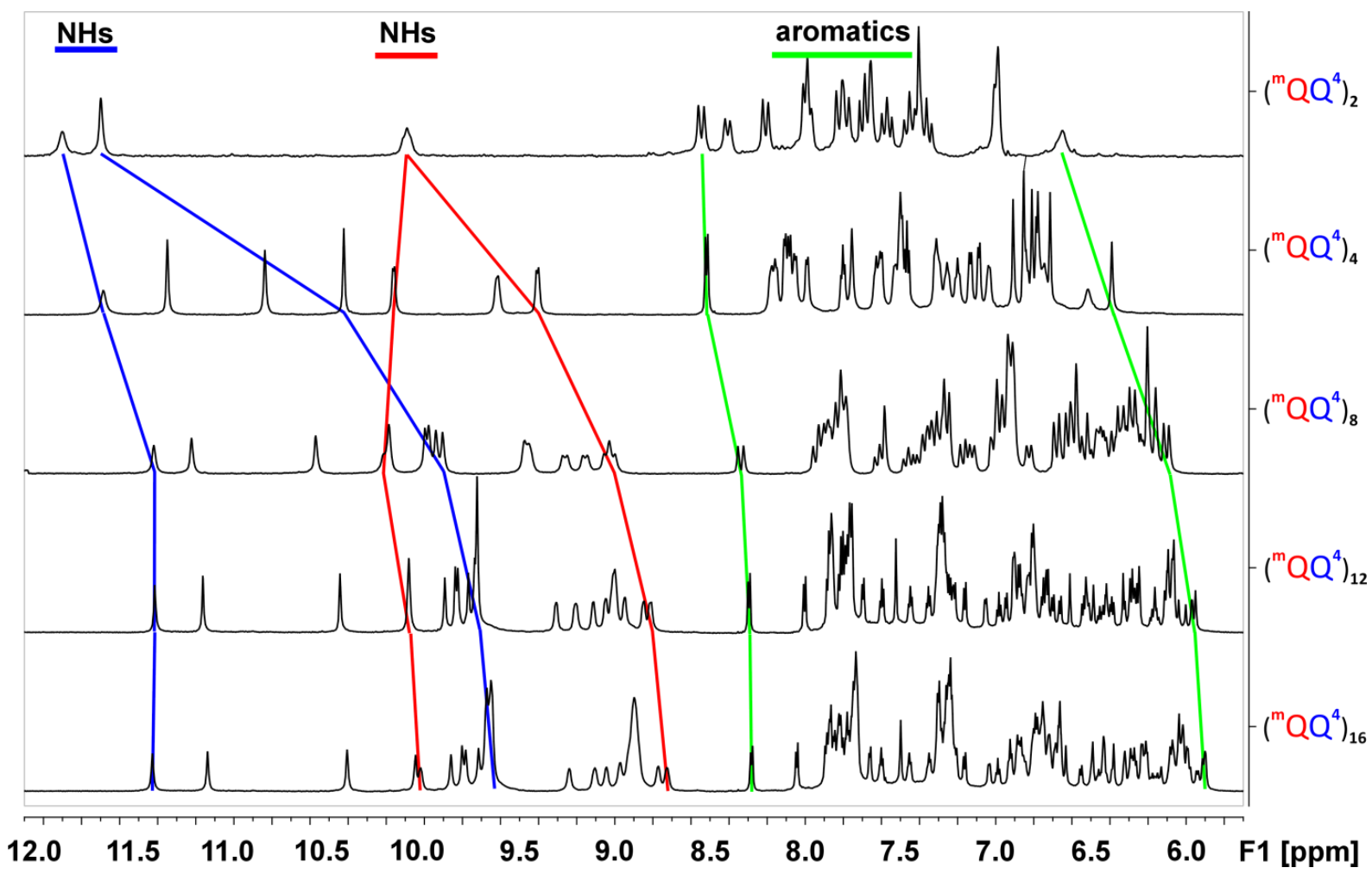

Supplementary Figure 22. Parts of ${ }^{1} \mathrm{H}$ NMR spectra of deprotected $\left({ }^{\mathrm{m}} \mathrm{QQ}^{4}\right)_{2}(300 \mathrm{MHz}),\left({ }^{\mathrm{m}} \mathrm{QQ}^{4}\right)_{4}$ $(700 \mathrm{MHz}),\left({ }^{\mathrm{m}} \mathrm{QQ}^{4}\right)_{8}(300 \mathrm{MHz}),\left({ }^{\mathrm{m}} \mathrm{QQ}^{4}\right)_{12}(700 \mathrm{MHz})$ and $\left({ }^{\mathrm{m}} \mathrm{QQ}^{4}\right)_{16}(700 \mathrm{MHz})$ all recorded at 2 $\mathrm{mM}$ in $50 \mathrm{mM}$ ammonium bicarbonate $\mathrm{H}_{2} \mathrm{O} / \mathrm{D}_{2} \mathrm{O}(9: 1 \mathrm{vol} / \mathrm{vol})$. As an indication of folding, signals are spread over a wide chemical shift range despite the repetitive nature of the sequences. Upfield shifts resulting from ring current effects associated with intramolecular $\pi-\pi$ stacking are more pronounced as helix length increases. Blue lines, red lines and green lines indicate the chemical range in which aromatic amine amide, aliphatic amine amide and aromatic protons are found, respectively. 

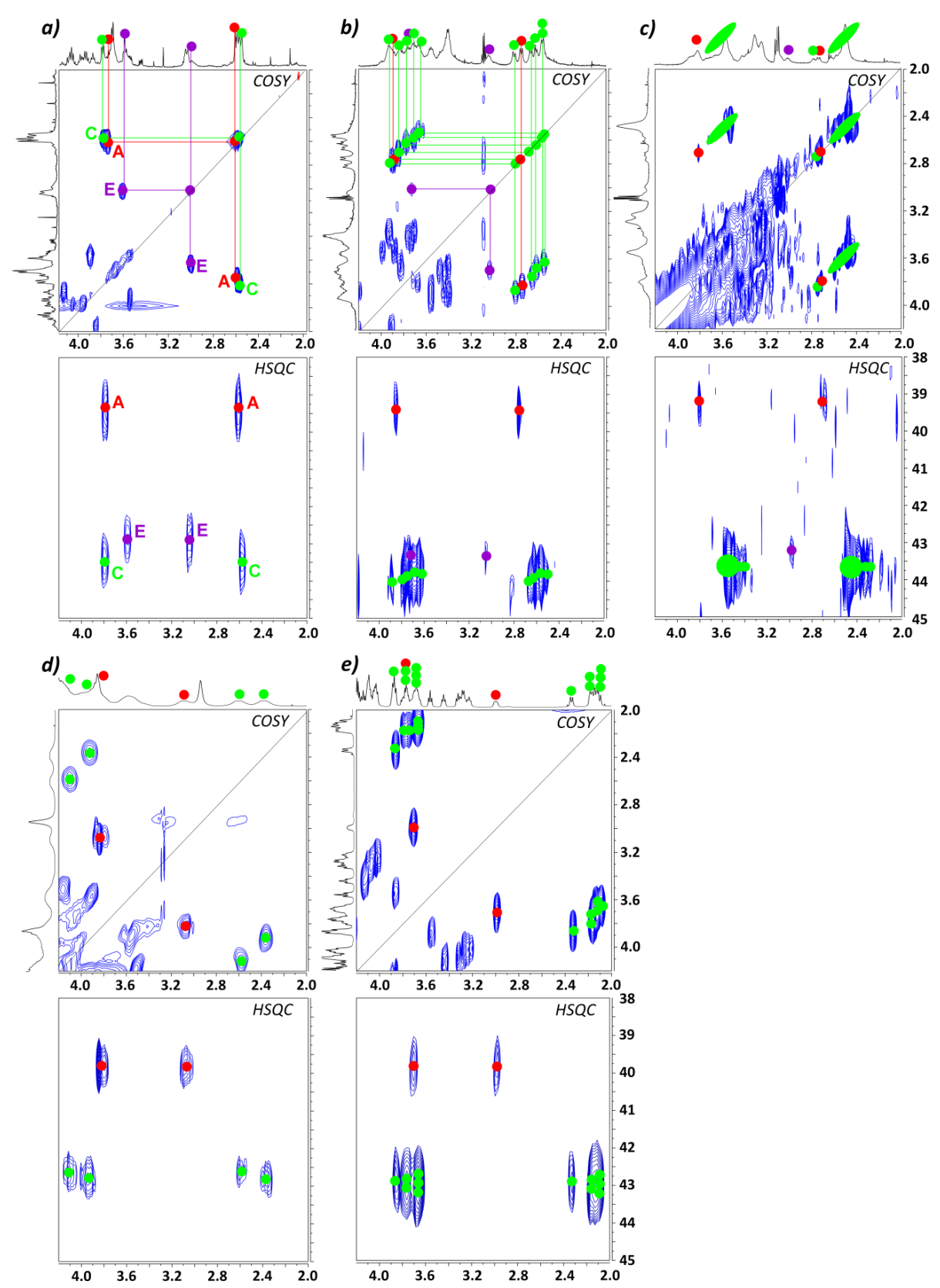

Supplementary Figure 23. Excerpts of ${ }^{1} \mathrm{H}-{ }^{1} \mathrm{H}$ COSY and ${ }^{1} \mathrm{H}^{13} \mathrm{C}$ HSQC NMR spectra of a) $\left({ }^{\mathrm{m}} \mathrm{QQ}^{4}\right)_{4}$; b) $\left.\left({ }^{\mathrm{m}} \mathrm{QQ}^{4}\right)_{8} ; \mathrm{c}\right)\left({ }^{\mathrm{m}} \mathrm{QQ}^{4}\right)_{16}$; d) fully protected $\mathrm{Boc}\left({ }^{\mathrm{m}} \mathrm{QQ}^{4}\right)_{4} \mathrm{OBn}(\mathbf{S 2 8})$; and e) fully protected Boc $\left({ }^{\mathrm{m}} \mathrm{QQ}^{4}\right)_{8} \mathrm{OBn}(\mathbf{S 3 1})$. Spectra in a), b) and c) were recorded in $50 \mathrm{mM}$ ammonium bicarbonate $\mathrm{H}_{2} \mathrm{O} / \mathrm{D}_{2} \mathrm{O}(9: 1 \mathrm{vol} / \mathrm{vol})$. Spectra in d) and e) were recorded in $\mathrm{CDCl}_{3}$. In all cases diagonal suppression was applied. The spectra show strong anisochronicity of main chain benzylic $\left(\mathrm{CH}_{2}-\right.$ aryl) protons of ${ }^{\mathrm{m}} \mathrm{Q}$ monomers, marked with coloured circles, in helical conformations. Full assignment was carried out only for $\left({ }^{\mathrm{m}} \mathrm{QQ}^{4}\right)_{4}$ (a). Based on ${ }^{13} \mathrm{C}$ chemical shift values in HSQC spectra, red dots can be assigned to the N-terminal benzylic position. The purple circles belong to the second ${ }^{\mathrm{m}} \mathrm{Q}$ monomer from the C-terminus (ring $\mathrm{E}$ in $\left.\left({ }^{\mathrm{m}} \mathrm{QQ}^{4}\right)_{4}\right)$. Benzylic protons of the first ${ }^{\mathrm{m}} \mathrm{Q}$ monomer from the C-terminus (ring $\mathrm{G}$ in $\left.\left({ }^{\mathrm{m}} \mathrm{QQ}^{4}\right)_{4}\right)$ do not show strong anisochronicity and are not labelled here (see supplementary Fig. 25, bottom part). Other benzylic protons are marked with green circles. 


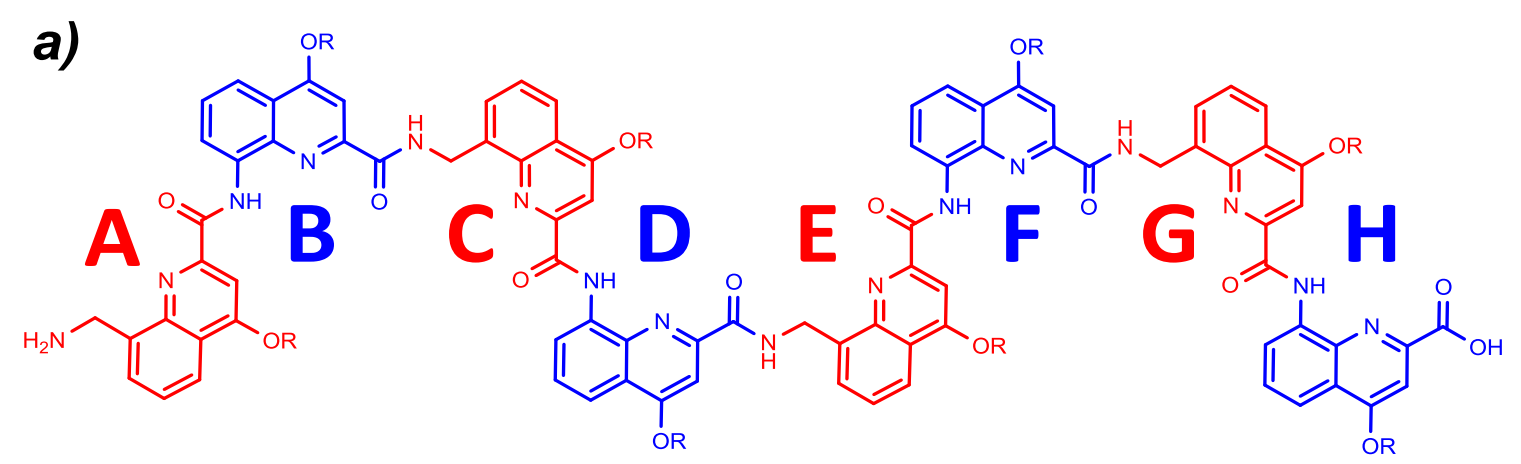

b)
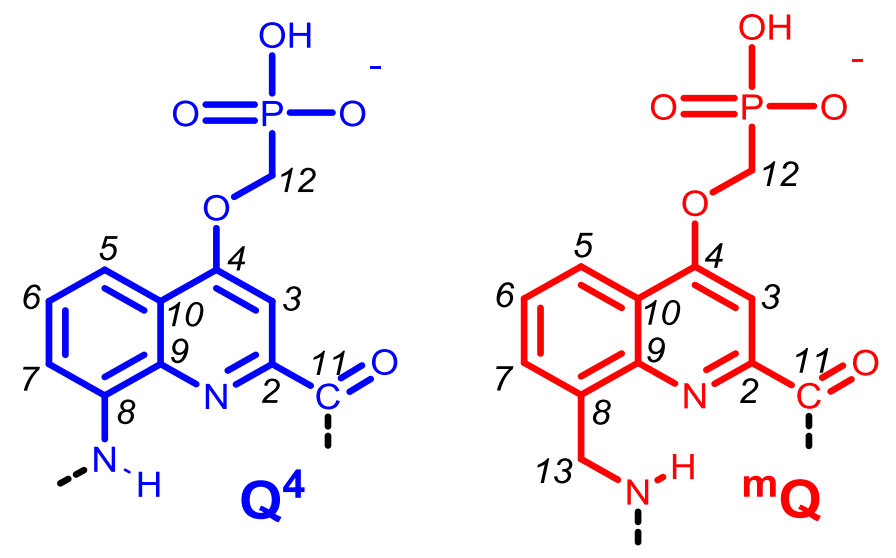

Supplementary Figure 24. Labelling conventions of the structure of $\left({ }^{\mathrm{m}} \mathrm{QQ}^{4}\right)_{4}$ used for assigning NMR spectra: a) monomer lettering convention from $\mathrm{A}$ to $\mathrm{H}$ starting from the N-terminus (note that in the main text rings $\mathrm{A}, \mathrm{B}, \ldots, \mathrm{H}$ are coded with numbers $1,2, \ldots, 8)$; b) atom numbering. 


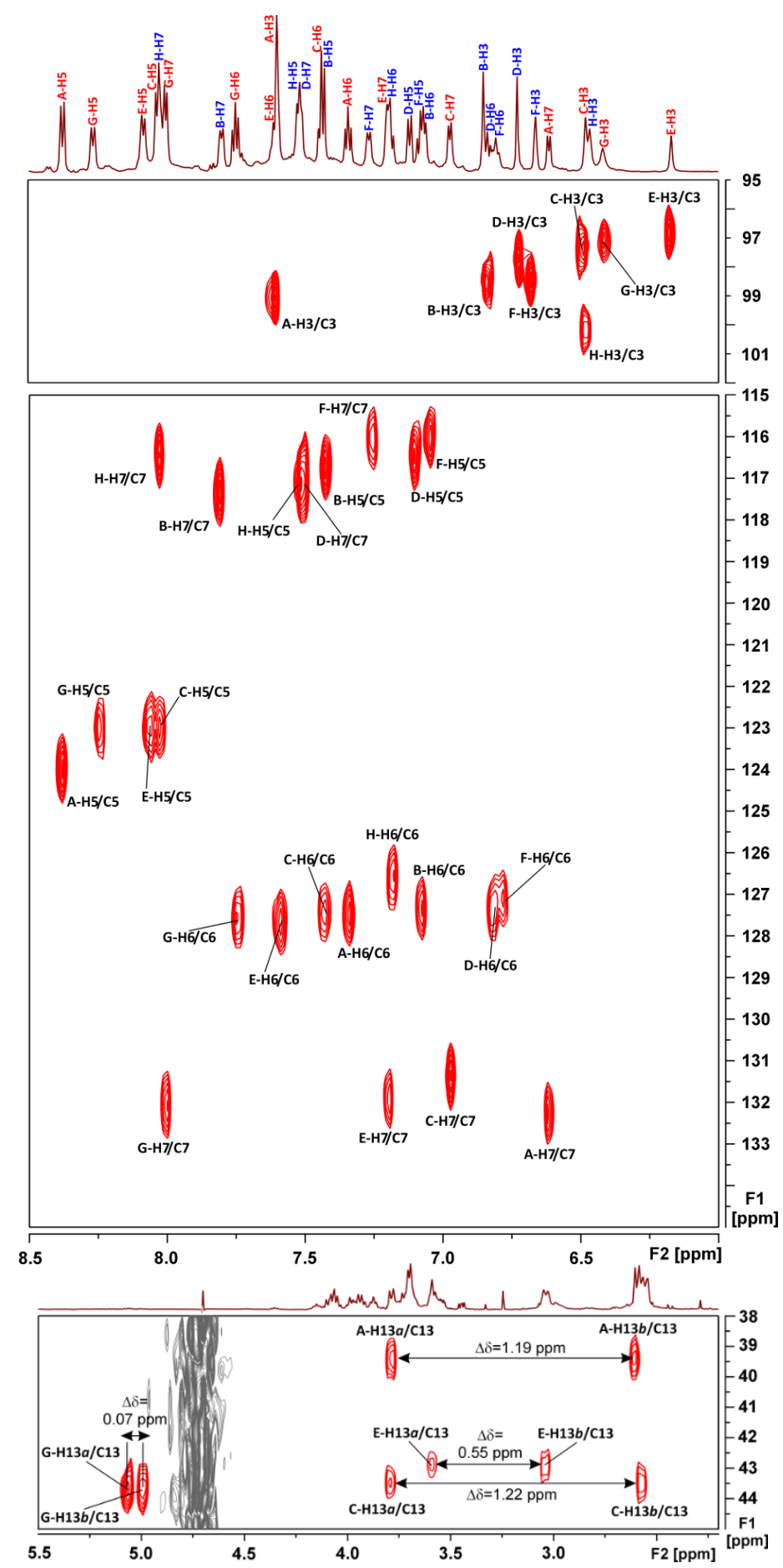

Supplementary Figure 25. Excerpts of the $700 \mathrm{MHz} H S Q C$ spectrum of $\left({ }^{\mathrm{m}} \mathrm{QQ}^{4}\right)_{4}$ recorded at 2 $\mathrm{mM}$ in $50 \mathrm{mM}$ ammonium bicarbonate $\mathrm{H}_{2} \mathrm{O} / \mathrm{D}_{2} \mathrm{O}(9: 1 \mathrm{vol} / \mathrm{vol})$ showing ${ }^{1} \mathrm{H}_{-}{ }^{13} \mathrm{C}$ correlations of aromatic protons. 


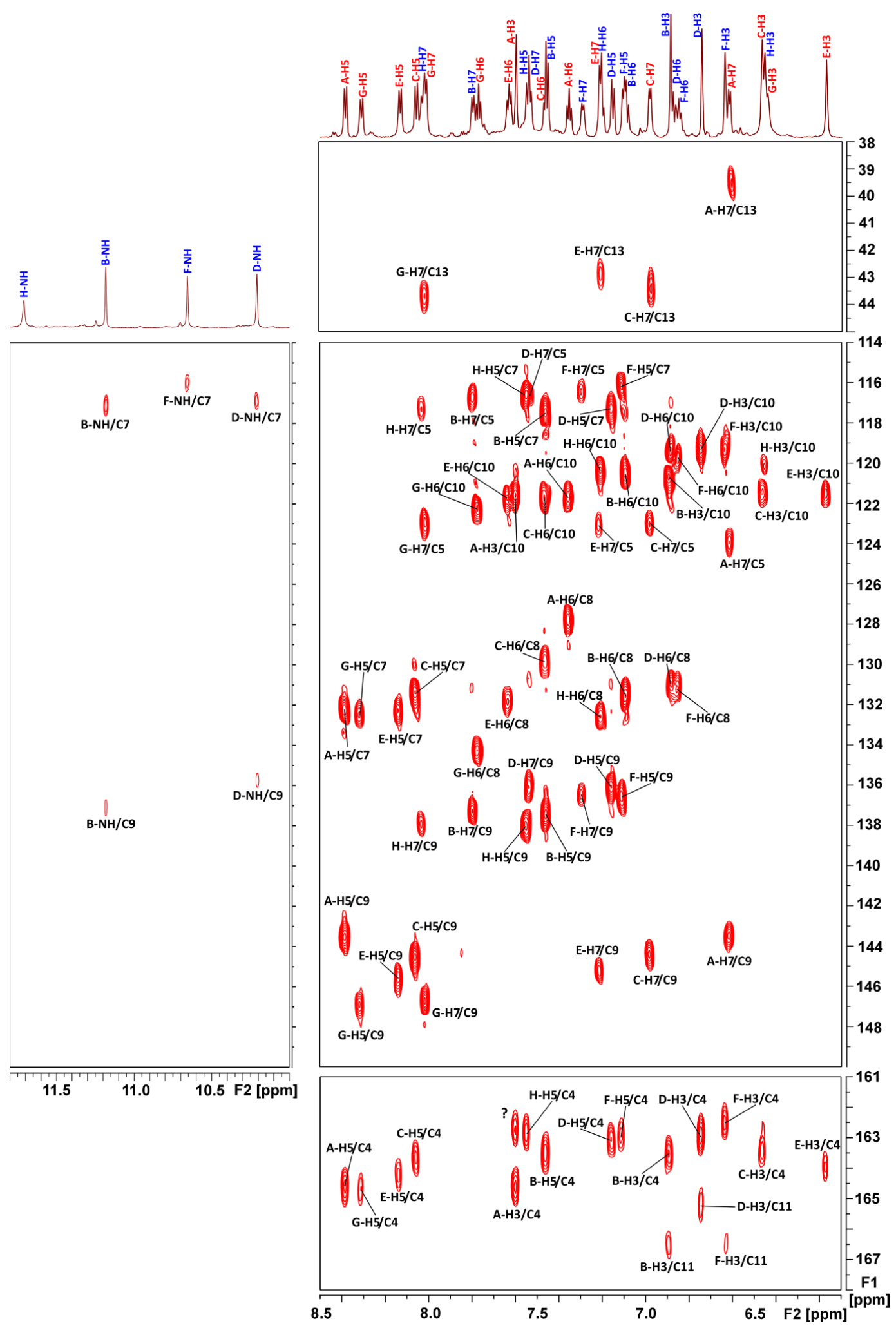

Supplementary Figure 26. Parts of $700 \mathrm{MHz} H M B C$ spectrum of $\left({ }^{\mathrm{m}} \mathrm{QQ}^{4}\right)_{4}$ recorded at $2 \mathrm{mM}$ in $50 \mathrm{mM}$ ammonium bicarbonate $\mathrm{H}_{2} \mathrm{O} / \mathrm{D}_{2} \mathrm{O}(9: 1 \mathrm{vol} / \mathrm{vol})$ showing ${ }^{1} \mathrm{H}_{-}{ }^{13} \mathrm{C}$ correlations essential to the full assignment of the spectra. 

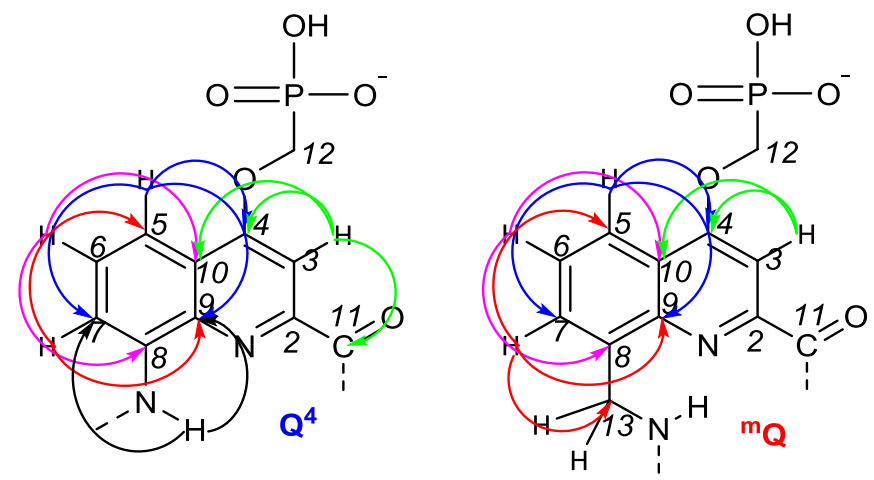

Supplementary Figure 27. Graphical representation of $\mathrm{HMBC}{ }^{1} \mathrm{H}-{ }^{13} \mathrm{C}$ correlations used for the assignment of the spectra of $\left({ }^{\mathrm{m}} \mathrm{QQ}^{4}\right)_{4}$.

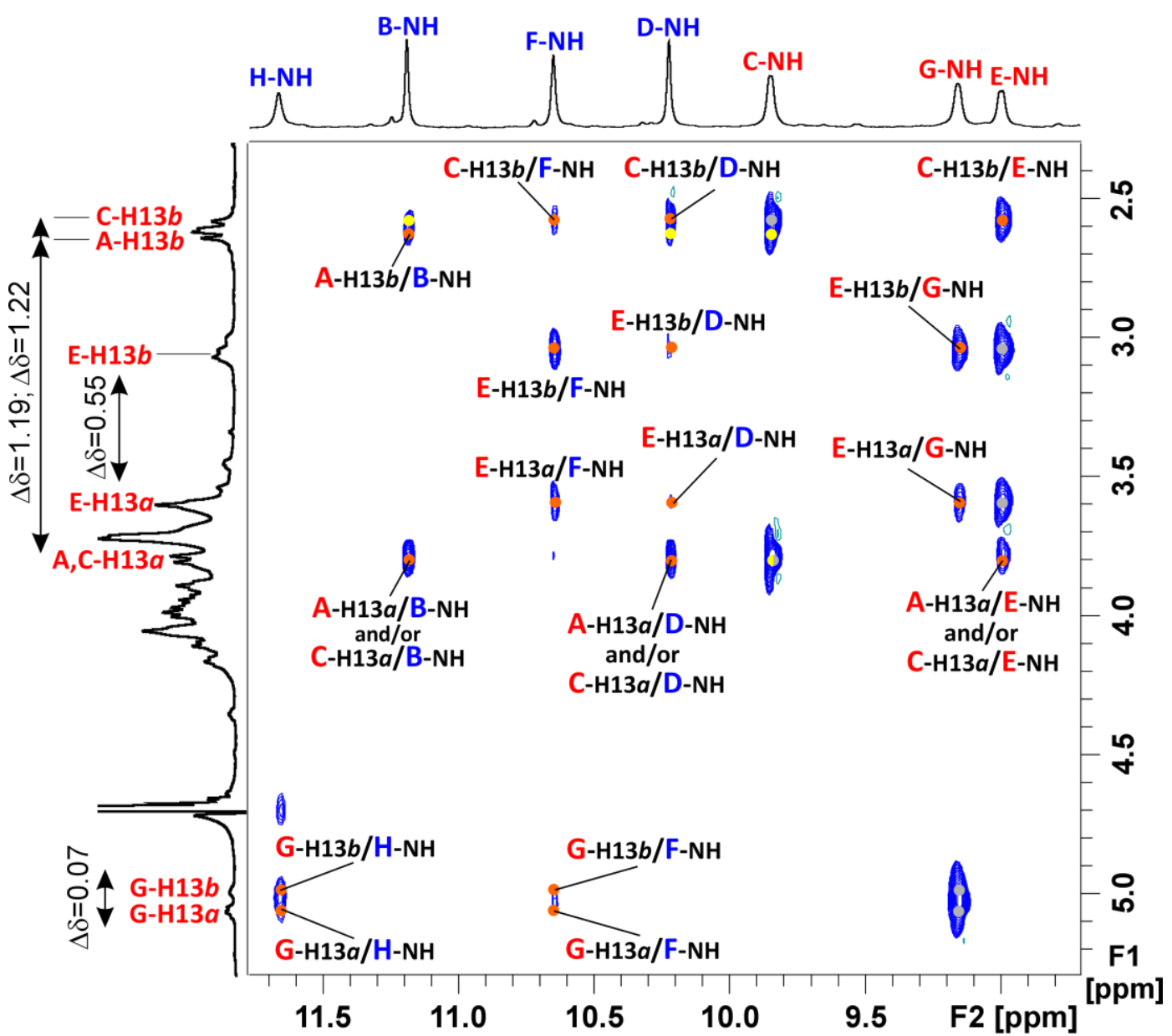

Supplementary Figure 28. Part of the ${ }^{1} \mathrm{H}-{ }^{1} \mathrm{H} 700 \mathrm{MHz}$ NOESY spectrum of $\left({ }^{\mathrm{m}} \mathrm{QQ}^{4}\right)_{4}(2 \mathrm{mM}$ in 50 $\mathrm{mM}$ ammonium bicarbonate in $\left.\mathrm{H}_{2} \mathrm{O} / \mathrm{D}_{2} \mathrm{O}(9: 1 \mathrm{vol} / \mathrm{vol})\right)$ recorded with an $800 \mathrm{~ms}$ mixing time showing dipolar couplings between amide protons and $\mathrm{H} 13$ protons. NOE correlations between ${ }^{\mathrm{m}} \mathrm{Q}$ and $\mathrm{Q}^{4}$ units are marked in orange; correlations between neighbouring protons within the same ${ }^{\mathrm{m}} \mathrm{Q}$ or $\mathrm{Q}^{4}$ unit are marked in grey and are not labelled; expected correlations that cannot be distinguished from overlapping and more intense correlations are marked in yellow and are not labelled. 


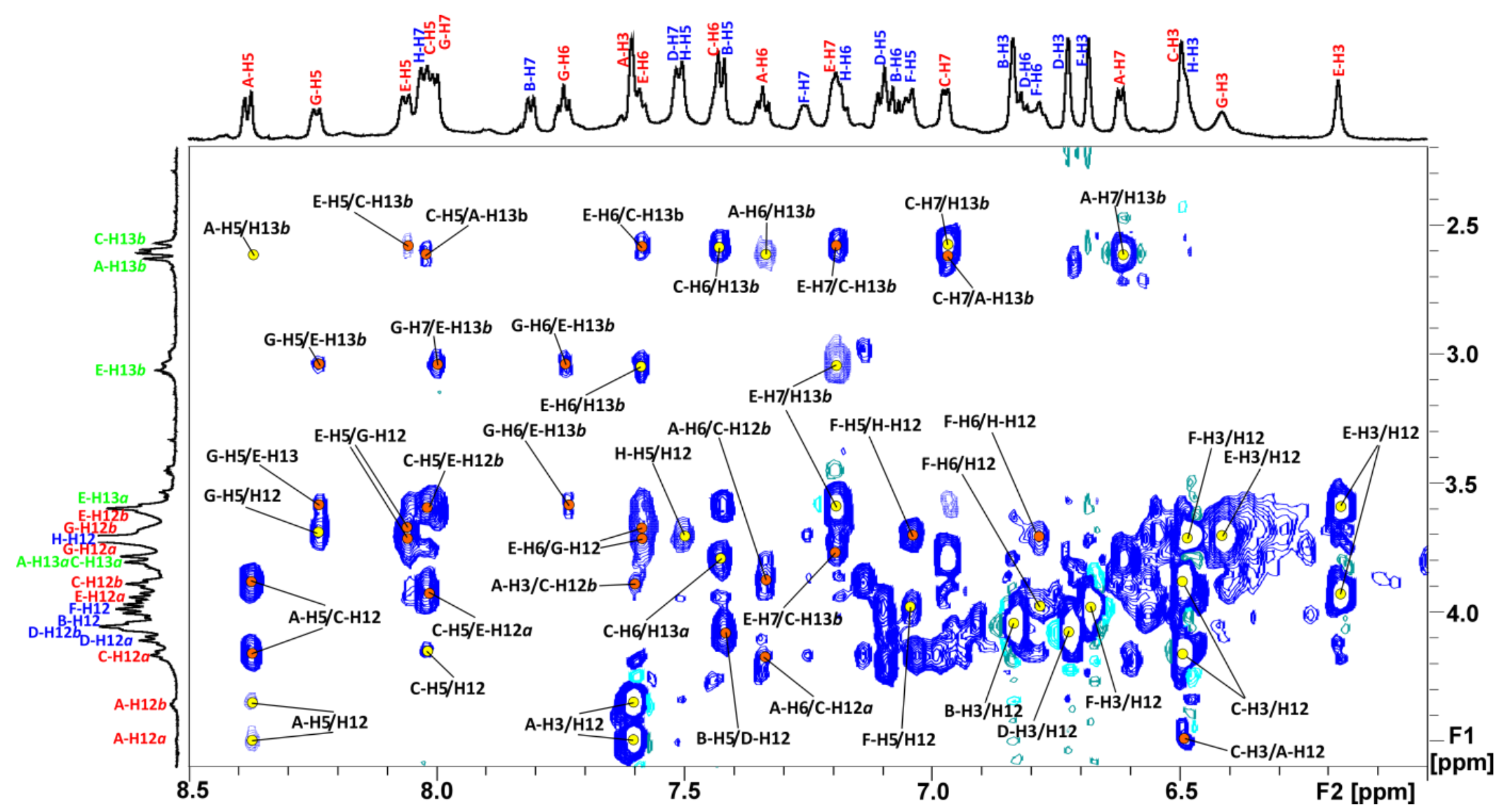

Supplementary Figure 29. Part of the ${ }^{1} \mathrm{H}-{ }^{1} \mathrm{H} 700 \mathrm{MHz}$ NOESY spectrum of $\left({ }^{\mathrm{m}} \mathrm{QQ}^{4}\right)_{4}\left(2 \mathrm{mM}\right.$ in $50 \mathrm{mM}$ ammonium bicarbonate in $\mathrm{H}_{2} \mathrm{O} / \mathrm{D}_{2} \mathrm{O}(9: 1$ $\mathrm{vol} / \mathrm{vol})$ ) recorded with an $800 \mathrm{~ms}$ mixing time showing remarkable cross-peaks between main chain benzylic (H13), side chain (H12) and aromatic protons. NOE correlations within the same ${ }^{\mathrm{m}} \mathrm{Q}$ or $\mathrm{Q}^{4}$ unit are marked in yellow. NOE correlations between ${ }^{\mathrm{m}} \mathrm{Q}$ and $\mathrm{Q}^{4}$ units are marked in orange. On the F1 axis, labels of $\mathrm{H} 12$ signals of ${ }^{\mathrm{m}} \mathrm{Q}$ and $\mathrm{Q}^{4}$ units are coloured red and blue, respectively; labels of $\mathrm{H} 13$ are coloured green. Consistent with the crystal structures, Side chains H12 protons show strong correlations with the neighbour H3 proton and weak correlations with the H5 proton of the same ring, indicating a prevalent orientation of the side chain. We note that side chain $\mathrm{H} 12$ protons show strong anisochronicity in ${ }^{\mathrm{m}} \mathrm{Q}$ units $(\Delta \delta$ $=0.14-0.33 \mathrm{ppm}$ for $\mathrm{A}, \mathrm{C}, \mathrm{E})$ while anisochronicity is weak in $\mathrm{Q}^{4}$ units $(\Delta \delta=0-0.04 \mathrm{ppm})$. 


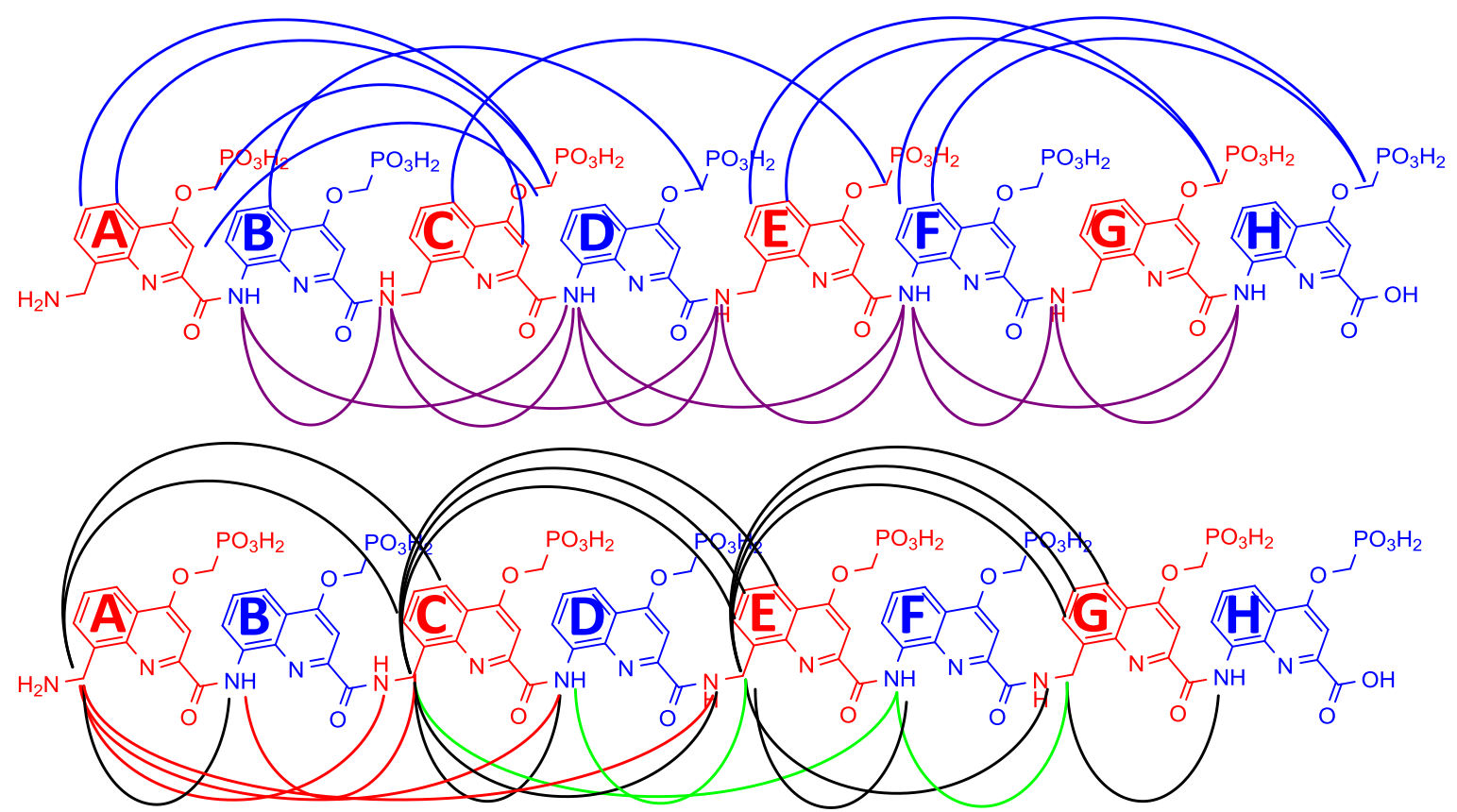

Supplementary Figure 30. Graphical representations of selected ${ }^{1} \mathrm{H}-{ }^{1} \mathrm{H}$ NOESY correlations used for structure elucidation of $\left({ }^{\mathrm{m}} \mathrm{QQ}^{4}\right)_{4}$. Correlations are dispatched over two structures for clarity and colour coded as follows: violet - correlations between NH protons, blue - correlations involving H12 protons, black - correlations involving H13 protons, green - weak correlations, red expected correlations that cannot be distinguished from overlapping correlations.

Supplementary Figure 31. Simplified tube representation of the helical structure of $\left({ }^{\mathrm{m}} \mathrm{QQ}^{4}\right)_{4}$ helix based on $\mathrm{X}$ Ray structures highlighting the different chemical surroundings of diastereotopic benzylic $\mathrm{H} 13$ protons of ${ }^{\mathrm{m}} \mathrm{Q}$ units that result in strong anisochronicity. H13 protons belonging to units $\mathrm{A}, \mathrm{C}$ and $\mathrm{E}$ are shielded by the next ${ }^{\mathrm{m}} \mathrm{Q}$ ring in the sequence, resulting in significant upfield shifts. This effect is more pronounced for $\mathrm{H} 13 \mathrm{~b}$ protons (in yellow) which are pointing directly towards the next ${ }^{\mathrm{m}} \mathrm{Q}$ ring than for the H13a protons (in green). As a results, signals of the former are found in the 2.5-3.0 ppm range whereas signals of the latter are found in the 3.5$3.8 \mathrm{ppm}$ range. Protons $\mathrm{H} 13 \mathrm{a}$ and $\mathrm{H} 13 \mathrm{~b}$ of ${ }^{\mathrm{m}} \mathrm{Q}$ unit $\mathrm{G}$ which is closest to the $\mathrm{C}$ terminus of the sequence, have no ${ }^{\mathrm{m}} \mathrm{Q}$ unit above to shield them. Their signals are found near $5 \mathrm{ppm}$ and show weak anisochronicity.

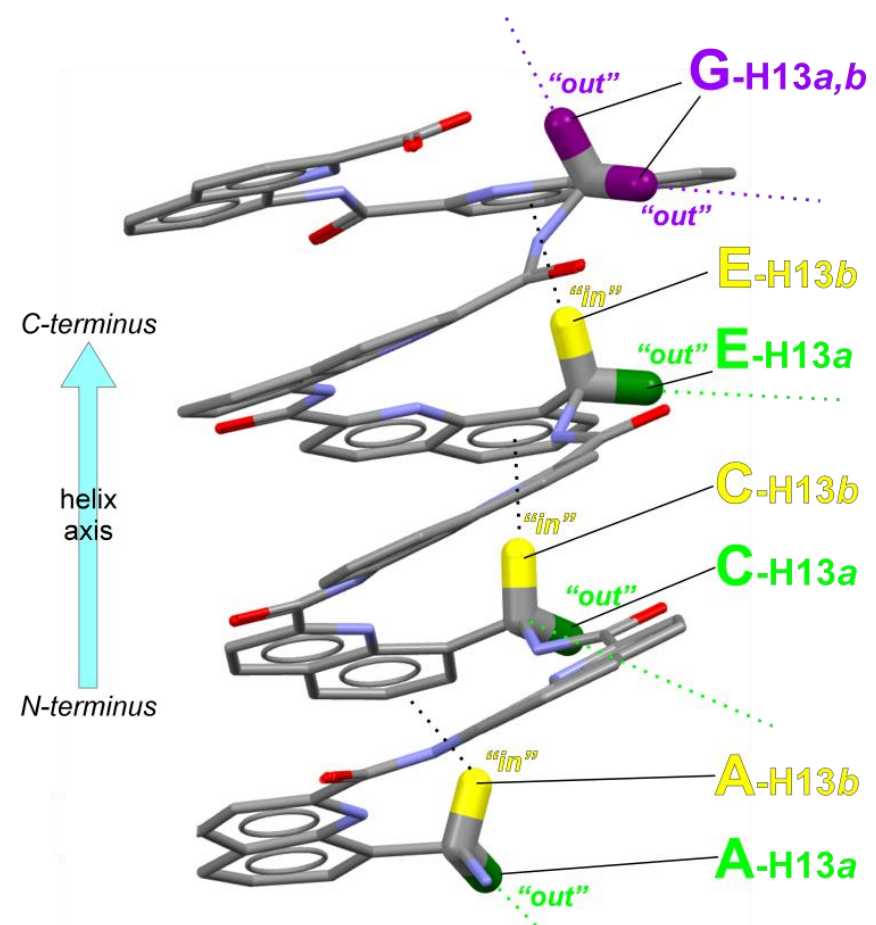




\subsection{Mass Spectrometry analyses}

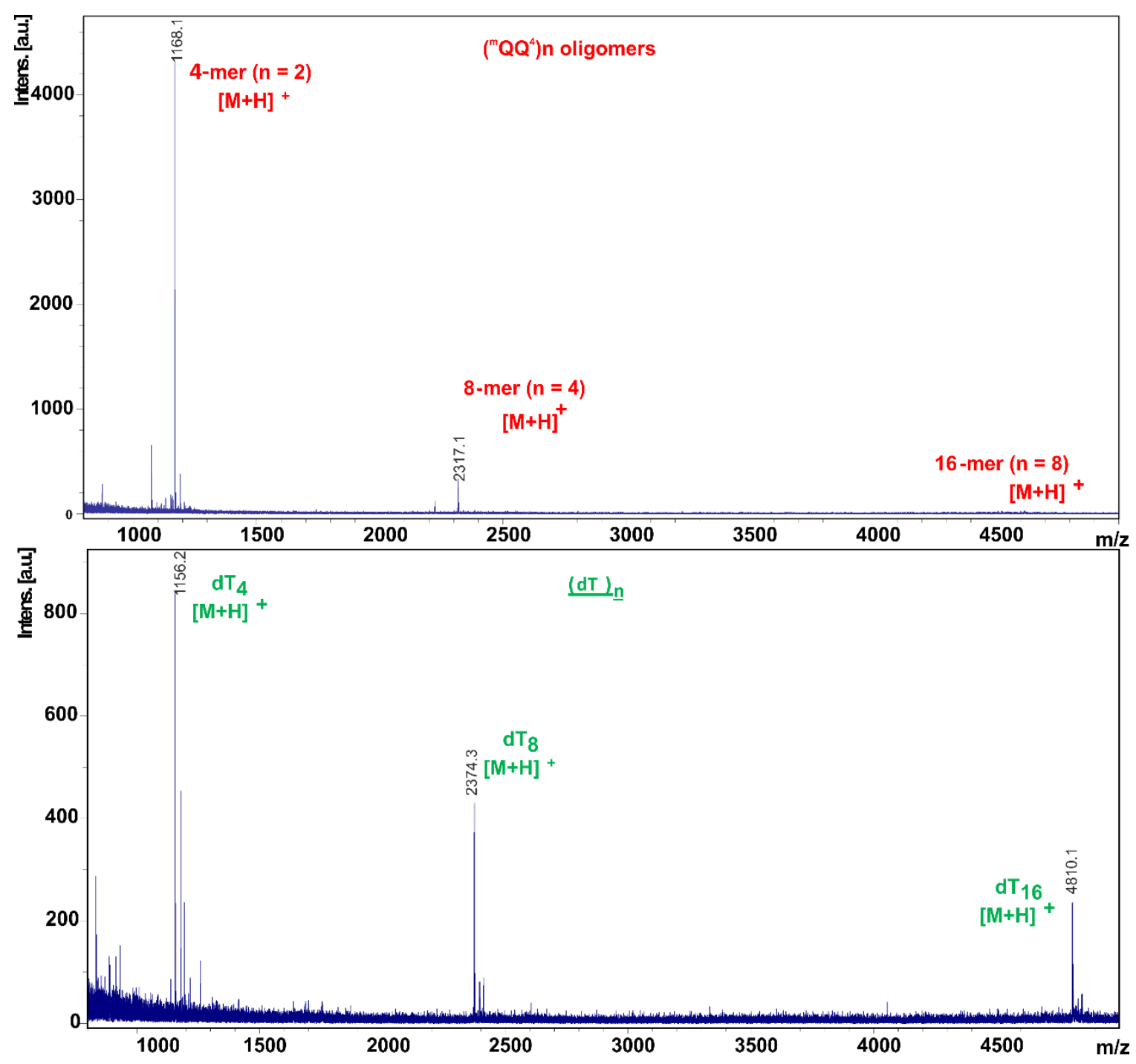

Supplementary Figure 32. Comparison of the mass spectrometric profiles of equimolar mixtures of $\left({ }^{\mathrm{m}} \mathrm{QQ}^{4}\right)_{\mathrm{n}}$ oligomers (top) and of oligo-deoxynucleotides of similar size (bottom) using Matrix Assisted Laser Desorption Ionisation (MS) showing a sharper drop of desorption/ionization as a function of length for $\left({ }^{\mathrm{m}} \mathrm{QQ}^{4}\right)_{\mathrm{n}}$ oligomers than for DNA leading to the unability to detect $\left({ }^{\mathrm{m}} \mathrm{QQ}^{4}\right)_{4}$ whereas this signal is easily detected when this molecule is analysed in the same mode but separately. 

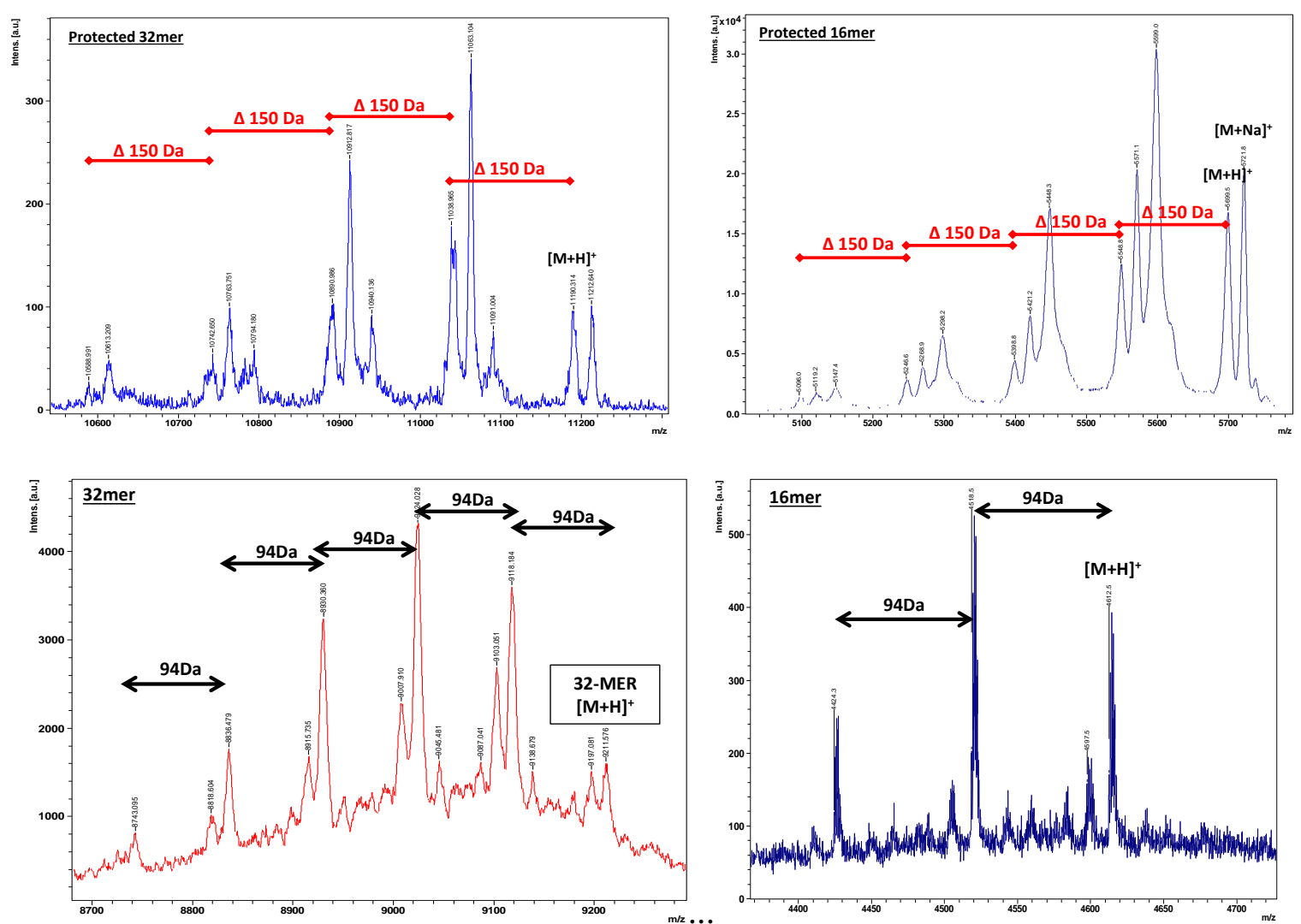

Supplementary Figure 33. Foldamer fragmentation during MALDI-MS analysis. MALDI causes a loss of the side chains of both protected and deprotected long oligomers. MALDI-MS spectra of fully protected $\left({ }^{\mathrm{m}} \mathrm{QQ}^{4}\right)_{8}(\mathbf{S 3 1})$ and $\left({ }^{\mathrm{m}} \mathrm{QQ}^{4}\right)_{16}(\mathbf{S 3 5})$ (top), show peaks at 150 Dalton intervals, whereas MALDI-MS spectra of deprotected $\left({ }^{\mathrm{m}} \mathrm{QQ}^{4}\right)_{8}$ and $\left({ }^{\mathrm{m}} \mathrm{QQ}^{4}\right)_{16}$ (bottom), show peaks at 94 Dalton intervals.

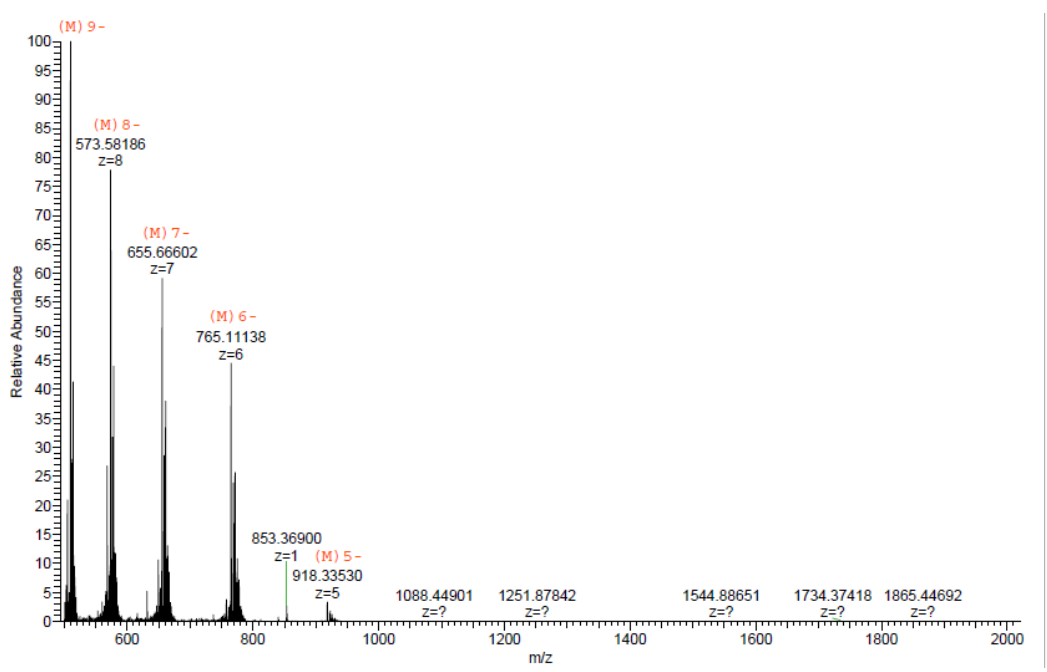

Supplementary Figure 34. Multicharged species observed by ESI-MS (anionic mode) of the deprotected oligomers. The example of $\left({ }^{\mathrm{m}} \mathrm{QQ}^{5}\right)_{8}$ is shown. No fragmentation of the side chains is observed. 
a)

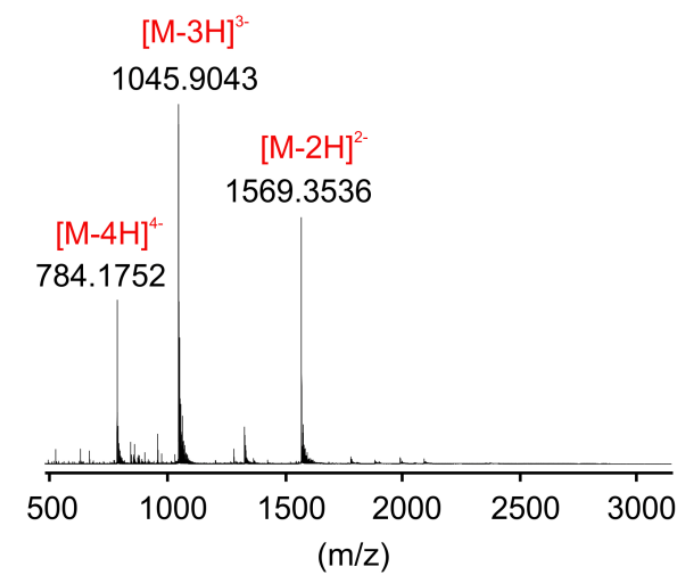

b)

$$
[\mathrm{M}-4 \mathrm{H}]^{4-}
$$

1358.4920

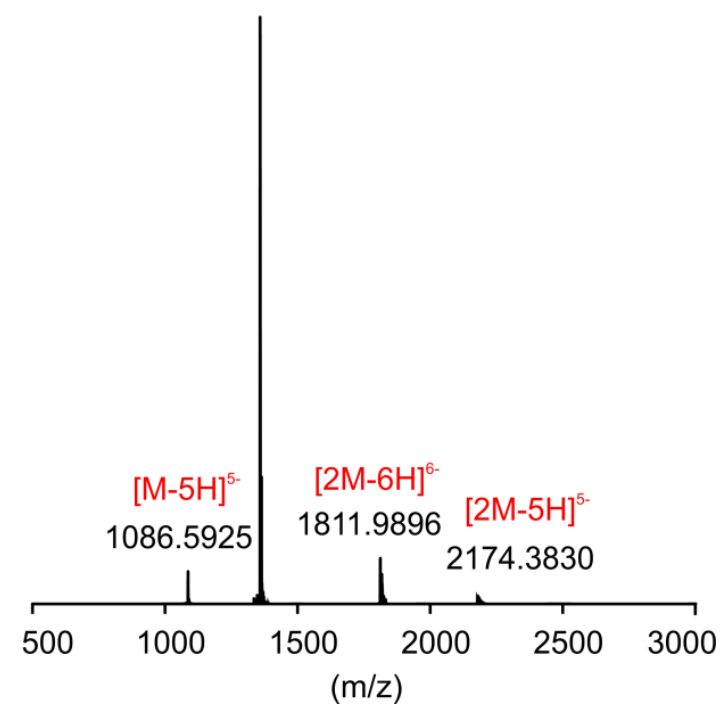

Supplementary Figure 35. Multicharged species observed by HRMS ESI MS (anionic mode) of the biotin-oligomer conjugates, biotin- $\left({ }^{\mathrm{m}} \mathrm{QQ}^{4}\right)_{4}$ (a) and biotin- $\left({ }^{\mathrm{m}} \mathrm{QQ}^{4}\right)_{8}$ (b) after exchange of triethylammonium to ammonium cations.

\section{$2.6 \mathrm{pH}$ titration curves}
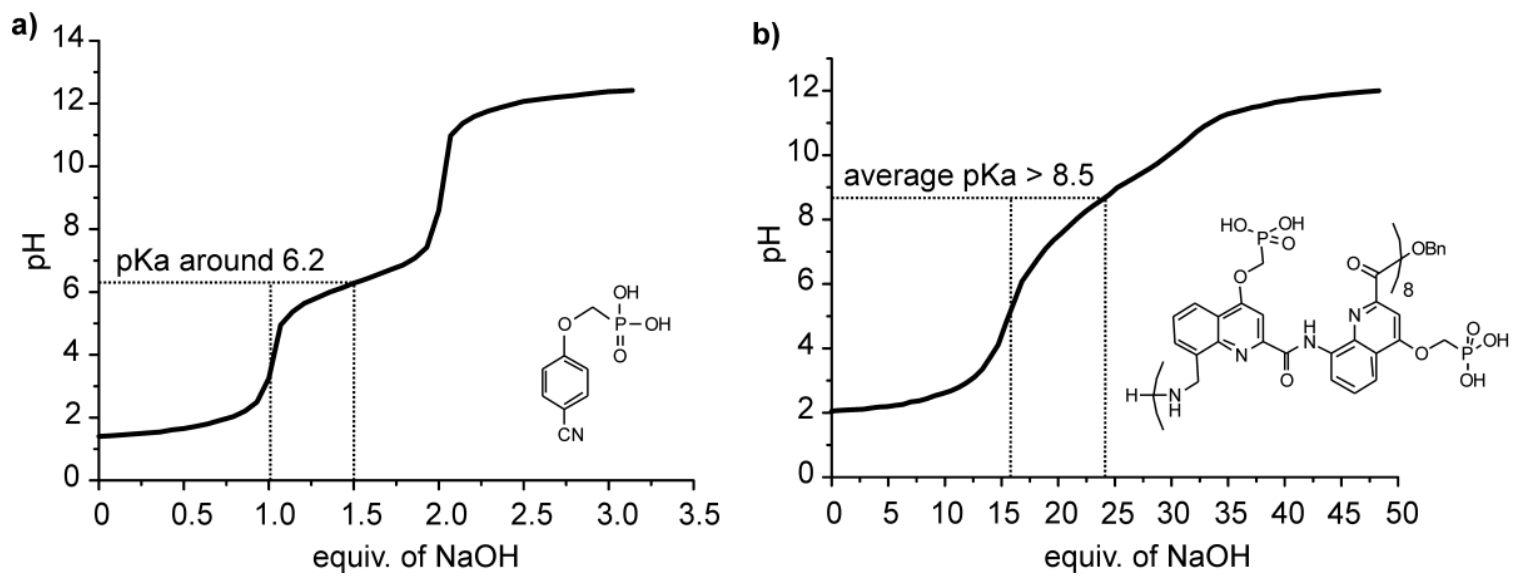

Supplementary Figure 36. pH titration curves of model phosphonate monomer S53 (a) and phosphonate oligomer $\left({ }^{\mathrm{m}} \mathrm{QQ}_{4}\right)_{8}(\mathrm{~b})$, showing a strong increase of the average value of the second $\mathrm{pKa}$ for the latter. 


\subsection{Biological investigations}

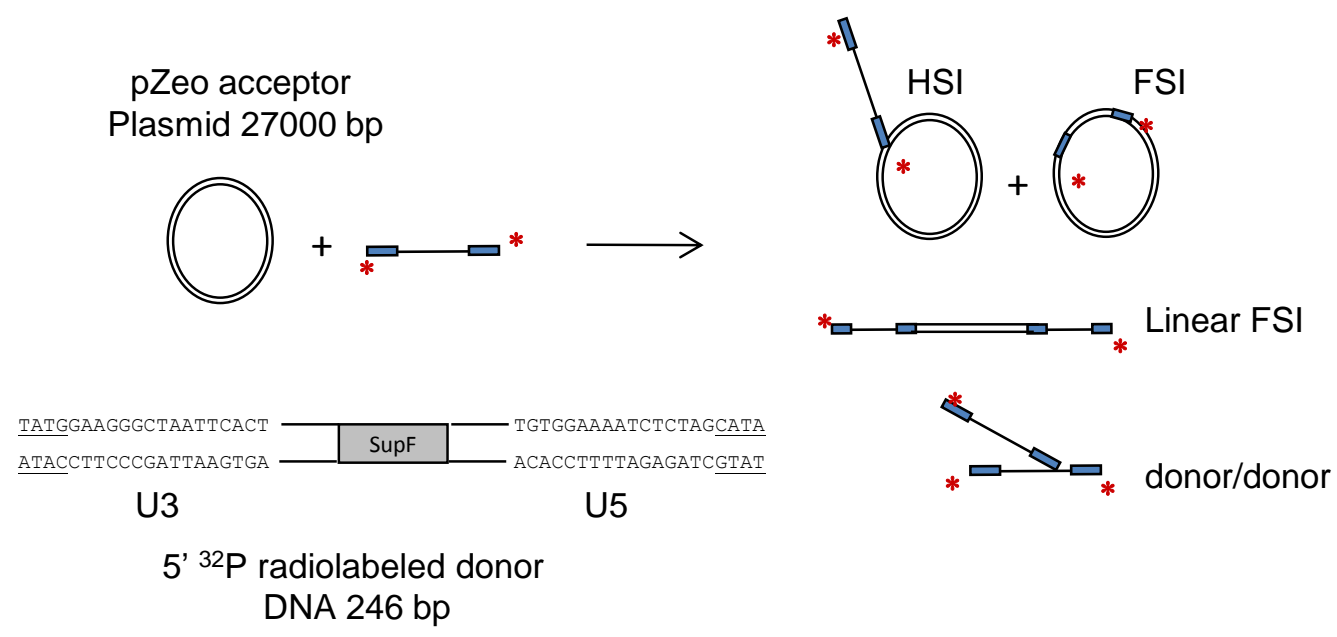

Supplementary Figure 37. Principle of in vitro HIV-1 concerted integration activity assay. A radiolabeled 246 bp DNA donor is mixed with a 2,700 bp plasmid acceptor. Different products are obtained including half-site (HSI), circular and linear full-site (FSI) and donor/donor (d/d) integration.

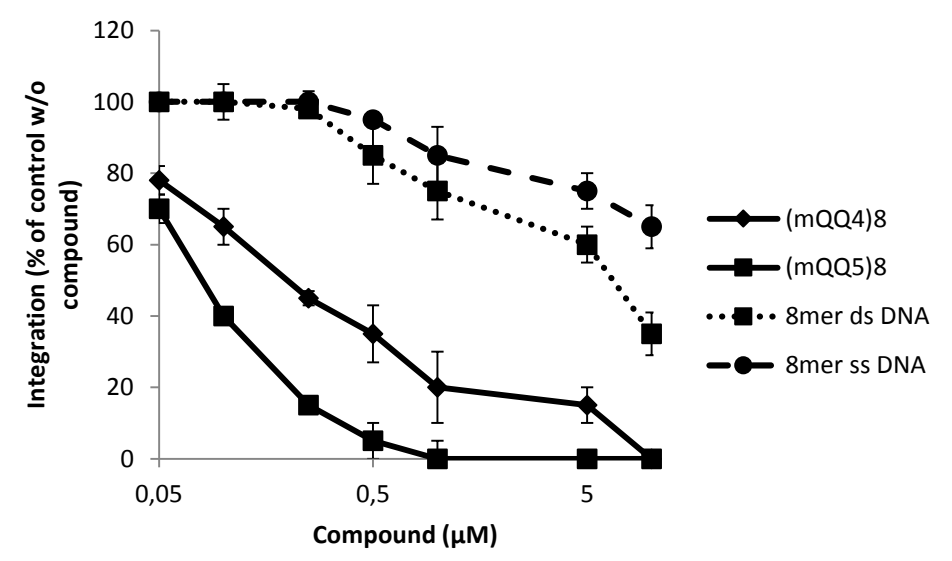

Supplementary Figure 38. Effect of $\left({ }^{\mathrm{m}} \mathrm{QQ}^{4}\right)_{8},\left({ }^{\mathrm{m}} \mathrm{QQ}{ }^{5}\right)_{8}$ and 8mer single stranded and double stranded DNA on in vitro HIV-1 concerted integration activity. Increasing concentrations of compounds were added to a typical concerted integration assay. The reaction products were loaded onto $1 \%$ agarose gel and the circular FSI + HSI and linear FSI products were quantified on gel using the ImageJ software. All the values are shown as the mean \pm standard deviation (error bars) of at least three independent sets of experiments. 


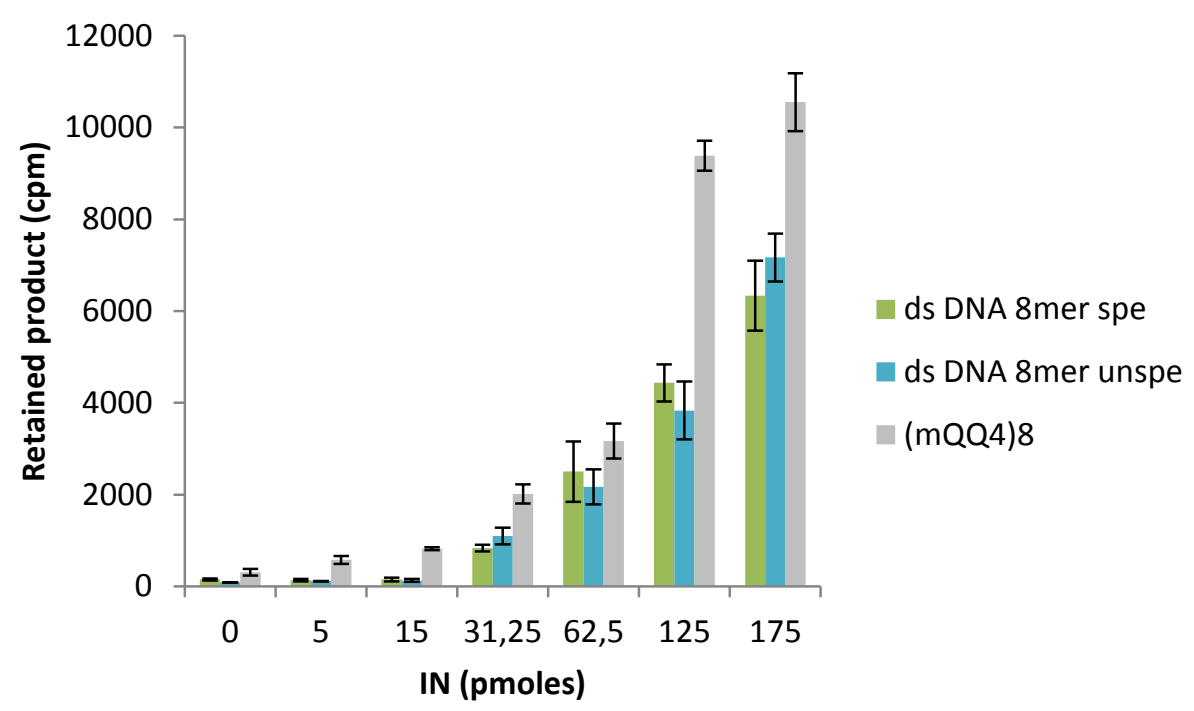

Supplementary Figure 39. Interaction between HIV-IN and $\mathbf{T}^{\mathrm{P32}}-\left({ }^{\mathrm{m}} \mathbf{Q Q}^{4}\right)_{8}$. Complexes formed between IN and $\mathrm{T}^{\mathrm{P} 32}-\left({ }^{\mathrm{m}} \mathrm{QQ}^{4}\right)_{8}$ were loaded on nitrocellulose filter. The retained product was determined by quantifying the radioactivity remaining on the membrane after filtration. Results are the mean \pm standard deviation (error bars) of at least three independent sets of experiments.
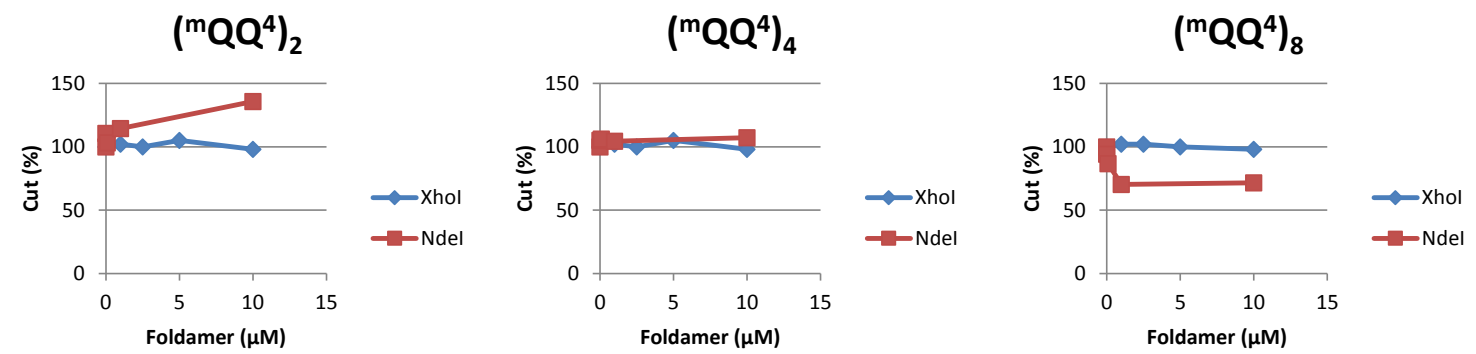

Supplementary Figure 40. Effect of foldamers on NdeI and XhoI in vitro restriction activity. pUC19_SupF_NdeI plasmid DNA was incubated with 1 unit of NdeI or XhoI restriction enzyme and increasing amounts of foldamers and incubated for 1 hour at $37^{\circ} \mathrm{C}$. Reaction products were loaded on $1 \%$ agarose gel. The gel was stained using SybrSafe dye and the products were quantified using ImageJ software. Representative experiments are reported here. 
A-

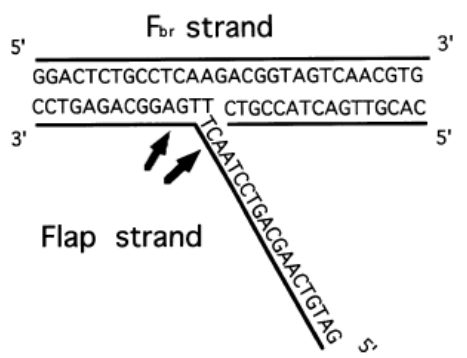

B-
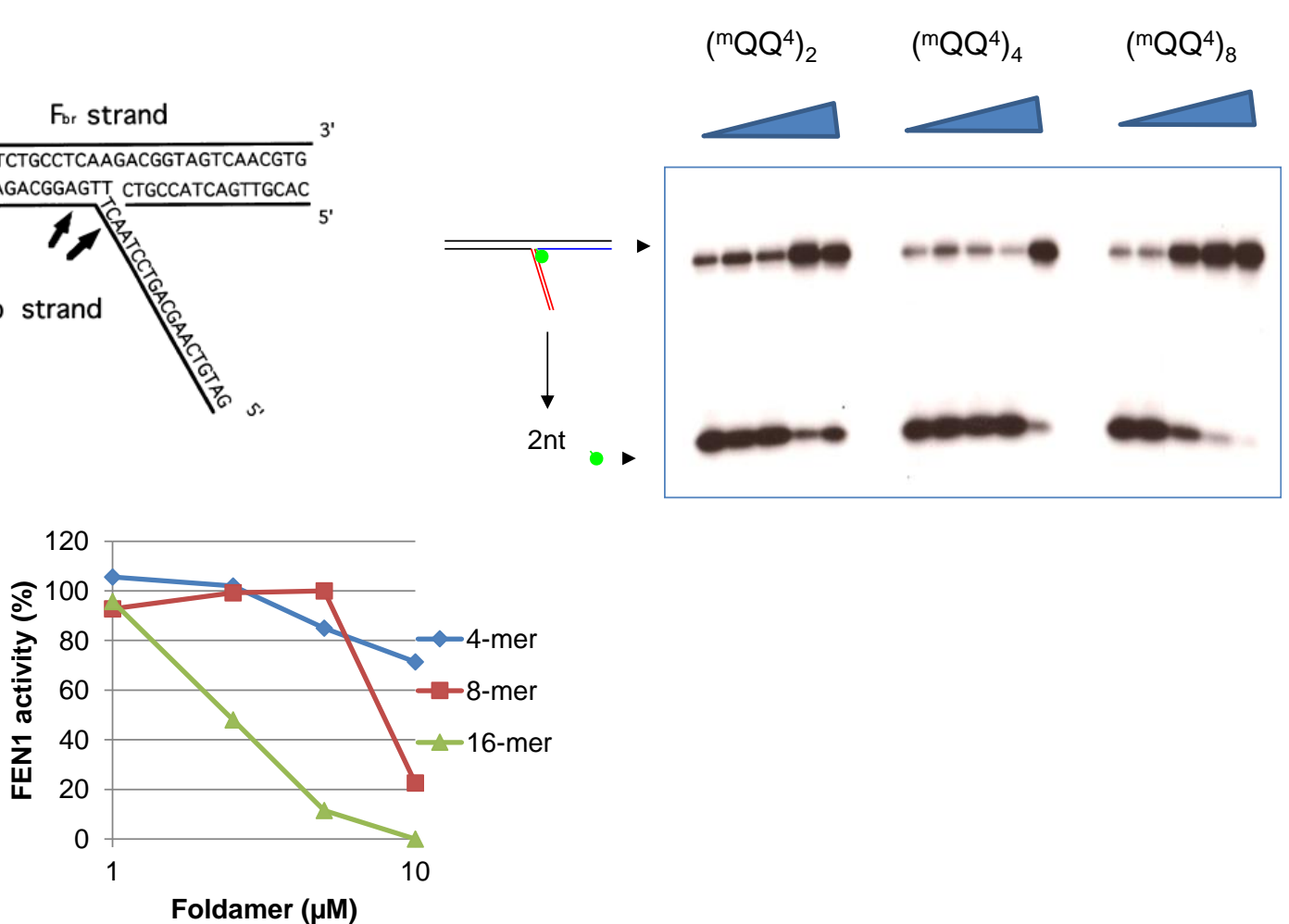

Supplementary Figure 41. Effects of foldamers on human FEN1 in vitro flap cleavage activity. Fen1 substrate was incubated with 1 unit of human FEN1 and increasing concentrations of foldamers and incubated for 1 hour at $37^{\circ} \mathrm{C}$. Reaction products were loaded on $12 \%$ polyacryamide denaturing gel (a). The gel was autoradiographed and the products were quantified using ImageJ software (b). A representative experiment is reported here.
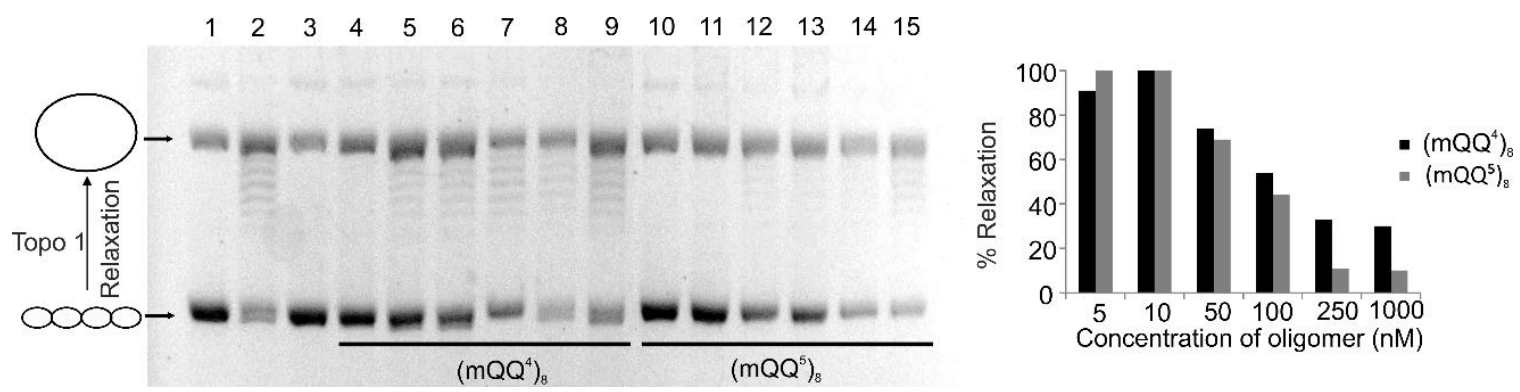

Supplementary Figure 42. Inhibition of Top1-mediated relaxation of supercoiled pcDNA3.1 by $\left({ }^{\mathrm{m}} \mathrm{QQ}^{4}\right)_{8}$ and $\left({ }^{\mathrm{m}} \mathrm{QQ}^{5}\right)_{8}$. Top1 inhibition was expressed as a percentage of relaxation compared with that of control (enzyme alone). Results are the means of triplicate experiments \pm standard deviation. The bar graphs shown on the left corresponds to the quantitation of the gels. Lane 1, control pcDNA; lane 2 control pcDNA + Top1; lane 3, pcDNA + Top1 + Camptothecin (CPT) $50 \mu \mathrm{M}$; lanes 4 to 9 , same as lane $2+1 \mu \mathrm{M}, 250 \mathrm{nM}, 100 \mathrm{nM}, 50 \mathrm{nM}, 10 \mathrm{nM}$ or $5 \mathrm{nM}$ of $\left({ }^{\mathrm{m}} \mathrm{QQ}^{4}\right)_{8}$; lanes 10 to 15 , same as lane $2+1 \mu \mathrm{M}, 250 \mathrm{nM}, 100 \mathrm{nM}, 50 \mathrm{nM}, 10 \mathrm{nM}$ or $5 \mathrm{nM}$ of $\left({ }^{\mathrm{m}} \mathrm{QQ}^{5}\right)_{8}$. 


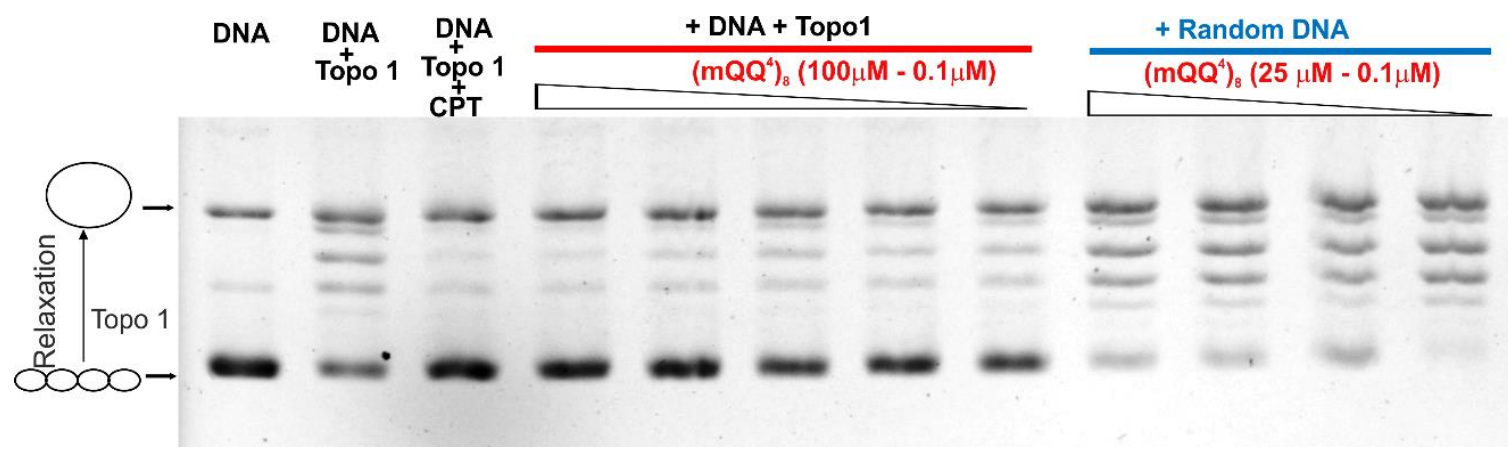

Supplementary Figure 43. Inhibition of Top1-mediated relaxation of supercoiled pcDNA3.1 by $\left({ }^{\mathrm{m}} \mathrm{QQ}^{4}\right)_{8}$ and a random eight base-pair DNA double stranded sequence. The random DNA shows no inhibitory effect. On the contrary, Top-1 activity appears to be slightly enhanced.

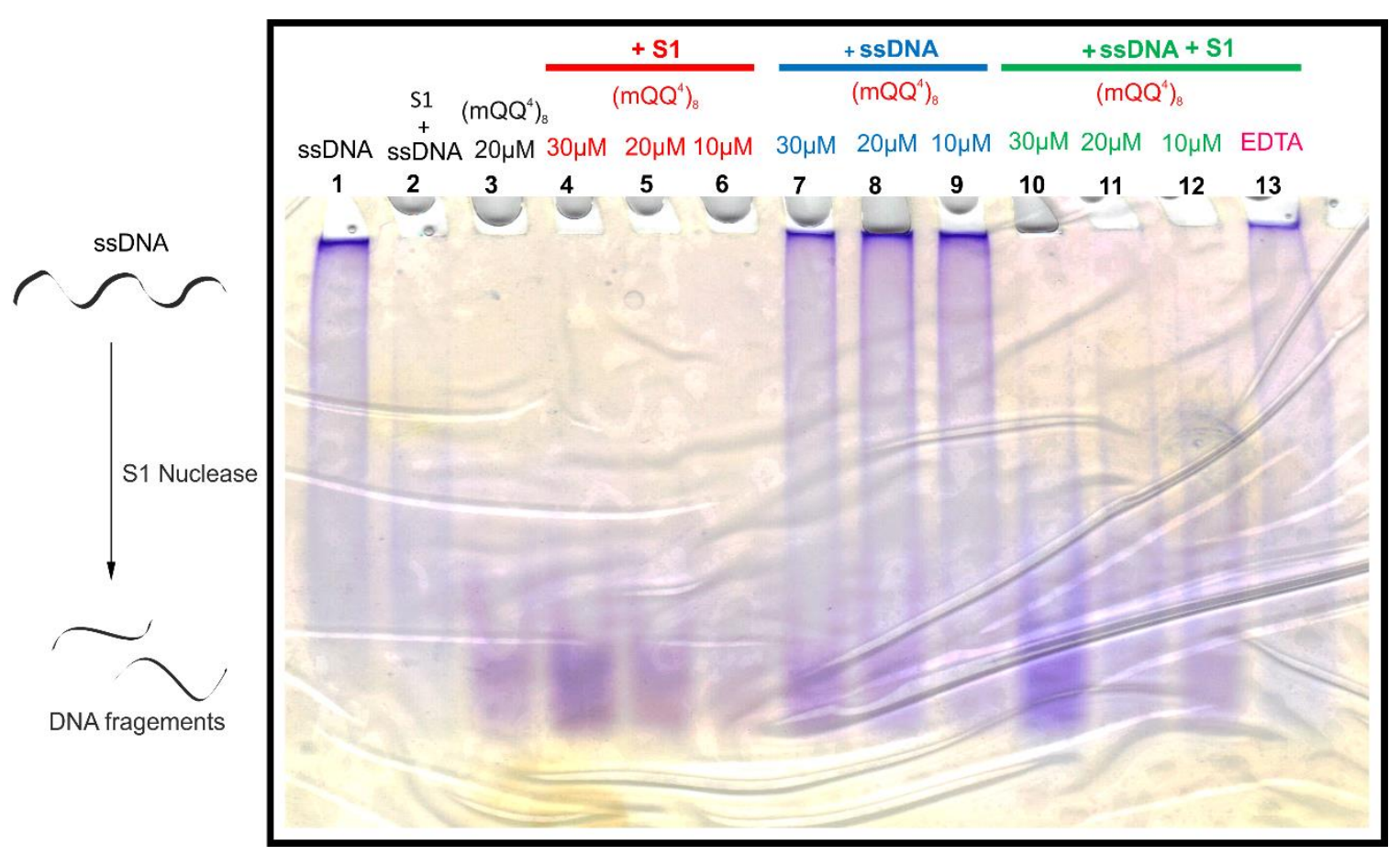

Supplementary Figure 44. Effect of $\left({ }^{\mathrm{m}} \mathrm{QQ}^{4}\right)_{8}$ on $\mathrm{S}_{1}$ Nuclease activity. The Nuclease $\mathrm{S} 1$ enzyme from Aspergillus oryzae has the ability to degrade single-stranded (ss) oligonucleotides composed of either deoxynucleotides or ribonucleotides (DNA or RNA). Reactions used $5 \mu \mathrm{g}$ of single strand salmon sperm DNA, 2 units of $S_{1}$ Nuclease in the absence or presence of $30 \mu \mathrm{M}, 20 \mu \mathrm{M}$ and 10 $\mu \mathrm{M}$ of $\left({ }^{\mathrm{m}} \mathrm{QQ}^{4}\right)_{8}$. Lane 1, control ssDNA; lane 2, control ssDNA $+\mathrm{S}_{1}$; lane 3, control $\left({ }^{\mathrm{m}} \mathrm{QQ}^{4}\right)_{8} 20 \mu \mathrm{M}$; lanes 4 to $6, \mathrm{~S}_{1}+30 \mu \mathrm{M}, 20 \mu \mathrm{M}$ or $10 \mu \mathrm{M}$ of $\left({ }^{\mathrm{m}} \mathrm{QQ}^{4}\right)_{8}$; lanes 7 to 9 , ssDNA $+30 \mu \mathrm{M}, 20 \mu \mathrm{M}$ or 10 $\mu \mathrm{M}$ of $\left({ }^{\mathrm{m}} \mathrm{QQ}^{4}\right)_{8}$; lanes 10 to 13 , ssDNA $+\mathrm{S}_{1}+30 \mu \mathrm{M}, 20 \mu \mathrm{M}$ or $10 \mu \mathrm{M}$ of $\left(\mathrm{mQQ}^{4}\right)_{8}$; lane $13, \mathrm{~S}_{1}$ inhibition by adding $0.5 \mathrm{M}$ EDTA. 


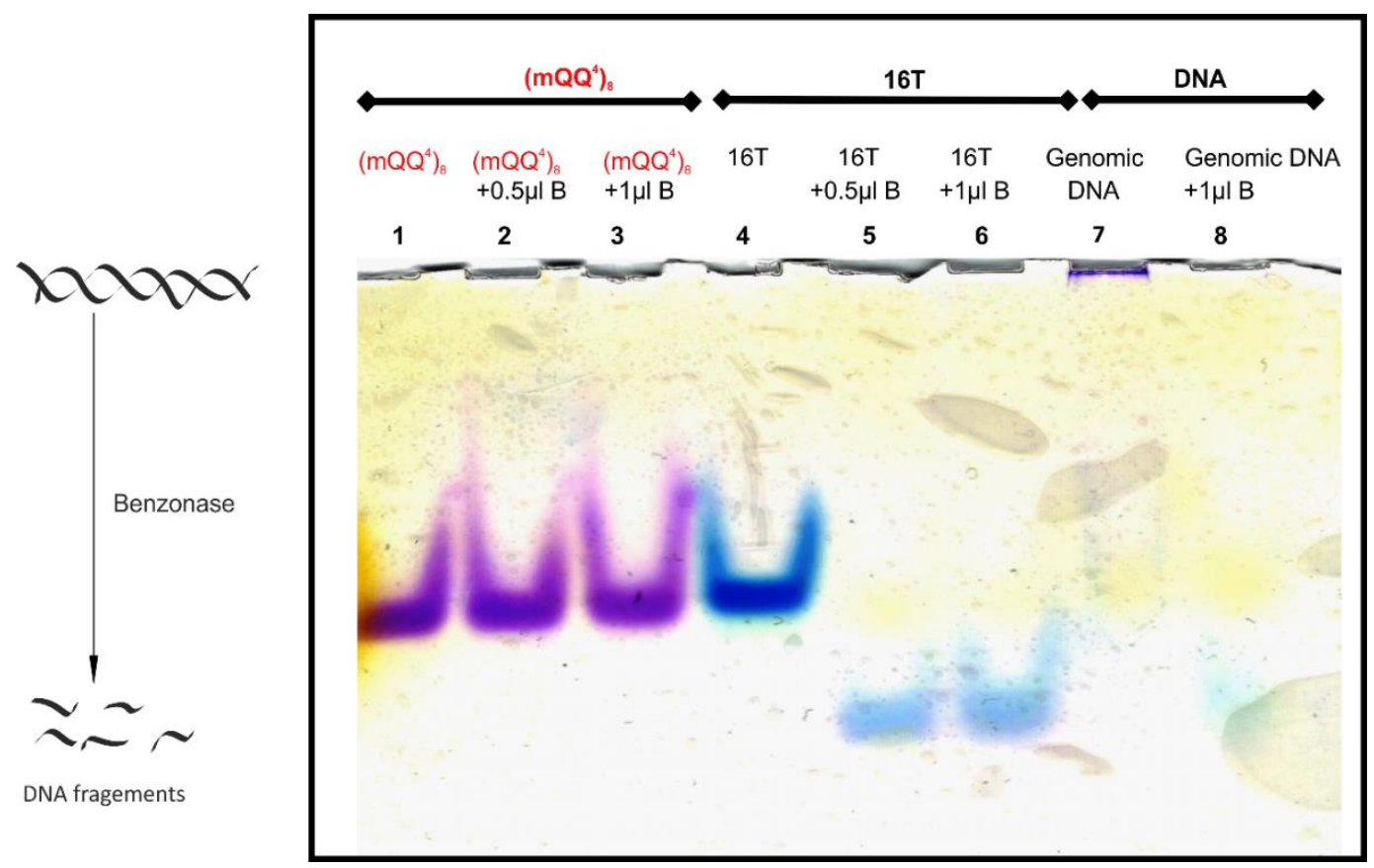

Supplementary Figure 45. Comparison of degradation of $(\mathrm{dT})_{16}$ and $\left({ }^{\mathrm{m}} \mathrm{QQ}^{4}\right)_{8}$ by Benzonase ${ }^{\circledR}$. This enzyme attacks and degrades all forms of DNA and RNA (single stranded, double stranded, linear and circular). Reactions used 0.5 or $1 \mu \mathrm{L}$ of Benzonase in the presence of $1 \mu \mathrm{g}$ of $\left({ }^{\mathrm{m}} \mathrm{QQ}^{4}\right)^{8}$, $1 \mu \mathrm{g}$ of $(\mathrm{dT})_{16}$ or $1 \mu \mathrm{g}$ of genomic DNA. Lanes 1 to $3,1 \mu \mathrm{g}$ of $\left({ }^{\mathrm{m}} \mathrm{QQ}^{4}\right)_{8}+0,0.5$ or $1 \mu \mathrm{L}$ of Benzonase; lanes 4 to $6,(\mathrm{dT})_{16}+0,0.5$ or $1 \mu \mathrm{L}$ of Benzonase; lanes 7 and 8 , genomic DNA +0 and $1 \mu \mathrm{L}$ of Benzonase.

(A)
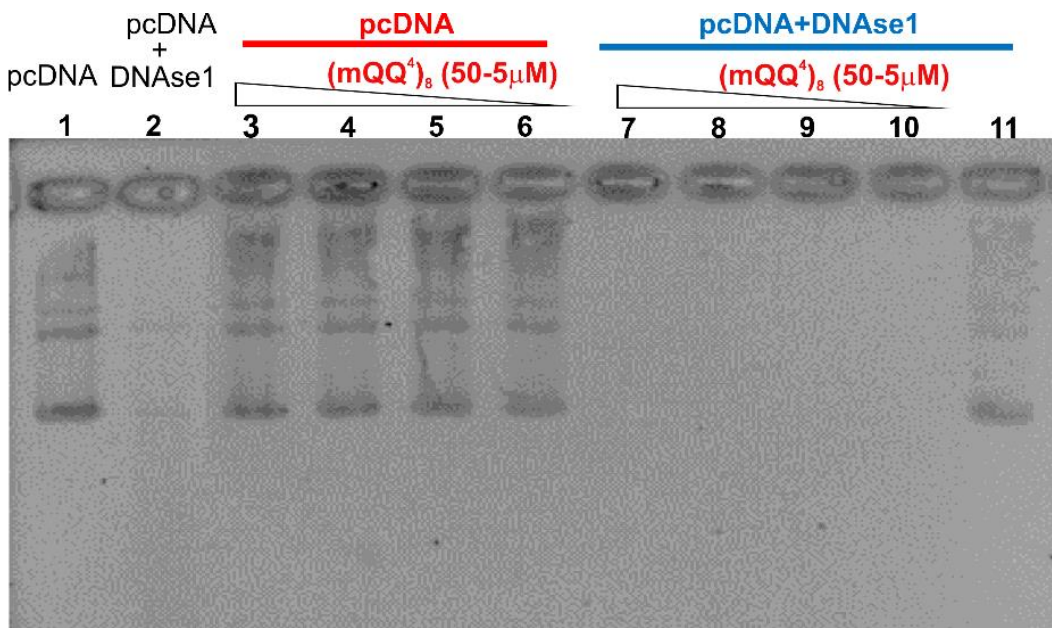

(B)

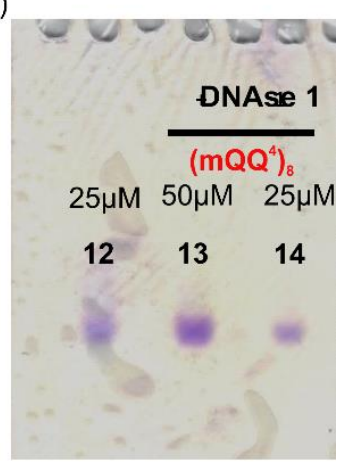

Supplementary Figure 46. Impact of $\left({ }^{\mathrm{m}} \mathrm{QQ}^{4}\right)_{8}$ on DNase I activity (DNase I is a versatile enzyme that nonspecifically cleaves DNA to release 5'-phosphorylated di-, tri-, and oligonucleotide products). Reactions used $100 \mathrm{ng}$ of double strand plasmid pcDNA3.1, 1 unit of DNase I in the absence or presence of $50 \mu \mathrm{M}, 25 \mu \mathrm{M}, 10 \mu \mathrm{M}$ and $5 \mu \mathrm{M}$ of $\left({ }^{\mathrm{m}} \mathrm{QQ}^{4}\right)_{8}$. Lane 1, control dsDNA; lane 2 , control dsDNA $+\mathrm{S}_{1}$; lanes 3 to 6 , pcDNA $+50 \mu \mathrm{M}, 25 \mu \mathrm{M}, 10 \mu \mathrm{M}$ and $5 \mu \mathrm{M}$ of $\left({ }^{\mathrm{m}} \mathrm{QQ}^{4}\right)_{8}$; lanes 7 to 10 , pcDNA + DNase I + 50 $\mu \mathrm{M}, 25 \mu \mathrm{M}, 10 \mu \mathrm{M}$ and $5 \mu \mathrm{M}$ of $16 \mathrm{mer}$; lane 11 , DNase I inhibition by adding $0.5 \mathrm{M}$ EDTA; lane 12, control $16 \operatorname{mer}(25 \mu \mathrm{M})$; lanes 13 and 14 , DNase I $+50 \mu \mathrm{M}$ and $25 \mu \mathrm{M}$ of $\left({ }^{\mathrm{m}} \mathrm{QQ}^{4}\right)_{8}$. 

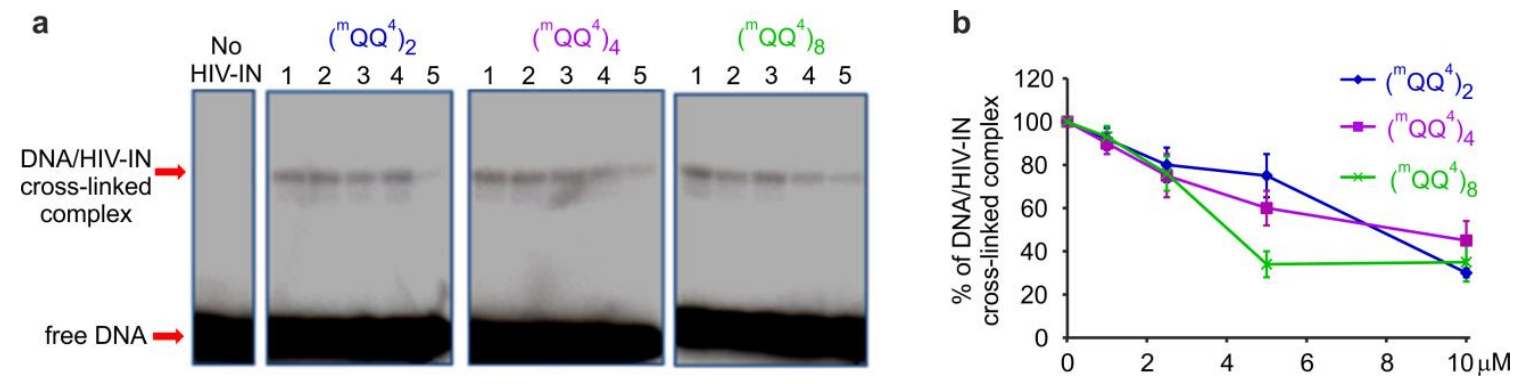

Supplementary Figure 47. a, 12\% polyacrylamide gel electrophoresis of DNA/HIV-IN complex captured by photo-induced cross-linking in presence of increasing amounts of ( $\left.{ }^{\mathbf{m}} \mathbf{Q} \mathbf{Q}_{4}\right)_{\mathrm{n}}$ foldamers. b, Quantitative assessment of the experiment shown in $\mathbf{a}$. Results are the means of duplicate or triplicate experiments \pm standard deviation
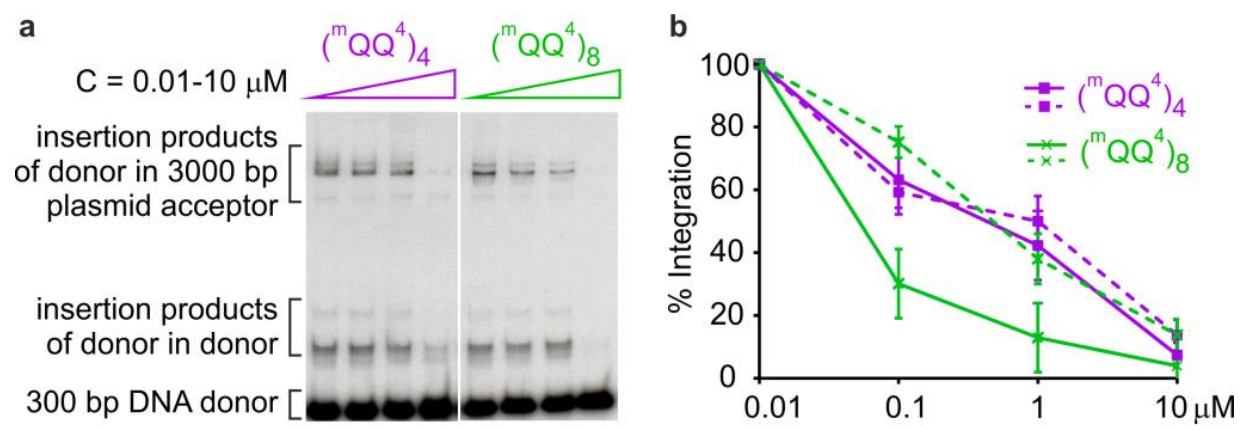

Supplementary Figure 48. a, Inhibition of in vitro HIV-IN integration ( $200 \mathrm{nM}$ of IN) of a radio labelled $246 \mathrm{bp}$ viral DNA donor into a $2700 \mathrm{bp}$ pBSK-Zeo plasmid acceptor by $\left({ }^{\mathrm{m}} \mathrm{QQ}^{4}\right)_{4}$ and $\left({ }^{\mathrm{m}} \mathrm{QQ}^{4}\right)_{8}$ oligomers assessed by $1 \%$ agarose gel electrophoresis. b, Quantitation of the inhibition of wild type HIV-IN (solid lines) and K236A DNA binding-deficient HIV-IN (dashed lines) by $\left({ }^{\mathrm{m}} \mathrm{QQ}^{4}\right)_{4}$ and $\left({ }^{\mathrm{m}} \mathrm{QQ}^{4}\right)_{8}$ oligomers expressed as a percentage of integration related to a control in the absence of inhibitors. Results are the means of duplicate or triplicate experiments \pm standard deviation.

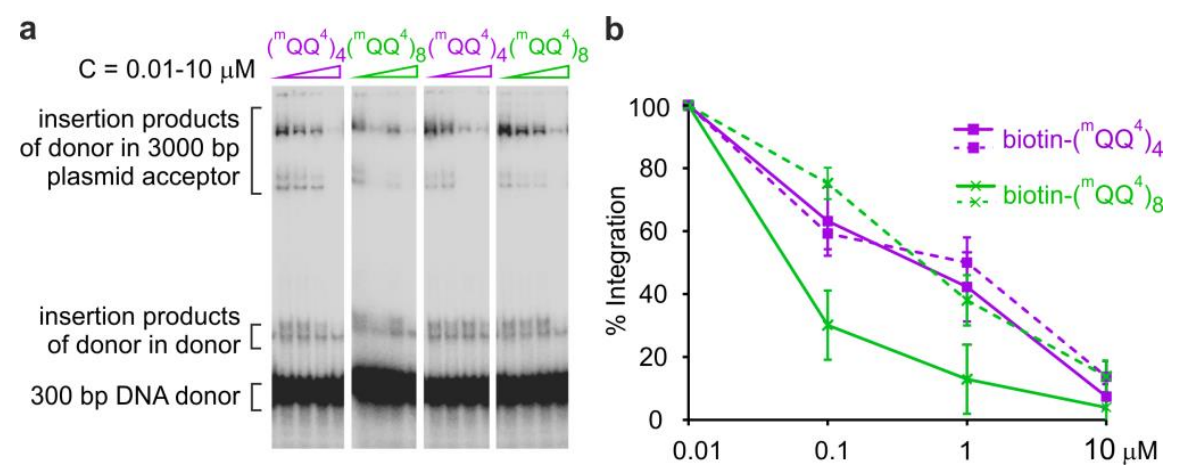

Supplementary Figure 49. a, Inhibition of in vitro HIV-IN integration (200 nM of IN) of a radio labelled 246 bp viral DNA donor into a 2700 bp pZeo plasmid acceptor by biotin- $\left({ }^{\mathrm{m}} \mathrm{QQ}^{4}\right)_{4}$ and biotin- $\left({ }^{\mathrm{m}} \mathrm{QQ}^{4}\right)_{8}$ oligomers assessed by $1 \%$ agarose gel electrophoresis. b, Quantitation of the inhibition of wild type HIV-IN (solid lines) and K236A DNA binding-deficient HIV-IN (dashed lines) by biotin- $\left({ }^{\mathrm{m}} \mathrm{QQ}^{4}\right)_{4}$ and biotin- $\left({ }^{\mathrm{m}} \mathrm{QQ}^{4}\right)_{8}$ oligomers expressed as a percentage of integration related to a control in the absence of inhibitors. Results are the means of duplicate or triplicate experiments \pm standard deviation. 


\section{Pull down experiments}

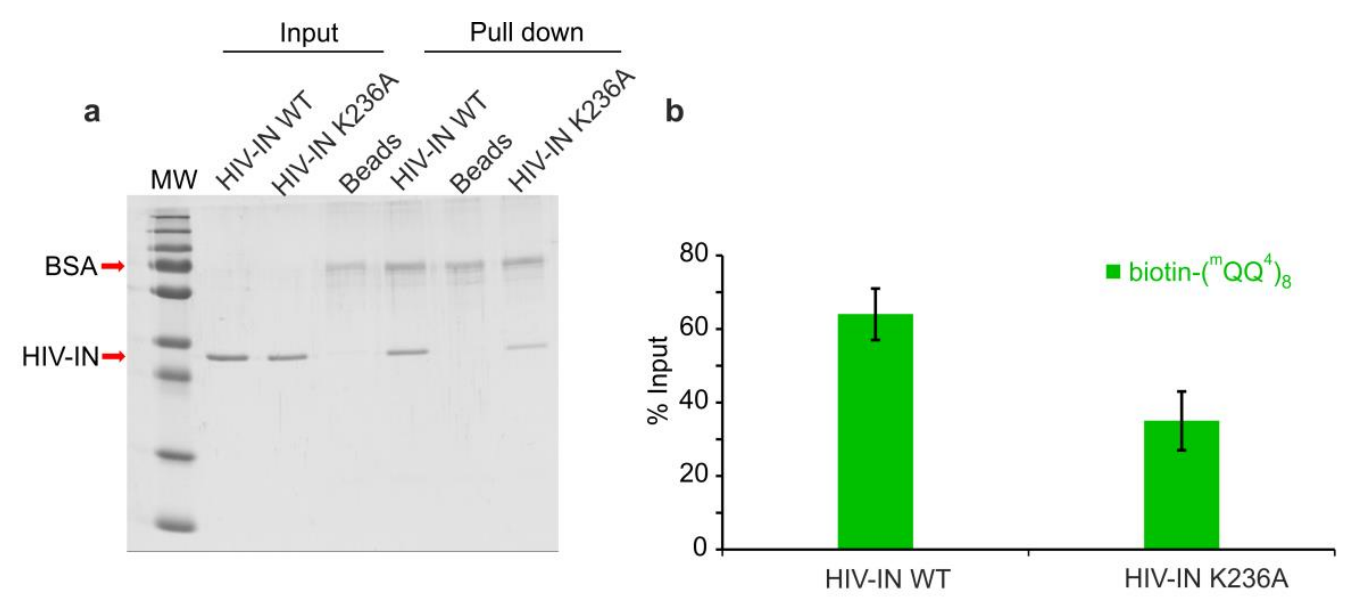

Supplementary Figure 50. a, 12\% SDS-PAGE of HIV-IN and its mutant K236A showing reference protein bands (input) and bands of protein pulled-down by biotin- $\left({ }^{\mathbf{m}} \mathbf{Q} \mathbf{Q}_{4}\right)_{8}$ coupled to streptavidin beads. Non specific binding of the protein on beads is also reported. $\mathbf{b}$, Quantitation of the experiment shown in a reported as percentage of input retained on beads coupled to the foldamer. Results are the means of triplicate experiments \pm standard deviation.

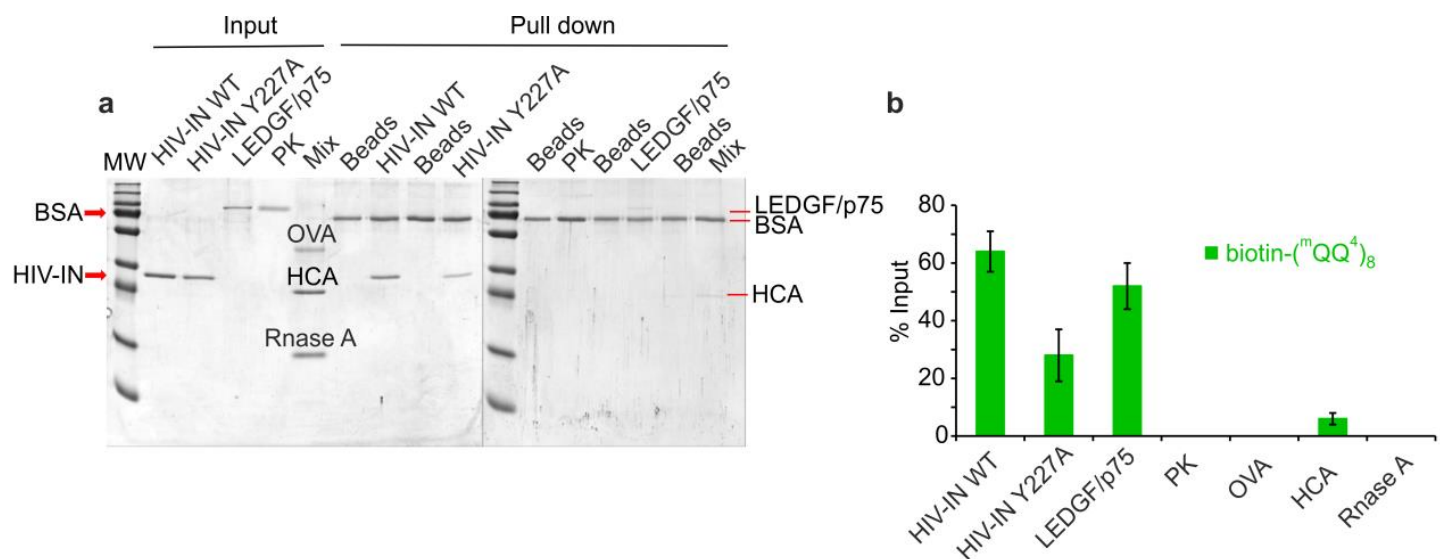

Supplementary Figure 51. a, 12\% SDS-PAGE of purified recombinant proteins including DNA binding proteins (HIV-IN, its mutant Y227A and LEDGF/p75), an RNA binding protein (Ribonuclease A, RnaseA), a protein binding protein (proteinase $\mathrm{K}, \mathrm{PK}$ ), a broad range binder (ovalbumine) and a negative control (human carbonic anhydrase, HCA) showing reference protein bands (input) and bands of protein pulled-down by biotin- $\left({ }^{\mathbf{m}} \mathbf{Q} \mathbf{Q}_{4}\right)_{8}$ on streptavidin beads or beads alone (non-specific binding). b, Quantitation of the experiment shown in a reported as percentage of input retained on beads coupled to the foldamer. Results are the means of duplicate or triplicate experiments \pm standard deviation. 


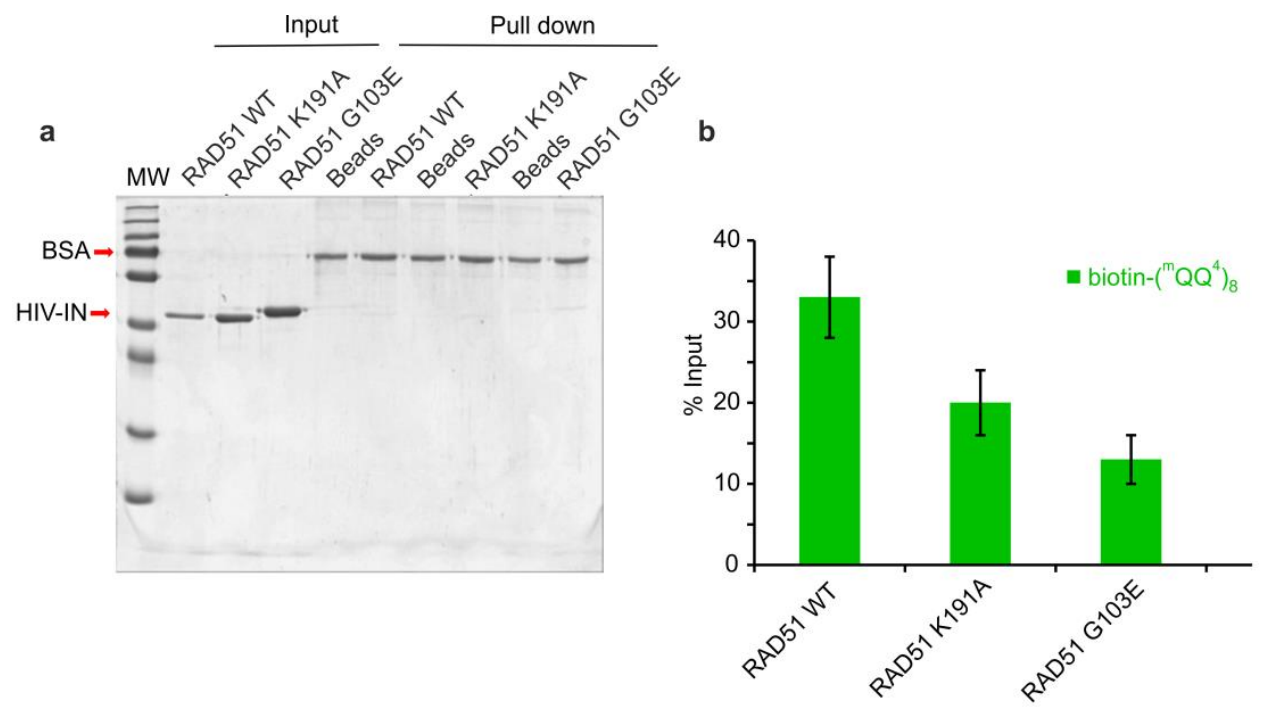

Supplementary Figure 52. a, 12\% SDS-PAGE of RAD51 and its DNA binding-deficient mutants showing reference protein bands (input) and bands of protein pulled-down by biotin- $\left({ }^{\mathbf{m}} \mathbf{Q Q}_{4}\right)_{8}$ on streptavidin beads or beads alone (non-specific binding). b, Quantitation of the experiment shown in a reported as percentage of input retained on beads coupled to the foldamer. Results are the means of duplicate or triplicate experiments \pm standard deviation.

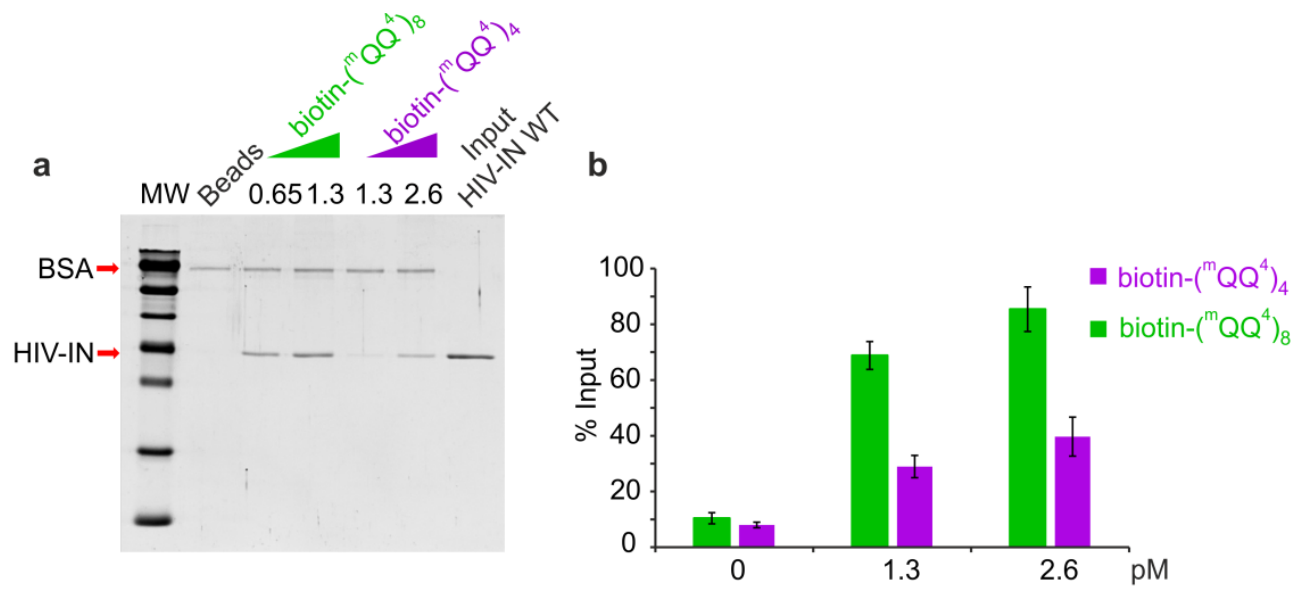

Supplementary Figure 53. a, SDS-PAGE of pull down experiments using HIV-IN and either biotin- $\left({ }^{\mathrm{m}} \mathbf{Q} \mathbf{Q}_{4}\right)_{8}$ or biotin- $\left({ }^{\mathrm{m}} \mathbf{Q} \mathbf{Q}_{4}\right)_{4}$. b, Quantitation of the experiment shown in a reported as percentage of input retained on beads coupled to the foldamer. Results are the means of duplicate or triplicate experiments \pm standard deviation. 
a

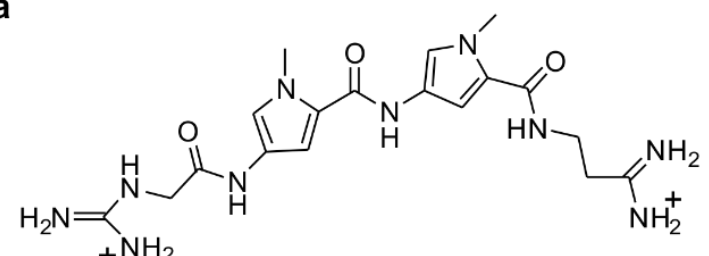

Netropsin

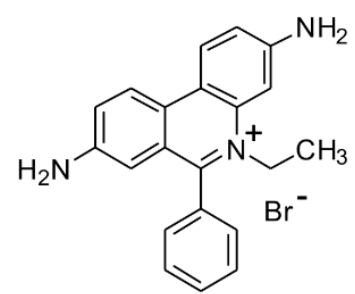

Ethidium bromide<smiles>NCCCCNCCCNCCCN</smiles>

Spermine

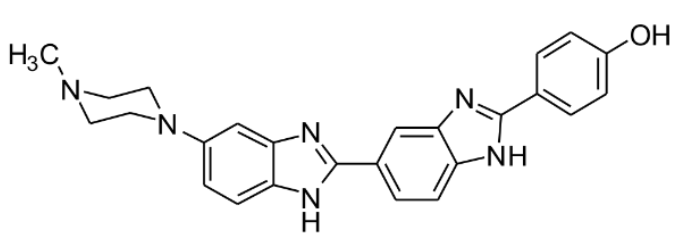

Hoechst 3358

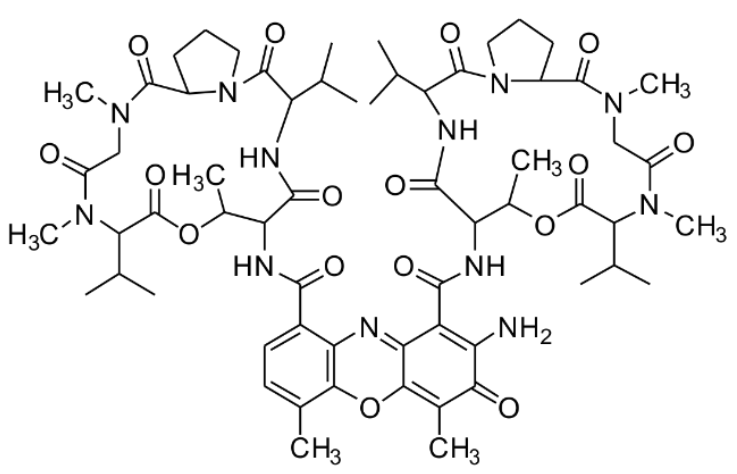

Actinomycin D

Hairpin 1: 5'-biotin-CGAATTCGTCTCCGAATTCG Hairpin 2: 5'-biotin-AAAGCTTTTGTAAAGCTTT

b
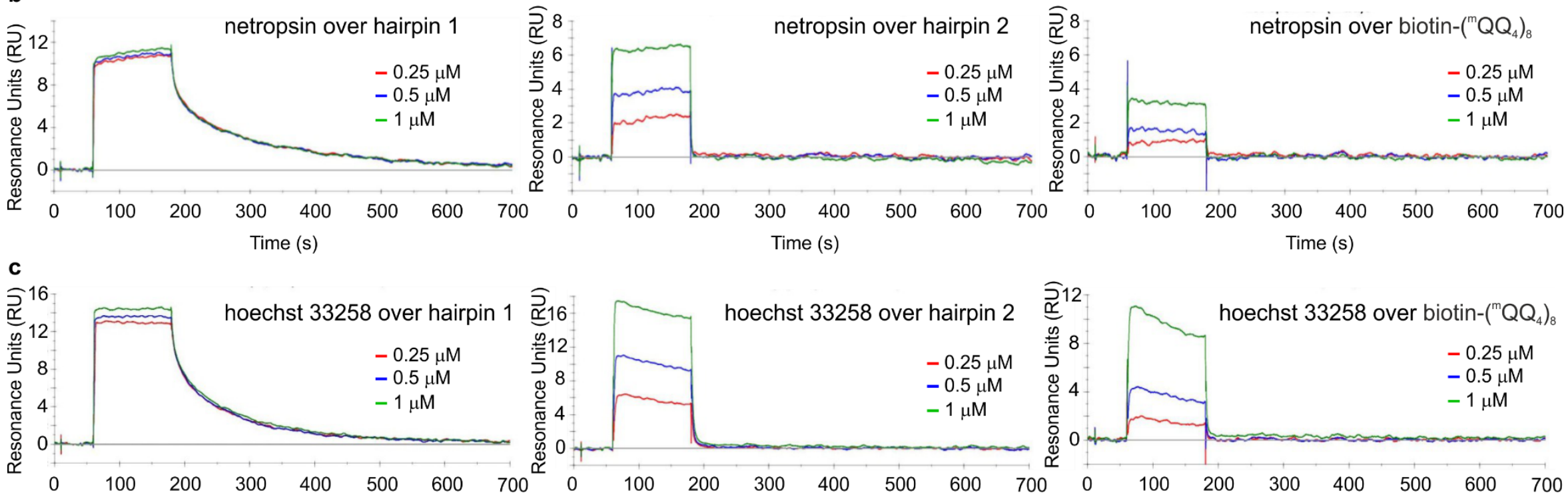
Time (s)

Supplementary Figure 54 ( $\left(1^{\text {st }}\right.$ part $)$ 

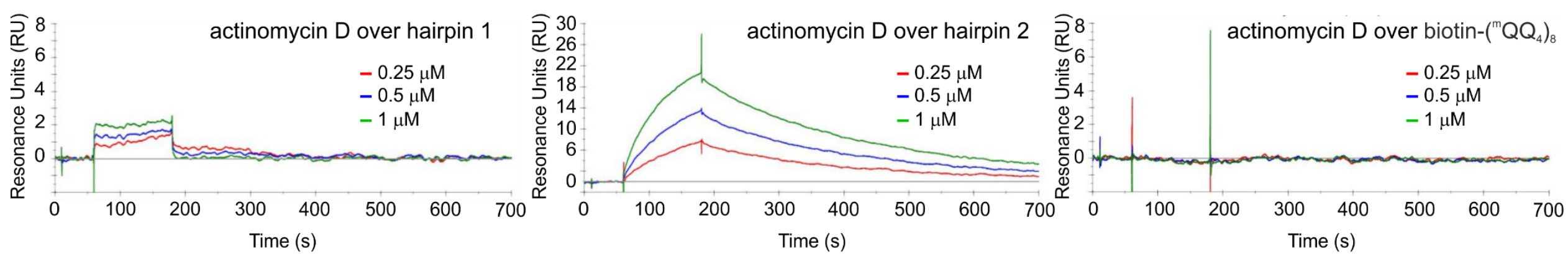

e
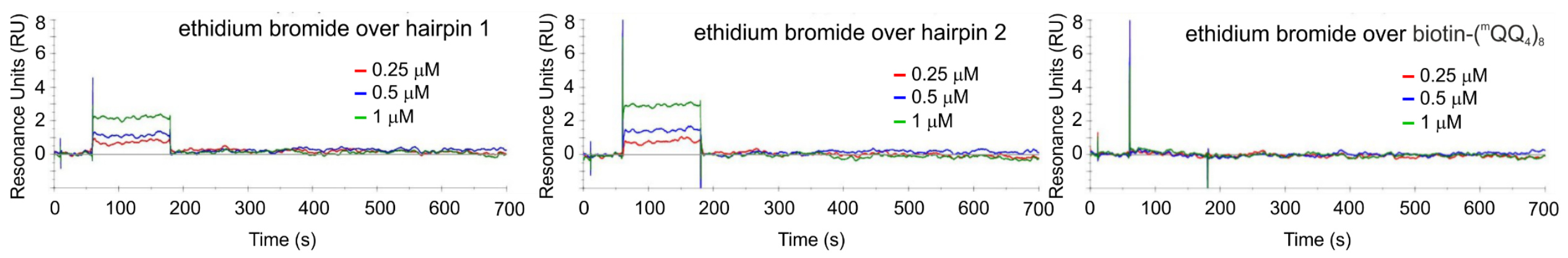

f
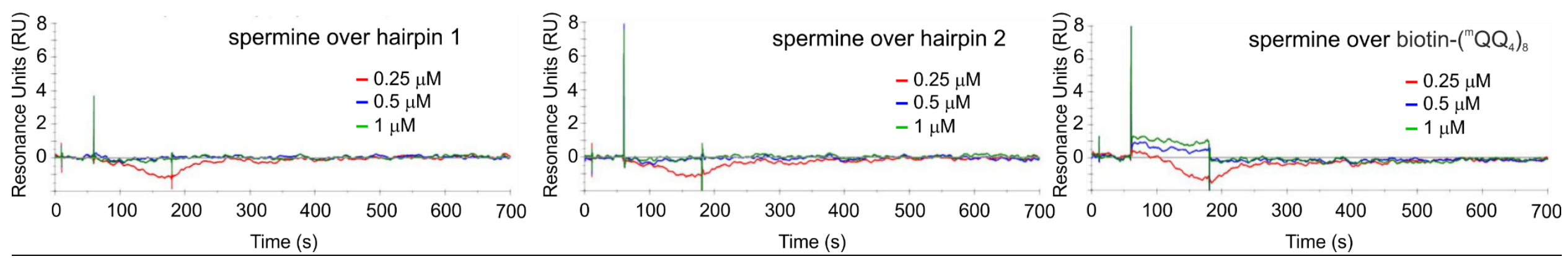

Supplementary Figure 54 (cont.). a, Molecular structures of DNA small ligands and DNA hairpin sequences. b-f, Surface Plasmon Resonance (SPR) sensorgrams of the interaction of netropsin, Hoechst 33258, actinomycin D and spermine with 5'-biotin labeled DNA (hairpin 1 and hairpin 2) and biotin- $\left({ }^{\mathrm{m}} \mathrm{QQ}^{4}\right)_{8}$. For the experiments, the analyte samples were prepared in the HBS-EP running buffer and injected at three concentrations $(0.25,0.5$ and $1 \mu \mathrm{M}$ ) during $2 \mathrm{~min}$ at $20 \mu \mathrm{L} / \mathrm{min}$. 


\section{Supplementary Methods}

\subsection{Nuclear magnetic resonance spectroscopy}

NMR spectra were recorded on four different NMR spectrometers: (1) an Avance II NMR spectrometer (Bruker Biospin) with a vertical 7.05T narrow-bore/ultrashield magnet operating at $300 \mathrm{MHz}$ for ${ }^{1} \mathrm{H}$ observation, $75 \mathrm{MHz}$ for ${ }^{13} \mathrm{C}$ observation and $121.4 \mathrm{MHz}$ for ${ }^{31} \mathrm{P}$ observation by means of a 5-mm direct BBO H/X probe with Z gradient capabilities; (2) a DPX-400 NMR spectrometer (Bruker Biospin) with a vertical 9.4T narrow-bore/ultrashield magnet operating at $400 \mathrm{MHz}$ for ${ }^{1} \mathrm{H}$ observation by means of a $5-\mathrm{mm}$ direct $\mathrm{QNP}{ }^{1} \mathrm{H} /{ }^{13} \mathrm{C} /{ }^{31} \mathrm{P}$ probe with $\mathrm{Z}$ gradient capabilities; (3) an Avance III NMR spectrometer (Bruker Biospin) with a vertical 16.45T narrowbore/ultrashield magnet operating at $700 \mathrm{MHz}$ for ${ }^{1} \mathrm{H}$ observation by means of a 5 -mm TXI ${ }^{1} \mathrm{H} /{ }^{13} \mathrm{C}$ probe with Z gradient capabilities; (4) an Avance III NMR spectrometer (Bruker Biospin) with an 18.8T narrow-bore magnet operating at $800 \mathrm{MHz}$ for ${ }^{1} \mathrm{H}$ observation and $200 \mathrm{MHz}$ for ${ }^{13} \mathrm{C}$ observation by means of a cryoprobe $\mathrm{CP}-\mathrm{TCI}{ }^{1} \mathrm{H} /{ }^{13} \mathrm{C}$ probe with $\mathrm{Z}$ gradient capabilities. Chemical shifts are reported in parts per million (ppm, $\delta$ ) relative to the ${ }^{1} \mathrm{H}$ residual signal of the deuterated solvent used. ${ }^{1} \mathrm{H}$ NMR splitting patterns with observed first-order coupling are designated as singlet $(\mathrm{s})$, broad singlet (bs), doublet (d), triplet (t), quartet (q), multiplet (m), doublet of doublet (dd), doublet of quartet (dq), doublet of triplet (dt) and triplet of doublet (td). Coupling constants $(J)$ are reported in Hertz. Samples were degassed in the case of water soluble foldamers. Data processing was performed with Topspin 2.0 software (Bruker biospin). Complete assignment of deprotected $\left({ }^{\mathrm{m}} \mathrm{QQ}^{4}\right)_{4}{ }^{1} \mathrm{H}$ and ${ }^{13} \mathrm{C}$ nuclei (Supplementary Table S7) in $50 \mathrm{mM}$ ammonium bicarbonate $\mathrm{H}_{2} \mathrm{O} / \mathrm{D}_{2} \mathrm{O}$ $(9: 1 \mathrm{vol} / \mathrm{vol})$ was achieved by using multi-dimensional nuclear magnetic resonance spectroscopy involving a combination of $2 \mathrm{D}{ }^{1} \mathrm{H},{ }^{1} \mathrm{H}-\mathrm{NOESY}$ (800 ms mixing times), $2 \mathrm{D}-{ }^{1} \mathrm{H},{ }^{1} \mathrm{H}-\mathrm{COSY}, 2 \mathrm{D}$ ${ }^{1} \mathrm{H},{ }^{13} \mathrm{C}-\mathrm{HSQC}$, and $2 \mathrm{D}{ }^{1} \mathrm{H},{ }^{13} \mathrm{~N}-\mathrm{HMBC}$.

\subsection{Mass spectrometry}

High resolution mass spectrometry analysis and exact mass measurements. Detection of compounds was performed using a hybrid quadrupole Orbitrap Q-Exactive mass spectrometer controlled by the Excalibur 2.2 Software (Thermo Fisher Scientific, San Jose, USA). A heated electrospray ionization (HESI-II) source was used for ionization of the target compounds in positive and negative ion modes. Instrument calibration in positive mode and negative mode were done within $24 \mathrm{~h}$ to avoid mass shifts in detection respectively with a direct infusion of a LTQ Velos ESI Positive Ion Calibration Solution (88323, Thermo Scientific Pierce) or an ESI Negative Ion Calibration Solution (88324, Thermo Scientific Pierce). The key parameters were as follows: ionization voltage, $+3.9 \mathrm{kV} /-3.3 \mathrm{kV}$; sheath gas pressure, 6.0 arbitrary units; auxiliary gas, 6.0 arbitrary units and capillary temperature, $320^{\circ} \mathrm{C}$. For the compounds of interest, a scan range of $\mathrm{m} / \mathrm{z}$ 500-3000 was chosen. The data were acquired at a resolving power of $70000 \mathrm{FWHM}$ at $\mathrm{m} / \mathrm{z}$ 200. The automatic gain control (AGC) target for a maximum capacity in C-trap was set at $1 \times 10^{6}$ ions for a maximum injection time of $50 \mathrm{~ms}$.

Matrix assisted laser desorption ionization mass spectrometry (MALDI-MS). A saturated solution of 2,4,6-trihydroxyacetophenone (THAP) matrix (Aldrich) was prepared in ethanol solution containing $3 \mathrm{mM}$ ammonium hydroxide. Samples were mixed at equal volume with matrix solution before being loaded on the MALDI plate. Spectra were acquired in positive ion mode on a MALDI TOF-TOF mass spectrometer (Ultraflex III, Bruker, Bremen, Germany) with IS1 set to $20 \mathrm{kV}$, IS2 to $17.05 \mathrm{kV}$, lens to $7.5 \mathrm{kV}$, reflector 1 to $21 \mathrm{kV}$ and reflector 2 to $11 \mathrm{kV}$. The laser was set to an energy level of $30-50 \%$ on the instrument scale. 


\subsection{X-ray crystallography}

Single crystal $\mathrm{X}$-ray diffraction studies. Crystallographic data for fully protected $\operatorname{Boc}\left({ }^{\mathrm{m}} \mathbf{Q Q}{ }^{5}\right)_{4} \mathrm{OBn}$, Boc $\left({ }^{\mathrm{m}} \mathbf{Q} \mathbf{Q}^{4}\right)_{8} \mathrm{OBn}$, and $\operatorname{Boc}\left({ }^{\mathrm{m}} \mathbf{Q Q}^{4}\right)_{8} \mathrm{OTMSE}$ were collected at the IECB X-ray facility (UMS 3033- UMS001). Data were collected at the copper k $\alpha$ radiation $\left(\mathrm{Cu}_{\mathrm{K} \alpha}=1.5418 \AA\right)$ with a partial chi goniometer. Data for Boc $\left({ }^{\mathrm{m}} \mathbf{Q} \mathbf{Q}^{4}\right)_{8} \mathrm{OBn}$ and $\mathrm{Boc}\left({ }^{\mathrm{m}} \mathbf{Q} \mathbf{Q}^{4}\right)_{8} \mathrm{OTMSE}$ were collected on a Rigaku MM007 rotating anode $(0.8 \mathrm{~kW})$ equipped with high flux Osmic Varimax mirrors and a RAPID SPIDER image plate detector. Data for Boc $\left({ }^{\mathrm{m}} \mathbf{Q Q}^{5}\right)_{4} \mathrm{OBn}$ were collected on a Rigaku FRX rotating anode $(3.0 \mathrm{~kW})$ equipped with a Pilatus pixel detector. Crystallographic data for fully protected Boc $\left({ }^{\mathrm{m}} \mathbf{Q Q}{ }^{4}\right){ }_{16} \mathrm{OBn}$ were collected at ESRF facility (FIP BM30A) at a wavelength of $0.81 \AA$. The Rigaku Crystal Clear suite was used to index and integrate the home source data with a multiscan absorption correction. Data collected at the synchrotron were processed with the XDS package (W. Kabsch, Acta Crysallogr. Sect. D-Biol. Crystallogr., D66, 125-132 (2010)). Crystallographic data and refinement parameter are listed in Tables S1-S4.

All structures were solved by the dual space method using SHELXD (Sheldrick, G. M. Acta Crystallogr. Sect. A, 64, 112-122 (2008)) refined by full-matrix least-squares methods using SHELXL2013, both softwares being found within the OLEX2 (Dolomanov, O. V., Bourhis, L. J. Gildea, R. J., Howard, J. A. K. \& Puschmann, H. J. Appl. Cryst. 42, 339-341 (2009)) or SHELXle (Hübschle, C. B., Sheldrick G. M. \& Dittrich, B. J. Appl. Cryst. 44, 1281-1284 (2011)) packages. The SQUEEZE procedure implemented in PLATON (Spek, A. L. J. Appl. Cryst., 36, 7-13 (2003)) was used for all structures in order to treat the regions with highly disordered solvent molecules. The crystals of all four studied molecules never gave high-resolution diffraction patterns, which led to imprecise parts in the electron density map. Such behaviour imposed the utilisation of several constraints and restraints, which will be detailed in the following paragraphs. Moreover, due to the limited resolution of the data, some areas of the electron density maps could not be satisfactory interpreted and some features of the structures of $\operatorname{Boc}\left({ }^{\mathrm{m}} \mathbf{Q} \mathbf{Q}^{4}\right)_{8}$ and $\operatorname{Boc}\left({ }^{\mathrm{m}} \mathbf{Q} \mathbf{Q}^{4}\right)_{16}$ molecules could not be extracted from the measured electron density maps. Especially, some position of ethyl groups of the phosphonate side chains could not be found because multiple positions exist and we decided to model and refine the side chains only when some electronic density could be extracted over the noise in the electron density maps. For example, the section of $F_{\mathrm{o}}$ (blue) electron density maps contoured at the $2.0 \sigma$ level superimposed to an ${ }^{\mathbf{m}} \mathbf{Q}$ monomer $(\mathbf{A})$ and a $\mathrm{Q}^{4}$ monomer $(\mathbf{B})$ of the structure of fully protected $\mathrm{Boc}\left({ }^{\mathrm{m}} \mathbf{Q} \mathbf{Q}^{4}\right){ }_{16} \mathrm{OBn}$ are shown below.

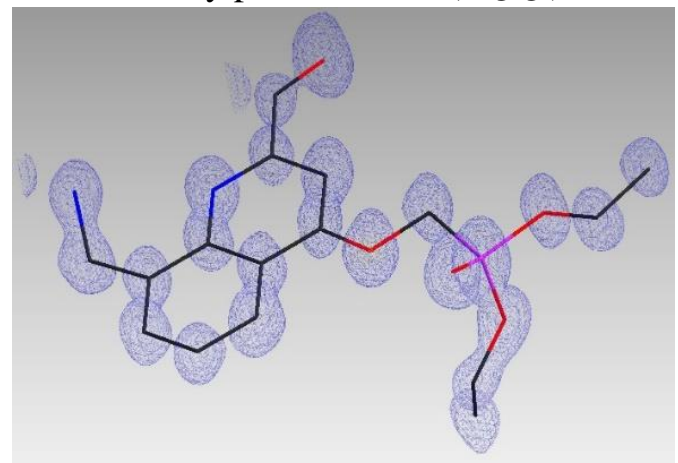

A. sufficient electronic density over $\sigma$ allows to extract positions of the side chain ethyl groups

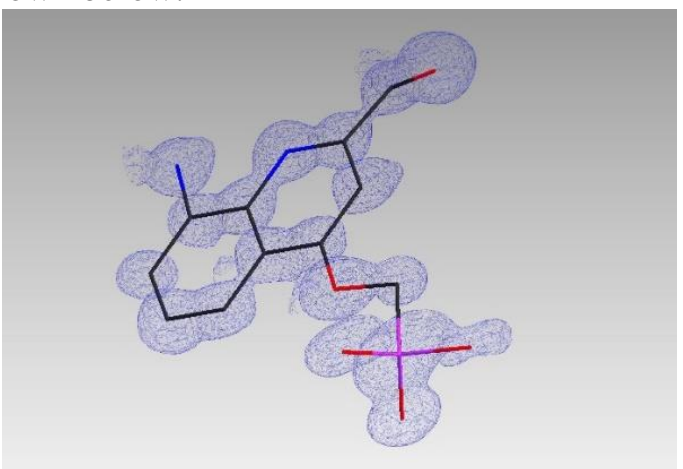

B. insufficient electronic density over $\sigma$ does not allow to extract positions of the side chain ethyl groups

These refinements were performed with geometric limitations like SHELX DFIX and DANG restraints and, in some cases, with isotropic atomic displacement parameters. SHELX SIMU and DELU restraints were used in the refinement strategy, as listed in the cif files. These are restraints on Displacement Parameters that take into account that atoms that are bound to one another move 
similarly, both in direction and amount. Such modelling is efficient at avoiding negative displacement parameters and thus well takes into account the measured electron density. The consequence of this strategy is a view of the side chains in an average position when the information is contained in the data, but side chains that showed too disordered areas and that therefore did not produce any signal above the noise of the electron density maps were squeezed out and do not appear in the model. In all cases where the geometry of the model allowed it, the positions of the $\mathrm{H}$ atoms were calculated from coordinates of the parent atoms and treated according to the riding model during refinement with isotropic displacement parameters, corresponding to 1.2 to 1.5 times the Ueq of the atom they are linked to. The side chain terminal methyl groups were refined, with idealised $\mathrm{H}$ atom positions (HFIX 33).

The best diffraction patterns were obtained for the Boc $\left({ }^{\mathrm{m}} \mathbf{Q} \mathbf{Q}^{5}\right)_{4} \mathrm{OBn}$ foldamer for which all non-H atoms could be modeled from the electron density map and refined with anisotropic atomic displacement parameters and no additional constraints or restraints except some bond and angle restrictions on side chains as described above.

Weaker diffraction patterns associated to larger asymmetric units led us to add more restraints and constraints for $\operatorname{Boc}\left({ }^{\mathrm{m}} \mathbf{Q} \mathbf{Q}^{4}\right)_{8} \mathrm{OBn}$, Boc $\left({ }^{\mathrm{m}} \mathbf{Q} \mathbf{Q}^{4}\right)_{8} \mathrm{OTMSE}$ and $\operatorname{Boc}\left({ }^{\mathrm{m}} \mathbf{Q} \mathbf{Q}^{4}\right)_{16} \mathrm{OBn}$ foldamers. Constraints of type AFIX 116 were systematically applied for quinoline and methyl-quinoline residues to impose a regular and flat aromatic geometry. Additionally, some disordered side chains have been treated using the EADP constraints (equal atomic displacement parameters) to prevent unrealistic displacement parameters. Such restrictions are suitable when the diffraction pattern presents moderate resolution as it decreases the number of refined parameters that is very high for this kind of molecules. In some cases, significant disorder on $\mathrm{sp}^{3}$ carbon atoms did not allowed to extract their positions from the electron density maps and these atoms were not included in the model as explained above. This feature has been observed on the ethyl groups of the phosphonate side chains especially for the Boc $\left({ }^{\mathrm{m}} \mathbf{Q} \mathbf{Q}^{4}\right)_{8} \mathrm{TMSE}$ foldamer for which all ethyl groups of side chain have been removed. Finally, for the largest $\operatorname{Boc}\left({ }^{\mathrm{m}} \mathbf{Q Q}{ }^{4}\right)_{16} \mathrm{OBn}$ foldamer some carbon atoms from $\mathrm{O}-\mathrm{C}-\mathrm{PO}_{3} \mathrm{Et}_{2}$ moiety between $\mathrm{P}$ and $\mathrm{O}$ atoms of some residues were found highly disordered and no density was observed above the noise in the electronic density map. In such case the $\mathrm{C}$ atom position has been geometrically imposed according to the parent $\mathrm{P}$ and $\mathrm{O}$ positions and constrained with isotropic atomic displacement parameters corresponding to the same $\mathrm{U}_{\mathrm{eq}}$ than the $\mathrm{O}$ atom they are linked to.

Applying this strategy gave a satisfactory representation of the main foldamer structure. In all cases the helical structure has been well established (Supplementary Fig. 13). The asymmetric units of $\operatorname{Boc}\left({ }^{\mathrm{m}} \mathbf{Q Q}{ }^{5}\right)_{4} \mathrm{OBn}, \operatorname{Boc}\left({ }^{\mathrm{m}} \mathbf{Q Q}{ }^{4}\right)_{8} \mathrm{OTMSE}$ and $\operatorname{Boc}\left({ }^{\mathrm{m}} \mathbf{Q} \mathbf{Q}^{4}\right)_{16} \mathrm{OBn}$ were found to be constituted by one foldamer molecule while 2 independent molecules are present in the asymmetric unit of $\operatorname{Boc}\left({ }^{\mathrm{m}} \mathbf{Q Q}{ }^{4}\right)_{8} \mathrm{OBn}$. The crystal packing reveals that the cohesion of the network is ensured by $\pi-\pi$ stacking between aromatic quinoline moieties leading to rod like arrangement in one direction, while the 2 other directions implies Van der Waals interactions and hydrogen bonding between side chains that may be mediated by some solvent molecules (Supplementary Figs. 14 and 15).

The Boc- $\left({ }^{\mathrm{m}} \mathrm{QQ}^{4}\right)_{16}$ foldamer has been compared to an idealised 16-base pair B-DNA molecule showing a good match between the phosphonate network of both molecules, the main difference concerning the phosphorus atoms of $\mathrm{Q}^{4}$ units due to a width mismatch of the major groove between the two structures (Supplementary Figs. 16 and 17, Supplementary Table 5). As several molecules of different sizes have been crystallised and solved, it was possible to compare and extract structural variation between the different molecules especially between different $\left({ }^{\mathrm{m}} \mathbf{Q} \mathbf{Q}^{4}\right)_{8}$ sequences from pseudo-polymorphs of $\left({ }^{\mathrm{m}} \mathbf{Q} \mathbf{Q}^{4}\right)_{8}$ foldamer and with both $\mathrm{N}$-terminal and C-terminal $\left({ }^{\mathrm{m}} \mathbf{Q} \mathbf{Q}^{4}\right)_{8}$ parts of the largest $\left({ }^{\mathrm{m}} \mathbf{Q Q} \mathbf{Q}^{4}\right)_{16}$ (Supplementary Fig. 18 and 20, Supplementary Table 6). The structural variability of these compounds is more pronounced in the case of $\operatorname{Boc}\left({ }^{\mathrm{m}} \mathbf{Q} \mathbf{Q}^{5}\right)_{4} \mathrm{OBn}$, in particular regarding the position of the phosphonate groups. Because of the different connecting groups between phosphonates and quinoline rings $\left(-\mathrm{OCH}_{2}-v s .-\mathrm{CH}_{2} \mathrm{CH}_{2}-\right)$, larger deviations of the position 
of the phosphonates from the quinoline ring to which they belong are observed in $\mathbf{Q}^{\mathbf{5}}$ monomers (Supplementary Fig. 19).

The final cif files were checked using IUCR's checkcif algorithm. Due to the characteristics of the crystals mentioned above (large volume fractions of disordered solvent molecules and side chains, weak diffraction intensity, incompleteness of the data and moderate resolution), and due to the choices made for refining some disorder, a number of A-level and B-level alerts remain in the checkcif files. These alerts are explicitly listed below and have been divided into two groups. They are inherent to the data and refinement procedures and do not reflect errors. Rather, they illustrate the limited practicality of the checkcif tool for medium sized molecule crystallography.

GROUP 1 ALERTS

THETM01_ALERT_3_A/B : The value of sine(theta_max)/wavelength is less than expected PLAT088_ALERT_3_A : reasonable Data / parameter ratio

PLAT026_ALERT_3_B : Check for weak data

PLAT029_ALERT_3_A/B_diffrn_measured_fraction_theta_full Low

PLAT082/84_ALERT_3_A/B High R1 or wR2 Value

PLAT911_ALERT_3_B Missing \# FCF Refl Between THmin \& STh/L=0.600

PLAT934_ALERT_3_A/B (Iobs-Icalc)/SigmaW > 10 for some reflections

PLAT020_ALERT_3_B The value of Rint is greater than expected

All these alerts in fact point to the same and unique problem which is the overall weak quality of the data and refinement statistics if compared to that expected for small molecule structures from highly diffracting crystals. They are inherent to the best quality crystals that can be grown from large molecules. Large units cells, especially when several independent molecules are found in the asymmetric unit (for example for $\operatorname{Boc}\left({ }^{\mathrm{m}} \mathbf{Q} \mathbf{Q}^{4}\right)_{8} \mathrm{OBn}$ ), high fraction volume of disordered solvent and side chain content contribute to low average statistics. Data collection using synchrotron radiation (for Boc $\left({ }^{\mathrm{m}} \mathbf{Q} \mathbf{Q}^{4}\right){ }_{16} \mathrm{OBn}$ ) brings the benefit of improving diffraction intensity and collecting at higher resolution, but it also has drawbacks such as radiation damage or beamline data collection geometry which may preclude to collect at high $\theta_{\max }$ values and which also limits data completeness as most beam lines are equipped with a single axis goniometer.

GROUP 2 ALERTS

PLAT201_ALERT_2_A/B : Test for Isotropic non-H Atoms in Main Residue(s)

PLAT213_ALERT_2_A / B : Test ratio adp max/min

PLAT222_ALERT_3_A : Uiso(max)/Uiso(Min) range for $\mathrm{H}$ atoms in non-solvent

PLAT234_ALERT_4_A and B : Hirshfeld Rigid-Bond Test

PLAT360_ALERT_2_B : short or long C $-\mathrm{C}$ bond (Angstrom Difference)

PLAT241_ALERT_2_B : unusually high U(eq) as compared with bonded neighbors

PLAT242_ALERT_2_B : unusually Low U(eq) as compared with bonded neighbors

PLAT230_ALERT_2_B :Hirshfeld Rigid-Bond Test

PLAT340_ALERT_3_B : Bond Precision for C-C in Light Atom Structures

PLAT410_ALERT_2_A : Test for short non-bonding intra H..H contacts

PLAT417_ALERT_2_A and B : Test for short non-bonding inter D-H..H-D contacts

These A and B alerts are related to geometrical and atomic displacement parameters problems, all concerning side chains, that result from the way these have been treated (see above) when they have not been squeezed out. Many of these alerts are redundant: for example, a "unusually high $\mathrm{U}(\mathrm{eq})$ as compared with bonded neighbors" generally goes with one or several "unusually low $\mathrm{U}(\mathrm{eq})$ as compared with bonded neighbors". 


\section{4 pKas measurement of phosphonate oligomers}

With the aim of investigating the charge state of the phosphonate oligomers at the neutral $\mathrm{pH}$ required for biological assays, we have synthesized model phosphonate monomer S53 which represents a simple system for the evaluation of $\mathrm{pKa}$ values of a single phosphonic acid to be compared with a molecule bearing several phosphonic acids. Compound $\mathbf{S 5 3}(25 \mathrm{mM})$ was titrated with $\mathrm{NaOH}$ (at a concentration of $250 \mathrm{mM}$ ) and $\mathrm{pH}$ values were recorded after stirring the solution for 3 min using a Consort C830 pH meter. Supplementary Figure 36a shows the titration curve where two equivalence points are clearly visible and two pKas can be measured at 1.65 and 6.28. This data are in agreement with literature reports (S. Iyer et al., Bioorg. Med. Chem. Lett. 14, 59315935 (2004); C. U. Kim et al., J. Med. Chem. 33, 1207-1213 (1990)) where pKa2 values of several aryloxymethyl phosphonic acids have been estimated.

Similarly, the acidic form of $\left({ }^{\mathrm{m}} \mathrm{QQ}_{4}\right)_{8}$ was obtained after passing it on an ion exchange column and titrated with $\mathrm{NaOH}$ as shown in Supplementary Figure 36b. The proximity between the 16 phosphonate groups results in a different pattern. The first $\mathrm{pKa}$ is raised to an average 2.4 and the second pKa covers a range of values centred above 8.5. Obviously, the increasing negative charge density at the surface of the helix progressively shifts $\mathrm{pKa}$ values making further deprotonation more difficult than in a monophosphonic acid acid such as compound S53. The actual charge state at $\mathrm{pH} 7$ is thus not -32 . The phosphonate nevertheless retain their capacity to undergo double deprotonation upon binding to a DNA-binding protein.

\subsection{Surface plasmon resonance (SPR)}

Binding experiments were performed to determine whether the foldamers could be recognized by small molecule ligands of double stranded DNA. SPR experiments were performed at $25^{\circ} \mathrm{C}$ with a Biacore $^{\mathrm{TM}}$ T200 apparatus (Biacore ${ }^{\mathrm{TM}}$, GE Healthcare Life Sciences, Uppsala, Sweden). The experiments were performed on CM5 S Series sensor chips $\left(\right.$ Biacore $^{\mathrm{TM}}$ ) coated with 2900-3300 resonance units (RU) of streptavidin (Roche Applied Sciences, Roche Diagnostics, Meylan, France) using the Biacore ${ }^{\mathrm{TM}}$ amine-coupling kit and milliQ water in running buffer. 100-200 RU of 5 ' biotinylated DNA hairpin sequences (biotin-CGAATTCGTCTCCGAATTCG and biotinAAAGCTTTTGTAAAGCTTT, with the hairpin loop sequence underlined, ChemGenes Corporation, Wilmington, MA USA) and biotin- $\left({ }^{\mathrm{m}} \mathrm{QQ}_{4}\right)_{8}$ were immobilized by injecting solutions prepared at 25-100 nM in HBS-EP (Biacore ${ }^{\mathrm{TM}}$ ) running buffer. One flow-cell was left blank and used as a reference. For the experiments, the analyte samples (DNA small ligands as netropsin, Hoechst 33258, actinomycin D, ethidium bromide and spermine, from Sigma Aldrich) were dissolved in the running buffer and injected at three concentrations $(0.25,0.5$ and $1 \mu \mathrm{M})$ during 2 $\min$ at $20 \mu \mathrm{L} / \mathrm{min}$. The regeneration of the functionalized surface was achieved with a $30 \mathrm{sec}$ pulse of $25 \mathrm{mM} \mathrm{NaOH}$. The sensorgrams were double-referenced using BiaEval 4.1 (Biacore ${ }^{\mathrm{TM}}$ ). No point were removed.

\subsection{Biological assays}

Top1-catalyzed relaxation assays. Top1 catalytic activity was assessed in plasmid DNA relaxation assays according to the specifications of the supplier (Topogen, Colombus, $\mathrm{OH}$ ) with minor modifications. For each reaction, $100 \mathrm{ng}$ of (-)-pcDNA3.1 supercoiled plasmid was incubated with 1 unit of purified human recombinant Top1 in 1X reaction buffer $(10 \mathrm{mM}$ Tris- $\mathrm{HCl}$, pH 7.9, $1 \mathrm{mM}$ EDTA, $150 \mathrm{mM} \mathrm{NaCl}, 0.1 \%$ bovine serum albumin, $0.1 \mathrm{mM}$ spermidine, $5 \%$ glycerol). Reactions were performed in $10 \mu \mathrm{L}$ final volume for $15 \mathrm{~min}$ at $20^{\circ} \mathrm{C}$ and stopped by the addition of $1 \mu \mathrm{L}$ of $5 \%$ SDS and $3 \mu \mathrm{L}$ of BlueJuice ${ }^{\mathrm{TM}}$ Gel Loading Buffer (Life Technologies, Saint-Aubin, France). Reaction mixtures were then electrophoresed in $1 \%$ agarose gels for $3 \mathrm{~h}$ at 75 Volts in $1 \mathrm{X}$ TAE buffer. Gels were then incubated in $1 \mathrm{X}$ TAE staining solution containing 2 $\mu \mathrm{g} / \mathrm{mL}$ ethidium bromide and destained by incubation in fresh $1 \mathrm{X}$ TAE buffer containing $1 \mathrm{mM}$ 
$\mathrm{MgSO}_{4}$ for $30 \mathrm{~min}$. Reaction products were then visualised by UV-transillumination and supercoiled DNA was quantified using image $\mathrm{J}$ and plotted as a function of foldamer concentration. Top2-catalyzed decatenation assays. Top2 catalytic activity was assessed by the decatenation assay as described by the supplier (Topogen, Colombus). Each reaction was performed in $20 \mu \mathrm{L}$ final volume containing $200 \mathrm{ng}$ of catenated kinetoplast DNA (kDNA) from Trypanosoma (Topogen, Colombus, $\mathrm{OH}$ ) as a substrate, $40 \mathrm{mM}$ Tris/ $\mathrm{HCl} \mathrm{pH} \mathrm{7.4,} 10 \mathrm{mM} \mathrm{MgCl}, 0.5 \mathrm{mM}$ EDTA, $100 \mathrm{mM} \mathrm{KCl}, 0.5 \mathrm{mM}$ dithiotreitol, and $1 \mathrm{mM}$ ATP. Reactions were initiated by the addition of kDNA and 1 unit of purified human Top2 $\alpha$ and incubated for 30 min at $37{ }^{\circ} \mathrm{C}$. Reactions were stopped by the addition of $2 \mu \mathrm{L}$ of 10X stop buffer ( $5 \%$ sarkosyl, $30 \%$ glycerol and $0.125 \mathrm{mg} / \mathrm{ml}$ of bromophenol blue) and electrophoresed on a 1\% agarose gel for $45 \mathrm{~min}$ at $50 \mathrm{~V}$. Visualization and quantification of open circular (OC) and closed circular (CC) reaction products were performed as described for Top1 assays.

HIV-IN-catalyzed integration assays. HIV-1 integrase was purified either from bacteria using the same procedure as described for PFV enzyme (Valkov, E., Gupta, S. S., Hare, S., Helander, A., Roversi, P., McClure, M. \& Cherepanov, P. Functional and structural characterization of the integrase from the prototype foamy virus. Nucleic Acids Res. 37, 243-255 (2009)) or from yeast as previously reported (Lesbats, P., Botbol, Y., Chevereau, G., Vaillant, C., Calmels, C., Arneodo, A., Andreola, M. L., Lavigne, M. \& Parissi, V. Functional coupling between HIV-1 integrase and the SWI/SNF chromatin remodeling complex for efficient in vitro integration into stable nucleosomes. PLoS Pathog 7, e1001280 (2011)). Both pBSK-Zeo target and HIV-1 donor DNA were described previously (Faure, A., Calmels, C., Desjobert, C., Castroviejo, M., Caumont-Sarcos, A., TarragoLitvak, L., Litvak, S., Parissi, V. HIV-1 integrase crosslinked oligomers are active in vitro. Nucleic Acids Res. 33, 977-986 (2005)). Standard concerted integration reactions were optimised from conditions described previously (Lesbats, P., Metifiot, M., Calmels, C., Baranova, S., Nevinsky, G., Andreola, M. L. \& Parissi, V. In vitro initial attachment of HIV-1 integrase to viral ends: control of the DNA specific interaction by the oligomerization state. Nucleic Acids Res. 36, 7043-7058 (2008)) in order to allow efficient catalysis of full site integration reaction in absence of other cellular cofactors. For this purpose we used a 5'-end-labeled donor DNA (10 ng) and circular target DNA plasmids (50 ng) and purified INs (typically $200 \mathrm{nM}$ ) previously diluted into $1 \mu \mathrm{M}$ in $1 \mathrm{M}$ $\mathrm{NaCl}, 20 \mathrm{mM}$ HEPES $1 \mathrm{M} \mathrm{pH} 7,10 \mathrm{mM}$ DTT for 30 minutes on ice. Then $200 \mathrm{nM}$ IN were incubated 30 minutes on ice with $10 \mathrm{ng}$ of donor DNA and $50 \mathrm{ng}$ of acceptor plasmid in $5 \mu \mathrm{L}$ final volume. The reaction was then started by adding $5 \mu \mathrm{L}$ of the reaction buffer (final concentrations $100 \mathrm{nM} \mathrm{IN}, 15 \%$ DMSO, $8 \%$ PEG, $10 \mathrm{mM} \mathrm{MgCl}$, $20 \mu \mathrm{M} \mathrm{ZnCl}_{2}, 100 \mathrm{mM} \mathrm{NaCl}, 10 \mathrm{mM}$ DTT). After the reaction, integration products were loaded onto a $1 \%$ agarose gel. The gel was then dried and autoradiographed. Quantification of the integration activity was performed using the Image $\mathbf{J}$ software with the following procedure: the bands corresponding to the free substrate (S), the donor/donor (d/d), linear FSI (FSI) and circular HSI+FSI (HSI+FSI) were quantified. The percentage of HSI+FSI integration activity was calculated as $(\mathrm{HSI}+\mathrm{FSI}) /[(\mathrm{FSI})+(\mathrm{HSI}+\mathrm{FSI})+(\mathrm{d} / \mathrm{d})+(\mathrm{S})] \times \mathrm{x} 100$. Percentage of FSI integration activity was determined as $(\mathrm{FSI}) /[(\mathrm{FSI})+(\mathrm{HSI}+\mathrm{FSI})+(\mathrm{d} / \mathrm{d})+(\mathrm{S})] \times 100$. The global FSI activity was estimated from the amount of linear FSI products which has previously been shown to be representative of the circular FSI form.

FEN1 activity assay. Human FEN1 was purchased from Trevigen, Gaithersburg. FEN1 substrate was generated as follows: 100 pmoles of 5, radiolabeled FODN (GGACTCTGCCTCAAGACGGTAGTCAACGTG) was hybridised to 100 pmoles of Flap ODN (GATGTCAAGCAGTCCTAACTTTGAGGCAGAGTCC) and 100 pmoles of Bridge ODN (CACGTTGACTACCGTC). The FEN1 substrate was incubated with 1 unit of FEN1 and increasing concentration of foldamer for $1 \mathrm{~h}$ at $37{ }^{\circ} \mathrm{C}$ in $15 \%$ DMSO, $8 \% \mathrm{PEG}, 10 \mathrm{mM} \mathrm{MgCl}$, $20 \mu \mathrm{M} \mathrm{ZnCl}, 100 \mathrm{mM} \mathrm{NaCl}, 10 \mathrm{mM}$ DTT. Reaction products were precipitated after deproteinization, loaded on a $12 \%$ polyacrylamide denaturating gel and separated for $3 \mathrm{~h}$ at 2000 
volts. After migration the gel was autoradiographed and the bands were quantified using the Image J software.

Benzonase $^{\circledR}$ DNA-cleavage assay. Following the specifications of the supplier, benzonase degradation assay was carried out on $16 \mathrm{~T}$ and $\left({ }^{\mathrm{m}} \mathrm{QQ}^{4}\right)_{8}$. Reactions used 0.5 or $1 \mu \mathrm{L}$ of Benzonase (Sigma Aldrich, Saint-Louis Missouri, USA) in the presence of $1 \mu \mathrm{g}$ of $\left({ }^{\mathrm{m}} \mathrm{QQ}^{4}\right)_{8}, 1 \mu \mathrm{g}$ of poly $\left(\mathrm{dT}_{16}\right)$ (Sigma Aldrich) or $1 \mu \mathrm{g}$ of genomic DNA. Substrates were incubated during $1 \mathrm{~h}$ at $37{ }^{\circ} \mathrm{C}$ in Benzonase reaction buffer ( $20 \mathrm{mM}$ Tris- $\mathrm{HCl}$ pH 8.3, $0.2 \mathrm{mM} \mathrm{MgCl}, 20 \mathrm{mM} \mathrm{NaCl})$ and reactions were stopped by freezing samples at $-80{ }^{\circ} \mathrm{C}$. Samples were loaded on $15 \%$ acrylamide gel and stained after migration by « Stains All ».

Nuclease S1 activity. The inhibition of Nuclease S1 activity by $\left({ }^{\mathrm{m}} \mathrm{QQ}^{4}\right)_{8}$ was tested based on a method developed according to the specifications of the supplier. Reactions used $5 \mu \mathrm{g}$ of single stranded salmon sperm DNA, 2 units of $S_{1}$ Nuclease (Sigma Aldrich) in the absence or presence of $30 \mu \mathrm{M}, 20 \mu \mathrm{M}$ and $10 \mu \mathrm{M}$ of $\left({ }^{\mathrm{m}} \mathrm{QQ}^{4}\right)_{8}$. Substrates were incubated for $30 \mathrm{~min}$ at $37^{\circ} \mathrm{C}$ in $\mathrm{S} 1 \mathrm{Nuclease}$ reaction buffer $\left(40 \mathrm{mM}\right.$ sodium acetate $\mathrm{pH} 4.5,0.3 \mathrm{M} \mathrm{NaCl}$ and $\left.2 \mathrm{mM} \mathrm{ZnSO}_{4}\right)$ and reactions were stopped by adding $1 \mu \mathrm{L}$ of $0.5 \mathrm{M}$ EDTA and heating at $70{ }^{\circ} \mathrm{C}$ for $10 \mathrm{~min}$. Samples were loaded on 5\% PAGE and electrophoresed. Migration was done in TAE 1X during $30 \mathrm{~min}$ at $35 \mathrm{~mA}$. Gel was stained by «Stains All » during 30 min and destained in water under UV light.

DNAse 1 assay. The inhibition of enzymatic activity of DNAse 1 by $\left({ }^{\mathrm{m}} \mathrm{QQ}^{4}\right)_{8}$ was tested according to the specifications of the supplier. Reactions used $100 \mathrm{ng}$ of double stranded plasmid pcDNA3.1, 1 unit of Dnase I (Thermo Scientific) in the absence or presence of $50 \mu \mathrm{M}, 25 \mu \mathrm{M}, 10 \mu \mathrm{M}$ and 5 $\mu \mathrm{M}$ of $\left({ }^{\mathrm{m}} \mathrm{QQ}^{4}\right)_{8}$. Substrates were incubated for $10 \mathrm{~min}$ at $37^{\circ} \mathrm{C}$ in DNAse I reaction buffer $(20 \mathrm{mM}$ Tris- $\mathrm{HCl} \mathrm{pH} \mathrm{8.3,} 2 \mathrm{mM} \mathrm{MgCl} 2$ ) and reactions were stopped by adding $1 \mu \mathrm{L}$ of $0.5 \mathrm{M}$ EDTA and heating at $70{ }^{\circ} \mathrm{C}$ for $10 \mathrm{~min}$. Samples were loaded on $1 \%$ agarose gel containing Ethidium bromide or on 5\% acrylamide gel and stained after migration by « Stains All ».

Gel shift and filter binding assays. $\mathrm{dT}-\left({ }^{\mathrm{m}} \mathrm{QQ}^{4}\right)_{8}$ was synthesised as described in section 2 . It was radiolabeled into $\mathrm{dT}^{\mathrm{P} 32}-\left({ }^{\mathrm{m}} \mathrm{QQ}^{4}\right)_{8}$ using $25 \mu \mathrm{ci}$ of gamma ATP and 1 unit of T4 DNA kinase for $1 \mathrm{~h}$ at $37{ }^{\circ} \mathrm{C}$. HIV1-IN (0-175 pmole) was incubated 20 minutes at room temperature with 1 pmole of radiolabeled $\mathrm{T}^{\mathrm{P} 32}-\left({ }^{\mathrm{m}} \mathrm{QQ}^{4}\right)_{8}$, or a short double stranded 8-mer ODN containing the U3 viral ends sequence or a short double stranded 8-mer ODN containing a randomised sequence in $15 \%$ DMSO, $8 \%$ PEG, $10 \mathrm{mM} \mathrm{MgCl} 2,20 \mu \mathrm{M} \mathrm{ZnCl}_{2}, 100 \mathrm{mM} \mathrm{NaCl}, 10 \mathrm{mM}$ DTT. Reaction mixtures were then either loaded on non-denaturating 12\% polyacrylamide gel and electrophoresed for $6 \mathrm{~h}$ at 500 volts or filtered on nitrocellulose filters. After migration, the gel was autoradiographed. The filters were washed three times with PBS and counted using a Wallac 1409 liquid scintillation counter.

DNA/HIV-IN complex quantification by UV cross-linking was carried out as previously described (Engelman, A., Hickman, A. B., Craigie, R. The core and carboxy-terminal domains of the integrase protein of HIV type 1 each contribute to nonspecific DNA binding. J. Virol. 68, 5911 (1994)).

Pull-down experiments. Purified recombinant proteins ( $3 \mu \mathrm{L}$ of a $4 \mu \mathrm{M}$ solution) were incubated with biotinylated foldamers (0.65-2.6 pmoles) in 10 $\mu \mathrm{L}$ of interaction buffer (50mM HEPES, pH7.5; $1 \mu \mathrm{g} / \mathrm{ml} \mathrm{BSA}$; $1 \mathrm{mM}$ DTT; $0.1 \%$ Tween $20 ; 10 \%$ glycerol; and 50 to $240 \mathrm{mM} \mathrm{NaCl}$ ) for $20 \mathrm{~min}$ on ice and then for $30 \mathrm{~min}$ at room temperature. A $12.5 \mu \mathrm{L}$ aliquot of DynabeadsMyOne Streptavidin T1 (Invitrogen, ref. 65601) was then added to a total volume of $300 \mu \mathrm{L}$ interaction buffer and incubated at room temperature for $1 \mathrm{~h}$ under rotation. The beads were washed three times with $300 \mu \mathrm{l}$ interaction buffer, and the precipitated products were resuspended in $10 \mu 1$ of Laemmli buffer, after which they were separated on a $12 \%$ gel via SDS-PAGE. Interacting proteins were detected by direct gel staining with colloidal blue.

Effects of foldamers on cell growth. Human HCT116 colon cancer cells or HEK293 human embryonic kidney cells were purchased from ATCC and were respectively grown under a $5 \% \mathrm{CO}_{2}$ atmosphere in RPMI and DMEM media supplemented with $10 \%$ foetal calf serum. For cytotoxicity assays, 1,500 cells were seeded per well of a 96-well plate. The day after, cells were washed with PBS and incubated with $0,0.1$ or $1 \mu \mathrm{M}$ of foldamer in serum-free medium. When assessing the 
effect of a transfection reagent, PULSin ${ }^{\mathrm{TM}}$ (Ozyme, Saint Quentin Yvelines, France) was added $(1.2 \mu \mathrm{L}$ per well) together with the foldamer. Incubation typically lasted $4 \mathrm{~h}$. The medium was then replaced by fresh complete medium and incubated for $72 \mathrm{~h}$ and cell growth was measured using the Sulforhodamine B assay according to standard procedures.

Assessment of HIV-1 infectivity inhibition. Human Embryonic Kidney cells (HEK293T) were used for HIV-1 infectivity inhibition. Lentiviral transductions were performed using pRRLsinPGK-eGFP-WPRE VSV-G pseudotyped lentiviral vectors derived from HIV-1 as previously described (Cosnefroy, O., Tocco, A., Lesbats, P., Thierry, S., Calmels, C., Wiktorowicz, T. Stimulation of the human RAD51 nucleofilament restricts HIV-1 integration in vitro and in infected cells. J. Virol., 86, 513-256 (2012)) in the presence of increasing concentrations of foldamer. An optimized multiplicity of infection (MOI) of 1 was used, which resulted in 25-35\% of the cells containing one copy of proviral DNA as determined before. Fluorescence was quantified 10 days post-transduction by counting 10,000 cells on a FACSCalibur flow cytometer (Becton-Dickinson, San Jose, CA, USA). HIV-1 DNA species were quantified at 24, 48 and 72 hours post-transduction as previously described (Munir, S., Thierry, S., Subra, F., Deprez, E. \& Delelis, O. Quantitative analysis of the time-course of viral DNA forms during the HIV-1 life cycle. Retrovirology, 10, 87 (2013)). The total and integrated HIV-1 DNA levels were determined as copy numbers per $10^{6}$ cells. Integrated cDNA and 2-LTR circles were expressed as a percentage of the total viral DNA.

\subsection{Polyanions sample preparation}

Sample preparation of the polyanions tested for Top 1 and HIV integrase inhibition proceeded as follows. Heparin was purchased from SERVA Electrophoresis GmbH (lot No. 160563), dermatan sulphate from SERVA Electrophoresis GmbH (lot No. 090821), heparan sulphate from Iduron (lot No. 1 BN1), and polyphosphate medium side chain (from Kerafast, lot No. 20141104a). Contrary to the foldamers, these polymers represent mixtures of various chains with undefined length, composition, and number of negative charges. In order to compare and possibly quantify their inhibition activities, we have considered an average molecular weight that corresponds to an expected average 16 negative charges. For the composition of polysaccharides (heparin, dermatan sulphate, and heparan sulphate), the most common disaccharide unit was considered and variations were neglected. The same concentration of this segment bearing 16 negative charges was used for all the samples. The formula and molecular weighs are in Supplementary Table 8. 


\subsection{Methods for chemical synthesis}

All reactions that required anhydrous conditions were carried out under a dry nitrogen atmosphere. Commercial reagents were purchased from Sigma-Aldrich or Alfa-Aesar and were used without further purification unless otherwise specified. Commercially available diethyl (hydroxymethyl) phosphonate was purified by flash chromatography with EtOAc as an eluent. Tetrahydrofuran (THF) and dichloromethane (DCM) were dried over alumina columns; chloroform, triethylamine and $N, N$-diisopropylethylamine (DIPEA) were distilled over calcium hydride $\left(\mathrm{CaH}_{2}\right)$ prior to use. Reactions were monitored by thin layer chromatography (TLC) on Merck silica gel 60-F254 plates and observed under UV light. Column chromatography purifications were carried out on Merck GEDURAN Si60 $(40-63 \mu \mathrm{m})$. HPLC-quality acetonitrile $\left(\mathrm{CH}_{3} \mathrm{CN}\right)$ and MilliQ water were used for reverse phase HPLC analyses and purification. Two different approaches were used depending on the compounds to be analyzed. Purity of protected oligomers and completeness of $\mathrm{C}$ and $\mathrm{N}$ termini deprotection was performed on JASCO AS-2055 chromatography system with Nucleodur C8 column (Machery Nagel, 4.6 x $150 \mathrm{~mm}, 5 \mu \mathrm{m})$ using mobile phase composed of $0.1 \%(\mathrm{vol} / \mathrm{vol})$ TFA in water (solvent A) and $0.1 \%$ TFA in acetonitrile (solvent B) and UV detection was carried out with multichannel UV/VIS detector JASCO UV-2077 at $214 \mathrm{~nm}, 254 \mathrm{~nm}$ and $300 \mathrm{~nm}$. Completeness of phosphonate deprotection and purity of fully deprotected oligomers were checked on Varian Pursuit C18 column $(4.6 \times 250 \mathrm{~mm}, 5 \mu \mathrm{m})$ using a gradient of solvent A and solvent B that were prepared as follows: a stock $50 \mathrm{mM}$ aqueous triethyl-ammonium acetate buffer solution at $\mathrm{pH} 8.7$ was prepare by dissolving $3 \mathrm{~mL}$ of glacial acetic acid in $950 \mathrm{~mL}$ water and, while mixing, adding freshly distilled triethylamine $(6.5 \mathrm{~mL})$. After adjusting the $\mathrm{pH}$ to 8.7 with trimethylamine, the volume was finally adjusted to $1 \mathrm{~L}$ with water. Solvent A was prepared by dilution of the stock buffer solution with water $1: 3(\mathrm{vol} / \mathrm{vol})$ to a final concentration of $12.5 \mathrm{mM}$ triethyl-ammonium acetate, $\mathrm{pH}$ 8.7, in water. Solvent B was prepared by dilution of the stock buffer solution with acetonitrile $1: 3(\mathrm{vol} / \mathrm{vol})$ to a final composition of $12.5 \mathrm{mM}$ triethyl-ammonium acetate, $\mathrm{pH} 8.7$, in water:acetonitrile $3: 1 \mathrm{vol} / \mathrm{vol}$. UV detection was carried out at $240 \mathrm{~nm}, 215 \mathrm{~nm}$, and $254 \mathrm{~nm}$ using a diode array detector. Semi-preparative scale purification of water soluble oligomers were performed on a Varian Pursuit C18 column $(21.4 \times 250 \mathrm{~mm}, 5 \mu \mathrm{m})$ equipped with a precolumn, using a gradient of solvent A and solvent B prepared as above. UV detection was carried out at 240 nm.

\subsubsection{Synthesis of monomers}

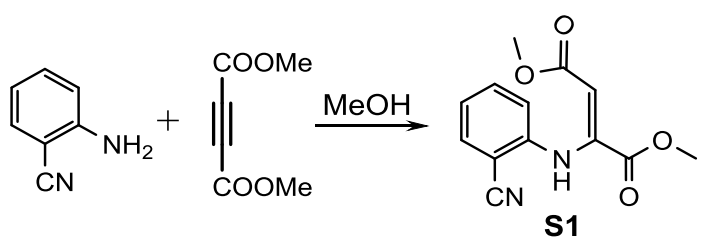

Dimethyl 2-((2-cyanophenyl)amino)fumarate (S1). (N. D. Heindel, T. A. Brodof, J. E. Kogelschatz, J. Heterocyclic Chem. 3, 222 (1966)) To a solution of 2-cyanoaniline (41.5 g, 352 $\mathrm{mmol})$ in $400 \mathrm{~mL}$ of methanol was added dimethyl acetylenedicarboxylate $(50 \mathrm{~g}, 352 \mathrm{mmol})$. The flask was equipped with a reflux condenser and heated to reflux with stirring for $48 \mathrm{~h}$. The solution was then cooled to room temperature and placed at $+4{ }^{\circ} \mathrm{C}$ overnight, then at $-18{ }^{\circ} \mathrm{C}$ for $24 \mathrm{~h}$. The resulting crystals were collected by filtration, washed with cold methanol and dried under vacuum to yield the product $\mathbf{S 1}$ as a yellow crystalline solid (104.0 g, 76\%). The filtrate was concentrated to $120 \mathrm{~mL}$, seeded with crystals and placed at $-18{ }^{\circ} \mathrm{C}$ for $24 \mathrm{~h}$. A second batch of crystals was collected as above, yielding $15.1 \mathrm{~g}$ of product (11\%). The total yield of yellow crystalline $\mathbf{S 1}$ was $119.1 \mathrm{~g}(87 \%) .{ }^{1} \mathrm{H}$ NMR $\left(300 \mathrm{MHz}, \mathrm{CDCl}_{3}\right) \delta 9.97(\mathrm{~s}, 1 \mathrm{H}), 7.63(\mathrm{dd}, J=7.8,1.4 \mathrm{~Hz}, 1 \mathrm{H}), 7.55-$ 
$7.44(\mathrm{~m}, 1 \mathrm{H}), 7.17(\mathrm{td}, J=7.7,0.9 \mathrm{~Hz}, 1 \mathrm{H}), 6.86(\mathrm{~d}, J=8.3 \mathrm{~Hz}, 1 \mathrm{H}), 5.76(\mathrm{~s}, 1 \mathrm{H}), 3.82(\mathrm{~s}, 3 \mathrm{H})$, $3.78(\mathrm{~s}, 3 \mathrm{H}) .{ }^{13} \mathrm{C}$ NMR $\left(75 \mathrm{MHz}, \mathrm{CDCl}_{3}\right) \delta 169.2,163.8,145.3,143.5,133.3,133.1,123.8,120.7$, 116.5, 104.7, 98.8, 53.0, 51.7. HRMS calculated for $\mathrm{C}_{13} \mathrm{H}_{12} \mathrm{~N}_{2} \mathrm{O}_{4}: 261.0870(\mathrm{M}+\mathrm{H})^{+}$; Found: 261.0860 .

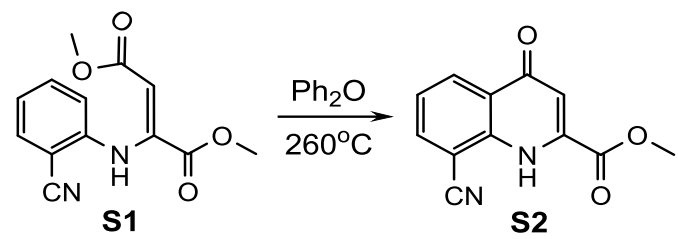

Methyl 8-cyano-4-oxo-1,4-dihydroquinoline-2-carboxylate (S2). (N. D. Heindel, T. A. Brodof, J. E. Kogelschatz, J. Heterocyclic Chem. 3, 222 (1966)) In a 2 L round-bottomed flask, 1L of diphenyl ether was heated to boiling $\left(260^{\circ} \mathrm{C}\right)$. Fumarate S1 $(50 \mathrm{~g}, 89 \mathrm{mmol})$ was added in portion wise over $1 \mathrm{~min}$ via a funnel. The mixture was further refluxed for about $12-15 \mathrm{~min}$. When the reaction was completed (based on TLC), the flask was left to cool down to $50{ }^{\circ} \mathrm{C}$. The mixture was then poured into $3 \mathrm{~L}$ of petroleum ether with shaking/stirring. The off-white solid that was formed was filtered and repeatedly washed with petroleum ether until TLC showed no more diphenyl ether to be present. After drying under reduced pressure, product $\mathbf{S 2}$ was obtained as an off-white solid (yield 75-85\%). ${ }^{1} \mathrm{H}$ NMR (300 MHz, $\left.\mathrm{CDCl}_{3}\right) \delta 9.28(\mathrm{~s}, 1 \mathrm{H}), 8.58(\mathrm{dd}, J=8.2,1.5 \mathrm{~Hz}, 1 \mathrm{H}), 8.02$ $(\mathrm{dd}, J=7.5,1.5 \mathrm{~Hz}, 1 \mathrm{H}), 7.47(\mathrm{dd}, J=8.4,7.8 \mathrm{~Hz}, 1 \mathrm{H}), 7.05(\mathrm{~s}, 1 \mathrm{H}), 4.10(\mathrm{~s}, 3 \mathrm{H}) .{ }^{13} \mathrm{C}$ NMR $(75$ $\left.\mathrm{MHz}, \mathrm{CDCl}_{3}\right) \delta 178.6,162.4,139.7,137.5,136.7,132.0,126.3,123.9,114.8,113.3,101.6,54.2$. HRMS calculated for $\mathrm{C}_{12} \mathrm{H}_{7} \mathrm{~N}_{2} \mathrm{O}_{3}: 227.0457(\mathrm{M}-\mathrm{H})^{-}$; Found: 227.0454.

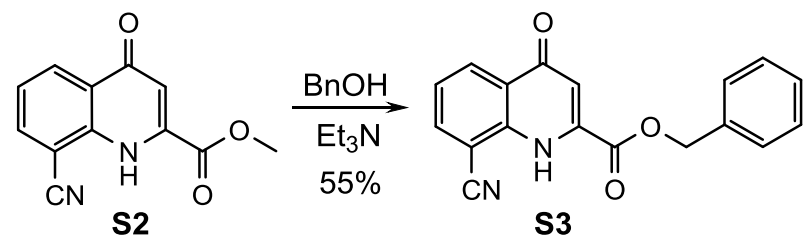

Benzyl 8-cyano-4-oxo-1,4-dihydroquinoline-2-carboxylate (S3). To compound S2 (10.39 g, $45.6 \mathrm{mmol})$ were added benzyl alcohol $(11.7 \mathrm{~mL}, 114 \mathrm{mmol}, 2.5$ equiv.) and triethylamine (12.6 $\mathrm{mL}, 114 \mathrm{mmol}, 2.0$ equiv.). The mixture was heated at $70{ }^{\circ} \mathrm{C}$ in an open flask overnight. When the reaction was complete, all volatiles were evaporated under reduced pressure. Co-evaporation was carried out twice with added $\mathrm{MeCN}$, and then twice with added $\mathrm{H}_{2} \mathrm{O}$. The resulting semi-solid residue was suspended in $200 \mathrm{~mL}$ of ice-cold water and stirred for $45 \mathrm{~min}$, then filtered and washed with ice-cold water. The solid was suspended in toluene and residual water was removed by coevaporation with toluene under reduce to afford the title compound as an off-white solid (yield $55 \%) .{ }^{1} \mathrm{H}$ NMR $\left(300 \mathrm{MHz}, \mathrm{CDCl}_{3}\right) \delta 9.30(\mathrm{~s}, 1 \mathrm{H}), 8.59(\mathrm{dd}, J=8.2,1.4 \mathrm{~Hz}, 1 \mathrm{H}), 8.02(\mathrm{dd}, J=7.5$, $1.5 \mathrm{~Hz}, 1 \mathrm{H}), 7.53-7.41(\mathrm{~m}, 5 \mathrm{H}), 7.10(\mathrm{~d}, J=1.3 \mathrm{~Hz}, 1 \mathrm{H}), 5.51(\mathrm{~s}, 2 \mathrm{H}) .{ }^{13} \mathrm{C}$ NMR $\left(75 \mathrm{MHz}, \mathrm{CDCl}_{3}\right)$ $\delta 178.3,161.9,139.6,137.5,136.8,134.0,132.0,129.2,128.9,128.6,126.3,123.9,114.8,113.3$, 101.6, 69.2. HRMS calculated for $\mathrm{C}_{18} \mathrm{H}_{11} \mathrm{~N}_{2} \mathrm{O}_{3}: 303.0775(\mathrm{M}-\mathrm{H})^{-}$; Found: 303.0771 .<smiles>Nc1cccc2c(=O)cc(C(=O)OCc3ccccc3)[nH]c12</smiles>

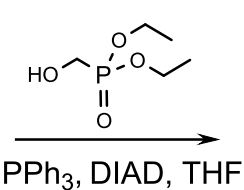

$\mathrm{PPh}_{3}, \mathrm{DIAD}, \mathrm{THF}$<smiles>CCOP(=O)(COc1cc(C(=O)OCc2ccccc2)nc2c(C#N)cccc12)OCC</smiles>

S4

Benzyl 8-cyano-4-((diethoxyphosphoryl)methoxy)quinoline-2-carboxylate (S4). Compound S3 $(12.47 \mathrm{~g}, 41 \mathrm{mmol})$ was placed in a flask equipped with a stirring bar, and dried under vacuum for $30 \mathrm{~min}$, then $\mathrm{PPh}_{3}$ (11.79 g, $45 \mathrm{mmol}, 1.1$ equiv.) was added followed by dry THF (100 mL) and 
diethyl (hydroxymethyl)phosphonate $(6.46 \mathrm{~mL}, 45 \mathrm{mmol}, 1.1$ equiv.). The mixture was stirred at $0{ }^{\circ} \mathrm{C}$ under nitrogen and DIAD ( $8.85 \mathrm{~mL}, 45 \mathrm{mmol}, 1.1$ equiv.) was added dropwise over $60 \mathrm{~min}$ at $0{ }^{\circ} \mathrm{C}$. The reaction was then continued for $120 \mathrm{~min}$ at room temperature, and then at $50{ }^{\circ} \mathrm{C}$ for $16 \mathrm{~h}$. The mixture was cooled to room temperature and THF was removed under reduced pressure yielding a brown viscous oil. DCM was added and the solution washed with water (x3) and brine (x2). The combined organic phases were dried over $\mathrm{Na}_{2} \mathrm{SO}_{4}$, filtered and solvents were evaporated under reduced pressure. Crystallization from $\mathrm{DCM} / \mathrm{Et}_{2} \mathrm{O}$ afforded the title compound as a white solid (11.96 g, 76\%). ${ }^{1} \mathrm{H}$ NMR $\left(300 \mathrm{MHz}, \mathrm{CDCl}_{3}\right) \delta 8.52(\mathrm{dd}, J=8.5,1.4 \mathrm{~Hz}, 1 \mathrm{H}), 8.22(\mathrm{dd}, J=$ 7.2, $1.4 \mathrm{~Hz}, 1 \mathrm{H}), 7.73(\mathrm{~s}, 1 \mathrm{H}), 7.70(\mathrm{dd}, J=8.2,6.9 \mathrm{~Hz}, 1 \mathrm{H}), 7.63-7.57(\mathrm{~m}, 2 \mathrm{H}), 7.47-7.33(\mathrm{~m}, 3 \mathrm{H})$, $5.55(\mathrm{~s}, 2 \mathrm{H}), 4.58(\mathrm{~d}, J=10.3 \mathrm{~Hz}, 2 \mathrm{H}), 4.30(\mathrm{dq}, J=8.4,7.1 \mathrm{~Hz}, 4 \mathrm{H}), 1.40(\mathrm{dt}, J=7.0,0.2 \mathrm{~Hz}, 5 \mathrm{H})$. ${ }^{13} \mathrm{C}$ NMR $\left(75 \mathrm{MHz}, \mathrm{CDCl}_{3}\right) \delta 164.8,162.6,162.5,151.2,147.8,136.9,135.4,128.7,128.4,128.2$, 127.0, 126.8, 122.1, 116.6, 114.1, 102.3, 67.9, 63.9, 63.3, 63.2, 61.6, 16.6, 16.5. ${ }^{31} \mathrm{P}$ NMR (122 $\left.\mathrm{MHz} \mathrm{CDCl}_{3}\right) \delta$ 17.00. HRMS calculated for $\mathrm{C}_{23} \mathrm{H}_{22} \mathrm{~N}_{2} \mathrm{O}_{6} \mathrm{P}: 453.1221(\mathrm{M}-\mathrm{H})^{-}$; Found: 453.1217.

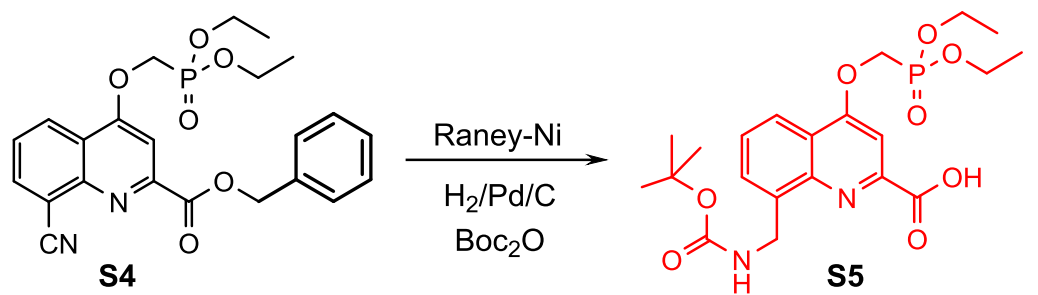

8-(((tert-Butoxycarbonyl)amino)methyl)-4-((diethoxyphosphoryl)methoxy) quinoline-2carboxylic acid (S5). Compound $\mathbf{S 4}(974 \mathrm{mg}, 2.14 \mathrm{mmol})$, Boc ${ }_{2} \mathrm{O}$ (1.5 equiv., $3.21 \mathrm{mmol}, 700 \mathrm{mg}$ ) and freshly distilled $\mathrm{Et}_{3} \mathrm{~N}(1.5$ equiv., $3.21 \mathrm{mmol}, 438 \mu \mathrm{L})$ were dissolved in $30 \mathrm{~mL}$ of a 1:1 mixture of THF and methanol. To this, commercial Raney nickel (approximately $1 \mathrm{~g}$ of wet solid) was added and the mixture was degassed under moderate vacuum. Then, a hydrogen balloon was connected to the flask and the mixture vigorously stirred at $50{ }^{\circ} \mathrm{C}$ for $20 \mathrm{~h}$. After cooling to room temperature, $\mathrm{Pd} / \mathrm{C}(10 \%)(100 \mathrm{mg})$ was added, the mixture was degassed by applying vacuum for $1 \mathrm{~min}$ and a new hydrogen balloon connected. The mixture was stirred at room temperature for 16 $\mathrm{h}$ under $\mathrm{H}_{2}$. Then it was diluted with $60 \mathrm{~mL}$ of DCM and passed through celite which was washed with DCM. Solvents were removed under reduced pressure and the resulting yellow oil was dissolved in DCM and washed with 5\% wt/vol aqueous citric acid (x2), followed by a 1:1 mixture of $5 \%$ aqueous citric acid and brine (x1), and finally with brine (x1). The organic phase was dried over $\mathrm{Na}_{2} \mathrm{SO}_{4}$, filtered and evaporated. The resulting oil was mixed with cyclohexane and heated to boiling until an emulsion was formed. It was allowed to cool down to room temperature which resulted in a phase separation. The cyclohexane layer was discarded. This operation was repeated. The crude product was purified by column chromatography using a gradient of $\mathrm{MeOH}(2-10 \%)$ in DCM and finally crystallised from DCM/Et ${ }_{2} \mathrm{O}$ yielding $\mathbf{S 5}$ as a white solid (yield $641 \mathrm{mg}, 64 \%$ ). ${ }^{1} \mathrm{H} \mathrm{NMR}\left(300 \mathrm{MHz}, \mathrm{CDCl}_{3}\right) \delta 8.29(\mathrm{dd}, J=8.4,1.4 \mathrm{~Hz}, 1 \mathrm{H}), 7.76(\mathrm{~s}, 1 \mathrm{H}), 7.73(\mathrm{br}-\mathrm{d}, J=7.2 \mathrm{~Hz}$, $1 \mathrm{H}), 7.62(\mathrm{dd}, J=7.7,8.3 \mathrm{~Hz}, 1 \mathrm{H}), 4.96(\mathrm{~s}, 2 \mathrm{H}), 4.60(\mathrm{~d}, J=10.3 \mathrm{~Hz}, 2 \mathrm{H}), 4.33(\mathrm{dq}, J=8.3,7.1$ $\mathrm{Hz}, 4 \mathrm{H}), 1.47(\mathrm{~s}, 9 \mathrm{H}), 1.43(\mathrm{t}, J=7.1 \mathrm{~Hz}, 6 \mathrm{H}) .{ }^{13} \mathrm{C} \mathrm{NMR}\left(75 \mathrm{MHz}, \mathrm{CDCl}_{3}\right) \delta 165.3,163.3,163.1$, 156.3, 146.9, 145.5, 137.5, 130.9, 127.8, 122.3, 121.9, 99.3, 79.8, 63.7, 63.3, 63.2, 61.5, 41.7, 28.5, 16.6, 16.5. ${ }^{31} \mathrm{P}$ NMR $\left(122 \mathrm{MHz}, \mathrm{CDCl}_{3}\right) \delta$ 17.50. HRMS calculated for $\mathrm{C}_{21} \mathrm{H}_{30} \mathrm{~N}_{2} \mathrm{O}_{8} \mathrm{P}: 469.1734$ $(\mathrm{M}+\mathrm{H})^{+}$; Found: 469.1720.<smiles>COC(=O)c1cc(=O)c2cccc([N+](=O)[O-])c2[nH]1</smiles> 
8-Nitro-4-oxo-1,4-dihydroquinoline-2-carboxylic acid (S7). Compound S6 (18) (11.15 g, 44.9 mmol) was suspended in a mixture of THF $(90 \mathrm{~mL})$ and methanol $(60 \mathrm{~mL})$. To this, was added $\mathrm{LiOH}_{\mathrm{H}} \mathrm{H}_{2} \mathrm{O}$ (4.72 g, $112 \mathrm{mmol}, 2.5$ equiv.) in $\mathrm{MeOH}(20 \mathrm{~mL})$ and the reaction mixture was vigorously stirred at $40{ }^{\circ} \mathrm{C}$ for $1 \mathrm{~h}$ (completion was confirmed by TLC). Solvents were removed under reduced pressure and the red/brown solid obtained was triturated with $2 \mathrm{M} \mathrm{HCl}$ with vigorous stirring to $\mathrm{pH} 1-2$. The solids were filtered and washed with sufficient amount of water. The residual water was removed by co-evaporation with toluene, then $\mathrm{Et}_{2} \mathrm{O}$. Acid $\mathbf{S 7}$ was obtained as a yellow solid (yield 97\%) and used in the next step without further purification. ${ }^{1} \mathrm{H}$ NMR $(300 \mathrm{MHz}$, DMSO-d $\left._{6}\right) \delta 11.63(\mathrm{~s}, 1 \mathrm{H}), 8.72-8.64(\mathrm{dd}, J=8.0,1.1 \mathrm{~Hz}, 1 \mathrm{H}), 8.55(\mathrm{dd}, J=8.0,1.5 \mathrm{~Hz}, 1 \mathrm{H}), 7.59$ $(\mathrm{t}, J=8.0 \mathrm{~Hz}, 1 \mathrm{H}), 6.82$ (s, 1H). ${ }^{13} \mathrm{C}$ NMR $\left(75 \mathrm{MHz}, \mathrm{DMSO}-\mathrm{d}_{6}\right) \delta 176.7,163.5,139.95,137.2$, 134.3, 133.9, 131.2, 127.5, 123.6, 111.5. HRMS calculated for $\mathrm{C}_{10} \mathrm{H}_{5} \mathrm{~N}_{2} \mathrm{O}_{5}: 233.0204(\mathrm{M}-\mathrm{H})^{-}$; Found: 233.0198.

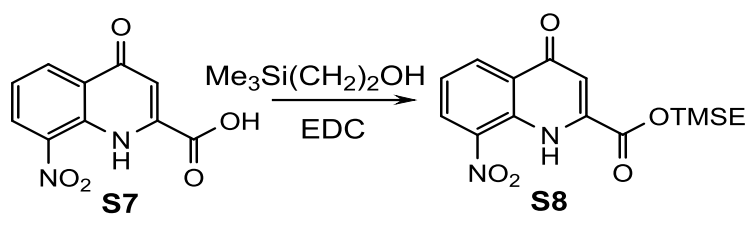

2-(Trimethylsilyl)ethyl 8-nitro-4-oxo-1,4-dihydroquinoline-2-carboxylate (S8). Acid S7 (9.3 g, $39.7 \mathrm{mmol}$ ) was suspended in $100 \mathrm{~mL}$ of dry DMF and 2-(trimethylsilyl)ethanol $(6.80 \mathrm{~mL}, 47.6$ mmol, 1.2 equiv.) was added in one portion with stirring. Then $\mathrm{EDC}(\mathrm{HCl}$ salt, $9.13 \mathrm{~g}, 47.6 \mathrm{mmol}$, 1.2 equiv.) was added. The reaction mixture was then stirred at room temperature under $\mathrm{N}_{2}$. Water $(300 \mathrm{~mL})$ was then added to the mixture with vigorous stirring and the reaction mixture was poured into $1000 \mathrm{~mL}$ of water and left stirring for $30 \mathrm{~min}$. Solids were filtered and washed repeatedly with cold water. The solid was suspended in toluene and residual water was removed by co-evaporation of toluene, then $\mathrm{Et}_{2} \mathrm{O}$. The crude solid was dissolved in boiling acetone and the hot solution was filtered. The filtrate was evaporated under reduced pressure to yield the title compound as a yellow solid (yield 90-92\%). ${ }^{1} \mathrm{H}$ NMR $\left(300 \mathrm{MHz}, \mathrm{CDCl}_{3}\right) \delta 11.81(\mathrm{~s}, 1 \mathrm{H}), 8.75(\mathrm{dd}, J=8.0,8.0 \mathrm{~Hz}, 1 \mathrm{H})$, $8.74(\mathrm{dd}, J=8.0,8.0 \mathrm{~Hz}, 1 \mathrm{H}), 7.50(\mathrm{t}, J=8.0 \mathrm{~Hz}, 1 \mathrm{H}), 7.08(\mathrm{~d}, J=1.7 \mathrm{~Hz}, 1 \mathrm{H}), 4.74-4.44(\mathrm{~m}, 2 \mathrm{H})$, 1.33-1.08 (m, 2H), 0.13 (s, 9H). ${ }^{13} \mathrm{C}$ NMR $\left(75 \mathrm{MHz}, \mathrm{CDCl}_{3}\right) \delta 177.8,161.7,137.8,135.8,135.0$, 134.1, 131.1, 128.1, 122.7, 113.0, 66.4, 17.4, -1.5. HRMS calculated for $\mathrm{C}_{15} \mathrm{H}_{17} \mathrm{~N}_{2} \mathrm{O}_{5} \mathrm{Si}: 333.0912$ $(\mathrm{M}+\mathrm{H})^{-}$; Found: 333.0912.

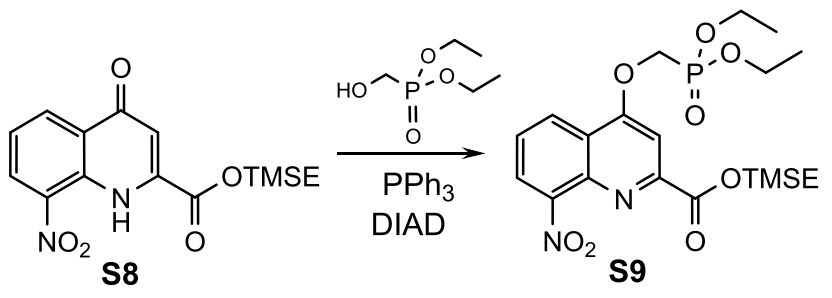

2-(Trimethylsilyl)ethyl 4-((diethoxyphosphoryl)methoxy)-8-nitroquinoline-2-carboxylate (S9) was obtained and purified according to the protocol used for $\mathbf{S 4}$ as a yellowish solid (yield 6075\%). ${ }^{1} \mathrm{H}$ NMR $\left(300 \mathrm{MHz}, \mathrm{CDCl}_{3}\right) \delta 7.59(\mathrm{~s}, 1 \mathrm{H}), 7.58(\mathrm{dd}, J=7.7,1.8 \mathrm{~Hz}, 1 \mathrm{H}), 7.45(\mathrm{dd}, J=7.6$, $7.6 \mathrm{~Hz}, 1 \mathrm{H}), 7.08(\mathrm{dd}, J=7.5,1.1 \mathrm{~Hz}, 1 \mathrm{H}), 4.62-4.53(\mathrm{~m}, 2 \mathrm{H}), 4.57(\mathrm{~d}, J=10.1 \mathrm{~Hz}, 2 \mathrm{H}),(4.33(\mathrm{dq}$, $J=8.1,7.1 \mathrm{~Hz}, 2 \mathrm{H}), 1.42(\mathrm{t}, J=7.1 \mathrm{~Hz}, 6 \mathrm{H}), 1.30-1.22(\mathrm{~m}, 2 \mathrm{H}), 0.16(\mathrm{~s}, 9 \mathrm{H}) .{ }^{13} \mathrm{C}$ NMR $(75 \mathrm{MHz}$, $\left.\mathrm{CDCl}_{3}\right) \delta 164.7,162.1,161.96,151.5,148.4,139.8,126.4,125.8,124.9,122.6,102.1,64.8,63.8$, 63.2, 63.1, 61.6, 17.1, 16.5, 16.4, -1.52. ${ }^{31} \mathrm{P} \mathrm{NMR}\left(122 \mathrm{MHz}, \mathrm{CDCl}_{3}\right) \delta 16.95$. HRMS calculated for $\mathrm{C}_{20} \mathrm{H}_{28} \mathrm{~N}_{2} \mathrm{O}_{8} \mathrm{PSi}$ : 483.1358 (M-H) ${ }^{-}$; Found: 483.1356. 


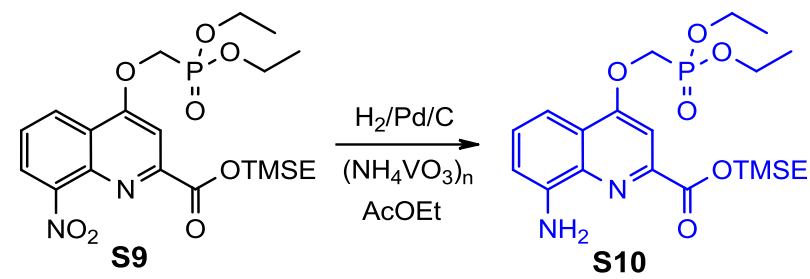

2-(trimethylsilyl)ethyl 8-amino-4-((diethoxyphosphoryl)methoxy) quinoline-2-carboxylate (S10). To compound S9 $(7.28 \mathrm{~g}, 15 \mathrm{mmol})$ and ammonium metavanadate $(0.1$ equiv., $730 \mathrm{mg})$ in a flask, EtOAc $(250 \mathrm{~mL})$ was added followed by $10 \% \mathrm{Pd} / \mathrm{C}(730 \mathrm{mg})$. The reaction mixture was vigorously stirred at room temperature for $16 \mathrm{~h}$ under $\mathrm{H}_{2}$. After filtration over celite, solvents were evaporated under reduced pressure, co-evaporated several times with $\mathrm{Et}_{2} \mathrm{O}$ and dried under vacuum. The title compound S10 obtained as a yellow solid was used for the next step without further purification (yield, 99\%). ${ }^{1} \mathrm{H}$ NMR $\left(300 \mathrm{MHz}, \mathrm{DMSO}-\mathrm{d}_{6}\right) \delta 7.65(\mathrm{~s}, 1 \mathrm{H}), 7.43(\mathrm{t}, J=7.9 \mathrm{~Hz}, 1 \mathrm{H})$, $7.24(\mathrm{dd}, J=8.2,1.2 \mathrm{~Hz}, 1 \mathrm{H}), 6.95(\mathrm{dd}, J=7.6,1.2 \mathrm{~Hz}, 1 \mathrm{H}), 6.08(\mathrm{~s}, 2 \mathrm{H}), 4.83(\mathrm{~d}, J=9.9 \mathrm{~Hz}, 2 \mathrm{H})$, 4.54-4.44 (m, 2H), 4.19 (dq, $J=14.1,7.0 \mathrm{~Hz}, 4 \mathrm{H}), 1.29(\mathrm{t}, J=7.0 \mathrm{~Hz}, 6 \mathrm{H}), 1.22-1.14(\mathrm{~m}, 2 \mathrm{H}), 0.13$ (s, 9H). ${ }^{13} \mathrm{C}$ NMR $\left(75 \mathrm{MHz}, \mathrm{CDCl}_{3}\right) \delta 165.7,162.1,161.9,146.1,145.1,138.4,129.09,122.5$, 111.0, 109.3, 100.7, 64.3, 63.4, 63.2, 63.1, 61.2, 17.4, 16.6, 16.5, -1.4. ${ }^{31} \mathrm{P} \mathrm{NMR}\left(122 \mathrm{MHz}, \mathrm{CDCl}_{3}\right)$ $\delta$ 17.74. HRMS calculated for $\mathrm{C}_{20} \mathrm{H}_{30} \mathrm{~N}_{2} \mathrm{O}_{6} \mathrm{PSi}: 453.1616(\mathrm{M}-\mathrm{H})^{-}$; Found: 453.1612.

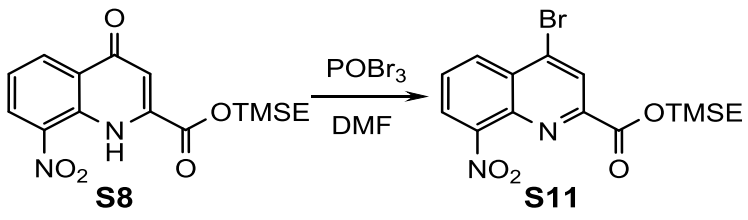

2-(Trimethylsilyl)ethyl 4-bromo-8-nitroquinoline-2-carboxylate (S11). To a dry $250 \mathrm{~mL}$ round bottom flask containing compound $\mathbf{S 8}(9.68 \mathrm{~g}, 29 \mathrm{mmol})$ and a magnetic stirrer under $\mathrm{N}_{2}$, anhydrous DMF (120 mL) was added followed by $\mathrm{POBr}_{3}(12.48 \mathrm{~g}, 1.5$ equiv.). The mixture was stirred at 70 ${ }^{\circ} \mathrm{C}$ for $4 \mathrm{~h}$ with TLC monitoring. After cooling to room temperature, the mixture was slowly poured into $1 \mathrm{~L}$ of stirred ice-cold water. Still under stirring, $5 \%$ wt/vol aqueous $\mathrm{NaHCO}_{3}$ was added until $\mathrm{pH} 8$ was reached. The mixture was allowed to stand for $15 \mathrm{~min}$, then EtOAc was added and the product was extracted in the organic layer. The aqueous phase was extracted once more with EtOAc and the combined organic phases were washed with water (x4), brine (x1), dried over $\mathrm{Na}_{2} \mathrm{SO}_{4}$, and filtered. Solvents were removed under reduced pressure and purification of the residue by silicagel chromatography eluting with cyclohexane:DCM 1:1 $\rightarrow 1: 2$ afforded compound S11 as a yellow/brownish solid (yield 91\%). ${ }^{1} \mathrm{H}$ NMR $\left(300 \mathrm{MHz}, \mathrm{CDCl}_{3}\right) \delta 8.62(\mathrm{~s}, 1 \mathrm{H}), 8.51$ (dd, $J=8.6$, $1.3 \mathrm{~Hz}, 1 \mathrm{H}), 8.17(\mathrm{dd}, J=7.5,1.3 \mathrm{~Hz}, 1 \mathrm{H}), 7.85(\mathrm{dd}, J=8.6,7.5 \mathrm{~Hz}, 2 \mathrm{H}), 4.63-4.55(\mathrm{~m}, 2 \mathrm{H})$, $1.29-1.21(\mathrm{~m}, 2 \mathrm{H}), 0.14(\mathrm{~s}, 9 \mathrm{H}) .{ }^{13} \mathrm{C}$ NMR $\left(75 \mathrm{MHz}, \mathrm{CDCl}_{3}\right) \delta 163.76,149.93,148.94,139.41$, $135.33,130.56,129.31,128.42,126.63,125.05,65.24,17.29,-1.42$. HRMS calculated for $\mathrm{C}_{15} \mathrm{H}_{17} \mathrm{BrN}_{2} \mathrm{O}_{4} \mathrm{NaSi}: 419.0033(\mathrm{M}+\mathrm{H})^{+}$; Found: 419.0028.

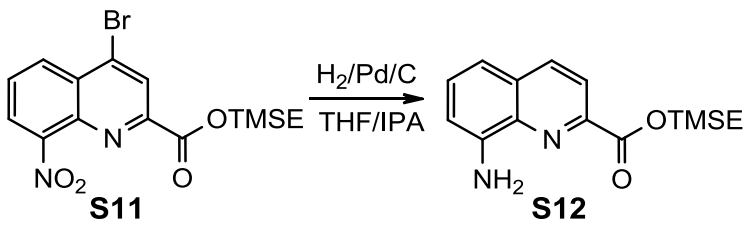

2-(Trimethylsilyl)ethyl 8-aminoquinoline-2-carboxylate (S12). Coumpound S11 (9.65 g, 24.3 mmol) was dissolved in a mixture of 2-propanol $(150 \mathrm{~mL})$ and THF $(50 \mathrm{~mL})$. To this, $10 \% \mathrm{Pd} / \mathrm{C}$ (960 mg) and $\mathrm{Na}_{2} \mathrm{CO}_{3}(2.58 \mathrm{~g}, 24.3 \mathrm{mmol}, 1$ equiv.) were added. The mixture was vigorously stirred at room temperature for $18 \mathrm{~h}$ under $\mathrm{H}_{2}$. The solution was filtered over celite, solvents were removed 
under reduced pressure and the resulting residue was dissolved in EtOAc. The solution was washed with water (x2) and the combined aqueous fractions were back extracted with EtOAc. The combined organic fractions were washed with brine (x2), dried over $\mathrm{Na}_{2} \mathrm{SO}_{4}$, filtered and evaporated under reduced pressure. The crude material was purified on a short silica column using DCM as eluent yielding pure $\mathbf{S 1 2}$ as a red oil that slowly solidifies (yield 70\%). The compound was used immediately for the next step without further purification. ${ }^{1} \mathrm{H} \mathrm{NMR}\left(300 \mathrm{MHz}, \mathrm{CDCl}_{3}\right) \delta$ $8.18(\mathrm{dd}, J=19.9,8.6 \mathrm{~Hz}, 2 \mathrm{H}), 7.46(\mathrm{t}, J=7.7 \mathrm{~Hz}, 1 \mathrm{H}), 7.21$ (dd, $J=8.2,1.1 \mathrm{~Hz}, 1 \mathrm{H}), 7.01$ (dd, $J$ $=7.6,1.2 \mathrm{~Hz}, 1 \mathrm{H}), 4.62-4.54(\mathrm{~m}, 2 \mathrm{H}), 1.30-1.21(\mathrm{~m}, 2 \mathrm{H}), 0.16(\mathrm{~s}, 9 \mathrm{H}) .{ }^{13} \mathrm{C} \mathrm{NMR}\left(75 \mathrm{MHz}, \mathrm{CDCl}_{3}\right)$ $\delta$ 165.71, 145.37, 145.04, 137.53, 136.80, 130.01, 129.84, 121.11, 115.04, 110.15, 64.08, 17.37, 1.33. HRMS calculated for $\mathrm{C}_{15} \mathrm{H}_{20} \mathrm{~N}_{2} \mathrm{NaO}_{2} \mathrm{Si}$ : $311.1186(\mathrm{M}+\mathrm{H})^{+}$; Found: 311.1184 .

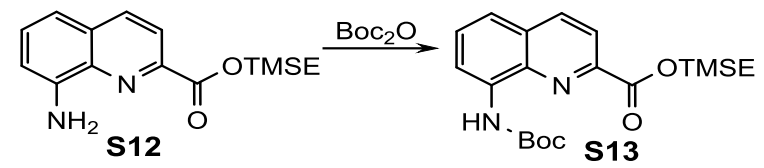

2-(Trimethylsilyl)ethyl 8-((tert-butoxycarbonyl)amino)quinoline-2-carboxylate (S13). Compound S12 (4.90 g, $17 \mathrm{mmol}$ ), Boc $2 \mathrm{O}$ (14.8 g, 68 mmol, 4 equiv.), DIPEA (4 $11.9 \mathrm{~mL}, 68$ mmol, 4 equiv.) were dissolved in $125 \mathrm{~mL}$ of 1,4-dioxane and the mixture was heated to reflux for $16 \mathrm{~h}$. Then additional $\mathrm{Boc}_{2} \mathrm{O}$ (7.4 g, 34 mmol, 2 equiv.) and DIPEA (6.0 mL, 34 mmol, 2 equiv.) were added and refluxing continued for 3 days until all the starting material was consumed (based on ${ }^{1} \mathrm{H}-\mathrm{NMR}$ spectra of aliquots). Solvents were then evaporated under reduced pressure and the residue was dissolved in DCM, washed with 5\% wt/vol aqueous citric acid (x3), brine (x2), dried over $\mathrm{Na}_{2} \mathrm{SO}_{4}$ and filtered. Solvents were removed under reduced pressure to afford the title compound as an orange oil which slowly solidified over a number of days (yield $96 \%$ ). ${ }^{1} \mathrm{H}$ NMR $\left(300 \mathrm{MHz}, \mathrm{CDCl}_{3}\right) \delta 9.07(\mathrm{~s}, 1 \mathrm{H}), 8.53(\mathrm{~d}, J=7.6 \mathrm{~Hz}, 1 \mathrm{H}), 8.31-8.19(\mathrm{~m}, 2 \mathrm{H}), 7.64(\mathrm{t}, J=8.0 \mathrm{~Hz}$, $1 \mathrm{H}), 7.50(\mathrm{dd}, J=8.3,1.2 \mathrm{~Hz}, 1 \mathrm{H}), 4.68-4.56(\mathrm{~m}, 2 \mathrm{H}), 1.63(\mathrm{~s}, 9 \mathrm{H}), 1.32-1.20(\mathrm{~m}, 2 \mathrm{H}), 0.18(\mathrm{~s}$, $9 \mathrm{H}) .{ }^{13} \mathrm{C}$ NMR $\left(75 \mathrm{MHz}, \mathrm{CDCl}_{3}\right) \delta 165.3,152.6,145.9,137.5,137.3,136.2,129.6,129.2,121.3$, 119.8, 115.1, 80.7, 64.3, 28.4, 17.2, -1.3. HRMS calculated for $\mathrm{C}_{20} \mathrm{H}_{28} \mathrm{~N}_{2} \mathrm{NaO}_{4} \mathrm{Si}: 411.1711$ $(\mathrm{M}+\mathrm{Na})^{+}$; Found: 411.1705 . 


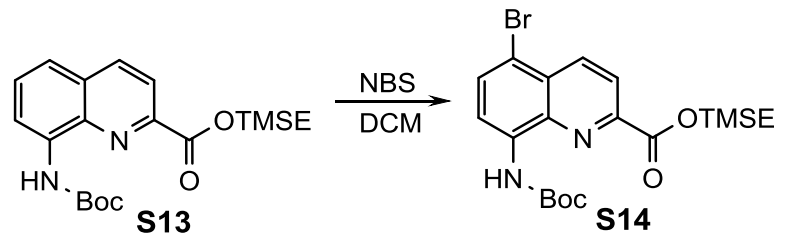

2-(Trimethylsilyl)ethyl 5-bromo-8-((tert-butoxycarbonyl)amino) quinoline-2-carboxylate (S14). To compound S13 (6.30 g, $16.2 \mathrm{mmol})$ in DCM (160 mL), N-bromosuccinimide $(4.32 \mathrm{~g}$, $24.3 \mathrm{mmol}, 1.5$ equiv.) was added in one portion and the mixture was left on stirring at room temperature. After $18 \mathrm{~h}$, completion of the reaction was confirmed by TLC. Solvents were evaporated under reduced pressure. DCM was added and evaporated under reduced pressure (x3). The resulting red/brown residue was then immediately purified on a short silica column with cyclohexane:DCM 2:1 $\rightarrow$ 1:1 followed by crystallization from hot n-hexane afforded $\mathbf{S 1 4}$ as a pale yellow solid (yield $6.13 \mathrm{~g}, 81 \%) .{ }^{1} \mathrm{H}$ NMR $\left(300 \mathrm{MHz}, \mathrm{CDCl}_{3}\right) \delta 9.05(\mathrm{~s}, 1 \mathrm{H}), 8.66(\mathrm{~d}, J=8.8 \mathrm{~Hz}$, $1 \mathrm{H}), 8.43(\mathrm{~d}, J=8.5 \mathrm{~Hz}, 1 \mathrm{H}), 8.29(\mathrm{~d}, J=8.7 \mathrm{~Hz}, 1 \mathrm{H}), 7.89(\mathrm{~d}, J=8.5 \mathrm{~Hz}, 1 \mathrm{H}), 4.68-4.57(\mathrm{~m}, 2 \mathrm{H})$, $1.62(\mathrm{~s}, 9 \mathrm{H}), 1.34-1.19(\mathrm{~m}, 2 \mathrm{H}), 0.18(\mathrm{~s}, 9 \mathrm{H}) .{ }^{13} \mathrm{C}$ NMR $\left(75 \mathrm{MHz}, \mathrm{CDCl}_{3}\right) \delta 164.7,152.5,146.4$, $138.0,137.0,136.1,132.9,128.2,122.3,115.5,112.3,81.0,64.5,28.4,17.2,-1.3$. HRMS calculated for $\mathrm{C}_{20} \mathrm{H}_{27} \mathrm{BrN}_{2} \mathrm{NaO}_{4} \mathrm{Si}$ : $489.0816(\mathrm{M}+\mathrm{Na})^{+}$; Found: 489.0806 .

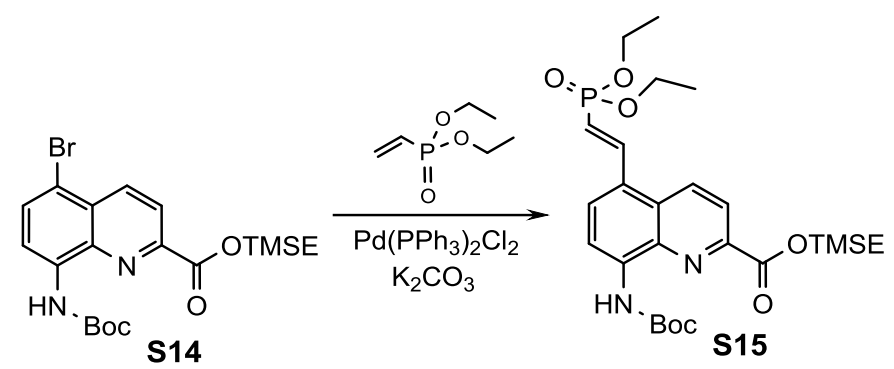

(E)-2-(Trimethylsilyl)ethyl8-((tert-butoxycarbonyl)amino)-5-(2(diethoxyphosphoryl)

vinyl)quinoline-2-carboxylate (S15). In a dry flask, compound $\mathbf{S 1 4}$ (1.08 g, $2.32 \mathrm{mmol}$,), diethyl vinylphosphonate $\left(440 \mu \mathrm{L}, 2.78 \mathrm{mmol}, 1.2\right.$ equiv.), dry $\mathrm{K}_{2} \mathrm{CO}_{3}(320 \mathrm{mg}, 2.32 \mathrm{mmol}, 1$ equiv.) and dry $o$-xylene $(10 \mathrm{~mL})$ were introduced under $\mathrm{N}_{2}$. To this, $\mathrm{Pd}\left(\mathrm{PPh}_{3}\right)_{2} \mathrm{Cl}_{2}(49 \mathrm{mg}, 0.07 \mathrm{mmol}, 0.03$ equiv.) was added under $\mathrm{N}_{2}$. The reaction was stirred at $125{ }^{\circ} \mathrm{C}$ and completion of reaction was confirmed after $16 \mathrm{~h}$ by ${ }^{1} \mathrm{H}$ NMR of an aliquot. The solution was cooled to room temperature, diluted with EtOAc and washed with 5\% wt/vol aqueous citric acid (x3) and brine (x1). The combined aqueous fractions were back-extracted with EtOAc. The combined organic phases were dried over $\mathrm{Na}_{2} \mathrm{SO}_{4}$ and filtered. Solvents were removed under reduced pressure and purification by silica gel chromatography eluting with cyclohexane: EtOAc $(2: 1 \rightarrow 3: 2 \rightarrow 1: 1)$ yielded $\mathbf{S 1 5}$ as a pale yellow solid (1.23 g, 97\%). ${ }^{1} \mathrm{H}$ NMR $\left(300 \mathrm{MHz}, \mathrm{CDCl}_{3}\right) \delta 9.22(\mathrm{~s}, 1 \mathrm{H}), 8.71(\mathrm{~d}, J=8.9 \mathrm{~Hz}, 1 \mathrm{H})$, $8.56(\mathrm{~d}, J=8.3 \mathrm{~Hz}, 1 \mathrm{H}), 8.27(\mathrm{~d}, J=6.4 \mathrm{~Hz}, 1 \mathrm{H}), 8.20(\mathrm{dd}, J=22.0,17.2 \mathrm{~Hz}, 1 \mathrm{H}), 7.95$ (d, $J=8.3$ $\mathrm{Hz}, 1 \mathrm{H}), 6.38(\mathrm{t}, J=8.7 \mathrm{~Hz}, 1 \mathrm{H}), 4.67-4.58(\mathrm{~m}, 2 \mathrm{H}), 4.28-4.15(\mathrm{~m}, 4 \mathrm{H}), 1.63(\mathrm{~s}, 9 \mathrm{H}), 1.42(\mathrm{t}, J=$ $7.1 \mathrm{~Hz}, 6 \mathrm{H}), 1.30-1.22(\mathrm{~m}, 2 \mathrm{H}), 0.18(\mathrm{~s}, 9 \mathrm{H}) .{ }^{13} \mathrm{C} \mathrm{NMR}\left(75 \mathrm{MHz}, \mathrm{CDCl}_{3}\right) \delta 164.9,152.5,146.0$, 143.3, 143.2, 138.1, 137.2, 133.2, 128.2, 127.3, 124.5, 124.2, 121.9, 117.0, 114.5, 114.5, 81.2, 64.5, 62.0, 61.9, 28.3, 17.2, 16.5, 16.4, -1.3. ${ }^{31} \mathrm{P}$ NMR $\left(122 \mathrm{MHz}, \mathrm{CDCl}_{3}\right) \delta 19.08$. HRMS calculated for $\mathrm{C}_{26} \mathrm{H}_{40} \mathrm{~N}_{2} \mathrm{O}_{7} \mathrm{PSi}$ : $551.2337(\mathrm{M}+\mathrm{H})^{+}$; Found: 551.2326. 


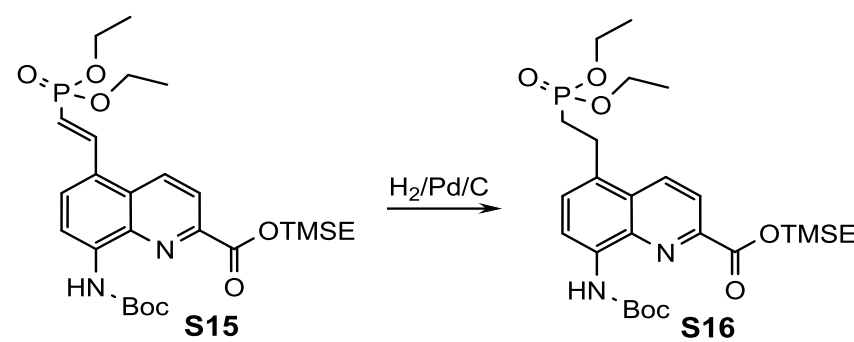

2-(Trimethylsilyl)ethyl 8-((tert-butoxycarbonyl)amino)-5-(2-(diethoxyphosphoryl) ethyl) quinoline-2-carboxylate (S16). Compound S15 (987 mg, $1.79 \mathrm{mmol}$ ) was dissolved in EtOAc (40 $\mathrm{mL})$ and $10 \% \mathrm{Pd} / \mathrm{C}(99 \mathrm{mg})$ was added as a slurry in a small amount of EtOAc. The reaction mixture was vigorously stirred at room temperature for $18 \mathrm{~h}$ under $\mathrm{H}_{2}$. The solution was filtered over celite and celite was washed with DCM. The solvents were removed under reduced pressure. Crude S16 ( quantitative) obtained was used in the next step without further purification. ${ }^{1} \mathrm{H}$ NMR $(300 \mathrm{MHz}$, $\left.\mathrm{CDCl}_{3}\right) \delta 9.07(\mathrm{~s}, 1 \mathrm{H}), 8.50(\mathrm{~d}, J=8.8 \mathrm{~Hz}, 1 \mathrm{H}), 8.43(\mathrm{~d}, J=8.0 \mathrm{~Hz}, 1 \mathrm{H}), 8.24(\mathrm{~d}, J=8.8 \mathrm{~Hz}, 1 \mathrm{H})$, $7.50(\mathrm{~d}, J=8.0 \mathrm{~Hz}, 1 \mathrm{H}), 4.66-4.58(\mathrm{~m}, 2 \mathrm{H}), 4.22-4.11(\mathrm{~m}, 4 \mathrm{H}), 3.40-3.28(\mathrm{~m}, 2 \mathrm{H}), 2.21-2.06(\mathrm{~m}$, 2H), $1.62(\mathrm{~s}, 9 \mathrm{H}), 1.37(\mathrm{t}, J=7.1 \mathrm{~Hz}, 6 \mathrm{H}), 1.30-1.22(\mathrm{~m}, 3 \mathrm{H}), 0.18(\mathrm{~s}, 9 \mathrm{H}) .{ }^{13} \mathrm{C}$ NMR $(75 \mathrm{MHz}$, $\left.\mathrm{CDCl}_{3}\right) \delta 165.2,152.8,145.6,138.0,135.6,133.3,129.4,129.2,128.9,127.4,121.3,114.8,80.7$, $64.4,61.8,61.7,28.4,28.0,26.2,24.7,24.7,17.2,16.5,16.5,-1.3 .{ }^{31} \mathrm{P} \mathrm{NMR}\left(122 \mathrm{MHz}, \mathrm{CDCl}_{3}\right) \delta$ 30.27. HRMS calculated for $\mathrm{C}_{26} \mathrm{H}_{42} \mathrm{~N}_{2} \mathrm{O}_{7} \mathrm{PSi}$ : $553.2493(\mathrm{M}+\mathrm{H})^{+}$; Found: 553.2483.
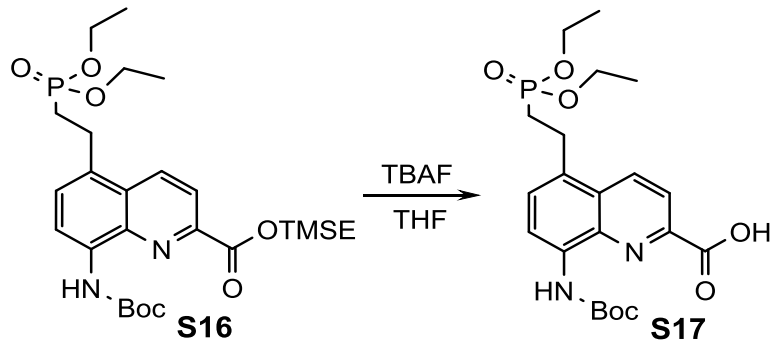

8-((tert-Butoxycarbonyl)amino)-5-(2-(diethoxyphosphoryl)ethyl) quinoline-2-carboxylic acid (S17). A solution of TBAF (1 M in THF, $5.60 \mathrm{~mL}, 5.56 \mathrm{mmol}, 1.5$ equiv.) in $40 \mathrm{~mL}$ of dry THF was added dropwise to a flask containing ester $\mathbf{S 1 6}(2.05 \mathrm{~g}, 3.71 \mathrm{mmol})$ in $60 \mathrm{~mL}$ of dry THF at $0^{\circ} \mathrm{C}$ under $\mathrm{N}_{2}$. The reaction mixture was left on stirring at room temperature for $6 \mathrm{~h}$. After completion of the reaction (based on TLC), the mixture was concentrated to approximately $5 \mathrm{~mL}$, diluted with chloroform and washed with $5 \% \mathrm{wt} / \mathrm{vol}$ aqueous citric acid (x3), then with brine $(\mathrm{x} 1)$. The combined aqueous fractions were back-extracted with chloroform. The combined organic phases were dried over $\mathrm{Na}_{2} \mathrm{SO}_{4}$ and filtered. After removal of solvents under reduced pressure, the title compound was obtained as a white solid $(1.59 \mathrm{~g}, 95 \%) .{ }^{1} \mathrm{H} \mathrm{NMR}\left(300 \mathrm{MHz}, \mathrm{CDCl}_{3}\right) \delta 10.94$ $(\mathrm{s}, 1 \mathrm{H}), 8.64(\mathrm{~d}, J=8.8 \mathrm{~Hz}, 1 \mathrm{H}), 8.49(\mathrm{~d}, J=7.9 \mathrm{~Hz}, 1 \mathrm{H}), 8.40(\mathrm{~d}, J=8.7 \mathrm{~Hz}, 1 \mathrm{H}), 7.57(\mathrm{~d}, J=8.1$ $\mathrm{Hz}, 1 \mathrm{H}), 4.26-4.10(\mathrm{~m}, 4 \mathrm{H}), 3.45-3.29(\mathrm{~m}, 2 \mathrm{H}), 2.24-2.06(\mathrm{~m}, 2 \mathrm{H}), 1.64(\mathrm{~s}, 9 \mathrm{H}), 1.38(\mathrm{t}, J=7.1 \mathrm{~Hz}$, $6 \mathrm{H}) .{ }^{13} \mathrm{C}$ NMR $\left(75 \mathrm{MHz}, \mathrm{CDCl}_{3}\right) \delta 166.1,153.3,144.9,137.7,134.9,134.0,129.8,129.6,129.2$, $127.9,120.9,115.9,81.4,62.2,62.1,28.4,27.9,26.0,24.7,24.7,16.5,16.4 .{ }^{31} \mathrm{P}$ NMR $(122 \mathrm{MHz}$, $\left.\mathrm{CDCl}_{3}\right) \delta 30.27$. HRMS calculated for $\mathrm{C}_{21} \mathrm{H}_{30} \mathrm{~N}_{2} \mathrm{O}_{7} \mathrm{P}: 453.1785(\mathrm{M}+\mathrm{H})^{+}$; Found: 453.1780. 


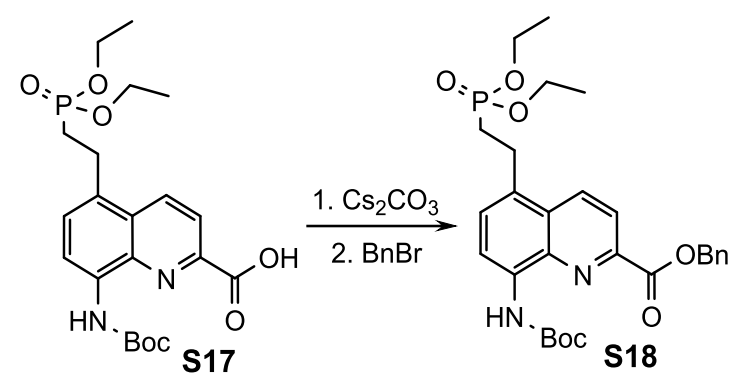

Benzyl 8-((tert-butoxycarbonyl)amino)-5-(2-(diethoxyphosphoryl) ethyl)quinoline-2carboxylate (S18). To a solution of acid $\mathbf{S 1 7}(1.53 \mathrm{~g}, 3.38 \mathrm{mmol})$ in methanol $(45 \mathrm{~mL})$ at $0^{\circ} \mathrm{C}$, $\mathrm{Cs}_{2} \mathrm{CO}_{3}\left(828 \mathrm{mg}, 2.54 \mathrm{mmol}, 0.75\right.$ equiv.) was added and the mixture was vigorously stirred at $0^{\circ} \mathrm{C}$ for $30 \mathrm{~min}$ and then at room temperature for $2.5 \mathrm{~h}$. The solvent was removed under reduced pressure and dried on the vacuum-line. Dry DMF $(30 \mathrm{~mL})$ was added, followed by benzyl bromide (4.06 mmol, 1.2 equiv.) and the reaction mixture was stirred overnight at room temperature. Volatiles were evaporated in vacuo and the residue was taken up in chloroform and washed with $5 \% \mathrm{wt} / \mathrm{vol}$ aqueous citric acid (x2) and brine (x1). The combined aqueous phases were back-extracted with chloroform. The combined organic phases were dried over $\mathrm{Na}_{2} \mathrm{SO}_{4}$, filtered and evaporated in vacuo. Recrystallization of the residue from $\mathrm{Et}_{2} \mathrm{O}$ yielded ester $\mathbf{S 1 8}$ as a white solid $(1.64 \mathrm{~g}, 90 \%)$. ${ }^{1} \mathrm{H} \mathrm{NMR}\left(300 \mathrm{MHz}, \mathrm{CDCl}_{3}\right) \delta 9.08(\mathrm{~s}, 1 \mathrm{H}), 8.50(\mathrm{~d}, J=8.8 \mathrm{~Hz}, 1 \mathrm{H}), 8.43(\mathrm{~d}, J=8.0 \mathrm{~Hz}, 1 \mathrm{H}), 8.26$ $(\mathrm{d}, J=8.8 \mathrm{~Hz}, 1 \mathrm{H}), 7.61-7.36(\mathrm{~m}, 5 \mathrm{H}), 5.54(\mathrm{~s}, 2 \mathrm{H}), 4.23-4.08(\mathrm{~m}, 4 \mathrm{H}), 3.40-3.26(\mathrm{~m}, 2 \mathrm{H}), 2.21-$ $2.05(\mathrm{~m}, 2 \mathrm{H}), 1.61(\mathrm{~s}, 9 \mathrm{H}), 1.36(\mathrm{t}, J=7.1 \mathrm{~Hz}, 6 \mathrm{H}) .{ }^{13} \mathrm{C} \mathrm{NMR}\left(75 \mathrm{MHz}, \mathrm{CDCl}_{3}\right) \delta 164.8,152.8$, 145.0, 138.0, 135.6, 135.1, 133.4, 129.4, 129.2, 129.1, 128.7, 128.4, 128.2, 127.5, 121.3, 114.8, 80.7, 67.5, 61.8, 61.7, 28.4, 28.0, 26.1, 24.7, 24.6, 16.5, 16.5. ${ }^{31} \mathrm{P}$ NMR $\left(122 \mathrm{MHz}, \mathrm{CDCl}_{3}\right) \delta 30.23$. HRMS calculated for $\mathrm{C}_{28} \mathrm{H}_{36} \mathrm{~N}_{2} \mathrm{O}_{7} \mathrm{P}: 543.2255(\mathrm{M}+\mathrm{H})^{+}$; Found: 543.2248.
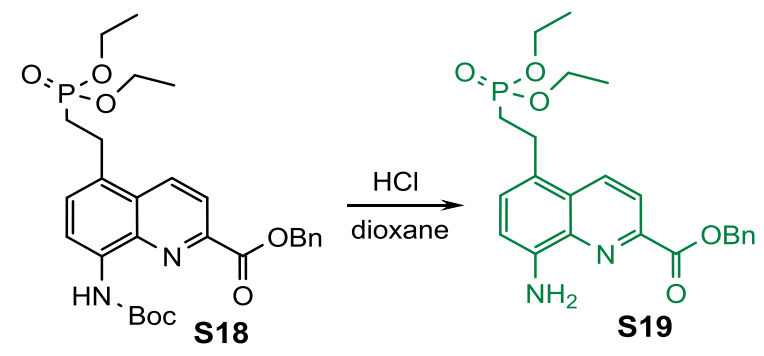

Benzyl 8-amino-5-(2-(diethoxyphosphoryl)ethyl)quinoline-2-carboxylate (S19). Compound $\mathbf{S 1 8}(1.82 \mathrm{~g}, 3.35 \mathrm{mmol})$ was dissolved in dry $\mathrm{CHCl}_{3}(17 \mathrm{~mL})$ and stirred at $0^{\circ} \mathrm{C}$ with an ice bath under $\mathrm{N}_{2}$. To this was added $4 \mathrm{M} \mathrm{HCl}$ in 1,4-dioxane (17 mL, $67 \mathrm{mmol}, 20$ equiv.) dropwise over $15 \mathrm{~min}$. Cooling was removed and stirring continued for $5 \mathrm{~h}$. When the reaction was completed based on TLC, excess HCL was removed by allowing air to bubble in the reaction mixture. The solution was diluted with $\mathrm{CHCl}_{3}$, washed with saturated sodium bicarbonate (x1) and brine (x1). The combined organic phases were dried over $\mathrm{Na}_{2} \mathrm{SO}_{4}$ and removal of solvent under reduced pressure afforded compound $\mathbf{S 1 9}$ as a dark orange viscous oil that was used immediately in the next step $(1.30 \mathrm{~g}, 88 \%) .{ }^{1} \mathrm{H}$ NMR $\left(300 \mathrm{MHz}, \mathrm{CDCl}_{3}\right) \delta 8.39(\mathrm{~d}, J=8.8 \mathrm{~Hz}, 1 \mathrm{H}), 8.20(\mathrm{~d}, J=8.8 \mathrm{~Hz}$, $1 \mathrm{H}), 7.58-7.35(\mathrm{~m}, 5 \mathrm{H}), 7.32(\mathrm{~d}, J=7.8 \mathrm{~Hz}, 1 \mathrm{H}), 6.91(\mathrm{~d}, J=7.7 \mathrm{~Hz}, 1 \mathrm{H}), 5.52(\mathrm{~s}, 2 \mathrm{H}), 4.22-4.07$ $(\mathrm{m}, 4 \mathrm{H}), 3.33-3.20(\mathrm{~m}, 2 \mathrm{H}), 2.17-2.02(\mathrm{~m}, 2 \mathrm{H}), 1.36(\mathrm{t}, J=7.1 \mathrm{~Hz}, 6 \mathrm{H}) .{ }^{13} \mathrm{C} \mathrm{NMR}\left(75 \mathrm{MHz}, \mathrm{CDCl}_{3}\right)$ $\delta 165.2,144.3,144.2,138.1,135.9,132.8,129.5,128.6,128.5,128.4,128.3,128.1,127.5,127.0$, $124.7,124.4,121.2,109.8,67.3,67.1,65.2,61.7,61.7,28.2,26.3,24.6,24.5,16.6,16.5 .{ }^{31} \mathrm{P} \mathrm{NMR}$ $\left(122 \mathrm{MHz}, \mathrm{CDCl}_{3}\right) \delta$ 30.64. HRMS calculated for $\mathrm{C}_{23} \mathrm{H}_{28} \mathrm{~N}_{2} \mathrm{O}_{5} \mathrm{P}: 443.1730(\mathrm{M}+\mathrm{H})^{+}$; Found: 443.1723 . 


\subsubsection{Synthesis of protected oligomers}

\section{Synthesis of the oligomers in the $\left({ }^{\mathrm{m}} \mathrm{QQ}\right)_{\mathrm{n}}$ series}
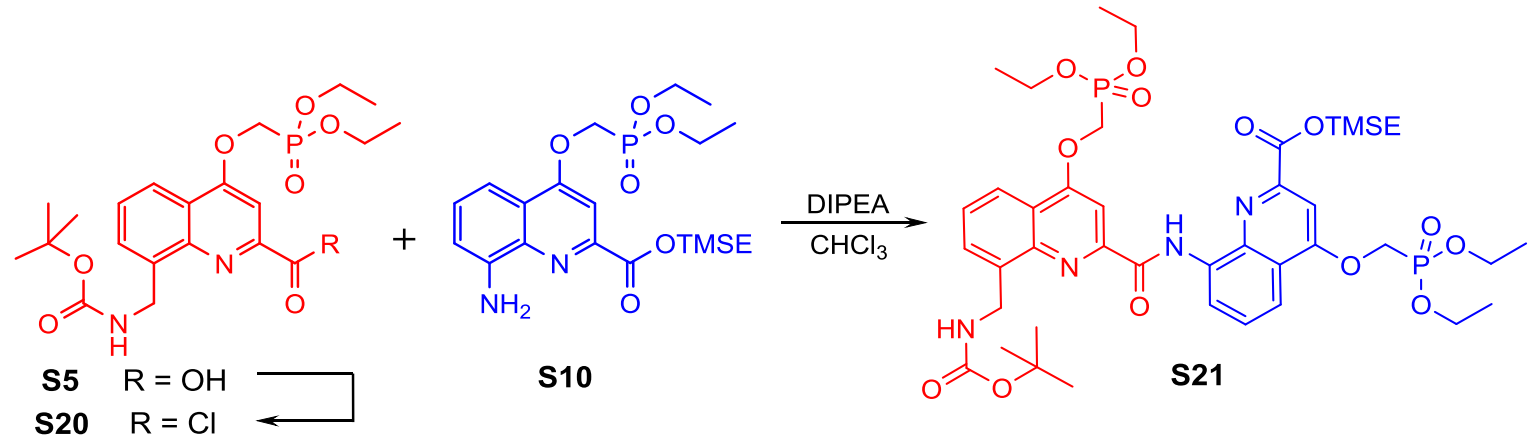

Compound S21. To a flask containing acid S5 (1.75 g, $3.74 \mathrm{mmol})$ under $\mathrm{N}_{2}$, dry $\mathrm{CHCl}_{3}(50 \mathrm{~mL})$ was added and the mixture stirred at $0{ }^{\circ} \mathrm{C}$ (ice bath) under $\mathrm{N}_{2}$. Ghosez's reagent $(990 \mu \mathrm{L}, 7.48$ mmol, 2 equiv.) was added dropwise to the solution over $20 \mathrm{~min}$. Cooling was removed and the mixture was stirred at room temperature for $2 \mathrm{~h}$. A ${ }^{1} \mathrm{H}$ NMR spectrum on an aliquot was recorded to confirm complete conversion. The solvents were removed under reduced pressure on the vacuum line and dried for $1.5 \mathrm{~h}$. Dry chloroform $(20 \mathrm{~mL})$ was added to the flask, and evaporated on the vacuum line and the residue was dried for $2 \mathrm{~h}$. In a separate dry flask, amine $\mathbf{S 1 0}(1.62 \mathrm{~g}, 3.55$ mmol, 0.95 equiv.) was dissolved $40 \mathrm{~mL}$ of dry $\mathrm{CHCl}_{3}$. Dry DIPEA (4.30mL, 26mmol, 7 equiv.) as added and the mixture was cooled to $0{ }^{\circ} \mathrm{C}$. The acid chloride $\mathbf{S 2 0}$ was dissolved in $20 \mathrm{~mL}$ of dry $\mathrm{CHCl}_{3}$ and added via syringe to the above amine solution over 40 min at $0{ }^{\circ} \mathrm{C}$ with stirring under $\mathrm{N}_{2}$. The reaction mixture was then stirred at room temperature for $18 \mathrm{~h}$ under $\mathrm{N}_{2}$. The mixture was diluted with DCM and washed with 5\% wt/vol aqueous citric acid (x3), water (x1), brine (x2). The combined aqueous phases were back-extracted with DCM. The combined organic phases were dried over $\mathrm{Na}_{2} \mathrm{SO}_{4}$, filtered and solvents were removed under reduced pressure. Recrystallization of the residue from $\mathrm{DCM} / \mathrm{Et}_{2} \mathrm{O}$ afforded the product $\mathbf{S 2 1}$ as greenish-white solid $(2.77 \mathrm{~g}, 87 \%) .{ }^{1} \mathrm{H}$ $\operatorname{NMR}\left(300 \mathrm{MHz}, \mathrm{CDCl}_{3}\right) \delta 12.41(\mathrm{~s}, 1 \mathrm{H}), 9.15(\mathrm{dd}, J=7.7,1.1 \mathrm{~Hz}, 1 \mathrm{H}), 8.26(\mathrm{dd}, J=8.4,1.1 \mathrm{~Hz}$, $1 \mathrm{H}), 8.02(\mathrm{dd}, J=8.4,1.1 \mathrm{~Hz}, 1 \mathrm{H}), 7.93(\mathrm{~d}, J=10.1 \mathrm{~Hz}, 2 \mathrm{H}), 7.91(\mathrm{~s}, 1 \mathrm{H}), 7.75(\mathrm{t}, J=8.1 \mathrm{~Hz}, 1 \mathrm{H})$, $7.67(\mathrm{~s}, 1 \mathrm{H}), 7.63(\mathrm{dd}, J=8.3,7.2 \mathrm{~Hz}, 1 \mathrm{H}), 5.76(\mathrm{t}, J=6.2 \mathrm{~Hz}, 1 \mathrm{H}), 5.25(\mathrm{~d}, J=6.2 \mathrm{~Hz}, 2 \mathrm{H}), 4.70-$ $4.58(\mathrm{~m}, 6 \mathrm{H}), 4.40-4.30(\mathrm{~m}, 8 \mathrm{H}), 1.45(\mathrm{t}, J=7.1,6 \mathrm{H}), 1.44(\mathrm{t}, J=7.1 \mathrm{~Hz}, 6 \mathrm{H}), 1.38(\mathrm{~s}, 9 \mathrm{H}), 1.30-$ $1.20(\mathrm{~m}, 2 \mathrm{H}), 0.16(\mathrm{~s}, 9 \mathrm{H}) .{ }^{13} \mathrm{C} \mathrm{NMR}\left(75 \mathrm{MHz}, \mathrm{CDCl}_{3}\right) \delta 164.5,163.1,162.9,162.9,162.4,162.21$, 156.4, 150.4, 147.9, 145.95, 139.7, 137.9, 135.2, 130.3, 128.7, 127.5, 121.9, 121.7, 120.94, 117.95, 115.8, 101.3, 98.2, 78.8, 64.5, 63.6, 63.57, 63.3, 63.2, 63.1, 61.32, 61.29, 41.9, 28.4, 17.6, 16.6, 16.5, -1.4. ${ }^{31} \mathrm{P}$ NMR $\left(122 \mathrm{MHz}, \mathrm{CDCl}_{3}\right) \delta 17.74,17.37$. HRMS calculated for $\mathrm{C}_{41} \mathrm{H}_{57} \mathrm{~N}_{4} \mathrm{O}_{13} \mathrm{P}_{2} \mathrm{Si}$ : 903.3172 (M-H) ${ }^{-}$; Found: 903.3179.

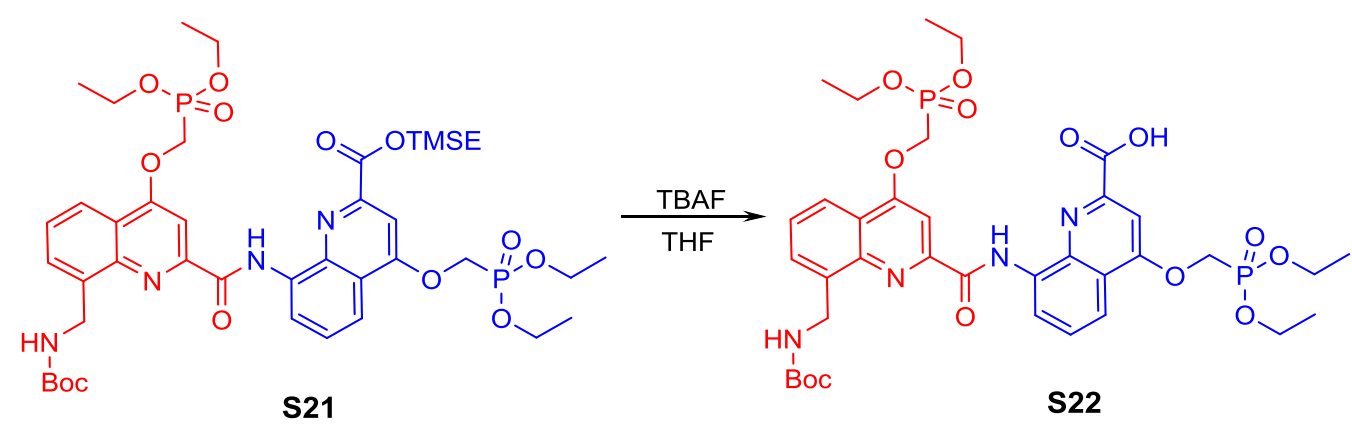

Dimer-acid S22. A solution of TBAF (1 M in THF, $6.45 \mathrm{~mL}, 6.45 \mathrm{mmol}, 1.5$ equiv.) in dry THF $(40 \mathrm{~mL})$ was added dropwise to a flask containing compound $\mathbf{S 2 1}(3.89 \mathrm{~g}, 4.30 \mathrm{mmol})$ in $60 \mathrm{~mL}$ of dry THF at $0{ }^{\circ} \mathrm{C}$ under $\mathrm{N}_{2}$. The reaction mixture was then stirred at room temperature for $5 \mathrm{~h}$. After 
completion of the reaction (based on TLC), $150 \mathrm{~mL}$ of $5 \% \mathrm{wt} / \mathrm{vol}$ aqueous citric acid was then slowly added to the reaction mixture with stirring. Then the slurry was poured into $500 \mathrm{~mL}$ of $5 \%$ wt/vol aqueous citric acid and stirred vigorously for $15 \mathrm{~min}$. Solids were filtered, thoroughly washed with water then with $\mathrm{Et}_{2} \mathrm{O}$, and dried under high-vacuum. Acid $\mathbf{S 2 2}$ was obtained as a white solid (3.34 g, 96\%) and did not require further purification. ${ }^{1} \mathrm{H} \mathrm{NMR}\left(300 \mathrm{MHz}, \mathrm{CDCl}_{3}\right) \delta 12.25$ (s, 1H), $9.14(\mathrm{~d}, J=6.9 \mathrm{~Hz}, 1 \mathrm{H}), 8.30(\mathrm{~d}, J=7.2 \mathrm{~Hz}, 1 \mathrm{H}), 8.06$ (dd, $J=8.4,1.1 \mathrm{~Hz}, 1 \mathrm{H}), 7.99$ (s, $1 \mathrm{H}), 7.82(\mathrm{~d}, J=6.3 \mathrm{~Hz}, 1 \mathrm{H}), 7.79-7.69(\mathrm{~m}, 2 \mathrm{H}), 7.64(\mathrm{dd}, J=8.3,7.2 \mathrm{~Hz}, 1 \mathrm{H}), 5.31(\mathrm{~s}, 2 \mathrm{H}), 5.06$ $(\mathrm{s}, 1 \mathrm{H}), 4.66(\mathrm{~d}, J=9.8 \mathrm{~Hz}, 2 \mathrm{H}), 4.63(\mathrm{~d}, J=9.9 \mathrm{~Hz}, 2 \mathrm{H}), 4.35(\mathrm{dq}, J=14.2,7.1 \mathrm{~Hz}, 9 \mathrm{H}), 1.44(\mathrm{t}$, $J=7.1 \mathrm{~Hz}, 12 \mathrm{H}), 1.39$ (s, 9H). ${ }^{13} \mathrm{C}$ NMR $\left(75 \mathrm{MHz}, \mathrm{DMSO}, \mathrm{NH}_{4} \mathrm{HCO}_{3}\right.$ added) $\delta 168.8,163.1$, $162.95,162.6,161.5,161.3,158.3,156.8,150.5,145.4,139.3,139.2,134.9,129.2,127.9,126.9$, 121.6, 120.7, 120.1, 116.4, 115.7, 102.7, 99.3, 78.0, 63.5, 63.2, 63.0, 63.0, 62.9, 62.9, 61.3, 61.0, 28.7, 16.9, 16.8. ${ }^{31} \mathrm{P}$ NMR (122 MHz, DMSO, $\mathrm{NH}_{4} \mathrm{HCO}_{3}$ added) $\delta 18.85,18.69$. HRMS calculated for $\mathrm{C}_{36} \mathrm{H}_{45} \mathrm{~N}_{4} \mathrm{O}_{13} \mathrm{P}_{2}$ : 803.2464 (M-H) ${ }^{-}$; Found: 803.2466.

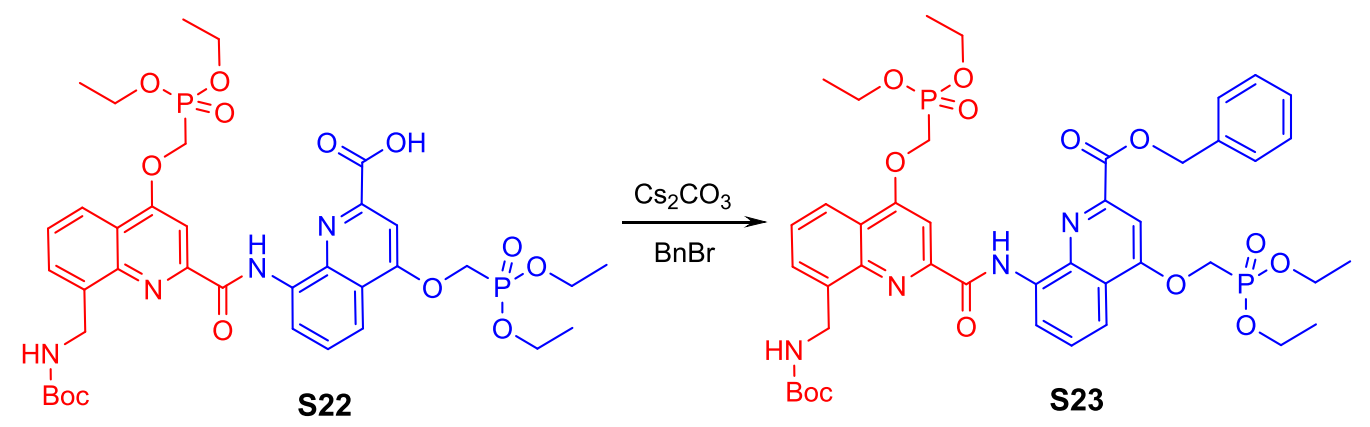

Compound S23. Compound S22 (1.695 g, $2.1 \mathrm{mmol})$ was dispersed in methanol $(30 \mathrm{~mL})$ and cooled to $0^{\circ} \mathrm{C}$. Then $\mathrm{Cs}_{2} \mathrm{CO}_{3}(515 \mathrm{mg}, 1.56 \mathrm{mmol}, 0.75$ equiv.) was added in one portion and the mixture was vigorously stirred at $0^{\circ} \mathrm{C}$ for $1 \mathrm{~h}$ and then at room temperature for $3 \mathrm{~h}$. The reaction mixture was evaporated in vacuo and dried on a vacuum line. To this, $20 \mathrm{~mL}$ of dry DMF was added followed by benzyl bromide $(299 \mu \mathrm{L}, 2.52 \mathrm{mmol}, 1.2$ equiv.). The reaction was stirred overnight at room temperature. Then volatiles were evaporated and the residue was dissolved in chloroform. The organic phase was washed with 5\% wt/vol aqueous citric acid (x2), brine (x1), and all aqueous phases were combined and back-extracted with chloroform. The combined organic phases were dried over $\mathrm{Na}_{2} \mathrm{SO}_{4}$, filtered over celite and concentrated in vacuo. The residue was dissolved in DCM/EtOAc and concentrated under reduced pressure which resulted in slow precipitation of the product. EtOAc was added and the mixture was placed at $-4{ }^{\circ} \mathrm{C}$ overnight. Crystals were collected by filtration, washed with cold $\mathrm{EtOAc}$, then $\mathrm{Et}_{2} \mathrm{O}$ and dried to yield pure dimer $\mathbf{S 2 3}$ as a white solid (1.793g, 95\%). ${ }^{1} \mathrm{H}$ NMR $\left(300 \mathrm{MHz}, \mathrm{CDCl}_{3}\right) \delta 12.42(\mathrm{~s}, 1 \mathrm{H}), 9.16(\mathrm{dd}$, $J=7.8,1.2 \mathrm{~Hz}, 1 \mathrm{H}), 8.25$ (dd, $J=8.4,1.1 \mathrm{~Hz}, 1 \mathrm{H}), 8.01$ (dd, $J=8.4,1.3 \mathrm{~Hz}, 1 \mathrm{H}), 7.92(\mathrm{~s}, 1 \mathrm{H})$, $7.90(\mathrm{~d}, J=7.6 \mathrm{~Hz}, 1 \mathrm{H}), 7.75(\mathrm{t}, J=8.1 \mathrm{~Hz}, 1 \mathrm{H}), 7.68-7.59(\mathrm{~m}, 2 \mathrm{H}), 7.56-7.51(\mathrm{~m}, 2 \mathrm{H}), 7.42-$ $7.33(\mathrm{~m}, 3 \mathrm{H}), 5.70(\mathrm{t}, J=6.6 \mathrm{~Hz}, 1 \mathrm{H}), 5.59(\mathrm{~s}, 2 \mathrm{H}), 5.24(\mathrm{~d}, J=6.2 \mathrm{~Hz}, 2 \mathrm{H}), 4.67(\mathrm{~d}, J=10.3 \mathrm{~Hz}$, $2 \mathrm{H}), 4.60(\mathrm{~d}, J=10.2 \mathrm{~Hz}, 2 \mathrm{H}), 4.42-4.26(\mathrm{~m}, 8 \mathrm{H}), 1.44(\mathrm{t}, J=14.6,7.2 \mathrm{~Hz}, 20 \mathrm{H}), 1.40(\mathrm{~s}, 6 \mathrm{H}) .{ }^{13} \mathrm{C}$ NMR $\left(75 \mathrm{MHz}, \mathrm{CDCl}_{3}\right) \delta 164.4,163.1,162.95,162.5,162.3,156.6,150.4,147.4,145.9,139.8$, 138.1, 135.6, 135.2, 130.1, 128.9, 128.7, 128.5, 128.4, 127.6, 121.9, 121.8, 120.9, 118.1, 115.8, 101.4, 98.2, 78.95, 67.7, 63.65, 63.3, 63.2, 63.1, 61.4, 41.6, 28.45, 16.62, 16.59, 16.55, 16.5. ${ }^{31} \mathrm{P}$ NMR $\left(122 \mathrm{MHz}, \mathrm{CDCl}_{3}\right) \delta 17.79,17.39$. HRMS calculated for $\mathrm{C}_{43} \mathrm{H}_{53} \mathrm{~N}_{4} \mathrm{O}_{13} \mathrm{P}_{2}: 895.3079(\mathrm{M}+\mathrm{H})^{+}$; Found: 895.3077. 


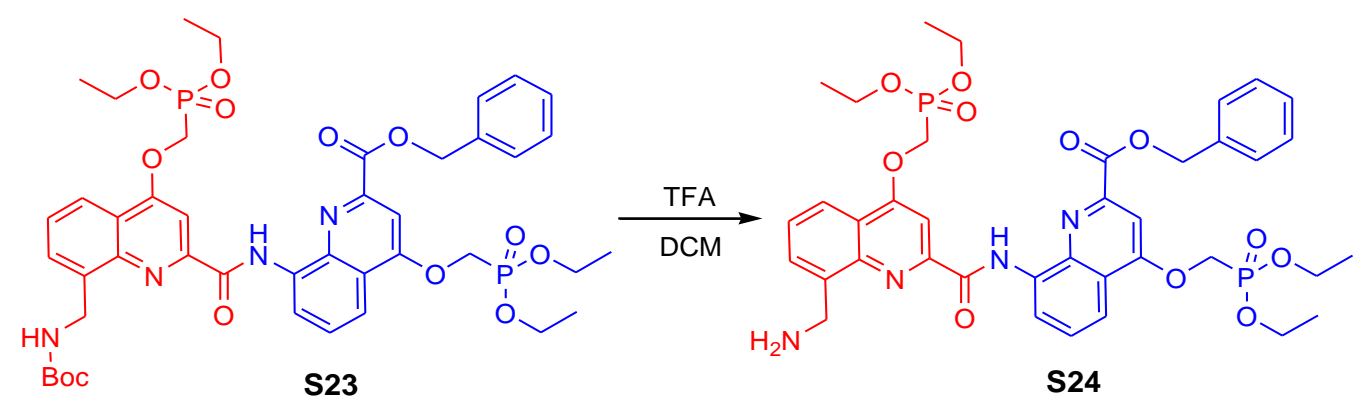

Dimer-amine S24. Compound S23 (1.95 g, $2.18 \mathrm{mmol})$ was dissolved in DCM (14 mL) and stirred at $0^{\circ} \mathrm{C}$. Then TFA $(3.45 \mathrm{~mL}, 43.6 \mathrm{mmol}, 20$ equiv.) was added to the mixture dropwise over $20 \mathrm{~min}$. The ice bath was removed and the reaction was stirred for $4 \mathrm{~h}$ at room temperature. Completion of the reaction was confirmed by TLC. The solvent and excess reagent were removed under reduced pressure, then co-evaporated with DCM (x2) and then $\mathrm{Et}_{2} \mathrm{O}(\mathrm{x} 2)$. The resulting light yellow solid was taken up in $\mathrm{CHCl}_{3}$ and washed with saturated aqueous $\mathrm{NaHCO}_{3}$ (x2), brine (x1). Aqueous phases were combined and back extracted with $\mathrm{CHCl}_{3}$. The combined organic phases were dried over $\mathrm{Na}_{2} \mathrm{SO}_{4}$, filtered and evaporated under reduced pressure to yield amine $\mathbf{S 2 4}$ as a yellow solid that was used without further purification $(1.632 \mathrm{~g}, 94 \%) .{ }^{1} \mathrm{H}$ NMR (TFA salt, $\left.300 \mathrm{MHz}, \mathrm{DMSO}\right)$ $\delta 12.39(\mathrm{~s}, 1 \mathrm{H}), 9.04(\mathrm{dd}, J=7.4,1.5 \mathrm{~Hz}, 1 \mathrm{H}), 8.29$ (dd, $J=8.4,1.1 \mathrm{~Hz}, 1 \mathrm{H}), 8.18$ (brs, 2H), 8.09$8.04(\mathrm{~m}, 2 \mathrm{H}), 7.99-7.82(\mathrm{~m}, 4 \mathrm{H}), 7.61-7.55(\mathrm{~m}, 2 \mathrm{H}), 7.42-7.30(\mathrm{~m}, 3 \mathrm{H}), 5.63(\mathrm{~s}, 2 \mathrm{H}), 5.10$ - 4.96 $(\mathrm{m}, 6 \mathrm{H}), 4.30-4.15(\mathrm{~m}, 8 \mathrm{H}), 1.32(\mathrm{t}, J=7.1 \mathrm{~Hz}, 6 \mathrm{H}), 1.32(\mathrm{t}, J=7.1 \mathrm{~Hz}, 6 \mathrm{H}) .{ }^{13} \mathrm{C}$ NMR (TFA salt, $75 \mathrm{MHz}$, DMSO-d $\left.{ }_{6}\right) \delta 164.4,163.5,163.4,162.8,162.6,162.2,159.6,159.1,158.6,158.1,151.1$, $147.6,145.3,139.2,136.2,135.1,132.56,132.49,129.46,128.99,128.7,128.5,128.1,122.8$, $121.9,121.8,117.9,117.3,115.9,114.1,110.2,103.2,100.1,67.8,63.8,63.0,63.0,62.95,62.9$, 61.6, 16.9, 16.85, 16.8, 16.77. ${ }^{31} \mathrm{P}$ NMR (TFA salt, $122 \mathrm{MHz}$, DMSO) $\delta 18.49,18.46$. HRMS calculated for $\mathrm{C}_{38} \mathrm{H}_{45} \mathrm{~N}_{4} \mathrm{O}_{11} \mathrm{P}_{2}$ : $795.2555(\mathrm{M}+\mathrm{H})^{+}$; Found: 795.2533.

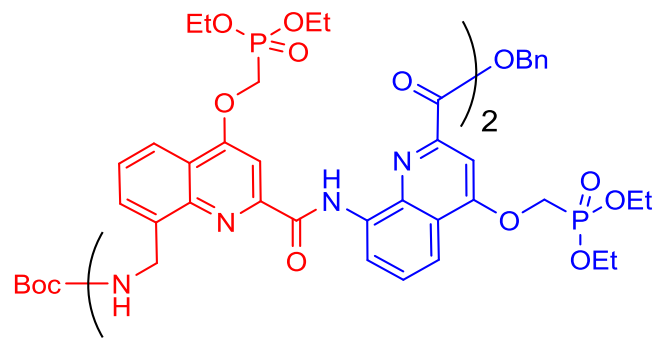

Tetramer S25. To a solution of acid $\mathbf{S 2 2}(1.70 \mathrm{~g}, 2.11 \mathrm{mmol})$ in dry $\mathrm{CHCl}_{3}(30 \mathrm{~mL})$, DIPEA (2.57 $\mathrm{mL}, 14.8 \mathrm{mmol}, 7$ equiv.) was added and the solution was stirred at $0{ }^{\circ} \mathrm{C}$ under $\mathrm{N}_{2}$. HBTU $(1.60 \mathrm{~g}$, $4.22 \mathrm{mmol}, 2$ equiv.) was added to the mixture and stirring was continued at $0{ }^{\circ} \mathrm{C}$ for $15 \mathrm{~min}$. A solution of amine $\mathbf{S 2 4}$ (1.60 g, $2.01 \mathrm{mmol}, 0.95$ equiv.) in $10 \mathrm{~mL}$ dry $\mathrm{CHCl}_{3}$ was added dropwise over $20 \mathrm{~min}$ and the mixture was then stirred for $18 \mathrm{~h}$ at room temperature under $\mathrm{N}_{2}$. The mixture was then diluted with $\mathrm{CHCl}_{3}$, washed with $5 \% \mathrm{wt} /$ vol aqueous citric acid (x3), saturated aqueous $\mathrm{NaHCO}_{3}\left(\mathrm{x} 1\right.$ ), and brine (x1). Aqueous phases were combined and back-extracted with $\mathrm{CHCl}_{3}$. The combined organic phases were dried over $\mathrm{Na}_{2} \mathrm{SO}_{4}$, filtered and evaporated in vacuo. The resulting oily residue was dissolved in DCM/ EtOAc. DCM was evaporated under slightly reduced pressure. Addition of small amounts of $\mathrm{Et}_{2} \mathrm{O}$ followed by excess EtOAc resulted in precipitation of byproducts and excess reagents which were removed by filtration through celite. The filtrate was evaporated to dryness and the residue was recrystallised from $\mathrm{DCM} / \mathrm{Et}_{2} \mathrm{O}$ and purified on silicagel chromatography (DCM: 5\% MeOH in EtOAc 10:85 $\rightarrow$ 20:75 $\rightarrow$ 30:65). Tetramer S25 was obtained as a pale yellow solid $(2.86 \mathrm{~g}, 90 \%) .{ }^{1} \mathrm{H}$ NMR $\left(300 \mathrm{MHz}, \mathrm{CDCl}_{3}\right) \delta 11.67(\mathrm{~s}, 1 \mathrm{H}), 11.56(\mathrm{~s}, 1 \mathrm{H})$, $10.00(\mathrm{t}, J=5.6 \mathrm{~Hz}, 1 \mathrm{H}), 8.95-8.86(\mathrm{~m}, 1 \mathrm{H}), 8.31(\mathrm{dd}, J=7.7,1.0 \mathrm{~Hz}, 1 \mathrm{H}), 8.18(\mathrm{~d}, J=8.1 \mathrm{~Hz}$, $1 \mathrm{H}), 8.06(\mathrm{~d}, J=8.2 \mathrm{~Hz}, 1 \mathrm{H}), 7.97(\mathrm{~d}, J=6.7 \mathrm{~Hz}, 1 \mathrm{H}), 7.86(\mathrm{~s}, 1 \mathrm{H}), 7.75-7.42(\mathrm{~m}, 8 \mathrm{H}), 7.38-7.23$ 
(m, 4H), $7.13(\mathrm{~s}, 1 \mathrm{H}), 6.97(\mathrm{~d}, J=6.9 \mathrm{~Hz}, 1 \mathrm{H}), 6.82(\mathrm{~s}, 1 \mathrm{H}), 5.56(\mathrm{~s}, 2 \mathrm{H}), 5.32(\mathrm{~d}, J=5.6 \mathrm{~Hz}, 2 \mathrm{H})$, $4.84(\mathrm{~d}, J=10.2 \mathrm{~Hz}, 2 \mathrm{H}), 4.58(\mathrm{~d}, J=10.6 \mathrm{~Hz}, 2 \mathrm{H}), 4.52-4.15(\mathrm{~m}, 21 \mathrm{H}), 3.89(\mathrm{~d}, J=6.2 \mathrm{~Hz}, 2 \mathrm{H})$, 1.55-1.46 (m, 24H), 1.26 (s, 9H). ${ }^{13} \mathrm{C}$ NMR $\left(75 \mathrm{MHz}, \mathrm{CDCl}_{3}\right) \delta 165.6,164.3,162.7,162.5,162.3$, $161.9,161.7,161.3,155.5,150.9,150.7,150.35,146.6,145.7,144.6,138.3,137.9,136.4,135.6$, 134.6, 134.2, 133.2, 131.1, 128.98, 128.8, 128.6, 128.4, 127.7, 127.2, 122.4, 122.0, 121.5, 120.5, $120.1,119.9,118.0,117.5,116.1,114.4,100.2$, 99.8, 99.1, 97.6, 79.1, 68.0, 63.9, 63.5, 63.3, 63.2, 63.2, 63.1, 61.7, 61.2, 61.0, 60.7, 44.4, 40.4, 28.2, 16.7, 16.6. ${ }^{31} \mathrm{P} \mathrm{NMR}\left(122 \mathrm{MHz}, \mathrm{CDCl}_{3}\right) \delta 18.19$, 18.15, 18.09, 17.94. HRMS calculated for $\mathrm{C}_{74} \mathrm{H}_{89} \mathrm{~N}_{8} \mathrm{O}_{23} \mathrm{P}_{4}$ : $1581.4985(\mathrm{M}+\mathrm{H})^{+}$; Found: 1581.4950.

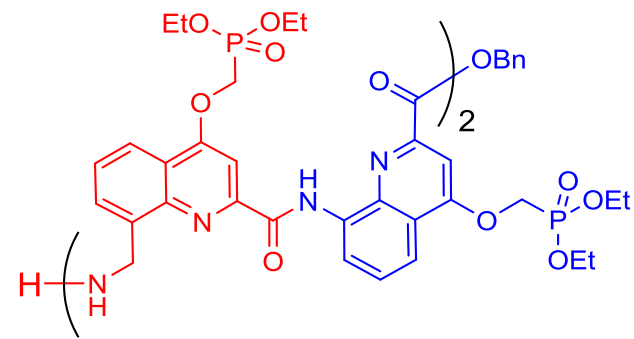

Tetramer-amine S26. Following the protocol described for the synthesis of amine S24. Amounts used: tetramer S25 (1.39 g, $0.88 \mathrm{mmol})$, TFA (1.4 mL, $17.6 \mathrm{mmol}, 20$ equiv.), DCM (5 mL). Crystallization from $\mathrm{DCM} / \mathrm{Et}_{2} \mathrm{O}$ afforded tetramer-amine $\mathbf{S 2 6}$ as a pale yellow solid (1.24 $\left.\mathrm{g}, 95 \%\right)$. HRMS calculated for $\mathrm{C}_{69} \mathrm{H}_{81} \mathrm{~N}_{8} \mathrm{O}_{21} \mathrm{P}_{4}$ : $1481.4461(\mathrm{M}+\mathrm{H})^{+}$; Found: 1481.4441.

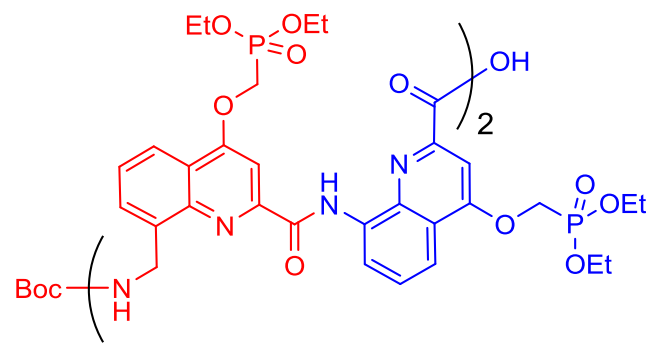

Tetramer-acid S27. Tetramer S25 (1.39 g, $0.88 \mathrm{mmol})$ was dissolved in a mixture of THF (25 $\mathrm{mL})$ and isopropanol $(25 \mathrm{~mL})$ and $10 \% \mathrm{Pd} / \mathrm{C}(139 \mathrm{mg})$ was added as a slurry in a small amount of isopropanol. The reaction mixture was vigorously stirred under $\mathrm{H}_{2}$ at room temperature for $18 \mathrm{~h}$, then filtered through celite and concentrated in vacuo. Recrystallization of the residue from $\mathrm{DCM} / \mathrm{Et}_{2} \mathrm{O}$ afforded tetramer-acid $\mathbf{S 2 7}$ as a pale yellow solid $(1.24 \mathrm{~g}, 95 \%)$ that was used without further purification. HRMS calculated for $\mathrm{C}_{67} \mathrm{H}_{81} \mathrm{~N}_{8} \mathrm{O}_{23} \mathrm{P}_{4}$ : $1489.4370(\mathrm{M}-\mathrm{H})^{-}$; Found: 1489.4352.<smiles>CCOP(=O)(COc1cc(C(=O)Nc2cccc3c(OCP(=O)(OCC)OCC)cc(C(=O)C(C)(C)Cc4ccccc4)nc23)nc2c(CNC(C)(C)C(C)(C)C)cccc12)OCC</smiles>

Octamer S28. Following the protocol described for the synthesis of tetramer S25. Amounts used: tetramer-acid S27 (1.16 g, $0.78 \mathrm{mmol}$ ), tetramer-amine $\mathbf{S 2 6}$ (1.15 g, $0.77 \mathrm{mmol}, 0.99$ equiv.), HBTU (599 mg, $1.58 \mathrm{mmol}, 2$ equiv.), DIPEA ( $964 \mu \mathrm{L}, 5.53 \mathrm{mmol}, 7$ equiv.), $\mathrm{CHCl}_{3}$ (15 mL for acid solution, $5 \mathrm{~mL}$ for amine solution, $10 \mathrm{~mL}$ for washing). In addition to the original protocol, reaction mixture was filtered through celite prior to aqueous workup. Octamer $\mathbf{S 2 8}$ was obtained by crystallization as a pale yellow solid $(1.97 \mathrm{~g}, 86 \%) .{ }^{1} \mathrm{H} \mathrm{NMR}\left(300 \mathrm{MHz}, \mathrm{CDCl}_{3}\right) \delta 11.36(\mathrm{~s}, 1 \mathrm{H})$, 
$11.13(\mathrm{~s}, 1 \mathrm{H}), 10.45(\mathrm{~s}, 1 \mathrm{H}), 10.29(\mathrm{~s}, 1 \mathrm{H}), 9.37-9.23(\mathrm{~m}, 2 \mathrm{H}), 8.91$ (brs, $1 \mathrm{H}), 8.52$ (dd, $J=7.4,1.5$ $\mathrm{Hz}, 1 \mathrm{H}), 8.09-7.90(\mathrm{~m}, 6 \mathrm{H}), 7.86-7.60(\mathrm{~m}, 5 \mathrm{H}), 7.52(\mathrm{t}, J=7.7,1 \mathrm{H}), 7.44-7.37(\mathrm{~m}, 3 \mathrm{H}), 7.37-7.14$ $(\mathrm{m}, 8 \mathrm{H}), 7.08(\mathrm{~d}, J=6.6 \mathrm{~Hz}, 1 \mathrm{H}), 6.98(\mathrm{~s}, 1 \mathrm{H}), 6.94-6.74(\mathrm{~m}, 7 \mathrm{H}), 6.69-6.47(\mathrm{~m}, 4 \mathrm{H}), 5.51$ (brs, 1H), 5.28 (brs, $1 \mathrm{H}), 5.19$ (brs, $1 \mathrm{H}), 5.03-3.76(\mathrm{~m}, 51 \mathrm{H}), 3.64$ (brs, $1 \mathrm{H}), 3.14$ (brs, $1 \mathrm{H}), 2.68$ (brs, 1H), 2.45 (brs, 1H), 1.71-1.36 (m, 48H), 1.11 (s, 9H). ${ }^{13} \mathrm{C}$ NMR (75 MHz, J-Mod, $\left.\mathrm{CDCl}_{3}\right) \delta 165.2$, 164.5, 164.4, 163.8, 162.6, 162.4, 162.4, 162.22, 162.2, 161.93, 161.9, 161.6, 161.6, 161.5, 161.5, $161.3,161.26,161.2,161.12,160.96,160.89,160.7,160.3,160.1,155.2,150.7,150.6,150.4$, $150.36,149.5,149.4,146.9,145.9,145.3,145.25,144.3,137.7,137.41,136.1,135.5,135.0,133.9$, $133.9,133.1,132.6,131.8,131.6,131.5,130.4,128.6,128.4,128.3,128.0,127.97,127.9,127.4$, 127.3, 126.8, 121.8, 121.7, 121.3, 121.2, 121.19, 121.0, 120.5, 120.0, 119.7, 119.6, 118.2, 118.0, 117.5, 117.3, 117.0, 116.0, 114.5, 114.4, 114.2, 99.9, 98.9, 98.3, 97.96, 97.8, 97.4, 97.1, 78.8, 67. 8, 63.8, 63.1, 63.1, 63.0, 62.9, 61.5, 61.0, 60.8, 60.7, 44.2, 43.3, 40.1, 28.3, 16.9, 16.83, 16.80, 16.76, 16.7, 16.6, 16.5. ${ }^{31} \mathrm{P}$ NMR (122 MHz, $\left.\mathrm{CDCl}_{3}\right) \delta 19.38,18.93,18.87,18.11$ (2P), 17.97, 17.75, 17.49. HRMS calculated for $\mathrm{C}_{136} \mathrm{H}_{162} \mathrm{~N}_{16} \mathrm{O}_{43} \mathrm{P}_{8}$ : $1477.44(\mathrm{M}+2 \mathrm{H})^{2+}$; Found: 1477.43. Analytical HPLC profile: see section 3.8.7.

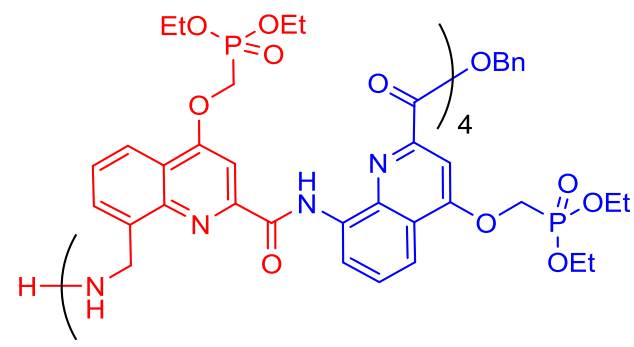

Octamer-amine S29. Following the protocol described for the synthesis of amine S24. Amounts used: octamer S28 (600 mg, $0.203 \mathrm{mmol})$, TFA (626 $\mu \mathrm{L}, 8.12 \mathrm{mmol}, 40$ equiv.), DCM (2.5 mL). Crystallization from DCM/Et $2 \mathrm{O}$ afforded octamer-amine $\mathbf{S 2 9}$ as a pale yellow solid (563 $\mathrm{mg}, 97 \%$ ) that was used without further purification. HRMS calculated for $\mathrm{C}_{131} \mathrm{H}_{154} \mathrm{~N}_{16} \mathrm{O}_{41} \mathrm{P}_{8}$ : 1428.42 $(\mathrm{M}+2 \mathrm{H})^{2+}$; Found: 1428.42. Analytical HPLC profile: see section 3.8.7.<smiles>CCOP(=O)(COc1cccc(C(=O)Nc2cccc3c(OCP(=O)(OCC)OCC)cc(C(=O)Nc4cc(C(C)(C)O)nc5c(CNC(C)(C)C)cccc45)nc23)c1)OCC</smiles>

Octamer-acid S30. Following the protocol described for the synthesis of acid S27. Amounts used: octamer S28 (600 mg, $0.203 \mathrm{mmol}), 10 \%$ Pd/C (120 mg, 20\% wt), THF (20 mL), iPrOH (10 mL). Octamer-acid S30 was obtained as a pale yellow solid (564 mg, 94\%) and used without further purification. HRMS calculated for $\mathrm{C}_{129} \mathrm{H}_{155} \mathrm{~N}_{16} \mathrm{O}_{43} \mathrm{P}_{8}: 2863.83(\mathrm{M}+\mathrm{H})^{+}$; Found: 2863.83. Analytical HPLC profile: see section 3.8.7. 


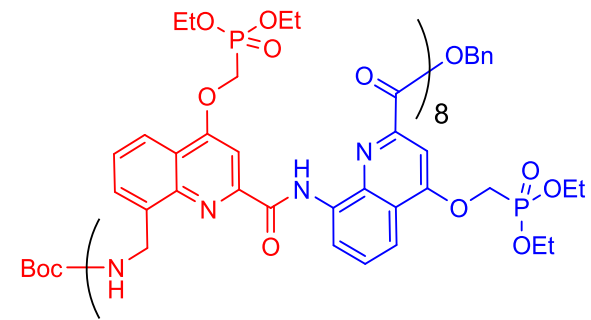

16mer S31. Following the protocol described for the synthesis of tetramer S25. Amounts used: octamer-acid S30 (165 mg, $58 \mu \mathrm{mol}$ ), octamer-amine S29 (165 mg, $58 \mu \mathrm{mol}, 1$ equiv.), HBTU (42 $\mathrm{mg}, 116 \mu \mathrm{mol}, 2$ equiv.), DIPEA (68 $\mu \mathrm{L}, 0.40 \mathrm{mmol}, 7$ equiv.), $\mathrm{CHCl}_{3}(1 \mathrm{~mL}$ for acid solution, $1 \mathrm{~mL}$ for amine solution, $1 \mathrm{~mL}$ for washing). In addition to the original protocol, the reaction mixture was filtered through celite prior to aqueous workup. Crystallization from DCM/Et2O afforded compound $\mathbf{S 3 1}$ as a pale yellow solid $(310 \mathrm{mg}, 95 \%) .{ }^{1} \mathrm{H}$ NMR $\left(300 \mathrm{MHz}, \mathrm{CDCl}_{3}\right) \delta 11.18(\mathrm{~s}, 1 \mathrm{H})$, $10.97(\mathrm{~s}, 1 \mathrm{H}), 10.15(\mathrm{~s}, 1 \mathrm{H}), 10.04(\mathrm{~s}, 1 \mathrm{H}), 9.86(\mathrm{~s}, 1 \mathrm{H}), 9.85(\mathrm{~s}, 1 \mathrm{H}), 9.80(\mathrm{~s}, 1 \mathrm{H}), 9.78(\mathrm{~s}, 1 \mathrm{H})$, $9.15(\mathrm{~d}, J=8.6 \mathrm{~Hz}, 1 \mathrm{H}), 9.06(\mathrm{~d}, J=10.6 \mathrm{~Hz}, 1 \mathrm{H}), 8.74(\mathrm{~d}, J=7.5 \mathrm{~Hz}, 1 \mathrm{H}), 8.64-8.48(\mathrm{~m}, 4 \mathrm{H})$, $8.38(\mathrm{dd}, J=7.3,1.4 \mathrm{~Hz}, 1 \mathrm{H}), 7.98-7.38(\mathrm{~m}, 20 \mathrm{H}), 7.34-6.87(\mathrm{~m}, 21 \mathrm{H}), 6.78-6.16(\mathrm{~m}, 27 \mathrm{H}), 5.42$ $(\mathrm{d}, J=12.3 \mathrm{~Hz}, 1 \mathrm{H}), 5.14(\mathrm{dd}, J=14.4,10.2 \mathrm{~Hz}, 1 \mathrm{H}), 5.05(\mathrm{~d}, J=12.5 \mathrm{~Hz}, 1 \mathrm{H}), 4.81-3.16(\mathrm{~m}$, 104H), 3.07-2.94 (m, 1H), $2.38(\mathrm{~d}, J=15.9 \mathrm{~Hz}, 1 \mathrm{H}), 2.27-2.04(\mathrm{~m}, 5 \mathrm{H}), 1.66-1.27$ (m, 96H), 1.04 $(\mathrm{s}, 9 \mathrm{H}) .{ }^{13} \mathrm{C}$ NMR $\left(75 \mathrm{MHz}, \mathrm{CDCl}_{3}\right) \delta 165.1,164.3,164.3,164.1,163.95,163.9,163.7,162.5$, $162.2,162.1,162.0,162.0,161.9,161.9,161.8,161.7,161.68,161.6,161.4,161.4,161.3,161.3$, $161.1,161.0,160.7,160.7,160.6,160.4,160.4,160.3,160.2,160.2,160.2,160.1,160.0,160.0$, $159.9,159.8,159.8,155.1,150.6,150.5,150.5,150.2,150.1,149.1,148.8,148.6,148.5,148.4$, $148.4,146.8,145.7,145.5,145.45,145.1,145.0,144.2,137.5,137.2,135.9,135.7,135.4,135.3$, $135.2,134.7,133.7,133.5,133.2,133.1,133.05,132.8,132.4,131.8,131.5,131.3,131.2,131.0$, $130.9,130.8,130.2,128.5,128.3,128.2,127.8,127.7,127.2,127.1,126.7,126.4,126.4,125.9$, $125.9,125.7,125.7,121.7,121.6,121.2,121.1,121.1,120.95,120.5,120.2,120.1,119.8,119.5$, $117.8,117.6,117.6,117.5,117.4,117.4,117.1,116.9,116.8,116.7,116.6,116.5,115.8,114.3$, 114.1, 114.1, 113.95, 99.7, 99.7, 98.8, 98.0, 97.96, 97.9, 97.8, 97.7, 97.6, 97.4, 97.2, 97.2, 97.1, $97.0,78.7,67.7,63.2,63.1,63.1,63.1,63.0,62.9,62.8,62.8,62.7,62.7,62.6,62.5,44.0,43.2$, 28.0, 16.8, 16.7, 16.6, 16.5, 16.4, 16.4. ${ }^{31} \mathrm{P}$ NMR (122 MHz, $\left.\mathrm{CDCl}_{3}\right) \delta 19.49,19.48,19.41(2 \mathrm{P})$, $19.38,18.94,18.76,18.12,18.02,17.94,17.77,17.73,17.70,17.67$ (2P), 17.45. Maldi MS calculated for $\mathrm{C}_{260} \mathrm{H}_{305} \mathrm{~N}_{32} \mathrm{O}_{83} \mathrm{P}_{16}: 5700.6(\mathrm{M}+\mathrm{H})^{+}$; Found: 5699.5. Analytical HPLC profile: see section 3.8.7.

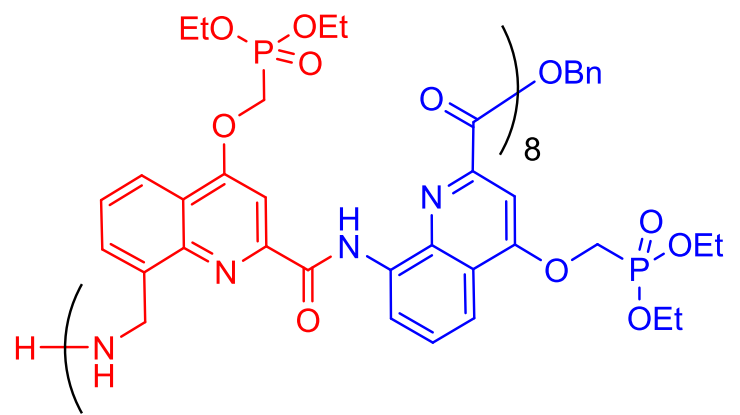

16mer-amine S32. Following the protocol described for the synthesis of amine S24. Amounts used: 16mer S31 (115 mg, $20 \mu \mathrm{mol})$, TFA (160 $\mu \mathrm{L}, 2 \mathrm{mmol}, 100$ equiv.), DCM (350 $\mu \mathrm{L}$, out of which $200 \mu \mathrm{L}$ was used to dissolve the compound and $150 \mu \mathrm{L}$ to dilute TFA). The crude product was recrystallised from $\mathrm{DCM} / \mathrm{Et}_{2} \mathrm{O}$ to yield 16 mer-amine $\mathbf{S 3 2}$ as a pale yellow solid (109 $\mathrm{mg}, 97 \%$ ). Maldi MS calculated for $\mathrm{C}_{255} \mathrm{H}_{297} \mathrm{~N}_{32} \mathrm{O}_{81} \mathrm{P}_{16}: 5601(\mathrm{M}+\mathrm{H})^{+}$; Found: 5602. Analytical HPLC profile: see section 3.8.7. 


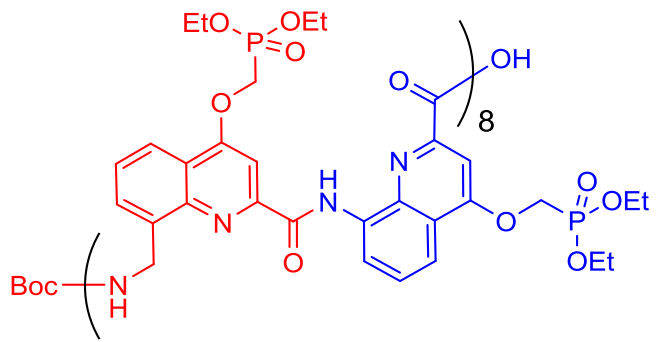

16mer-acid S33. Following the protocol described for the synthesis of acid S27, amounts used: 16mer S31 (115 mg, $20 \mu \mathrm{mol}), 10 \%$ Pd/C (23mg, 20\% wt), THF (15 mL), iPrOH (15 mL). 16meracid S33 was obtained as a pale yellow solid (109 mg, 97\%) that was used without further purification. Maldi MS calculated for $\mathrm{C}_{253} \mathrm{H}_{299} \mathrm{~N}_{32} \mathrm{O}_{83} \mathrm{P}_{16}: 5610(\mathrm{M}+\mathrm{H})^{+}$; Found: 5612. Analytical HPLC profile: see section 3.8.7.<smiles>CCOP(=O)(COc1cc(C(=O)Nc2cccc3c(OCP(=O)(OCC)OCC)cc(C(=O)C(C)(C)OCc4ccccc4)nc23)nc2c(CNC(C)(C)C(C)(C)C)cccc12)OCC</smiles>

24mer S34. The reaction flask was charged with 16 mer-amine $\mathbf{S 3 2}$ (128 mg, $23 \mu \mathrm{mol})$ and octameracid $\mathbf{S 3 0}$ (66 mg, $23 \mu \mathrm{mol}, 1$ equiv.) and flushed with nitrogen. Then $\mathrm{CHCl}_{3}(1 \mathrm{~mL})$ was added, immediately followed by PyBOP (12 mg, $24 \mu \mathrm{mol}, 1.05$ equiv.) and DIPEA (10 $\mu \mathrm{L}, 58 \mu \mathrm{mol}, 2.5$ equiv.) and the mixture was stirred for $20 \mathrm{~h}$ at room temperature under nitrogen. Then another portion of PyBOP (12 mg, $24 \mu \mathrm{mol}, 1.05$ equiv.), DIPEA $\left(10 \mu \mathrm{L}, 58 \mu \mathrm{mol}, 2.5\right.$ equiv.) and $\mathrm{CHCl}_{3}$ $(0.5 \mathrm{~mL})$ were added and the mixture was stirred for next $24 \mathrm{~h}$ under nitrogen. Completion of reaction was confirmed by RP-HPLC. The reaction mixture was diluted with $\mathrm{CHCl}_{3}$, washed with $5 \% \mathrm{wt} / \mathrm{vol}$ aqueous citric acid (x2), saturated aqueous sodium bicarbonate (x2), and brine (x1). The combined aqueous phases were back-extracted with $\mathrm{CHCl}_{3}$. The combined organic phases were dried over $\mathrm{Na}_{2} \mathrm{SO}_{4}$, filtered and evaporated under reduced pressure. The resulting residue was dissolved in EtOAc, and the resulting solution was filtered through celite and evaporated. Recrystallization from DCM/toluene/Et $2 \mathrm{O}$ followed by silica gel chromatography (DCM: EtOAc: $\mathrm{MeOH}$ 60:30:10 $\rightarrow$ DCM: MeOH 85:15) afforded S34 as a pale yellow solid (109 $\mathrm{mg}, 56 \%) .{ }^{1} \mathrm{H}$ $\operatorname{NMR}\left(300 \mathrm{MHz}, \mathrm{CDCl}_{3}\right) \delta 11.12(\mathrm{~s}, 1 \mathrm{H}), 10.93(\mathrm{~s}, 1 \mathrm{H}), 10.08(\mathrm{~s}, 1 \mathrm{H}), 9.94(\mathrm{~s}, 1 \mathrm{H}), 9.74(\mathrm{~s}, 1 \mathrm{H})$, $9.72(\mathrm{~s}, 1 \mathrm{H}), 9.66-9.50(\mathrm{~m}, 6 \mathrm{H}), 9.15(\mathrm{~d}, J=7.0 \mathrm{~Hz}, 1 \mathrm{H}), 9.06(\mathrm{~d}, J=9.6 \mathrm{~Hz}, 1 \mathrm{H}), 8.72(\mathrm{~d}, J=6.4$ $\mathrm{Hz}, 1 \mathrm{H}), 8.62-8.37(\mathrm{~m}, 8 \mathrm{H}), 8.33(\mathrm{dd}, J=6.9,1.5 \mathrm{~Hz}, 1 \mathrm{H}), 7.98-5.96(\mathrm{~m}, 100 \mathrm{H}), 5.39(\mathrm{~d}, J=12.3$ $\mathrm{Hz}, 1 \mathrm{H}), 5.20-5.06(\mathrm{~m}, 1 \mathrm{H}), 5.02(\mathrm{~d}, J=12.3 \mathrm{~Hz}, 1 \mathrm{H}), 4.82-2.88(\mathrm{~m}, 155 \mathrm{H}), 2.19-1.83(\mathrm{~m}, 12 \mathrm{H})$, 1.64- $1.19(\mathrm{~m}, 144 \mathrm{H}), 1.01$ (s, 9H). ${ }^{31} \mathrm{P}$ NMR $\left(122 \mathrm{MHz}, \mathrm{CDCl}_{3}\right) \delta 19.32,19.28$ - $19.16(7 \mathrm{P}), 18.84$, 18.77, 18.01 (2P), 17.92, 17.72, 17.64 - 17.57 (5P), 17.61, 17.56, 17.45. Maldi MS calculated for $\mathrm{C}_{384} \mathrm{H}_{449} \mathrm{~N}_{48} \mathrm{O}_{123} \mathrm{P}_{24}: 8447(\mathrm{M}+\mathrm{H})^{+}$; Found: 8448. Analytical HPLC profile: see section 3.8.7. 


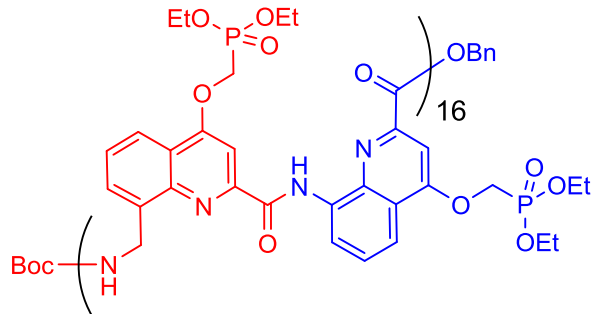

32mer S35. The reaction flask was charged with $16 \mathrm{mer}$-amine S32 (90 mg, 16 $\mu \mathrm{mol})$, $16 \mathrm{mer}-\mathrm{acid}$ S33 (90mg, 16 $\mu \mathrm{mol}$ ) and PyBOP (17 mg, $32 \mu \mathrm{mol}, 2$ equiv.) and flushed with nitrogen. Then $\mathrm{CHCl}_{3}(1 \mathrm{~mL})$ was added, immediately followed by DIPEA $(14 \mu \mathrm{L}, 112 \mu \mathrm{mol}, 5$ equiv.) and the mixture was stirred for $48 \mathrm{~h}$ at room temperature under nitrogen. Completion of the reaction was confirmed by RP-HPLC. The reaction mixture was diluted with $\mathrm{CHCl}_{3}$, washed with $5 \% \mathrm{wt} / \mathrm{vol}$ aqueous citric acid (x2), saturated aqueous sodium bicarbonate (x2), and brine (x1). The combined aqueous phases were back-extracted with $\mathrm{CHCl}_{3}$. The combined organic phases were dried over $\mathrm{Na}_{2} \mathrm{SO}_{4}$, filtered and solvents were removed under reduced pressure. Some byproducts and excess reagents were precipitated from DCM/ EtOAc and removed by filtration through celite. The filtrate was evaporated. Crystallization from DCM/Et ${ }_{2} \mathrm{O}$ and recrystallization from DCM/toluene/Et ${ }_{2} \mathrm{O}$ yielded the title compound $\mathbf{S 3 5}\left(125 \mathrm{mg}, 69 \%\right.$ yield). ${ }^{1} \mathrm{H}$ NMR $\left(400 \mathrm{MHz}, \mathrm{CDCl}_{3}\right) \delta 11.12(\mathrm{~s}, 1 \mathrm{H})$, $10.92(\mathrm{~s}, 1 \mathrm{H}), 10.07(\mathrm{~s}, 1 \mathrm{H}), 9.94(\mathrm{~s}, 1 \mathrm{H}), 9.74(\mathrm{~s}, 1 \mathrm{H}), 9.72(\mathrm{~s}, 1 \mathrm{H}), 9.66-9.40(\mathrm{~m}, 10 \mathrm{H}), 9.13(\mathrm{~d}$, $J=5.1 \mathrm{~Hz}, 1 \mathrm{H}), 9.04(\mathrm{~d}, J=8.7 \mathrm{~Hz}, 1 \mathrm{H}), 8.70(\mathrm{brs}, 1 \mathrm{H}), 8.60-8.24(\mathrm{~m}, 12 \mathrm{H}), 7.96-5.90(\mathrm{~m}, 133 \mathrm{H})$, $5.39(\mathrm{~d}, J=11.8 \mathrm{~Hz}, 1 \mathrm{H}), 5.15-5.05(\mathrm{~m}, 1 \mathrm{H}), 5.02(\mathrm{~d}, J=11.9 \mathrm{~Hz}, 1 \mathrm{H}), 4.75-2.91(\mathrm{~m}, 209 \mathrm{H})$, $2.15-1.80(\mathrm{~m}, 14 \mathrm{H}), 1.66-1.21(\mathrm{~m}, 192 \mathrm{H}), 1.01(\mathrm{~s}, 9 \mathrm{H}) .{ }^{31} \mathrm{P}$ NMR $\left(122 \mathrm{MHz}, \mathrm{CDCl}_{3}\right) \delta 19.48-$ 19.18 (13P), 18.92, 18.79, 18.07, 18.04, 17.96, 17.77, 17.71, 17.69 - 17.57 (11P), 17.48. Maldi MS calculated for $\mathrm{C}_{508} \mathrm{H}_{593} \mathrm{~N}_{64} \mathrm{O}_{163} \mathrm{P}_{32}: 11193(\mathrm{M}+\mathrm{H})^{+}$; Found: 11190. Analytical HPLC profile: see section 3.8.7.

\section{Synthesis of the oligomers in the $\left({ }^{\mathrm{m}} \mathrm{QQ} \mathrm{Q}^{5}\right)_{\mathrm{n}}$ series}

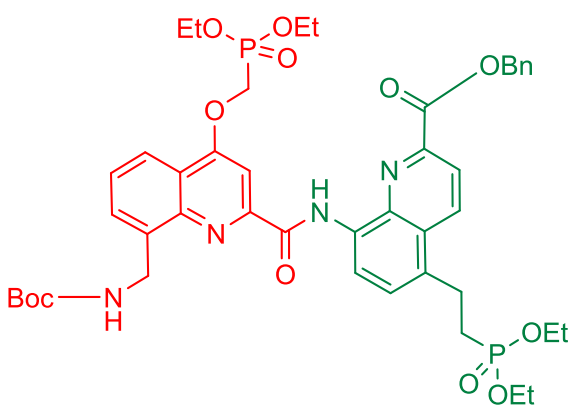

Dimer S36. To a dry flask containing acid S5 (2.84 mmol, $1.33 \mathrm{~g}$ ), amine S19 (1.26 g, $2.84 \mathrm{mmol}, 1$ equiv.) and PyBOP (2.96 g, $5.69 \mathrm{mmol}, 2$ equiv.), $20 \mathrm{~mL}$ of dry $\mathrm{CHCl}_{3}$ was added followed by DIPEA (3.47 mL, $19.9 \mathrm{mmol}, 7$ equiv.) at room temperature under nitrogen. The mixture was stirred for $22 \mathrm{~h}$ under nitrogen. An additional $93 \mathrm{mg}(0.20 \mathrm{mmol}, 0.07$ equiv.) of acid $\mathbf{S 5}$ was added and the stirring was continued for another $6 \mathrm{~h}$. Completion of reaction was confirmed by ${ }^{1} \mathrm{H}$ NMR of an aliquot. The mixture was diluted with $\mathrm{CHCl}_{3}$, washed with $5 \% \mathrm{wt} / \mathrm{vol}$ aqueous citric acid (x3), saturated sodium bicarbonate (x1) and brine (x1). The combined aqueous phases were backextracted with $\mathrm{CHCl}_{3}$. The combined organic phases were dried over $\mathrm{Na}_{2} \mathrm{SO}_{4}$, filtered and solvents were evaporated in vacuo. Some byproducts and excess reagents were precipitated from EtOAc and removed by filtration through celite. Evaporation of the filtrate yielded the crude product as a brownish oil. Silica gel chromatographic purification (cyclohexane:acetone 50:50 $\rightarrow 0: 100$ ) and recrystallization from $\mathrm{DCM} / \mathrm{Et}_{2} \mathrm{O}$ yielded the title compound as a pale yellow solid $(1.85 \mathrm{~g}, 73 \%)$. ${ }^{1} \mathrm{H}$ NMR $\left(300 \mathrm{MHz}, \mathrm{CDCl}_{3}\right) \delta 12.45(\mathrm{~s}, 1 \mathrm{H}), 9.06(\mathrm{~d}, J=7.9 \mathrm{~Hz}, 1 \mathrm{H}), 8.57(\mathrm{~d}, J=8.8 \mathrm{~Hz}, 1 \mathrm{H})$, 
8.32-8.22 (m, 2H), $7.95-7.78(\mathrm{~m}, 2 \mathrm{H}), 7.69-7.33$ (m, 7H), 5.75 (brs, $1 \mathrm{H}), 5.59$ (s, 2H), 5.27 (brs, $2 \mathrm{H}), 4.66(\mathrm{~d}, J=10.3 \mathrm{~Hz}, 2 \mathrm{H}), 4.35(\mathrm{dq}, J=8.3,7.1 \mathrm{~Hz}, 4 \mathrm{H}), 4.25-4.10(\mathrm{~m}, 4 \mathrm{H}), 3.47-3.35(\mathrm{~m}$, 2H), $2.28-2.10(\mathrm{~m}, 2 \mathrm{H}), 1.44(\mathrm{t}, J=7.1 \mathrm{~Hz}, 6 \mathrm{H}), 1.40(\mathrm{~s}, 9 \mathrm{H}), 1.38(\mathrm{t}, J=7.1 \mathrm{~Hz}, 6 \mathrm{H}) .{ }^{13} \mathrm{C} \mathrm{NMR}$ $\left(75 \mathrm{MHz}, \mathrm{CDCl}_{3}\right) \delta 164.2,163.0,162.8,156.7,150.3,145.98,145.8,139.2,138.2,135.7,134.2$, 133.4, 131.4, 131.2, 129.9, 128.9, 128.7, 128.4, 128.4, 127.4, 121.8, 121.5, 120.7, 117.1, 98.1, 79.0, 67.6, 63.6, 63.2, 63.1, 61.9, 61.8, 61.3, 41.5, 28.5, 27.8, 26.0, 24.9, 24.8, 16.6, 16.6, 16.5, 16.5. ${ }^{31} \mathrm{P}$ NMR $\left(122 \mathrm{MHz}, \mathrm{CDCl}_{3}\right) \delta 30.19,17.81$. HRMS calculated for $\mathrm{C}_{44} \mathrm{H}_{55} \mathrm{~N}_{4} \mathrm{O}_{12} \mathrm{P}_{2}: 893.3286(\mathrm{M}+\mathrm{H})^{+}$; Found: 893.3284.

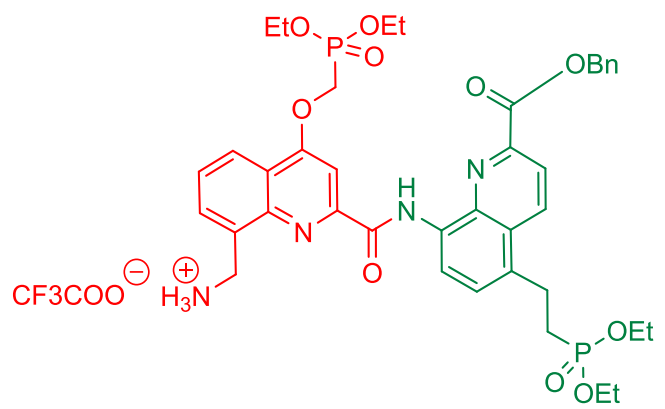

Dimer-amine S37. Following the protocol described for the synthesis of amine S24. Amounts used: Dimer S31 (893 mg, $1.00 \mathrm{mmol}$ ), TFA (1.54 mL, $20 \mathrm{mmol}, 20$ equiv.), DCM (3 mL). The crude product was recrystallised from DCM/Et $2 \mathrm{O}$ to yield dimer-amine $\mathbf{S 3 7}$ as a pale yellow solid $(681 \mathrm{mg}, 86 \%)$ that was used immediately without further purification. ${ }^{1} \mathrm{H}$ NMR $(300 \mathrm{MHz}$, DMSO-d $\left._{6}\right) \delta 12.28(\mathrm{~s}, 1 \mathrm{H}), 8.98(\mathrm{~d}, J=8.0 \mathrm{~Hz}, 1 \mathrm{H}), 8.76(\mathrm{~d}, J=8.8 \mathrm{~Hz}, 1 \mathrm{H}), 8.33(\mathrm{~d}, J=8.8 \mathrm{~Hz}$, $1 \mathrm{H}), 8.12(\mathrm{~d}, J=7.6 \mathrm{~Hz}, 1 \mathrm{H}), 8.03-7.96(\mathrm{~m}, 2 \mathrm{H}), 7.82-7.74(\mathrm{~m}, 2 \mathrm{H}), 7.56(\mathrm{dd}, J=7.6,1.7 \mathrm{~Hz}$, 2H), 7.41-7.29 (m, 3H), $5.64(\mathrm{~s}, 2 \mathrm{H}), 5.00(\mathrm{~d}, J=9.8 \mathrm{~Hz}, 2 \mathrm{H}), 4.75(\mathrm{~s}, 2 \mathrm{H}), 4.29-4.18(\mathrm{~m}, 4 \mathrm{H})$, 4.09-3.97 (m, 4H), 2.27-2.13 (m, 2H), $1.32(\mathrm{t}, J=7.0 \mathrm{~Hz}, 5 \mathrm{H}), 1.24(\mathrm{t}, J=7.0 \mathrm{~Hz}, 5 \mathrm{H})$. HRMS calculated for $\mathrm{C}_{39} \mathrm{H}_{47} \mathrm{~N}_{4} \mathrm{O}_{10} \mathrm{P}_{2}$ : $793.2762(\mathrm{M}+\mathrm{H})^{+}$; Found: 793.2764 .

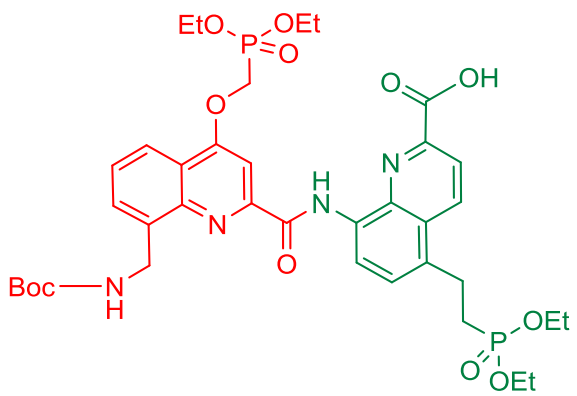

Dimer-acid S38. Following the protocol described for the synthesis of acid S27. Amounts used: dimer S36 (800 mg, $0.896 \mathrm{mmol}), 10 \% \mathrm{Pd} / \mathrm{C}(80 \mathrm{mg})$, THF (25 mL), iPrOH (25mL). Dimer-acid S38 was obtained as a pale yellow solid (699 $\mathrm{mg}, 91 \%)$ and used in the next step without further purification. ${ }^{1} \mathrm{H}$ NMR $\left(300 \mathrm{MHz}, \mathrm{CDCl}_{3}\right) \delta 12.31(\mathrm{~s}, 1 \mathrm{H}), 9.06(\mathrm{~d}, J=8.0 \mathrm{~Hz}, 1 \mathrm{H}), 8.61(\mathrm{~d}, J=8.8$ $\mathrm{Hz}, 1 \mathrm{H}), 8.36(\mathrm{~d}, J=8.7 \mathrm{~Hz}, 1 \mathrm{H}), 8.31(\mathrm{dd}, J=7.4,1.1 \mathrm{~Hz}, 1 \mathrm{H}), 7.99(\mathrm{~s}, 1 \mathrm{H}), 7.84(\mathrm{~d}, J=6.7 \mathrm{~Hz}$, $1 \mathrm{H}), 7.69-7.60(\mathrm{~m}, 2 \mathrm{H}), 5.35$ (brs, $2 \mathrm{H}), 5.06$ (brs, $1 \mathrm{H}), 4.67(\mathrm{~d}, J=10.4 \mathrm{~Hz}, 2 \mathrm{H}), 4.41-4.29(\mathrm{~m}$, $4 \mathrm{H}), 4.26-4.11(\mathrm{~m}, 4 \mathrm{H}), 3.49-3.37(\mathrm{~m}, 2 \mathrm{H}), 2.29-2.14(\mathrm{~m}, 2 \mathrm{H}), 1.44(\mathrm{t}, J=7.1 \mathrm{~Hz}, 6 \mathrm{H}), 1.41(\mathrm{~s}$, $9 \mathrm{H}), 1.39$ (d, $J=7.1 \mathrm{~Hz}, 6 \mathrm{H})$. HRMS calculated for $\mathrm{C}_{37} \mathrm{H}_{47} \mathrm{~N}_{4} \mathrm{O}_{12} \mathrm{P}_{2}: 801.2671(\mathrm{M}-\mathrm{H})^{-}$; Found: 801.2676. 


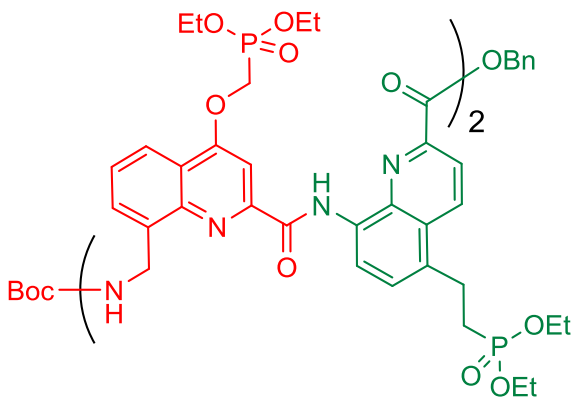

Tetramer S39. Following the protocol described for the synthesis of tetramer S25. Amounts used: dimer-acid S38 (474 mg, 0.590 mmol), dimer-amine S37 (468 mg, $0.590 \mathrm{mmol}, 1$ equiv.), HBTU (463 mg, $1.18 \mathrm{mmol}, 2$ equiv.), DIPEA (745 $\mu \mathrm{L}, 4.13 \mathrm{mmol}, 7$ equiv.), $\mathrm{CHCl}_{3}$ (10 $\mathrm{mL}$ for acid solution, $4 \mathrm{~mL}$ for amine solution, $3 \mathrm{~mL}$ for washing). In addition to the original protocol, the reaction mixture was filtered through a celite pad prior to aqueous workup. Crystallization followed by silica gel chromatography afforded the title compound as a yellow solid $(872 \mathrm{mg}, 94 \%) .{ }^{1} \mathrm{H}$ $\operatorname{NMR}\left(300 \mathrm{MHz}, \mathrm{CDCl}_{3}\right) \delta 12.00(\mathrm{~s}, 1 \mathrm{H}), 11.49(\mathrm{~s}, 1 \mathrm{H}), 9.83(\mathrm{t}, J=5.8 \mathrm{~Hz}, 1 \mathrm{H}), 8.79(\mathrm{~d}, J=8.0$ $\mathrm{Hz}, 1 \mathrm{H}), 8.30-8.15(\mathrm{~m}, 4 \mathrm{H}), 8.13(\mathrm{dd}, J=8.5,1.2 \mathrm{~Hz}, 1 \mathrm{H}), 8.04(\mathrm{~d}, J=6.8 \mathrm{~Hz}, 1 \mathrm{H}), 7.90(\mathrm{~d}, J=$ $8.8 \mathrm{~Hz}, 1 \mathrm{H}), 7.82(\mathrm{~s}, 1 \mathrm{H}), 7.70(\mathrm{t}, J=7.6 \mathrm{~Hz}, 1 \mathrm{H}), 7.55(\mathrm{~d}, J=3.7 \mathrm{~Hz}, 1 \mathrm{H}), 7.54-7.31(\mathrm{~m}, 7 \mathrm{H}), 7.21$ $(\mathrm{d}, J=8.0 \mathrm{~Hz}, 1 \mathrm{H}), 6.97(\mathrm{~d}, J=6.8 \mathrm{~Hz}, 1 \mathrm{H}), 6.84(\mathrm{~s}, 1 \mathrm{H}), 5.52(\mathrm{~d}, J=6.0 \mathrm{~Hz}, 2 \mathrm{H}), 5.48(\mathrm{~s}, 2 \mathrm{H})$, $4.82(\mathrm{~d}, J=10.2 \mathrm{~Hz}, 2 \mathrm{H}), 4.50-4.33(\mathrm{~m}, 8 \mathrm{H}), 4.30-4.14(\mathrm{~m}, 8 \mathrm{H}), 4.02(\mathrm{t}, J=5.9 \mathrm{~Hz}, 1 \mathrm{H}), 3.93(\mathrm{~d}$, $J=5.7 \mathrm{~Hz}, 2 \mathrm{H}), 3.27-3.12(\mathrm{~m}, 4 \mathrm{H}), 2.19-1.99(\mathrm{~m}, 4 \mathrm{H}), 1.52(\mathrm{t}, J=7.1 \mathrm{~Hz}, 6 \mathrm{H}), 1.51(\mathrm{t}, J=7.1$ $\mathrm{Hz}, 6 \mathrm{H}), 1.43(\mathrm{t}, J=7.0 \mathrm{~Hz}, 6 \mathrm{H}), 1.41(\mathrm{t}, J=7.0 \mathrm{~Hz}, 6 \mathrm{H}), 1.24(\mathrm{~s}, 9 \mathrm{H}) .{ }^{13} \mathrm{C} \mathrm{NMR}\left(75 \mathrm{MHz}, \mathrm{CDCl}_{3}\right)$ $\delta 165.4,163.3,162.9,162.7,162.6,162.4,162.1,161.2,155.5,150.6,150.3,149.1,146.6,144.7$, 144.4, 138.1, 137.1, 136.6, 135.7, 135.5, 133.6, 133.1, 132.8, 131.95, 131.24, 131.1, 130.9, 130.8, $130.7,129.0,128.6,128.3,127.5,127.2,126.4,126.3,122.2,121.97,121.6,120.4,119.9,116.95$, 116.1, 99.1, 97.4, 79.1, 67.7, 63.9, 63.26, 63.2, 63.1, 61.9, 61.8, 61.7, 60.8, 53.4, 43.8, 40.4, 28.2, 28.1, 27.8, 26.2, 26.0, 24.8, 24.6, 16.7. ${ }^{31} \mathrm{P}$ NMR $\left(122 \mathrm{MHz}, \mathrm{CDCl}_{3}\right) \delta 30.17,29.84,17.98,17.83$. HRMS calculated for $\mathrm{C}_{76} \mathrm{H}_{93} \mathrm{~N}_{8} \mathrm{O}_{21} \mathrm{P}_{4}: 1577.5400(\mathrm{M}+\mathrm{H})^{+}$; Found: 1577.5409.

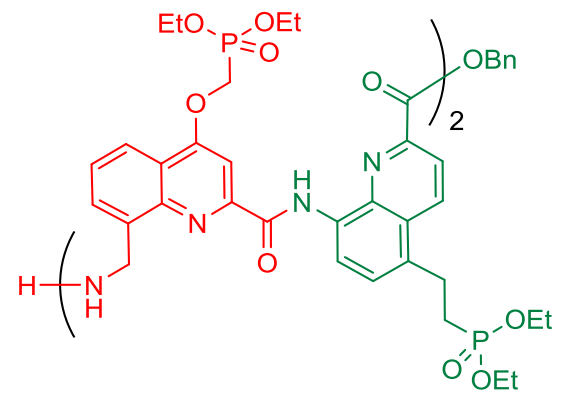

Tetramer-amine S40. Tetramer S39 (550 mg, $0.35 \mathrm{mmol})$ was dissolved in DCM (2.5 mL) and the solution was cooled to $0{ }^{\circ} \mathrm{C}$. Then TFA $(1.35 \mathrm{~mL}, 17.5 \mathrm{mmol}, 50$ equiv.) was added dropwise over $20 \mathrm{~min}$ at $0{ }^{\circ} \mathrm{C}$ with stirring. Cooling was removed and the reaction was stirred for $3 \mathrm{~h}$ at room temperature. After completion of the reaction (based on TLC), the solvents were evaporated under reduced pressure, and then co-evaporated with DCM (x2) and with $\mathrm{Et}_{2} \mathrm{O}$ (x2). The residue was dried on the vacuum line. Amine S40 (TFA salt) was obtained as a yellow glassy solid (819 mg) and used without further purification. ${ }^{1} \mathrm{H}$ NMR $\left(300 \mathrm{MHz}, \mathrm{CDCl}_{3}\right) \delta 12.12(\mathrm{~s}, 1 \mathrm{H}), 11.74(\mathrm{~s}, 1 \mathrm{H})$, $9.56(\mathrm{t}, J=5.8 \mathrm{~Hz}, 1 \mathrm{H}), 8.91(\mathrm{~d}, J=8.0 \mathrm{~Hz}, 1 \mathrm{H}), 8.56(\mathrm{~d}, J=7.8 \mathrm{~Hz}, 1 \mathrm{H}), 8.33(\mathrm{~d}, J=8.3 \mathrm{~Hz}, 1 \mathrm{H})$, 8.27-7.51 (m, 14H), $7.44(\mathrm{~s}, 1 \mathrm{H}), 7.36-7.32(\mathrm{~m}, 3 \mathrm{H}), 5.58(\mathrm{~d}, J=5.5 \mathrm{~Hz}, 2 \mathrm{H}), 5.34(\mathrm{~d}, J=4.6 \mathrm{~Hz}$, $2 \mathrm{H}), 4.74(\mathrm{~d}, J=10.2 \mathrm{~Hz}, 2 \mathrm{H}), 4.55-4.32(\mathrm{~m}, 10 \mathrm{H}), 4.30-4.09(\mathrm{~m}, 10 \mathrm{H}), 3.34-3.21(\mathrm{~m}, 2 \mathrm{H}), 3.19-$ $3.06(\mathrm{~m}, 2 \mathrm{H}), 2.30-2.13(\mathrm{~m}, 2 \mathrm{H}), 2.13-1.96(\mathrm{~m}, 2 \mathrm{H}), 1.54-1.32(\mathrm{~m}, 24 \mathrm{H}) .{ }^{31} \mathrm{P}$ NMR $(122 \mathrm{MHz}$, $\left.\mathrm{CDCl}_{3}\right) \delta 30.70,30.53,17.93,17.67$. HRMS calculated for $\mathrm{C}_{71} \mathrm{H}_{85} \mathrm{~N}_{8} \mathrm{O}_{19} \mathrm{P}_{4}: 1477.4876(\mathrm{M}+\mathrm{H})^{+}$; Found: 1477.4874. Analytical HPLC profile: see section 3.8.7. 


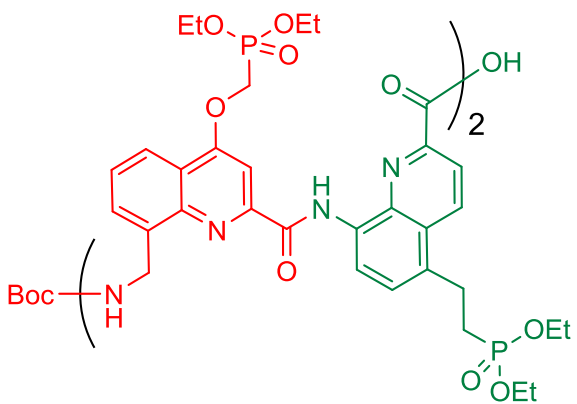

Tetramer-acid S41. Following the protocol described for the synthesis of acid S27. Amounts used: tetramer S39 (537 mg, $0.34 \mathrm{mmol}), \mathrm{Pd} / \mathrm{C}$ (10\% wt/wt, $54 \mathrm{mg})$, THF (15 mL), iPrOH (15 mL). The reaction took 4 days, an additional $54 \mathrm{mg}$ of $\mathrm{Pd} / \mathrm{C}$ was added after the second day. Tetramer-acid S41 was obtained as a pale yellow solid (431 mg, 85\% yield) that was used without further purification. HRMS calculated for $\mathrm{C}_{69} \mathrm{H}_{85} \mathrm{~N}_{8} \mathrm{O}_{21} \mathrm{P}_{4}$ : 1485.4785 (M-H) ${ }^{-}$; Found: 1485.4783. Analytical HPLC profile: see section 3.8.7.

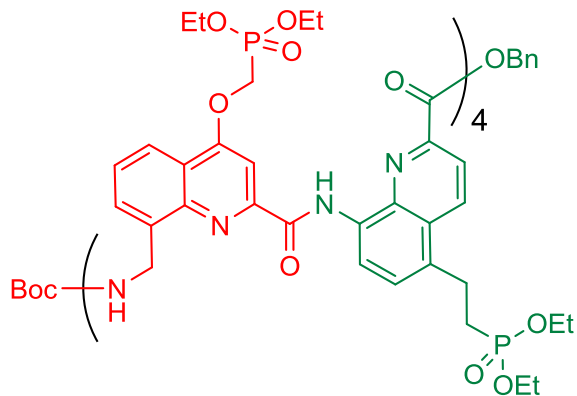

Octamer S42. Following the protocol described for the synthesis of tetramer S25. Amounts used: tetramer-acid $\mathbf{S 4 1}$ (380 mg, $0.255 \mathrm{mmol}$ ), tetramer-amine $\mathbf{S 4 0}$ (1.0 equiv., calculated for $\mathbf{S 4 0}$ with 7.5 TFA, 596mg), HBTU (193 mg, $0.511 \mathrm{mmol}, 2$ equiv.), DIPEA (890 $\mu \mathrm{L}, 5.11 \mathrm{mmol}, 20$ equiv.), $\mathrm{CHCl}_{3}$ ( $4 \mathrm{~mL}$ for acid solution, $2 \mathrm{~mL}$ for amine solution, $3 \mathrm{~mL}$ for washing). In addition to the original protocol, the reaction mixture was filtered through celite prior to aqueous workup. Octamer S42 was purified by silica gel column chromatography using DCM:EtOAc:MeOH $(10: 80: 10 \rightarrow 30: 60: 10)$ followed by recrystallization from $\mathrm{DCM} / \mathrm{Et}_{2} \mathrm{O}$ to yield a pale yellow solid (579 mg, 77\%). ${ }^{1} \mathrm{H}$ NMR (300 MHz, $\left.\mathrm{CD}_{3} \mathrm{CN}\right) \delta 11.57$ (s, 1H), 10.87 (s, 1H), $10.75(\mathrm{~s}, 1 \mathrm{H}), 10.36$ $(\mathrm{s}, 1 \mathrm{H}), 9.13$ (brs, $2 \mathrm{H}), 8.65(\mathrm{t}, J=5.6 \mathrm{~Hz}, 1 \mathrm{H}), 8.38(\mathrm{~d}, J=7.9 \mathrm{~Hz}, 1 \mathrm{H}), 8.16-8.03(\mathrm{~m}, 2 \mathrm{H}), 7.99$ $(\mathrm{d}, J=6.5 \mathrm{~Hz}, 1 \mathrm{H}), 7.85(\mathrm{t}, J=8.1 \mathrm{~Hz}, 1 \mathrm{H}), 7.81-7.27(\mathrm{~m}, 22 \mathrm{H}), 7.27-7.14(\mathrm{~m}, 4 \mathrm{H}), 7.10(\mathrm{~d}, J=$ $7.8 \mathrm{~Hz}, 1 \mathrm{H}), 7.03(\mathrm{~d}, J=6.9 \mathrm{~Hz}, 1 \mathrm{H}), 6.82-6.61(\mathrm{~m}, 5 \mathrm{H}), 6.52(\mathrm{~s}, 1 \mathrm{H}), 5.20(\mathrm{brs}, 2 \mathrm{H}), 5.18(\mathrm{~s}, 2 \mathrm{H})$, $4.86(\mathrm{~d}, J=9.4 \mathrm{~Hz}, 2 \mathrm{H}), 4.62-96(\mathrm{~m}, 40 \mathrm{H}), 4.35-4.17(\mathrm{~m}, 3 \mathrm{H}), 4.16-3.98(\mathrm{~m}, 2 \mathrm{H}), 3.03-2.85(\mathrm{~m}$, $4 \mathrm{H}), 2.79-2.56(\mathrm{~m}, 4 \mathrm{H}), 1.94-1.73(\mathrm{~m}, 8 \mathrm{H}), 1.65(\mathrm{t}, J=7.0 \mathrm{~Hz}, 6 \mathrm{H}), 1.56(\mathrm{t}, J=7.1 \mathrm{~Hz}, 6 \mathrm{H}), 1.51$ $(\mathrm{t}, J=7.2 \mathrm{~Hz}, 6 \mathrm{H}), 1.49(\mathrm{t}, J=7.0 \mathrm{~Hz}, 6 \mathrm{H}), 1.45(\mathrm{t}, J=7.0 \mathrm{~Hz}, 6 \mathrm{H}), 1.43(\mathrm{t}, J=6.8 \mathrm{~Hz}, 6 \mathrm{H}), 1.34$ $(\mathrm{t}, J=7.1 \mathrm{~Hz}, 6 \mathrm{H}), 1.27(\mathrm{t}, J=7.1 \mathrm{~Hz}, 6 \mathrm{H}), 0.98(\mathrm{~s}, 9 \mathrm{H}) .{ }^{13} \mathrm{C} \mathrm{NMR}\left(75 \mathrm{MHz}, \mathrm{CD}_{3} \mathrm{CN}\right) \delta 164.0$, $163.96,163.1,162.4,162.3,162.1,161.9,161.9,161.7,161.5,160.4,160.0,159.7,155.2,150.7$, $150.23,149.9,149.8,147.6,146.85,146.2,145.0,144.7,143.9,143.8,137.2,136.2,135.96,135.8$, 135.5, 135.2, 135.0, 133.7, 133.0, 132.9, 132.7, 132.4, 132.1, 131.7, 131.5, 131.2, 131.1, 131.0, $130.8,130.6,130.5,129.7,129.6,129.4,129.3,128.8,128.5,128.1,127.9,127.5,127.4,127.2$, 127.1, 126.6, 126.4, 125.8, 125.75, 124.6, 124.4, 121.4, 121.3, 121.1, 121.0, 119.9, 118.3, 118.1, 117.7, 115.96, 115.8, 114.95, 99.1, 97.9, 97.4, 97.1, 77.9, 66.9, 63.6, 63.2, 63.1, 63.0, 62.9, 61.8, 61.76, 61.7, 61.68, 61.6, 61.5, 61.45, 61.0, 60.6, 43.2, 42.9, 42.4, 39.6, 27.3, 26.8, 26.5, 25.0, 24.65, $24.2,23.97,23.8,16.3,16.3,16.2,16.1,16.01,15.9,15.9,15.8 .{ }^{31} \mathrm{P}$ NMR $\left(122 \mathrm{MHz}, \mathrm{CD}_{3} \mathrm{CN}\right) \delta$ 
30.06, 29.83(2P), 29.54, 18.21, 18.06, 17.88, 17.48. HRMS calculated for $\mathrm{C}_{140} \mathrm{H}_{169} \mathrm{~N}_{16} \mathrm{O}_{39} \mathrm{P}_{8}$ : 2943.95 (M-H)-; Found: 2943.92. Analytical HPLC profile: see section 3.8.7.<smiles>CCOC(=O)c1ccc2c(CCP(=O)(OCC)OCC)ccc(NC(=O)c3cc(OCP(=O)(OCC)OCC)c4cccc(CN)c4n3)c2n1</smiles>

Octamer-amine S43. Following the protocol described for the synthesis of amine S40. Amounts used: octamer S42 (270 mg, $92 \mu \mathrm{mol})$, TFA ( $350 \mu \mathrm{L}, 4.6 \mathrm{mmol}, 50$ equiv.), DCM (700 $\mu \mathrm{L})$. Amine S43 was obtained as a yellow solid TFA salt $(374 \mathrm{mg})$ and used without further purification. HRMS calculated for $\mathrm{C}_{135} \mathrm{H}_{161} \mathrm{~N}_{16} \mathrm{O}_{37} \mathrm{P}_{8}: 2845.91(\mathrm{M}+\mathrm{H})^{+}$; Found: 2845.91. Analytical HPLC profile: see section 3.8.7.<smiles>CCOP(=O)(CCc1ccc(NC(=O)c2cc(OCC(C)(C)C(C)(C)C)c3cccc(CNC(C)(C)C)c3n2)c2nc(C(=O)C(C)(C)O)ccc12)OCC</smiles>

Octamer-acid S44. Following the protocol described for the synthesis of acid S27. Amounts used: octamer S42: (270 mg, $92 \mu \mathrm{mol}),(54 \mathrm{mg}, 10 \% \mathrm{wt} / \mathrm{wt})$, THF $(15 \mathrm{~mL})$, iPrOH $(15 \mathrm{~mL})$. The reaction took 2 days. Octamer-acid $\mathbf{S 4 4}$ was obtained as a pale yellow solid $(249 \mathrm{mg}, 95 \%)$ and used without further purification. HRMS calculated for $\mathrm{C}_{133} \mathrm{H}_{161} \mathrm{~N}_{16} \mathrm{O}_{39} \mathrm{P}_{8}$ : $2853.90(\mathrm{M}-\mathrm{H})^{-}$; Found: 2853.88. Analytical HPLC profile: see section 3.8.7.<smiles>CCOP(=O)(CCc1ccc(NC(=O)c2cc(OCP(=O)(OCC)OCC)c3cccc(CNC(C)(C)C(C)(C)C)c3n2)c2nc(C(=O)C(C)(Cc3ccccc3)C(=O)c3ccccc3)ccc12)OCC</smiles>

16mer S45. Following the protocol described for the synthesis of tetramer S25. Amounts used: octamer-acid S44 $(249 \mathrm{mg}, 87 \mu \mathrm{mol}$ ), octamer-amine S43 (1 equiv., calculated as a salt with 11TFA, $349 \mathrm{mg}$ ), HBTU (66 mg, $87 \mu \mathrm{mol}, 2$ equiv.), DIPEA (280 $\mu \mathrm{L}, 1.57 \mathrm{mmol}, 18$ equiv.), $\mathrm{CHCl}_{3}$ (2 $\mathrm{mL}$ for acid solution, $1 \mathrm{~mL}$ for amine solution, $1 \mathrm{~mL}$ for washing). In addition to the original protocol, the reaction mixture was filtered through celite prior to aqueous workup. Pure 16 mer $\mathbf{S 4 5}$ was obtained by crystallizations from $\mathrm{DCM} / \mathrm{Et}_{2} \mathrm{O}$ followed by recrystallization from $\mathrm{DCM} /$ toluene/Et $2 \mathrm{O}$ as a pale yellow solid $(265 \mathrm{mg}, 54 \%) .{ }^{1} \mathrm{H} \mathrm{NMR}\left(400 \mathrm{MHz}, \mathrm{CD}_{3} \mathrm{OH}\right.$, solvent suppression applied) $\delta 11.30(\mathrm{~s}, 1 \mathrm{H}), 10.90(\mathrm{~s}, 1 \mathrm{H}), 10.49(\mathrm{~s}, 1 \mathrm{H}), 10.17(\mathrm{~s}, 1 \mathrm{H}), 9.99(\mathrm{~s}, 2 \mathrm{H}), 9.95$ 
(s, 1H), $9.92(\mathrm{~s}, 1 \mathrm{H}), 9.34(\mathrm{~d}, J=3.5 \mathrm{~Hz}, 1 \mathrm{H}), 8.96(\mathrm{~d}, J=8.7 \mathrm{~Hz}, 1 \mathrm{H}), 8.73(\mathrm{~d}, J=6.7 \mathrm{~Hz}, 1 \mathrm{H})$, $8.54(\mathrm{~d}, J=7.1 \mathrm{~Hz}, 1 \mathrm{H}), 8.42(\mathrm{~d}, J=8.1 \mathrm{~Hz}, 1 \mathrm{H}), 8.34(\mathrm{~d}, J=10.4 \mathrm{~Hz}, 1 \mathrm{H}), 8.31(\mathrm{~d}, J=11.2 \mathrm{~Hz}$, $2 \mathrm{H}), 8.12(\mathrm{~d}, J=7.8 \mathrm{~Hz}, 1 \mathrm{H}), 8.00(\mathrm{~d}, J=8.2 \mathrm{~Hz}, 1 \mathrm{H}), 7.86-6.26(\mathrm{~m}, 67 \mathrm{H}), \sim 5.2-\sim 4.6$ (suppression region), $4.56-3.41(\mathrm{~m}, 16 \mathrm{H}), 3.02-2.14(\mathrm{~m}, 20 \mathrm{H}), 2.02-1.34(\mathrm{~m}, 100 \mathrm{H}), 1.27(\mathrm{td}, J=7.1,2.9 \mathrm{~Hz}$, $6 \mathrm{H}), 1.19(\mathrm{td}, J=7.1,2.9 \mathrm{~Hz}, 6 \mathrm{H}), 0.92(\mathrm{~s}, 9 \mathrm{H}) .{ }^{31} \mathrm{P} \mathrm{NMR}\left(122 \mathrm{MHz}, \mathrm{CD}_{3} \mathrm{OH}\right) \delta 31.10,30.91$, 30.90, 30.81, 30.79 (3P), 30.75, 19.21, 19.10, 18.81, 18.67 (3P), 18.58, 18.30. Analytical HPLC profile: see section 3.8.7.

\subsubsection{Synthesis of water soluble oligomers}

General procedure of deprotection of ethyl phophonate oligomers. CAUTION - trimethylsilyl bromide (TMSBr) is highly volatile and produces hydrogen bromide upon exposure to atmospheric moisture! The starting material (scale of reaction: $10-50 \mathrm{mg}$, only highest purity crystalline material should be used, as impurities significantly increase the reaction time and amount of side-products) was placed in a dried flask protected with a septum and purged with $\mathrm{N}_{2}$ for $30 \mathrm{~min}$. Then, freshly distilled chloroform was added (5 volumes with respect to TMSBr were used) and the mixture was cooled to $0^{\circ} \mathrm{C}$. To this was added dropwise a solution of TMSBr (10 equiv with respect to each functional group to be deprotected, including $\mathrm{C}$ - and $\mathrm{N}$-terminae, i.e. 100 equiv. for tetramer, 180 equiv. for octamer, 340 equiv. for $16 \mathrm{mer}, 500$ equiv. for $24 \mathrm{mer}$ and 660 equiv. for $32 \mathrm{mer}$ ) in chloroform (4 volumes with respect to TMSBr). Septum was quickly replaced with well-fitting glass stopper and protected with parafilm. The reaction was left stirring for 2-4 weeks. Aliquots were collected every 7 days to monitor the progress of reaction by HPLC. For the longest oligomers (24mer and 32mer) a second portion of TMSBr (50\% of initial amount) was added after 3 weeks of reaction. When the reaction was finished, it was evaporated by a careful flow of nitrogen. The flow of nitrogen out of the reaction mixture was bubbled through water to quench excess TMSBr. To the remaining solid, water was added and the mixture was stirred for $3 \mathrm{~h}$. It was basified with triethylamine, stirred for $10 \mathrm{~min}$ and filtered using a $45 \mu \mathrm{m}$ syringe filter. The clear yellow solution was freeze-dried and subjected to HPLC purification.

Preparative HPLC purification. Crude products $(3-10 \mathrm{mg}$ ) were purified by preparative HPLC, using a Varian Pursuit C18 column ( 21 x $250 \mathrm{~mm})$ equipped with a matching precolumn; detection was achieved at $\lambda=240 \mathrm{~nm}$ (preparative cell); mobile phases were as described below; gradient sequence: (0 min) 100\% "A", 0\%" B" $\rightarrow$ (2.1 min) 100\% "A", 0\% "B" $\rightarrow$ (15 min) 80\% "A", 20\% "B" $\rightarrow$ (20min) $0 \%$ "A", 100\% "B"; flow ramp: (0 min) $1 \mathrm{~mL} / \mathrm{min} \rightarrow(0.1 \mathrm{~min}) 1 \mathrm{~mL} / \mathrm{min} \rightarrow(2$ min) $19 \mathrm{~mL} / \mathrm{min}$.

Mobile phases " $\mathrm{A}$ " and " $\mathrm{B}$ " were prepared as described at the beginning of section 2. Fractions collected from preparative HPLC were analyzed by analytical HPLC. The relevant fractions were combined, freeze-dried and then, twice, redissolved in water and freeze-dried to remove most of triethylamine. The estimated yields varied between $40-60 \%$ depending on the particular batch of compound and were difficult to determine precisely because of unspecified residual amounts of triethylamine and the unknown hydration state of the sample.

Ion exchange procedure. Exchange of triethylammonium to ammonium cations was performed using Dowex 50W X4 (200-400 Mesh) resin. Empty flash chromatography cartridges were filled with $7.5 \mathrm{~mL}$ or $22.5 \mathrm{~mL}$ of a resin, corresponding to $8 \mathrm{mmol}$ or $24 \mathrm{mmol}$ of cation exchanging capability (manufacturer data), respectively. The resin preparation/regeneration consisted in washing with 5 volumes of $2 \mathrm{M} \mathrm{HCl}$, then 5 volumes of MilliQ water until a neutral $\mathrm{pH}$ is reached, then 5 volumes of $2 \mathrm{M}$ ammonium acetate (bio-grade) and then with 5 volumes of MilliQ water. The resin stayed wet all the time. Compounds were introduced as solutions in 300-500 $\mu \mathrm{L}$ of MilliQ water (followed by 2 washings with $300-500 \mu \mathrm{L}$ of water). Compounds were eluted from the column by washing with 10 or $30 \mathrm{~mL}$ of MilliQ water for $7.5 \mathrm{~mL}$ and $22.5 \mathrm{~mL}$ cartridges, respectively. The collected solutions were freeze dried, then remaining solids were dissolved in a small amount of water, transferred to a small vial, and freeze-dried again to afford the ammonium 
salts of the oligomers. The absence of triethyl-ammonium was confirmed by ${ }^{1} \mathrm{H}$ NMR. After regeneration, as described above, the resin was used again.

$\left({ }^{\mathrm{m}} \mathrm{QQ}^{4}\right)_{2}$ ammonium salt. ${ }^{1} \mathrm{H} \mathrm{NMR}\left(300 \mathrm{MHz}, \mathrm{H}_{2} \mathrm{O} / \mathrm{D}_{2} \mathrm{O}[9: 1 \mathrm{vol} / \mathrm{vol}], 50 \mathrm{mM} \mathrm{NH} 4 \mathrm{HCO}_{3}\right.$, 'watergate' water suppression applied at $4.71 \mathrm{ppm}$ which may cause errors in the observed peak intensities in the vicinity of the suppressed peak) $\delta 11.90(\mathrm{~s}, 1 \mathrm{H}), 11.70(\mathrm{~s}, 1 \mathrm{H}), 10.09(\mathrm{~s}, 1 \mathrm{H}), 8.55$ $(\mathrm{d}, \mathrm{J}=8.8 \mathrm{~Hz}, 1 \mathrm{H}), 8.41(\mathrm{~d}, \mathrm{~J}=7.9 \mathrm{~Hz}, 1 \mathrm{H}), 8.21(\mathrm{~d}, \mathrm{~J}=8.5 \mathrm{~Hz}, 1 \mathrm{H}), 8.01-7.34(\mathrm{~m}, 10 \mathrm{H}), 7.01(\mathrm{~s}$, 1H), $6.99(\mathrm{~s}, 1 \mathrm{H}), 6.65(\mathrm{~s}, 1 \mathrm{H}), 5.25(\mathrm{~s}), 4.32(\mathrm{~d}, \mathrm{~J}=8.5 \mathrm{~Hz}), 4.04(\mathrm{~d}, \mathrm{~J}=13.4 \mathrm{~Hz}), 3.91(\mathrm{~d}, \mathrm{~J}=21.3$ $\mathrm{Hz}) .{ }^{31} \mathrm{P}$ NMR $\left(122 \mathrm{MHz}, \mathrm{H}_{2} \mathrm{O} / \mathrm{D}_{2} \mathrm{O}[9: 1 \mathrm{vol} / \mathrm{vol}], 50 \mathrm{mM} \mathrm{NH} \mathrm{HCO}_{3}\right) \delta 12.30,12.03,11.47,11.01$. MALDI MS calculated for $\mathrm{C}_{46} \mathrm{H}_{43} \mathrm{~N}_{8} \mathrm{O}_{21} \mathrm{P}_{4}: 1167.1(\mathrm{M}+\mathrm{H})^{+}$; Found: 1168.1. Analytical HPLC profile: see section 3.8.7.

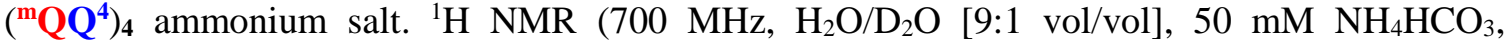
'watergate' water suppression applied at $4.72 \mathrm{ppm}$ which may cause errors in the observed peak intensities in the vicinity of the suppressed peak) $\delta 11.68(\mathrm{H}-\mathrm{NH}, \mathrm{s}, 1 \mathrm{H}), 11.19(\mathrm{~B}-\mathrm{NH}, \mathrm{s}, 1 \mathrm{H})$, 10.65 (F-NH, s, 1H), 10.22 (D-NH, s, 1H), 9.82 (C-NH, s, 1H), 9.12 (G-NH, s, 1H), 8.95 (E-NH, s, 1H), $8.38(\mathrm{~A}-\mathrm{H} 5, \mathrm{~d}, J=8.1 \mathrm{~Hz}, 1 \mathrm{H}), 8.27(\mathrm{G}-\mathrm{H} 5, \mathrm{~d}, J=8.0 \mathrm{~Hz}, 1 \mathrm{H}), 8.09(\mathrm{E}-\mathrm{H} 5, \mathrm{~d}, J=8.0 \mathrm{~Hz}$, $1 \mathrm{H}), 8.04(\mathrm{C}-\mathrm{H} 5, \mathrm{~d}, J=7.8 \mathrm{~Hz}, 1 \mathrm{H}), 8.03(\mathrm{H}-\mathrm{H} 7, \mathrm{~d}, J=7.8 \mathrm{~Hz}, 1 \mathrm{H}), 8.01(\mathrm{G}-\mathrm{H} 7, \mathrm{~d}, J=8.0 \mathrm{~Hz}$, 1H), $7.80(\mathrm{~B}-\mathrm{H} 7, \mathrm{~d}, J=7.0 \mathrm{~Hz}, 1 \mathrm{H}), 7.75(\mathrm{G}-\mathrm{H} 6, \mathrm{t}, J=7.4 \mathrm{~Hz}, 1 \mathrm{H}), 7.61(\mathrm{E}-\mathrm{H} 6, \mathrm{t}, J=7.2 \mathrm{~Hz}, 1 \mathrm{H})$, $7.60(\mathrm{~A}-\mathrm{H} 3, \mathrm{~s}, 1 \mathrm{H}), 7.53(\mathrm{H}-\mathrm{H} 5, \mathrm{~d}, J=7.0 \mathrm{~Hz}, 1 \mathrm{H}), 7.52(\mathrm{D}-\mathrm{H} 7, \mathrm{~d}, J=6.8 \mathrm{~Hz}, 1 \mathrm{H}), 7.44(\mathrm{C}-\mathrm{H} 6, \mathrm{t}$, $J=7.5 \mathrm{~Hz}, 1 \mathrm{H}), 7.43(\mathrm{~B}-\mathrm{H} 5, \mathrm{~d}, J=7.9 \mathrm{~Hz}, 1 \mathrm{H}), 7.34(\mathrm{~A}-\mathrm{H} 6, \mathrm{t}, J=7.4 \mathrm{~Hz}, 1 \mathrm{H}), 7.27(\mathrm{~F}-\mathrm{H} 7, \mathrm{~d}, J=$ $6.9 \mathrm{~Hz}, 1 \mathrm{H}), 7.20(\mathrm{H}-\mathrm{H} 6, \mathrm{~d}, J=7.5 \mathrm{~Hz}, 1 \mathrm{H}), 7.19(\mathrm{E}-\mathrm{H} 7, \mathrm{t}, \mathrm{J}=8.3 \mathrm{~Hz}, 1 \mathrm{H}), 7.12(\mathrm{D}-\mathrm{H} 5, \mathrm{~d}, J=7.9$ Hz, 1H), 7.08 (F-H5, t, $J=8.0 \mathrm{~Hz}, 1 \mathrm{H}), 7.07$ (B-H6, d, $J=6.5 \mathrm{~Hz}, 1 \mathrm{H}), 6.97(\mathrm{C}-\mathrm{H} 7, \mathrm{~d}, J=6.7 \mathrm{~Hz}$, $1 \mathrm{H}), 6.85(\mathrm{~B}-\mathrm{H} 3, \mathrm{~s}, 1 \mathrm{H}), 6.83(\mathrm{D}-\mathrm{H} 6, \mathrm{t}, J=8.1 \mathrm{~Hz}, 1 \mathrm{H}), 6.81(\mathrm{~F}-\mathrm{H} 6, \mathrm{t}, J=7.5 \mathrm{~Hz}, 1 \mathrm{H}), 6.73$ (DH3, s, 1H), $6.66(\mathrm{~F}-\mathrm{H} 3, \mathrm{~s}, 1 \mathrm{H}), 6.61(\mathrm{~A}-\mathrm{H} 7, \mathrm{~d}, J=6.7 \mathrm{~Hz}, 1 \mathrm{H}), 6.48(\mathrm{C}-\mathrm{H} 3, \mathrm{~s}, 1 \mathrm{H}), 6.47(\mathrm{H}-\mathrm{H} 3, \mathrm{~s}$, $1 \mathrm{H}), 6.42(\mathrm{G}-\mathrm{H} 3, \mathrm{~s}, 1 \mathrm{H}), 6.17(\mathrm{E}-\mathrm{H} 3, \mathrm{~s}, 1 \mathrm{H}), 5.06(\mathrm{G}-\mathrm{H} 12 \mathrm{a}, \mathrm{t}, J=12.8 \mathrm{~Hz}, 1 \mathrm{H}), 5.01(\mathrm{G}-\mathrm{H} 12 \mathrm{~b}, \mathrm{brs}$, $1 \mathrm{H}), 4.49$ (A-H12a, brs, 1H), $4.35(\mathrm{~A}-\mathrm{H} 12 \mathrm{~b}, \mathrm{t}, J=10.1 \mathrm{~Hz}, 1 \mathrm{H}), 4.15(\mathrm{C}-\mathrm{H} 12 \mathrm{a}, \mathrm{t}, J=11.1 \mathrm{~Hz}, 1 \mathrm{H})$, 4.11 (D-H12a, m, 1H), 4.08 (D-H12b, m, 1H), 4.06 (B-H12, m, 2H), 3.99 (F-H12, m, 2H), 3.95 (EH12a, m, 1H), $3.87(\mathrm{C}-\mathrm{H} 12 \mathrm{~b}, \mathrm{t}, J=10.2 \mathrm{~Hz}, 1 \mathrm{H}), 3.78(\mathrm{~A}-\mathrm{H} 13 \mathrm{a}$ and C-H13a, m, 2H), 3.74 (GH12a, m, 1H), 3.71 (H-H12, m, 2H), 3.69 (G-H12b, m, 1H), 3.59 (E-H12b, m, 1H), 3.58 (E-H13a, $\mathrm{m}, 1 \mathrm{H}), 3.04(\mathrm{E}-\mathrm{H} 13 \mathrm{~b}, \mathrm{~m}, 1 \mathrm{H}), 2.59(\mathrm{~A}-\mathrm{H} 13 \mathrm{~b}, \mathrm{~m}, 1 \mathrm{H}), 2.56(\mathrm{C}-\mathrm{H} 13 \mathrm{~b}, \mathrm{~m}, 1 \mathrm{H}) .{ }^{13} \mathrm{C}$ NMR data: see Table S7). ${ }^{31} \mathrm{P}$ NMR (122 MHz, $\mathrm{H}_{2} \mathrm{O} / \mathrm{D}_{2} \mathrm{O}$ [9:1 vol/vol], 50mM NH $\left.\mathrm{mCO}_{3}\right) \delta 11.50(2 \mathrm{P}), 10.95$, 10.84, $10.81(2 \mathrm{P}), 10.69,10.59$. MALDI MS calculated for $\mathrm{C}_{92} \mathrm{H}_{83} \mathrm{~N}_{16} \mathrm{O}_{41} \mathrm{P}_{8}: 2315(\mathrm{M}+\mathrm{H})^{+}$; Found: 2317. Analytical HPLC profile: see section 3.8.7.

$\left({ }^{\mathrm{m}} \mathrm{QQ}^{4}\right)_{8}$ ammonium salt. ${ }^{1} \mathrm{H} \mathrm{NMR}\left(700 \mathrm{MHz}, \mathrm{H}_{2} \mathrm{O} / \mathrm{D}_{2} \mathrm{O}[9: 1 \mathrm{vol} / \mathrm{vol}], 50 \mathrm{mM} \mathrm{NH} \mathrm{HCO}_{3}\right.$, 'watergate' water suppression applied at $4.68 \mathrm{ppm}$ which may cause errors in the observed peak intensities in the vicinity of the suppressed peak) $\delta 11.40(\mathrm{~s}, 1 \mathrm{H}), 11.20(\mathrm{~s}, 1 \mathrm{H}), 10.54(\mathrm{~s}, 1 \mathrm{H}), 10.18$ $(\mathrm{s}, 1 \mathrm{H}), 10.16(\mathrm{~s}, 1 \mathrm{H}), 9.97(\mathrm{~s}, 1 \mathrm{H}), 9.94(\mathrm{~s}, 1 \mathrm{H}), 9.91(\mathrm{~s}, 1 \mathrm{H}), 9.87(\mathrm{~s}, 1 \mathrm{H}), 9.44-9.41(\mathrm{~m}, 2 \mathrm{H}), 9.23$ (brs, 1H), 9.13 (brs, 1H), 9.01 (brs, 1H), 8.99 (brs, 1H), 8.31 (d, J = 7.5 Hz, 1H), 7.92-7.76 (m, $10 \mathrm{H}), 7.59(\mathrm{t}, \mathrm{J}=6.8 \mathrm{~Hz}, 1 \mathrm{H}), 7.56(\mathrm{~s}, 1 \mathrm{H}), 7.44(\mathrm{t}, \mathrm{J}=6.7 \mathrm{~Hz}, 1 \mathrm{H}), 7.36(\mathrm{t}, \mathrm{J}=6.9 \mathrm{~Hz}, 1 \mathrm{H}), 7.34-$ $7.23(\mathrm{~m}), 7.15(\mathrm{~d}, \mathrm{~J}=7.8 \mathrm{~Hz}, 1 \mathrm{H}), 7.10(\mathrm{~d}, \mathrm{~J}=4.5 \mathrm{~Hz}, 1 \mathrm{H}), 7.01-6.93(\mathrm{~m}), 6.90$ (brs), 6.80 (d, J = $6.2 \mathrm{~Hz}, 1 \mathrm{H}), 6.59-6.20$ (m), 6.18 (brs), 6.13 (brs), 6.09 (s, 1H), 6.06 (s, 1H), 4.29 (s, 1H), 4.20 (s, $1 \mathrm{H}), 3.69-3.39(\mathrm{~m}), 3.04(\mathrm{~d}, \mathrm{~J}=12.4 \mathrm{~Hz}, 1 \mathrm{H}), 2.81(\mathrm{~d}, \mathrm{~J}=14.0 \mathrm{~Hz}, 1 \mathrm{H}), 2.75(\mathrm{~d}, \mathrm{~J}=14.1 \mathrm{~Hz}, 1 \mathrm{H})$, $2.66(\mathrm{~d}, \mathrm{~J}=13.3 \mathrm{~Hz}, 1 \mathrm{H}), 2.62(\mathrm{~d}, \mathrm{~J}=13.5 \mathrm{~Hz}, 1 \mathrm{H}), 2.57-2.55(\mathrm{~m}, 2 \mathrm{H}) .{ }^{31} \mathrm{P}$ NMR $(122 \mathrm{MHz}$, $\left.\mathrm{H}_{2} \mathrm{O} / \mathrm{D}_{2} \mathrm{O}[9 / 1], 50 \mathrm{mM} \mathrm{NH}_{4} \mathrm{HCO}_{3}\right) \delta 11.77,11.49,11.21,11.14(3 \mathrm{P}), 11.11(3 \mathrm{P}), 11.08,11.05$, 11.01 (2P), 11.00, 10.98, 10.90. MALDI MS calculated for $\mathrm{C}_{184} \mathrm{H}_{163} \mathrm{~N}_{32} \mathrm{O}_{81} \mathrm{P}_{16}: 4614(\mathrm{M}+\mathrm{H})^{+}$; Found: 4612. Analytical HPLC profile: see section 3.8.7.

$\left({ }^{\mathrm{m}} \mathrm{QQ}^{4}\right)_{12}$ ammonium salt. ${ }^{1} \mathrm{H} \mathrm{NMR}\left(700 \mathrm{MHz}, \mathrm{H}_{2} \mathrm{O} / \mathrm{D}_{2} \mathrm{O}[9: 1 \mathrm{vol} / \mathrm{vol}], 50 \mathrm{mM} \mathrm{NH} \mathrm{HCO}_{3}\right.$, 'watergate' water suppression applied at $4.69 \mathrm{ppm}$ which may cause errors in the observed peak intensities in the vicinity of the suppressed peak) $\delta 11.42(\mathrm{~s}, 1 \mathrm{H}), 11.16(\mathrm{~s}, 1 \mathrm{H}), 10.44(\mathrm{~s}, 1 \mathrm{H}), 10.08$ $(\mathrm{s}, 2 \mathrm{H}), 9.89(\mathrm{~s}, 1 \mathrm{H}), 9.84(\mathrm{~s}, 1 \mathrm{H}), 9.82(\mathrm{~s}, 1 \mathrm{H}), 9.77(\mathrm{~s}, 1 \mathrm{H}), 9.74(\mathrm{~s}, 1 \mathrm{H}), 9.72(\mathrm{~s}, 3 \mathrm{H}), 9.31$ (brs, $1 \mathrm{H}), 9.20$ (brs, 1H), 9.11 (brs, $1 \mathrm{H}), 9.05$ (brs, 1H), 9.00 (brs, 3H), 8.95 (brs, $1 \mathrm{H}$ ), 8.85 (brs, $1 \mathrm{H}$ ), 8.81 (brs, $1 \mathrm{H}), 8.30(\mathrm{~d}, \mathrm{~J}=7.3 \mathrm{~Hz}, 1 \mathrm{H}), 8.00(\mathrm{~d}, \mathrm{~J}=7.3 \mathrm{~Hz}, 1 \mathrm{H}), 7.89-5.95$ (m, 94H), 4.28 (brs, 
1H), 4.10 (brs, 1H), 3.89-3.27 (m), $3.06(\mathrm{~m}), 2.92(\mathrm{~d}, \mathrm{~J}=12.3 \mathrm{~Hz}, 1 \mathrm{H}), 2.65(\mathrm{~m}), 2.55-2.35(\mathrm{~m}, \mathrm{H})$. MALDI MS calculated for $\mathrm{C}_{276} \mathrm{H}_{243} \mathrm{~N}_{48} \mathrm{O}_{121} \mathrm{P}_{24}: 6909(\mathrm{M}+\mathrm{H})^{+}$; Found: 6911. Analytical HPLC profile: see section 3.8.7.

$\left({ }^{\mathrm{m}} \mathrm{QQ}^{4}\right)_{16}$ ammonium salt. ${ }^{1} \mathrm{H}$ NMR $\left(700 \mathrm{MHz}, \mathrm{H}_{2} \mathrm{O} / \mathrm{D}_{2} \mathrm{O}[9: 1 \mathrm{vol} / \mathrm{vol}], 50 \mathrm{mM} \mathrm{NH} \mathrm{HCO}_{3}\right.$, 'watergate' water suppression applied at $4.69 \mathrm{ppm}$ which may cause errors in the observed peak intensities in the vicinity of the suppressed peak) $\delta 11.43(\mathrm{~s}, 1 \mathrm{H}), 11.14(\mathrm{~s}, 1 \mathrm{H}), 10.41(\mathrm{~s}, 1 \mathrm{H}), 10.05$ $(\mathrm{s}, 1 \mathrm{H}), 10.02(\mathrm{~s}, 1 \mathrm{H}), 9.86(\mathrm{~s}, 1 \mathrm{H}), 9.80(\mathrm{~s}, 1 \mathrm{H}), 9.78(\mathrm{~s}, 1 \mathrm{H}), 9.72(\mathrm{~s}, 1 \mathrm{H}), 9.69-9.61(\mathrm{~m}, 8 \mathrm{H}), 9.24$ $(\mathrm{s}, 1 \mathrm{H}), 9.10(\mathrm{~s}, 1 \mathrm{H}), 9.04(\mathrm{~s}, 1 \mathrm{H}), 8.94-8.95(\mathrm{~m}, 8 \mathrm{H}), 8.77(\mathrm{~s}, 1 \mathrm{H}), 8.73(\mathrm{~s}, 1 \mathrm{H}), 8.28(\mathrm{~d}, J=7.0$ $\mathrm{Hz}, 1 \mathrm{H}), 8.04(\mathrm{~d}, J=6.9 \mathrm{~Hz}, 1 \mathrm{H}), 7.90-5.89(\mathrm{~m}, 126 \mathrm{H}), 4.26(\mathrm{~s}, 1 \mathrm{H}), 4.05(\mathrm{~s}, 1 \mathrm{H}), 3.85-3.22(\mathrm{~m}$, $12 \mathrm{H}), 2.87(\mathrm{~d}, J=7.1 \mathrm{~Hz}, 1 \mathrm{H}), 2.63-2.28(\mathrm{~m})$. MALDI MS calculated for $\mathrm{C}_{368} \mathrm{H}_{323} \mathrm{~N}_{64} \mathrm{O}_{161} \mathrm{P}_{32}$ : 9207.0 $(\mathrm{M}+\mathrm{H})^{+}$; Found: 9211.6. Analytical HPLC profile: see section 3.8.7.

$\left({ }^{\mathrm{m}} \mathrm{QQ}^{5}\right)_{4}$ ammonium salt. ${ }^{1} \mathrm{H}$ NMR $\left(300 \mathrm{MHz}, \mathrm{H}_{2} \mathrm{O} / \mathrm{D}_{2} \mathrm{O}[9: 1 \mathrm{vol} / \mathrm{vol}], 50 \mathrm{mM} \mathrm{NH} \mathrm{HCO}_{3}\right.$, 'watergate' water suppression applied at $4.71 \mathrm{ppm}$ which may cause errors in the observed peak intensities in the vicinity of the suppressed peak) $\delta 11.54(\mathrm{~s}, 1 \mathrm{H}), 10.93(\mathrm{brs}, 1 \mathrm{H}), 10.71(\mathrm{~s}, 1 \mathrm{H})$, 10.24 (s, 1H), 9.94 (brs, 1H), 9.72 (d, J = $10.3 \mathrm{~Hz}, 1 \mathrm{H}), 9.30$ (d, J = 8.0 Hz, 1H), 8.39 (d, J = 8.8 $\mathrm{Hz}, 1 \mathrm{H}), 8.03-7.86(\mathrm{~m}, 5 \mathrm{H}), 7.73-6.94(\mathrm{~m}, 20 \mathrm{H}), 6.80(\mathrm{~d}, \mathrm{~J}=6.9 \mathrm{~Hz}, 1 \mathrm{H}), 6.53-6.44(\mathrm{~m}, 3 \mathrm{H}), 6.34$ (s, 1H), $6.32(\mathrm{~s}, 1 \mathrm{H}), 5.21$ (brs, 1H), $4.25(\mathrm{~s}, 1 \mathrm{H}), 4.14-3.53(\mathrm{~m}), 3.17-2.37(\mathrm{~m}), 1.56(\mathrm{~m}) .{ }^{31} \mathrm{P}$ NMR $\left(122 \mathrm{MHz}, \mathrm{H}_{2} \mathrm{O} / \mathrm{D}_{2} \mathrm{O}\right.$ [9:1 vol/vol], $\left.50 \mathrm{mM} \mathrm{NH} \mathrm{HCO}_{3}\right) \delta 23.59,23.18,23.04,22.98,11.29,10.95$, 10.92, 10.78. MALDI MS calculated for $\mathrm{C}_{96} \mathrm{H}_{91} \mathrm{~N}_{16} \mathrm{O}_{37} \mathrm{P}_{8}: 2308(\mathrm{M}+\mathrm{H})^{+}$; Found: 2308. Analytical HPLC profile: see section 3.8.7.

$\left({ }^{\mathrm{m}} \mathrm{QQ}^{5}\right)_{8}$ ammonium salt. ${ }^{1} \mathrm{H} \mathrm{NMR}\left(300 \mathrm{MHz}, \mathrm{H}_{2} \mathrm{O} / \mathrm{D}_{2} \mathrm{O}\right.$ [9:1 vol/vol], $50 \mathrm{mM} \mathrm{NH} 4 \mathrm{HCO}_{3}$, 'watergate' water suppression applied at $4.71 \mathrm{ppm}$ which may cause errors in the observed peak intensities in the vicinity of the suppressed peak) $\delta 11.49(\mathrm{~s}, 1 \mathrm{H}), 11.16(\mathrm{~s}, 1 \mathrm{H}), 10.60$ (s, 1H), 10.19 (s, 2H), $10.02(\mathrm{~s}, 2 \mathrm{H}), 9.97(\mathrm{~s}, 1 \mathrm{H}), 9.95(\mathrm{~s}, 1 \mathrm{H}), 9.57(\mathrm{~d}, J=10.5 \mathrm{~Hz}, 1 \mathrm{H})$, $9.47(\mathrm{~d}, J=6.3 \mathrm{~Hz}, 1 \mathrm{H}), 9.25(\mathrm{~d}, J=5.9 \mathrm{~Hz}, 1 \mathrm{H}), 9.14(\mathrm{~d}, J=8.5 \mathrm{~Hz}, 1 \mathrm{H}), 9.03(\mathrm{~d}, J=9.3$ $\mathrm{Hz}, 1 \mathrm{H}), 9.00(\mathrm{~d}, J=10.6 \mathrm{~Hz}, 2 \mathrm{H}), 8.37(\mathrm{~d}, J=8.7 \mathrm{~Hz}, 1 \mathrm{H}), 7.97-6.14(\mathrm{~m}, 63 \mathrm{H}), 4.06-$ $3.45(\mathrm{~m}), 3.03-2.10(\mathrm{~m}), 1.60-1.12(\mathrm{~m})$. ESI MS calculated for $\mathrm{C}_{192} \mathrm{H}_{175} \mathrm{~N}_{32} \mathrm{O}_{73} \mathrm{P}_{16}: 1531$ (M$3 \mathrm{H})^{3-}$; Found: 1531; calculated for $\mathrm{C}_{192} \mathrm{H}_{172} \mathrm{~N}_{32} \mathrm{O}_{73} \mathrm{P}_{16}: 765(\mathrm{M}-6 \mathrm{H})^{6-}$; Found: 765. Analytical HPLC profile: see section 3.8.7.

\subsubsection{Synthesis of oligomer-nucleotide conjugate}

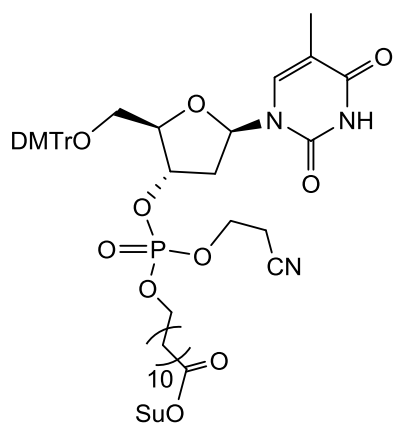

Synthesis of S47: 5'-Dimethoxytrityl-3'-deoxythymidine 2'-[(2-cyanoethyl)-( $N, N$-diisopropyl)]phosphoramidite (S46, $272 \mathrm{mg}, 0.36 \mathrm{mmol}, 1.5$ equiv., from M. C. de Kining et al. Org. Process Res. \& Develop. 10, 1238-1245 (2006)) and N-hydroxysuccinidimyl 12-hydroxy-dodecanoate (76 $\mathrm{mg}, 1$ equiv.) were introduced in a dry flask under $\mathrm{N}_{2}$. To this was added $2 \mathrm{~mL}$ of acetonitrile (DNA synthesis grade) and the solution was evaporated under reduced pressure on a vacuum line. The process was repeated once. Then, a solution of tetrazole in acetonitrile $(2.45 \mathrm{~mL}, 0.45 \mathrm{M})$ was added and the mixture was stirred at room temperature for 40 min under $\mathrm{N}_{2}$. Water $(87 \mu \mathrm{L}, 20$ equiv.) was then added and the mixture stirred for $2 \mathrm{~min}$ at room temperature. A solution of $\mathrm{I}_{2}(76$ 
$\mathrm{mg}, 0.3 \mathrm{mmol}, 3$ equiv.) in $1.5 \mathrm{~mL}$ of THF/pyridine ( $3: 1 \mathrm{vol} / \mathrm{vol})$ was added dropwise and stirring was continued for $5 \mathrm{~min}$. The reaction mixture was diluted with EtOAc $(5 \mathrm{~mL})$ and the organic phase was separated and washed with $1 \mathrm{M}$ aqueous $\mathrm{Na}_{2} \mathrm{~S}_{2} \mathrm{O}_{3}(3 \mathrm{~mL}), 10 \%$ wt/vol aqueous $\mathrm{KHSO}_{4}$ $(2 \times 3 \mathrm{~mL}), 10 \% \mathrm{wt} / \mathrm{vol}$ aqueous $\mathrm{NaHCO}_{3}(1 \times 3 \mathrm{~mL})$ and half-saturated brine $(1 \times 3 \mathrm{~mL})$. The aqueous phases were combined and back extracted with $3 \mathrm{~mL}$ EtOAc and the combined organic phases were dried over $\mathrm{Na}_{2} \mathrm{SO}_{4}$, filtered and evaporated under reduced pressure. Purification of the residue by column chromatography (EtOAc) yielded a colourless sticky paste ( $225 \mathrm{mg}, 92 \%$, yield). ${ }^{1} \mathrm{H} \mathrm{NMR}\left(300 \mathrm{MHz}, \mathrm{CDCl}_{3}\right) \delta 8.77(\mathrm{~s}, 1 \mathrm{H}), 7.58-7.57(\mathrm{~m}, 1 \mathrm{H}), 7.41-7.26(\mathrm{~m}, 9 \mathrm{H}), 6.89-6.84(\mathrm{~m}$, $4 \mathrm{H}), 6.46(\mathrm{dd}, J=8.7,5.5 \mathrm{~Hz}, 1 \mathrm{H}), 5.20-5.13(\mathrm{~m}, 1 \mathrm{H}), 4.33-4.00(\mathrm{~m}, 5 \mathrm{H}), 3.82(\mathrm{~s}, 6 \mathrm{H}), 3.59-$ $3.50(\mathrm{~m}, 1 \mathrm{H}), 3.45-3.38(\mathrm{~m}, 1 \mathrm{H}), 2.85(\mathrm{~s}, 4 \mathrm{H}), 2.77(\mathrm{dd}, J=9.3,3.2 \mathrm{~Hz}, 1 \mathrm{H}), 2.72-2.58(\mathrm{~m}, 4 \mathrm{H})$, $2.51-2.39(\mathrm{~m}, 1 \mathrm{H}), 1.82-1.61(\mathrm{~m}, 6 \mathrm{H}), 1.47-1.24(\mathrm{~m}, 15 \mathrm{H}) .{ }^{13} \mathrm{C} \mathrm{NMR}\left(75 \mathrm{MHz}, \mathrm{CDCl}_{3}\right) \delta$ 169.22 , 168.65, 163.46, 158.76, 150.27, 150.21, 143.98, 135.15, 135.03, 135.01, 134.98, 130.06, $128.09,128.00,127.23,116.32,116.26,116.17,113.28,111.59,111.56,87.19,84.47,84.39,84.20$, $78.93,78.86,78.80,78.73,68.96,68.88,68.79,63.23,63.18,62.02,61.95,61.92,61.85,55.22$, $39.00,30.86,30.12,30.03,29.62,29.29,29.17,28.94,28.65,25.54,25.25,24.48,19.67,19.60$, 19.57, 19.50, 11.61, 1.81. ${ }^{31} \mathrm{P}$ NMR $\left(\mathrm{CDCl}_{3}, 122 \mathrm{MHz}\right) \delta:-2.46,-2.49$; HRMS ESI MS calculated for $\mathrm{C}_{50} \mathrm{H}_{62} \mathrm{~N}_{4} \mathrm{O}_{14} \mathrm{P}: 973.3995$. Found: $973.3994(\mathrm{M}+\mathrm{H})^{+}$.

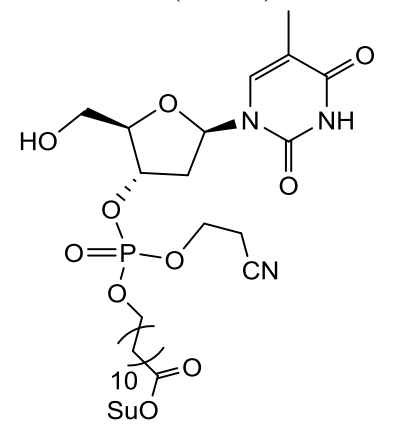

Synthesis of S48: Compound S47 (30 mg, $0.03 \mathrm{mmol}$ ) was dissolved in a $3 \% \mathrm{vol} / \mathrm{vol}$ trichloroacetic acid solution in DCM (2 mL, 12 equiv.) and stirred at room temperature for $2 \mathrm{~min}$. The solution was diluted with dichloromethane and washed with water (x 3), dried over $\mathrm{Na}_{2} \mathrm{SO}_{4}$, filtered, and evaporated. Purification by column chromatography (DCM/ MeOH 97: 3) yielded the product as a colourless sticky paste in almost quantitative yield. ${ }^{1} \mathrm{H} N \mathrm{NR}\left(\mathrm{CDCl}_{3}, 300 \mathrm{MHz}\right) \delta 8.81$ $(\mathrm{s}, 1 \mathrm{H}), 7.46(\mathrm{~d}, J=1.0 \mathrm{~Hz}, 1 \mathrm{H}), 6.23-6.18(\mathrm{t}, J=6.20 \mathrm{~Hz}, 1 \mathrm{H}), 5.18-5.13(\mathrm{~m}, 1 \mathrm{H}), 4.31-4.21(\mathrm{~m}$, $3 \mathrm{H}), 4.14-4.07(\mathrm{q}, J=6.7 \mathrm{~Hz}, 2 \mathrm{H}), 3.06(\mathrm{bs}, 2 \mathrm{H}), 2.83(\mathrm{~s}, 3 \mathrm{H}), 2.81-2.77(\mathrm{~m}, 2 \mathrm{H}), 2.62-2.57(\mathrm{t}, J=$ $7.45 \mathrm{~Hz}, 2 \mathrm{H}), 2.53-2.47(\mathrm{~m}, 2 \mathrm{H}), 1.76-1.68 \mathrm{~m}, 6 \mathrm{H}), 1.39-1.25(\mathrm{~m}, 15 \mathrm{H}) .{ }^{13} \mathrm{C} \mathrm{NMR}\left(\mathrm{CDCl}_{3}, 75\right.$ MHz) $\delta 169.3,168.7,163.6,150.34,150.31,136.45,116.5,111.3,86.2,85.6,85.5,69.1,69.0,62.1$, $62.0,38.5,38.4,38.3,30.9,30.2,30.1,29.28,29.17,29.0,28.7,25.6,25.3,24.5,19.8,19.7,12.5$. ${ }^{31} \mathrm{P}$ NMR $\left(\mathrm{CDCl}_{3}, 121 \mathrm{MHz}\right) \delta:-2.21,-2.23$. HRMS ESI MS calculated for $\mathrm{C}_{29} \mathrm{H}_{44} \mathrm{~N}_{4} \mathrm{O}_{12} \mathrm{P}$ : 671.2688. Found: $671.2715(\mathrm{M}+\mathrm{H})^{+}$.

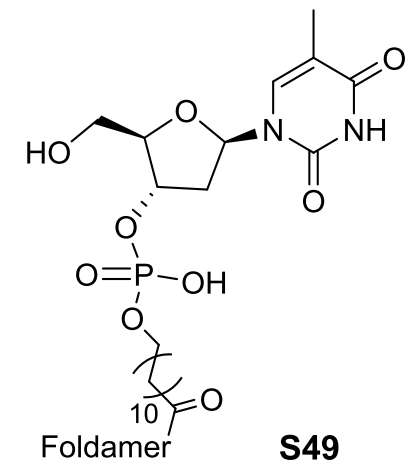


Conjugation with foldamer: $\left({ }^{\mathrm{m}} \mathrm{QQ}^{4}\right)_{8}(1.3 \mathrm{mg}, 1$ equiv.) was stirred with compound $\mathbf{S 4 8}(0.8 \mathrm{mg}$, 5 equiv.) in a $300 \mu \mathrm{L}$ of $1: 1$ mixture of DMF and $12.5 \mathrm{mM}$ aqueous triethylammonium acetate ( $\mathrm{pH}$ : 8.7) for 2 days. The reaction was monitored by RP-HPLC and the crude was purified by RP-HPLC using basic phase conditions as described in the general methods to yield S49. MALDI MS calculated for $\mathrm{C}_{206} \mathrm{H}_{198} \mathrm{~N}_{34} \mathrm{O}_{90} \mathrm{P}_{17}: 5116$. Found: $5116(\mathrm{M}+\mathrm{H})^{+}$. Analytical HPLC profile: see section 3.8.7.

\subsubsection{Synthesis of biotin-oligomer conjugates}

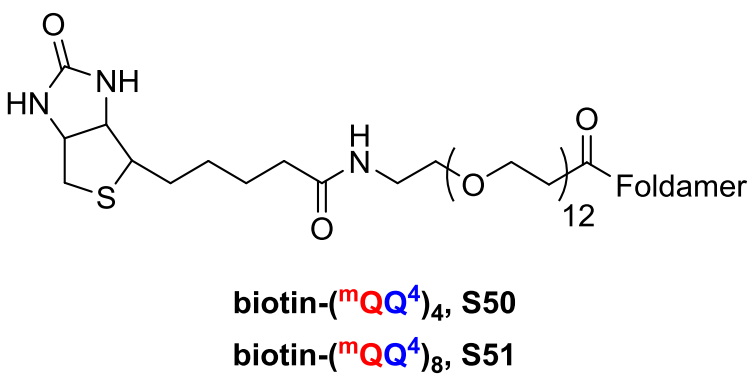

Synthesis of S50: Unprotected $\left({ }^{\mathrm{m}} \mathrm{QQ}^{4}\right)_{4}(2.5 \mathrm{mg}, 1$ equiv.) was stirred with commercially available biotin-(PEG) ${ }_{12}$-OSu reagent $(2.2 \mathrm{mg}, 3$ equiv.) in a $180 \mu \mathrm{L}$ of $1: 1.5$ (vol/vol) mixture of water and DMF for one day. The reaction was monitored by RP-HPLC and the crude was purified by RPHPLC using basic phase conditions as described in the general methods to yield $\mathbf{S 5 0}$ in $55 \%$ yield $(1.4 \mathrm{mg})$. This compound was stored at $-18^{\circ} \mathrm{C}$ and protected from air and light to limit biotin oxidation. ESI MS calculated for $\mathrm{C}_{129} \mathrm{H}_{149} \mathrm{~N}_{19} \mathrm{O}_{56} \mathrm{P}_{8} \mathrm{~S}$ : 3139.7. Found: $1045.9(\mathrm{M}-3 \mathrm{H})^{3-}$. Analytical HPLC profile: see section 3.8.7.

Synthesis of S51: Unprotected $\left({ }^{\mathrm{m}} \mathrm{QQ}^{4}\right)_{8}(5.3 \mathrm{mg}, 1$ equiv.) was stirred with commercially available biotin-(PEG) ${ }_{12}$-OSu reagent $(2.3 \mathrm{mg}, 3$ equiv.) in a $360 \mu \mathrm{L}$ of $1: 3$ mixture (vol/vol) of water and DMF for one day. The reaction was monitored by RP-HPLC and the crude was purified by RPHPLC using basic phase conditions as described in the general methods to yield pure biotin$\left({ }^{\mathrm{m}} \mathrm{QQ}^{4}\right)_{8} \mathrm{S51}$ in $53 \%$ yield $(2.4 \mathrm{mg})$. This compound was stored at $-18^{\circ} \mathrm{C}$ and protected from air and light to limit biotin oxidation. HRMS ESI MS calculated for $\mathrm{C}_{221} \mathrm{H}_{229} \mathrm{~N}_{35} \mathrm{O}_{96} \mathrm{P}_{16} \mathrm{~S}$ : 5439.0522 . Found: $1358.4920(\mathrm{M}-4 \mathrm{H})^{4-}$. Analytical HPLC profile: see section 3.8.7.

\subsubsection{Synthesis of model phosphonate monomers}<smiles>CCCCOP(=O)(COc1ccc(C#N)cc1)OCCC</smiles> 
Synthesis of S52: 4-Hydroxybenzonitrile (400 mg, $3.36 \mathrm{mmol}$ ) was placed in a flask equipped with a stirring bar which was evacuated and backfilled with nitrogen. Dry THF $(5 \mathrm{~mL})$ was added followed by $\mathrm{PPh}_{3}(1.146 \mathrm{~g}, 4.37 \mathrm{mmol}, 1.3$ equiv.) and di-tert-butyl hydroxymethyl phosphonate (978 mg, $4.37 \mathrm{mmol}, 1.3$ equiv.). The mixture was stirred at $0{ }^{\circ} \mathrm{C}$ under nitrogen and DIAD (0.9 $\mathrm{mL}, 4.37 \mathrm{mmol}, 1.3$ equiv.) was added dropwise over $40 \mathrm{~min}$ at $0{ }^{\circ} \mathrm{C}$. The reaction was continued for $40 \mathrm{~min}$ at $0{ }^{\circ} \mathrm{C}$, then at room temperature for $1 \mathrm{~h}$, and at $50^{\circ} \mathrm{C}$ for $16 \mathrm{~h}$. The mixture was cooled to room temperature. Solvents were removed under reduced pressure and purification of the viscous oil by silica gel chromatography eluting with cyclohexane:EtOAc 40:60 afforded compound S52 as a white solid $(540 \mathrm{mg}, 50 \%) .{ }^{1} \mathrm{H}$ NMR $\left(300 \mathrm{MHz}, \mathrm{CDCl}_{3}\right) \delta 7.59(\mathrm{~d}, J=9.0 \mathrm{~Hz}, 2 \mathrm{H}), 7.02(\mathrm{~d}, J$ $=9.0 \mathrm{~Hz}, 2 \mathrm{H}), 4.17(\mathrm{~d}, J=12.0 \mathrm{~Hz}, 2 \mathrm{H}), 1.53(\mathrm{~s}, 18 \mathrm{H}) .{ }^{13} \mathrm{C} \mathrm{NMR}\left(75 \mathrm{MHz}, \mathrm{CDCl}_{3}\right) \delta 162.1(\mathrm{~d}, J$ $=12.0 \mathrm{~Hz}, 1 \mathrm{C}), 134.0,119.1,115.6,104.9,83.9,83.8,64.8(\mathrm{~d}, J=174.7 \mathrm{~Hz}, 1 \mathrm{C}), 30.6,30.5 .{ }^{31} \mathrm{P}$ NMR (122 MHz, $\left.\mathrm{CDCl}_{3}\right) \delta$ 9.96. HRMS ESI MS calculated for $\mathrm{C}_{16} \mathrm{H}_{24} \mathrm{NO}_{4} \mathrm{P}: 325.1443$; Found: $348.1333(\mathrm{M}+\mathrm{Na})^{+}$.

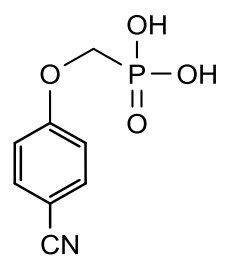

Synthesis of S53: Compound $\mathbf{S 5 2}(400 \mathrm{mg}, 1.23 \mathrm{mmol})$ was dissolved in a TFA/DCM/TIPS mixture (50:48:2 vol/vol/vol, $8 \mathrm{~mL}$ ) and stirred for $3 \mathrm{~h}$ at room temperature. Completion of the reaction was confirmed by TLC. The solvents were removed under reduced pressure and the excess of TFA was co-evaporated with toluene (x4). Precipitation from cold $\mathrm{Et}_{2} \mathrm{O}$ yielded $\mathbf{S 5 3}$ as a white solid (260 mg, quantitative). ${ }^{1} \mathrm{H}$ NMR (300 MHz, DMSO-d 6$) \delta 7.77(\mathrm{~d}, J=9.0 \mathrm{~Hz}, 2 \mathrm{H}), 7.17(\mathrm{~d}, J$ $=9.0 \mathrm{~Hz}, 2 \mathrm{H}), 4.21(\mathrm{~d}, J=12.0 \mathrm{~Hz}, 2 \mathrm{H}) .{ }^{13} \mathrm{C} \mathrm{NMR}\left(75 \mathrm{MHz}, \mathrm{CDCl}_{3}\right) \delta 162.2(\mathrm{~d}, J=12.0 \mathrm{~Hz}, 1 \mathrm{C})$, 134.1, 119.0, 115.6, 103.3, 63.9 (d, $J=160.5 \mathrm{~Hz}, 1 \mathrm{C}) .{ }^{31} \mathrm{P} \mathrm{NMR}\left(122 \mathrm{MHz}, \mathrm{CDCl}_{3}\right) \delta 13.97$. HRMS ESI MS calculated for $\mathrm{C}_{8} \mathrm{H}_{8} \mathrm{NO}_{4} \mathrm{P}: 213.0191$; Found: 212.0107 (M-H)- 


\subsubsection{HPLC traces, ${ }^{1} \mathrm{H}$ NMR and ${ }^{13} \mathrm{C}$ NMR spectra of purified new synthetic compounds}

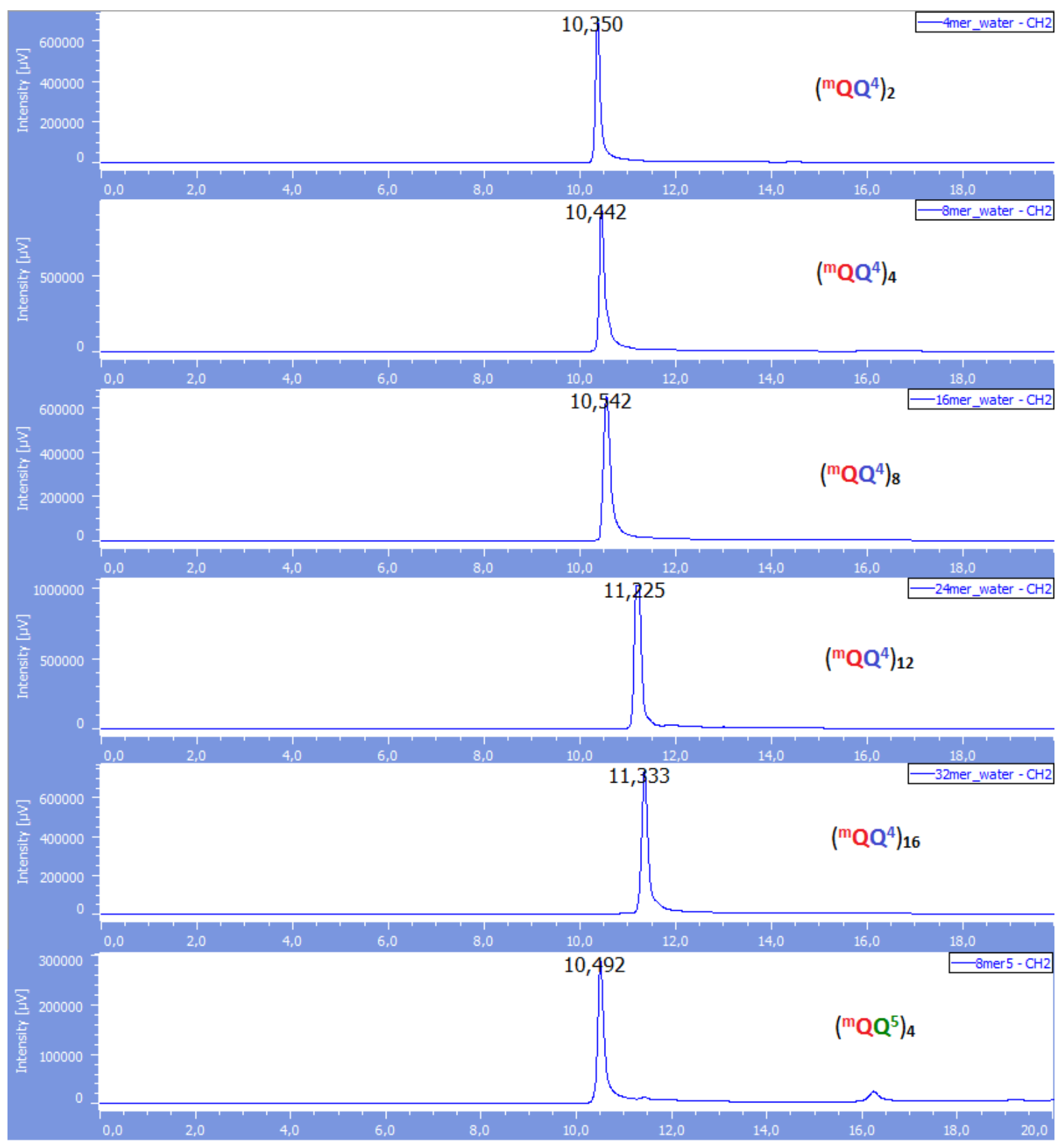

HPLC traces of deprotected foldamers $\left({ }^{\mathrm{m}} \mathrm{QQ}^{4}\right)_{2},\left({ }^{\mathrm{m}} \mathrm{QQ}^{4}\right)_{4},\left({ }^{\mathrm{m}} \mathrm{QQ}^{4}\right)_{\mathbf{8}},\left({ }^{\mathrm{m}} \mathrm{QQ}^{4}\right)_{12},\left({ }^{\mathrm{m}} \mathrm{QQ}^{4}\right)_{16},\left({ }^{\mathrm{m}} \mathrm{QQ}^{5}\right)_{4}$. Separations conditions: Varian Pursuit C18 column ( $4.6 \times 250 \mathrm{~mm}, 5 \mu \mathrm{m})$; UV detection at $\lambda=240$ $\mathrm{nm}$; gradient of eluents "A" and "B", where "A" was $12.5 \mathrm{mM}$ triethylammonium acetate, $\mathrm{pH} 8.7$, in water, $\mathrm{pH} 8.7$ and " $\mathrm{B}$ " was $12.5 \mathrm{mM}$ triethylammonium acetate, $\mathrm{pH} 8.7$, in water:acetonitrile (3:1); gradient program (0 min) 100\% “A", $0 \%$ " B" $\rightarrow$ (2.1 min) 100\% "A", $0 \%$ "B" $\rightarrow$ (15 min) $80 \%$ "A", 20\% "B". 


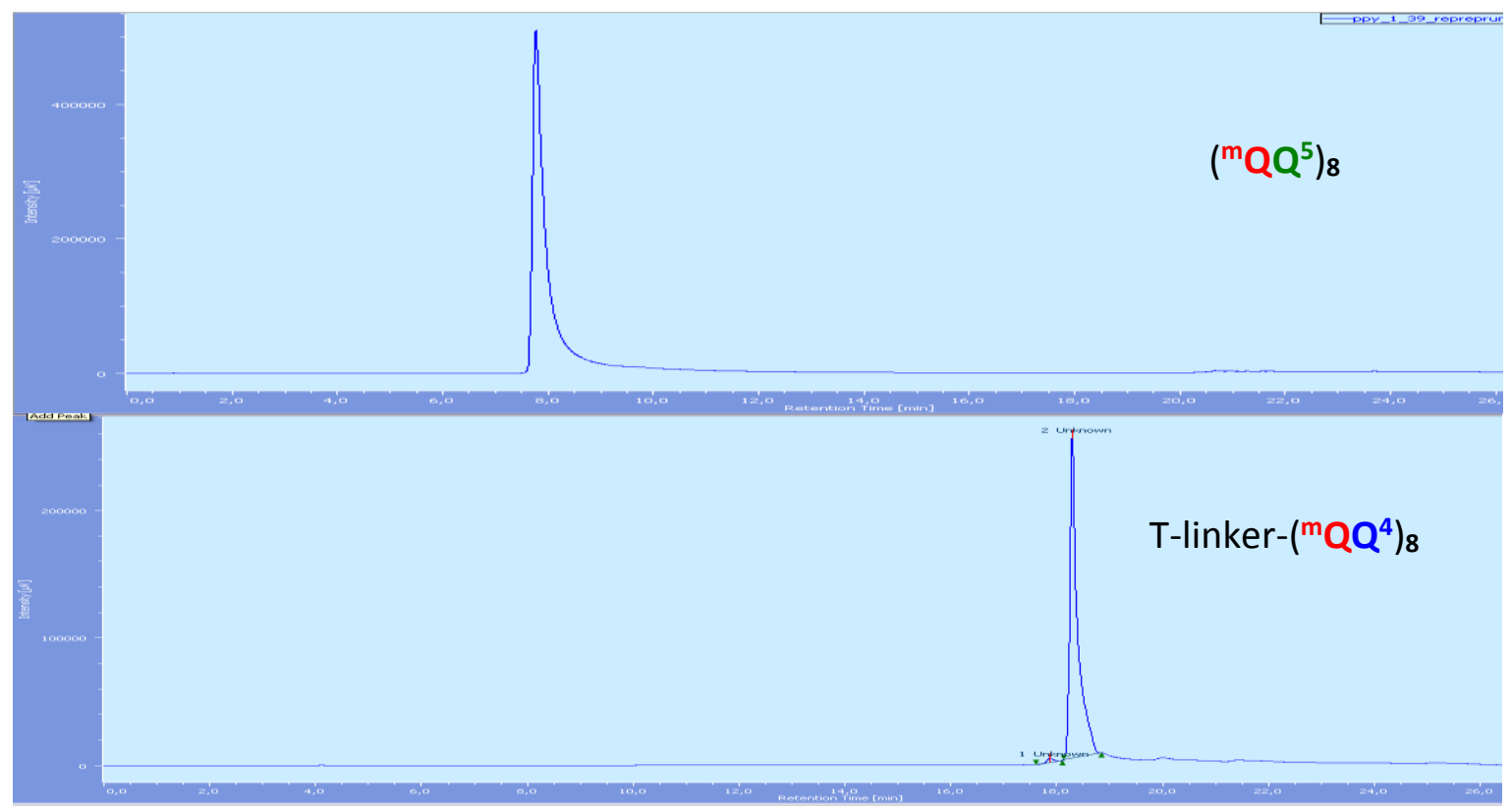

HPLC chromatogram of purified deprotected $\left({ }^{\mathrm{m}} \mathrm{QQ}^{5}\right)_{8}$ (gradient program $(0 \mathrm{~min}) 100 \%$ "A", $0 \%$ " $\mathrm{B}$ " $\rightarrow(20 \mathrm{~min}) 75 \%$ "A", 25\% "B"; $\left.t_{\mathrm{R}}: 7.76 \mathrm{~min}\right)$ and of purified nucleotide-( $\left.{ }^{\mathrm{m}} \mathrm{QQ}{ }^{4}\right)_{8}$ conjugate (S49) (gradient program (0 min) 100\% “A”, 0\%" B" $\rightarrow$ (15 min) 80\% “A”, 20\% "B"; $t_{\mathrm{R}}: 18.28$ $\min )$.

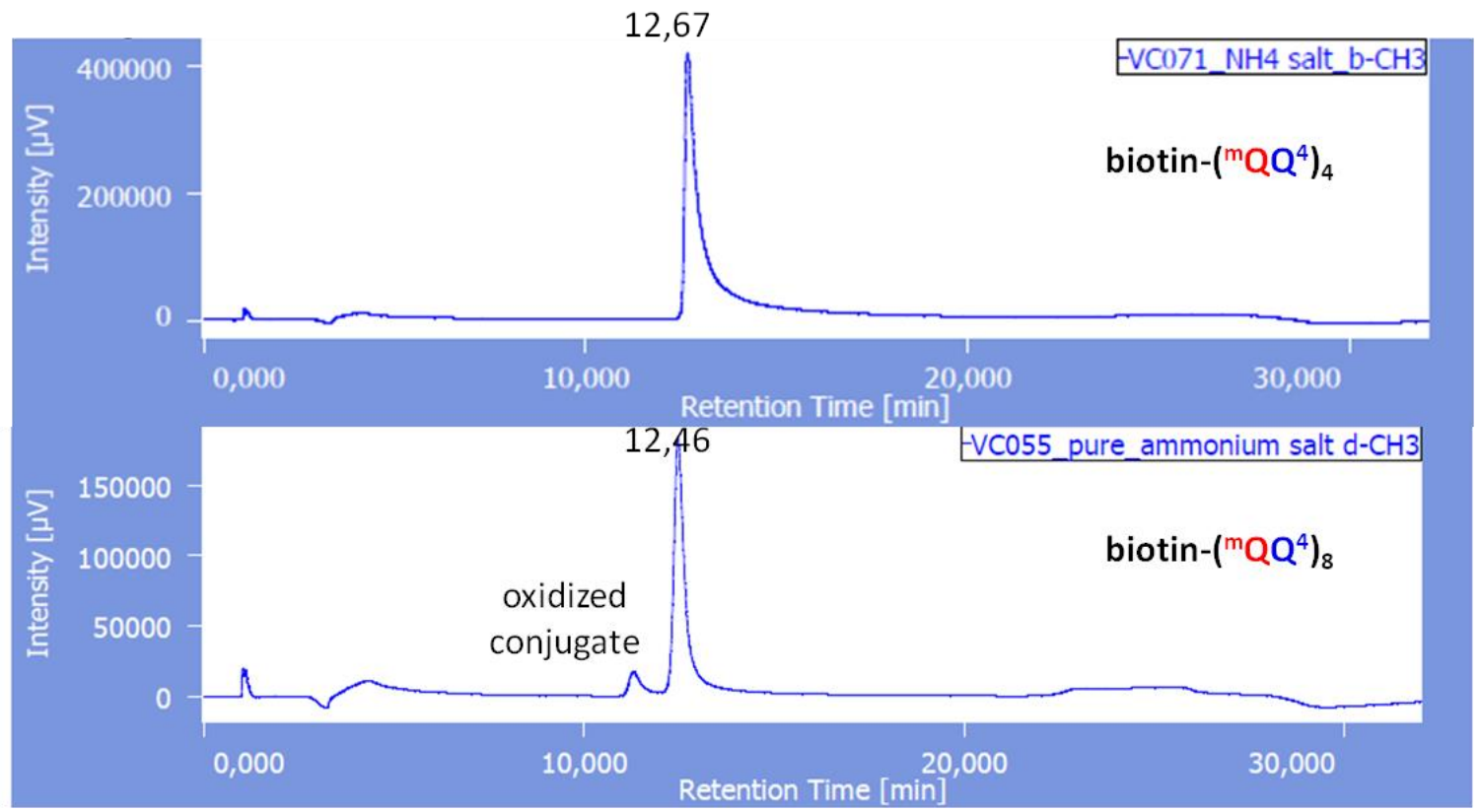

HPLC traces of compounds S50, biotin- $\left({ }^{\mathrm{m}} \mathbf{Q} \mathbf{Q}^{4}\right)_{4}$ and $\mathbf{S 5 1}$, biotin- $\left({ }^{\mathrm{m}} \mathbf{Q} \mathbf{Q}^{4}\right)_{8}$ after exchange of triethylammonium to ammonium cations. Elution conditions: Nucleodur C18 HTec column $(4 \mathrm{x}$ $100 \mathrm{~mm}, 5 \mu \mathrm{m}$ ); UV detection at $\lambda=300 \mathrm{~nm}$; gradient of eluents "A" and "B", where "A" was 12.5 $\mathrm{mM}$ triethylammonium acetate, $\mathrm{pH} 8.7$, in water, and "B" was $12.5 \mathrm{mM}$ triethylammonium acetate, $\mathrm{pH} 8.7$, in water:acetonitrile (3:1); gradient program (0 min) $100 \%$ "A", $0 \%$ " B" $\rightarrow(2.1 \mathrm{~min})$ $100 \%$ "A", 0\% "B" $\rightarrow$ (15 min) 80\% “A”, 20\% "B". 


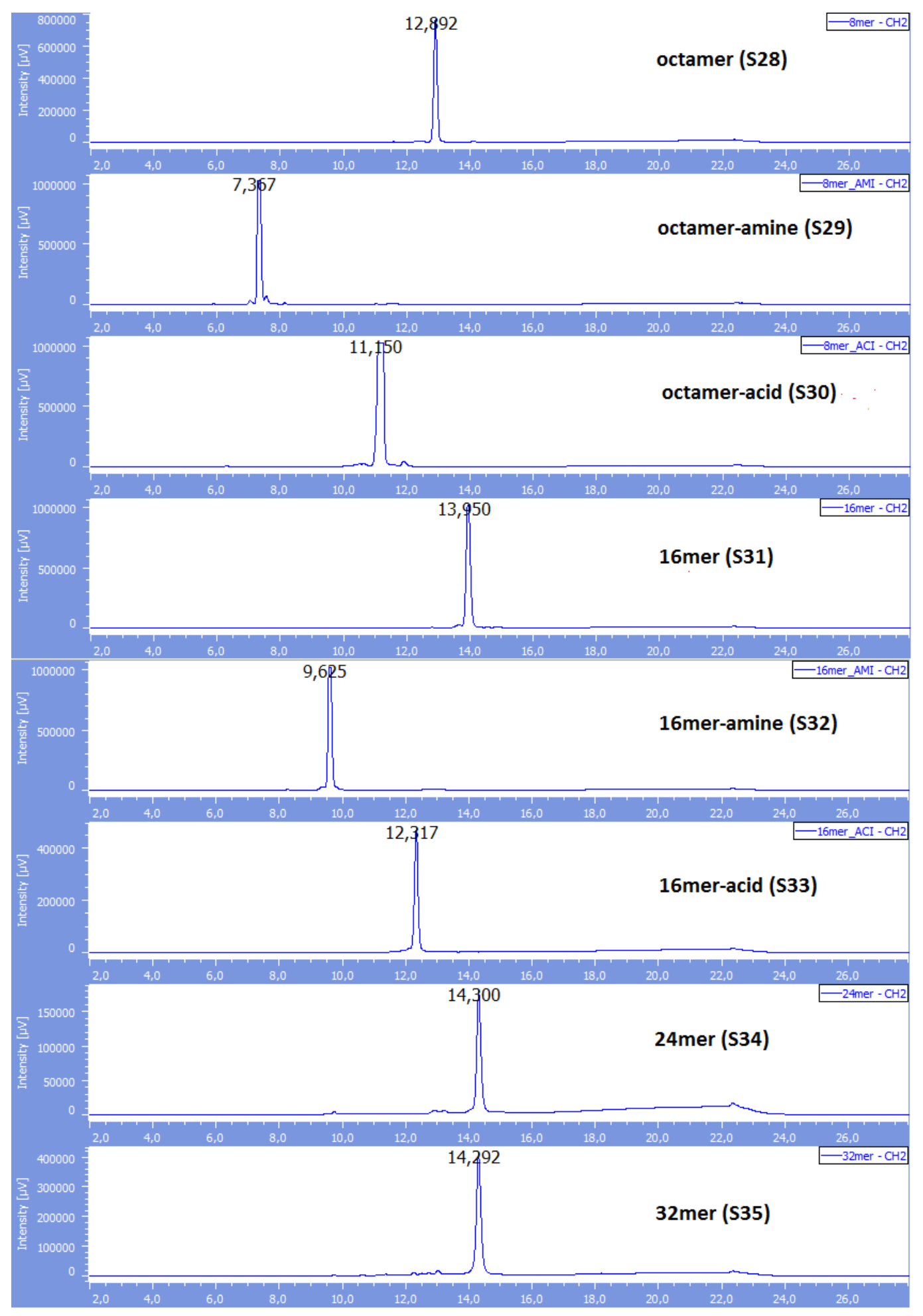

HPLC traces of compounds S28-S35. Elution conditions: Nucleodur C8 column (4.6 x $150 \mathrm{~mm}, 5$ $\mu \mathrm{m})$; UV detection at $\lambda=254 \mathrm{~nm}$; gradient of eluents "A" and "B", where "A" was $0.1 \%(\mathrm{vol} / \mathrm{vol})$ TFA in water and "B" was $0.1 \%$ TFA in acetonitrile; gradient program (0 min) $70 \%$ " $\mathrm{A}$ ", $30 \%$ " $\mathrm{B}$ " $\rightarrow$ (2.1 min) $70 \%$ “A”, 30\% "B" $\rightarrow$ (20 min) 30\% “A”, 70\% "B". 


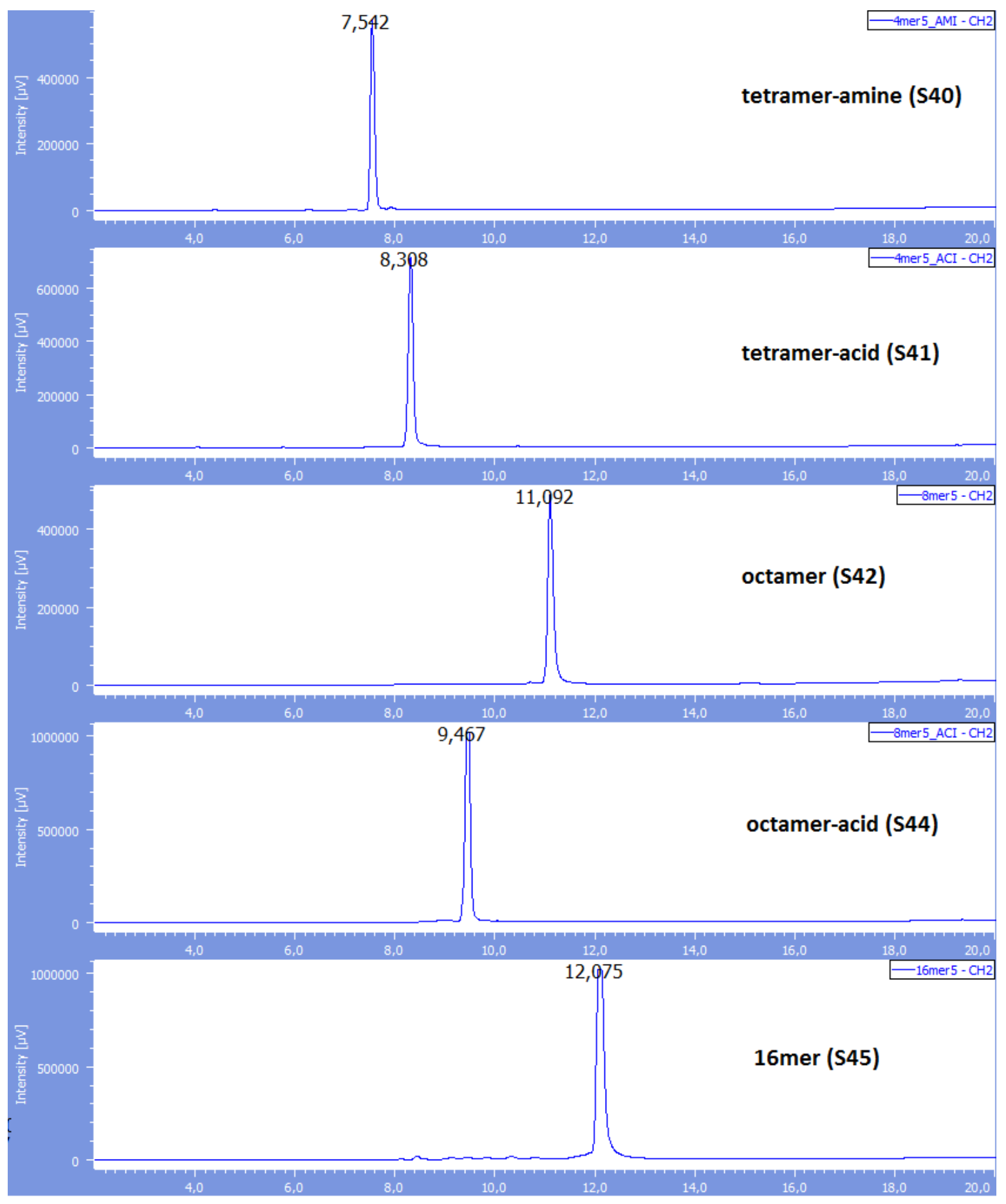

HPLC traces of compounds S40-S42, $\mathbf{S 4 4}$ and $\mathbf{S 4 5}$. Separations conditions are the same as for compounds S28-S35. 


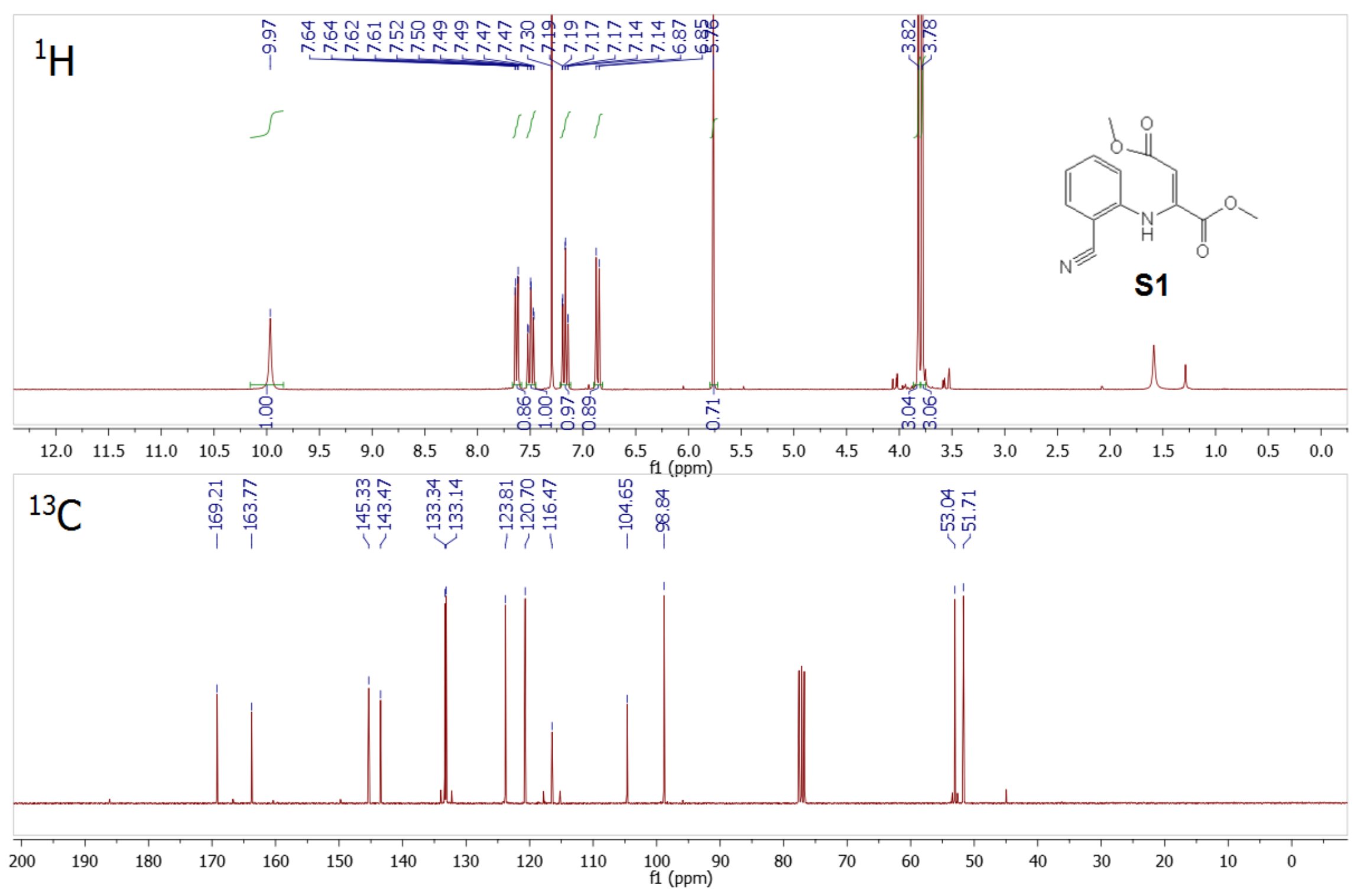



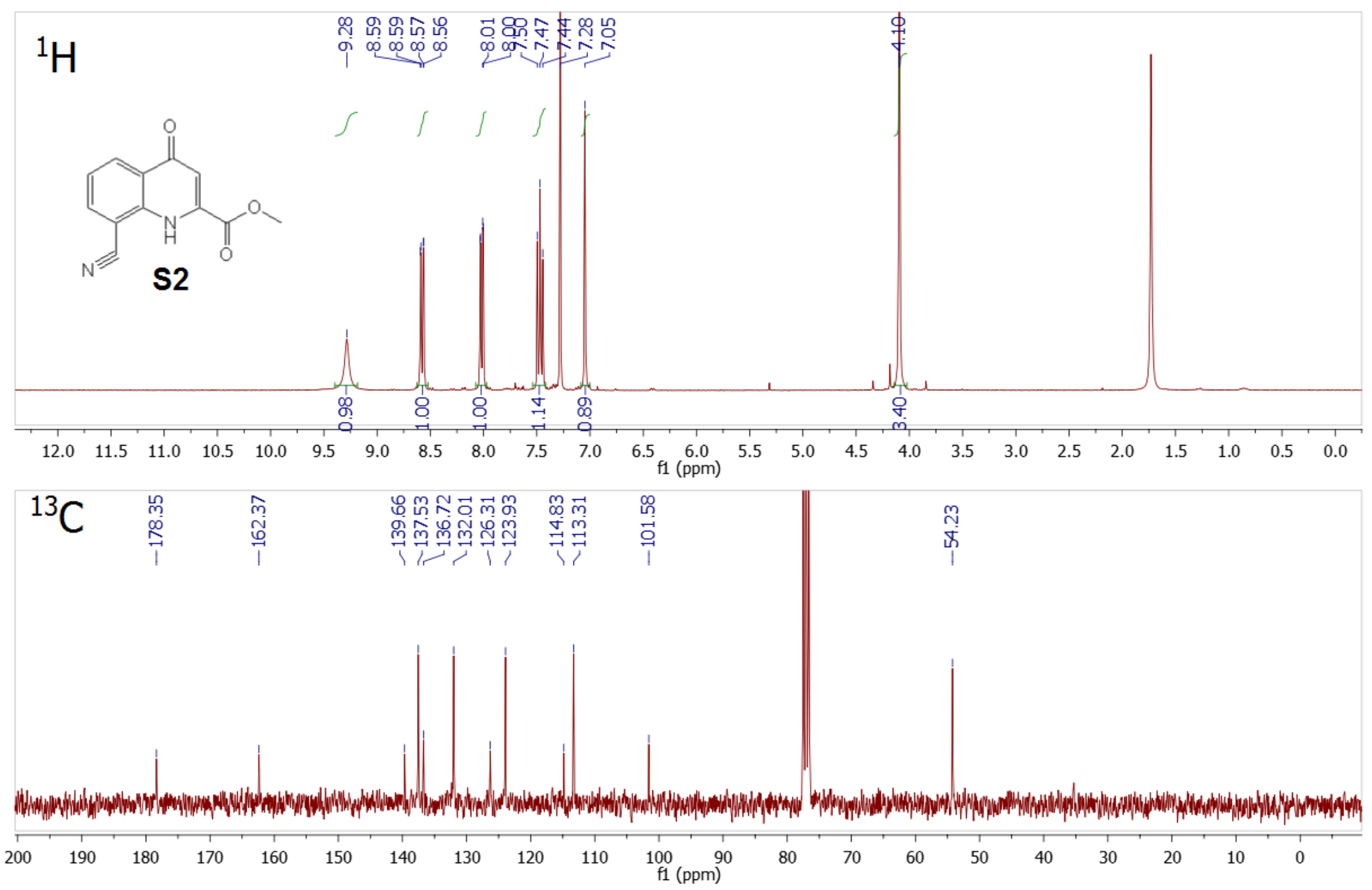

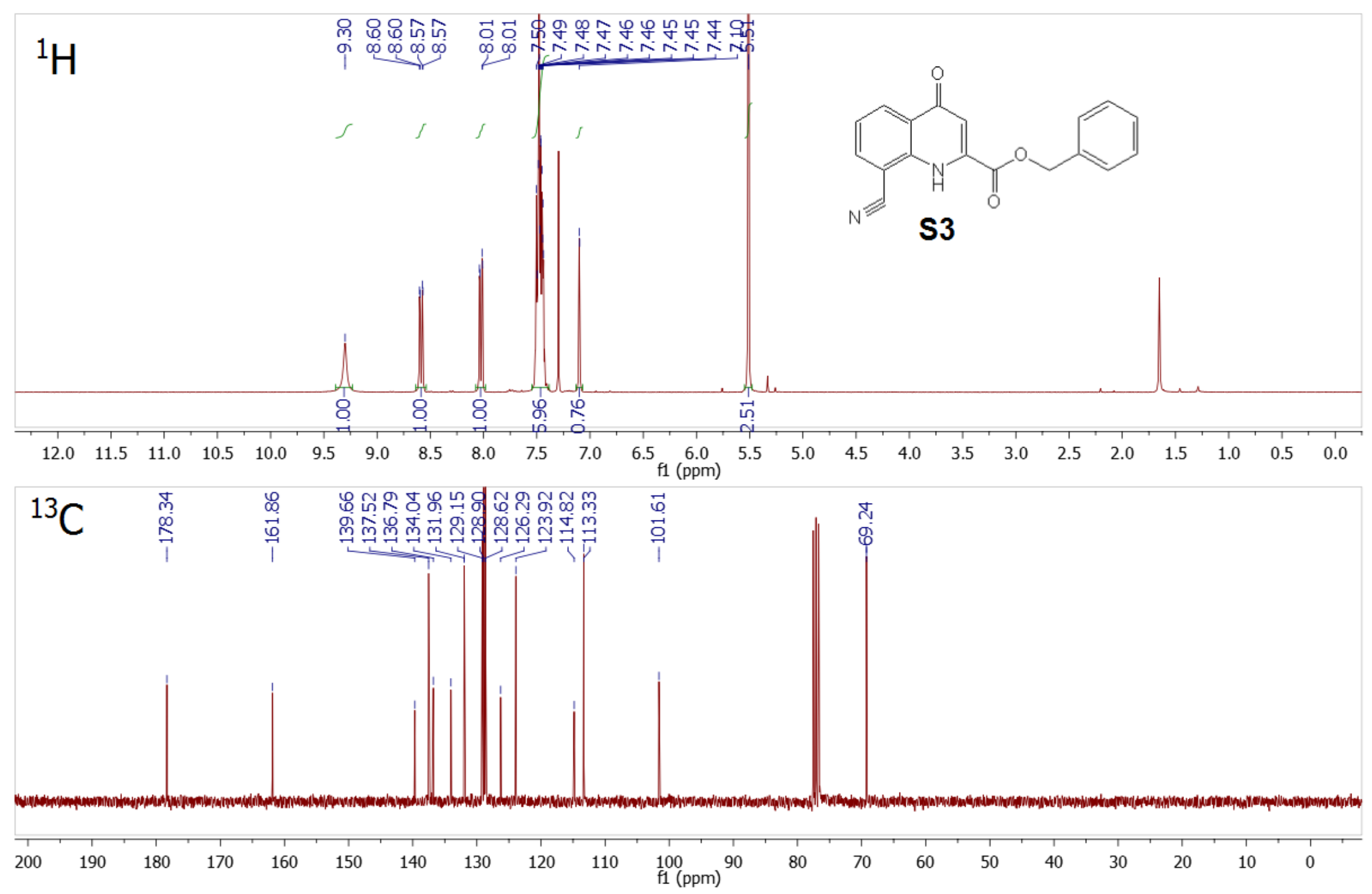

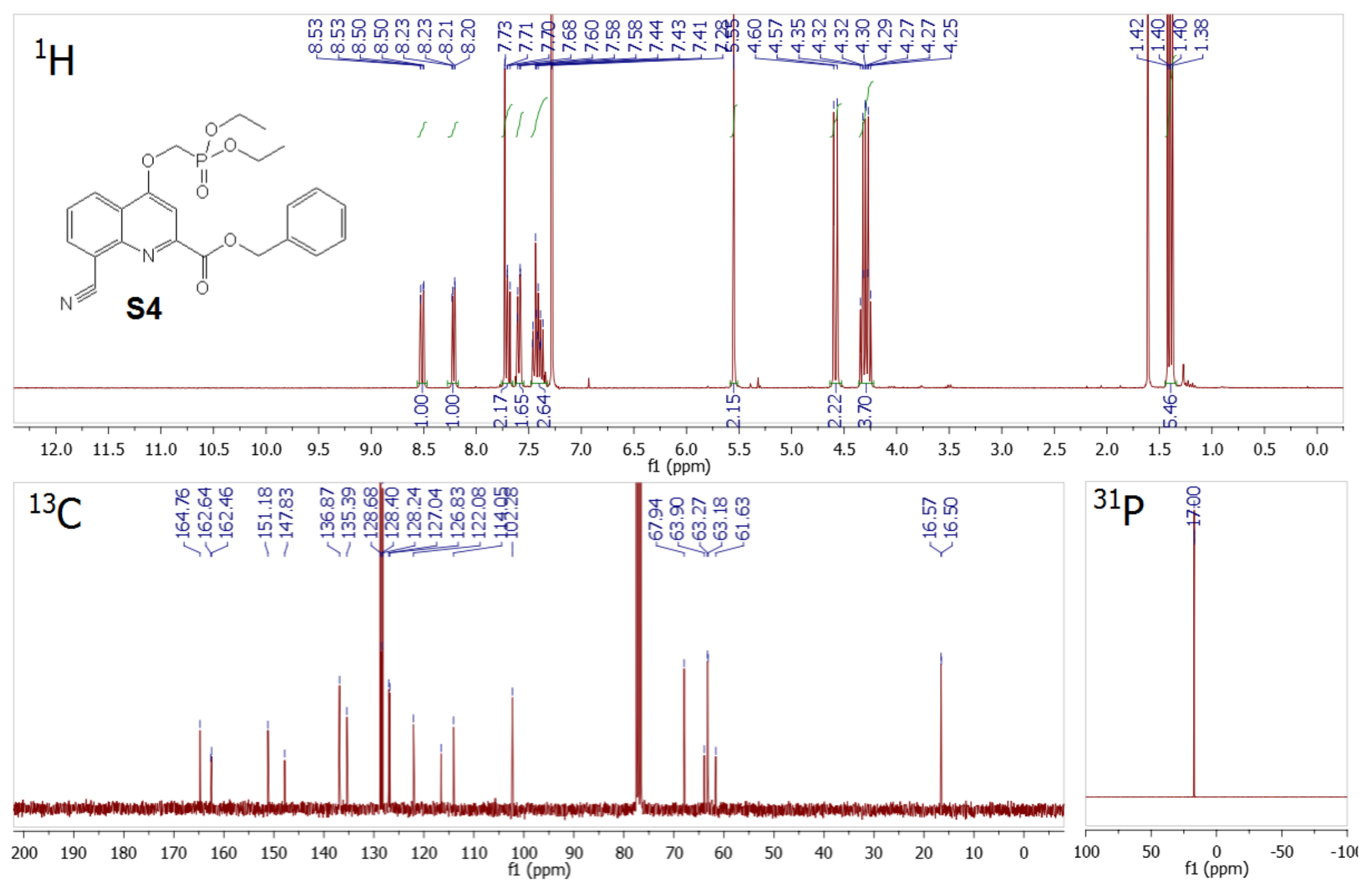


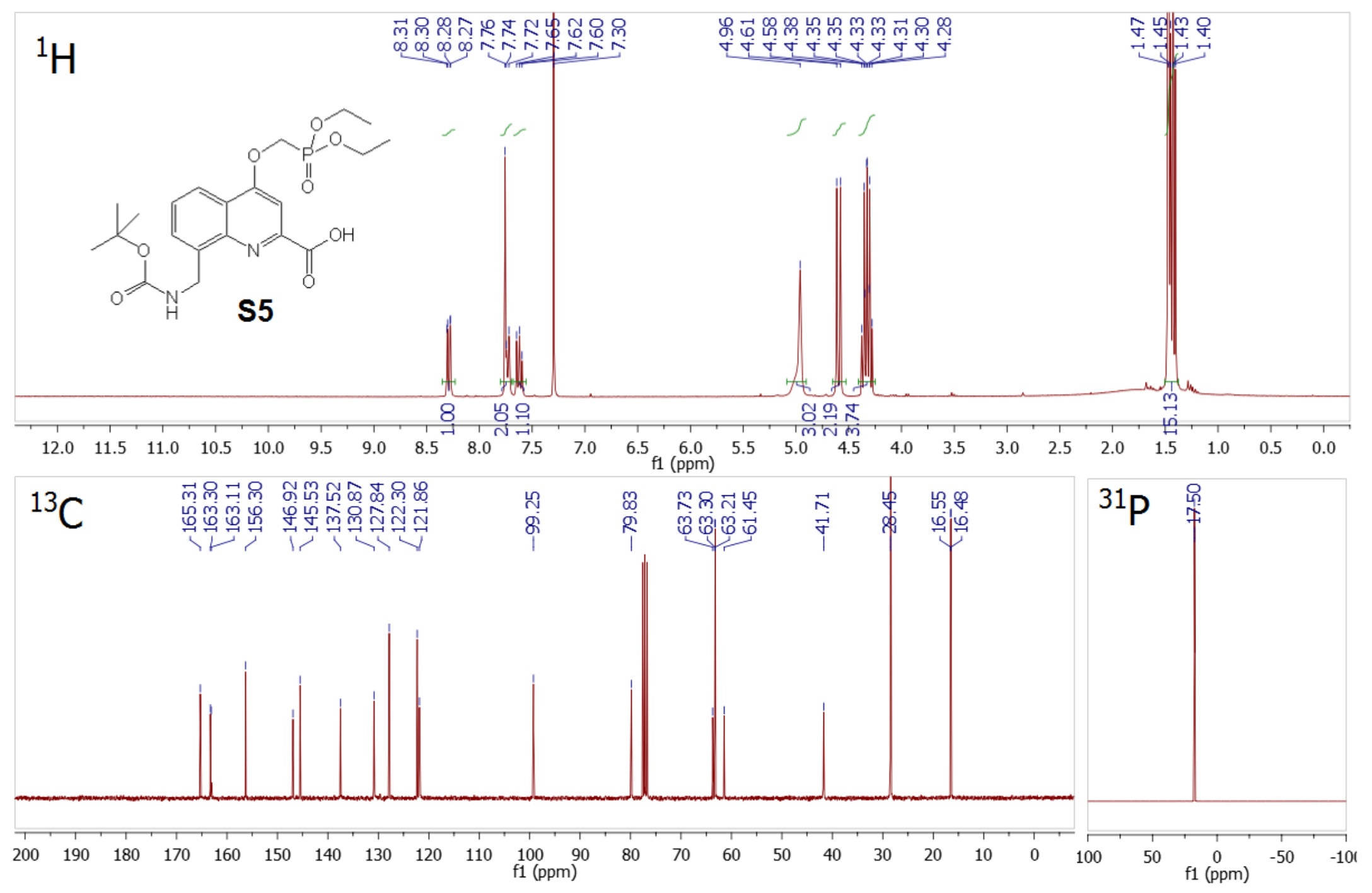




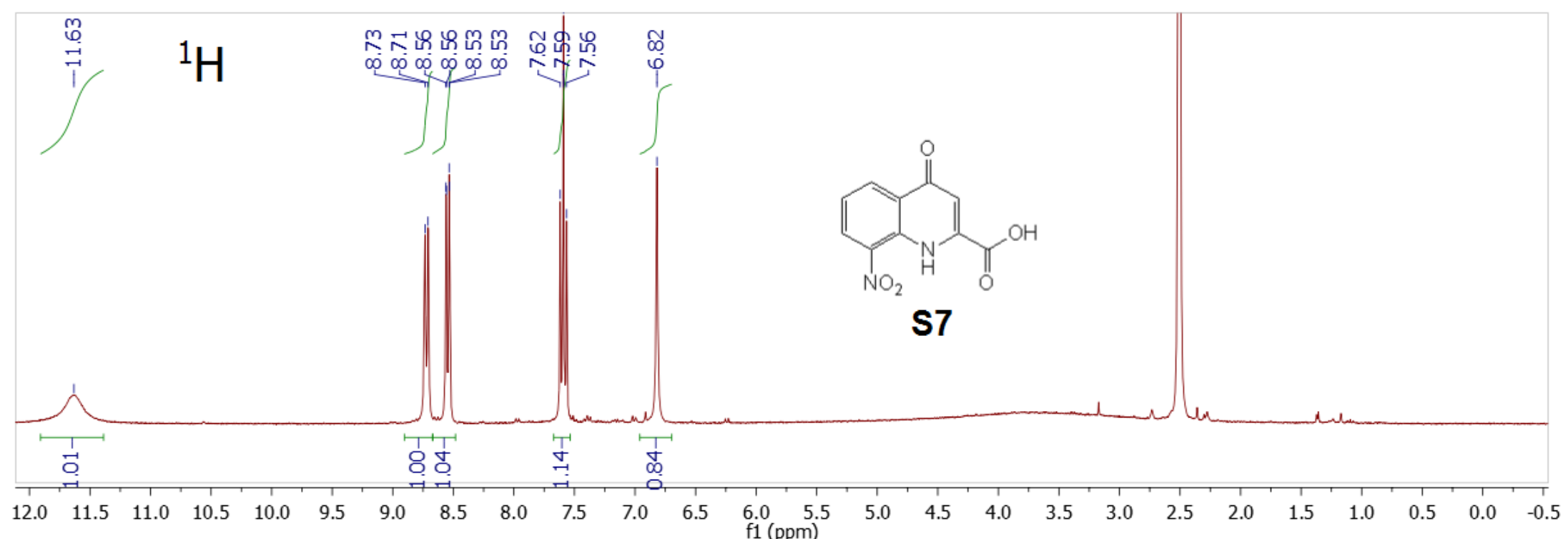

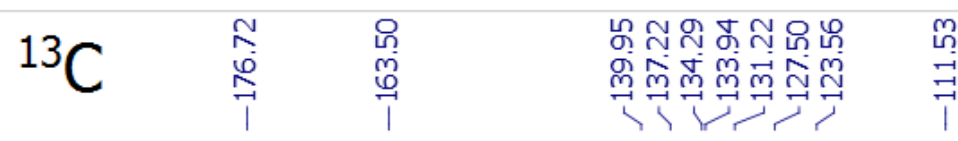

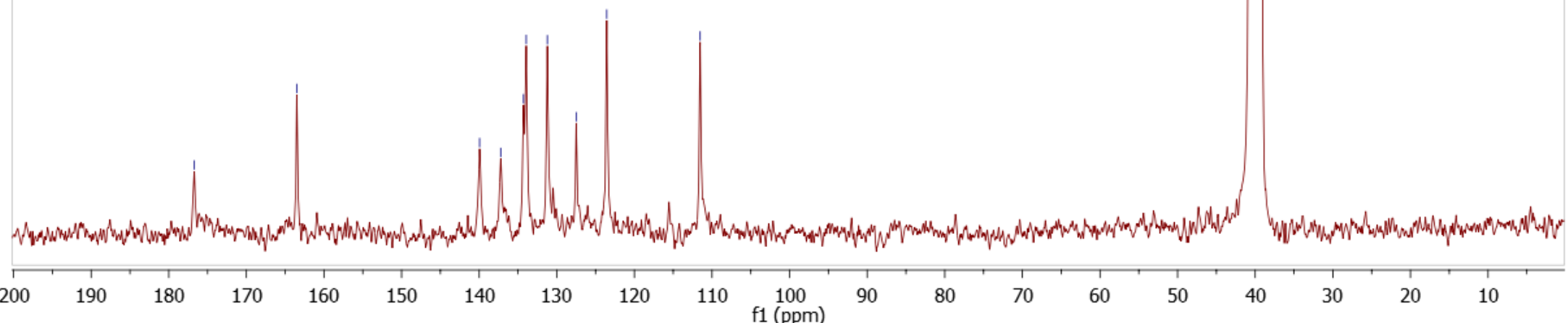



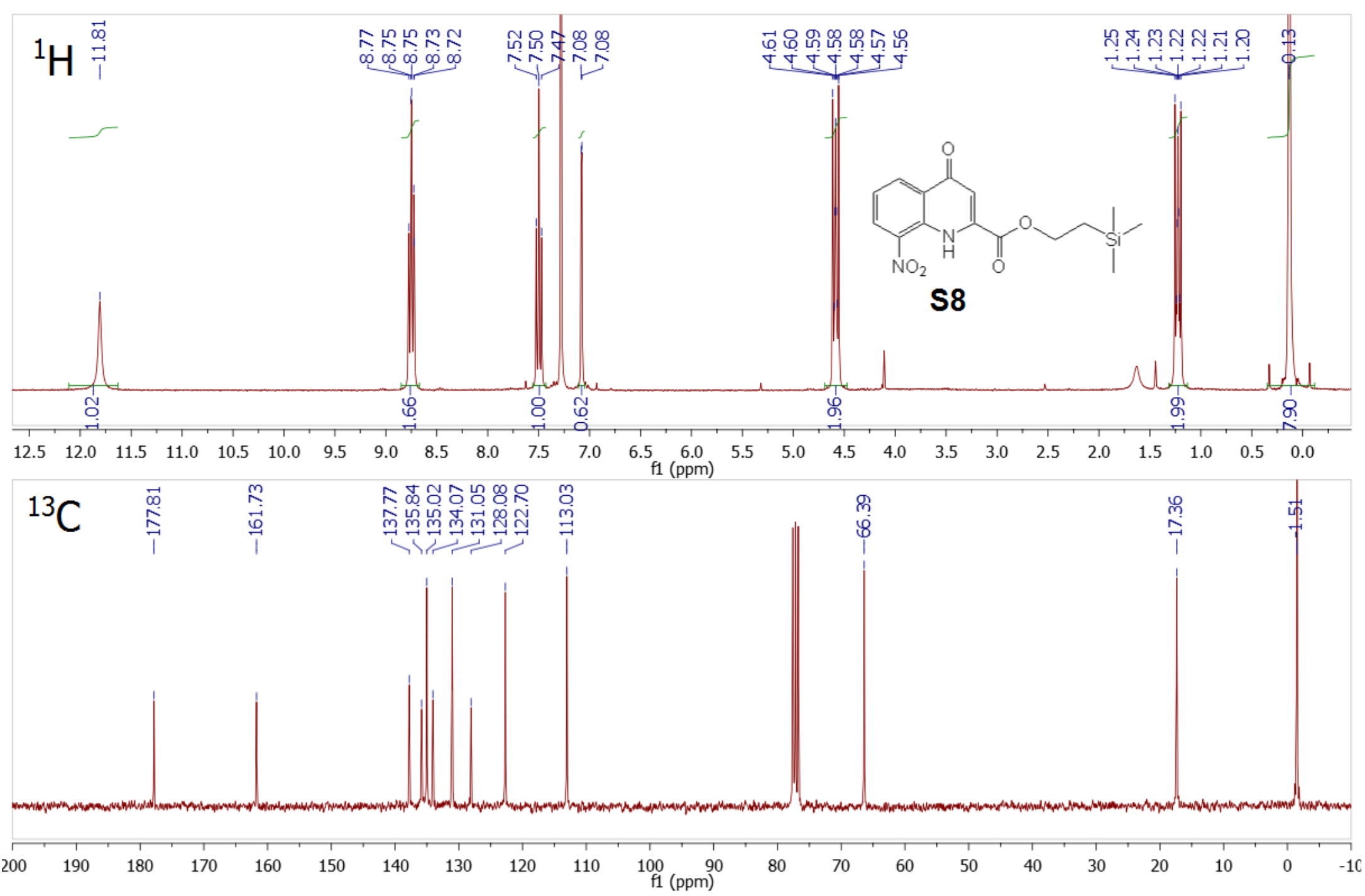


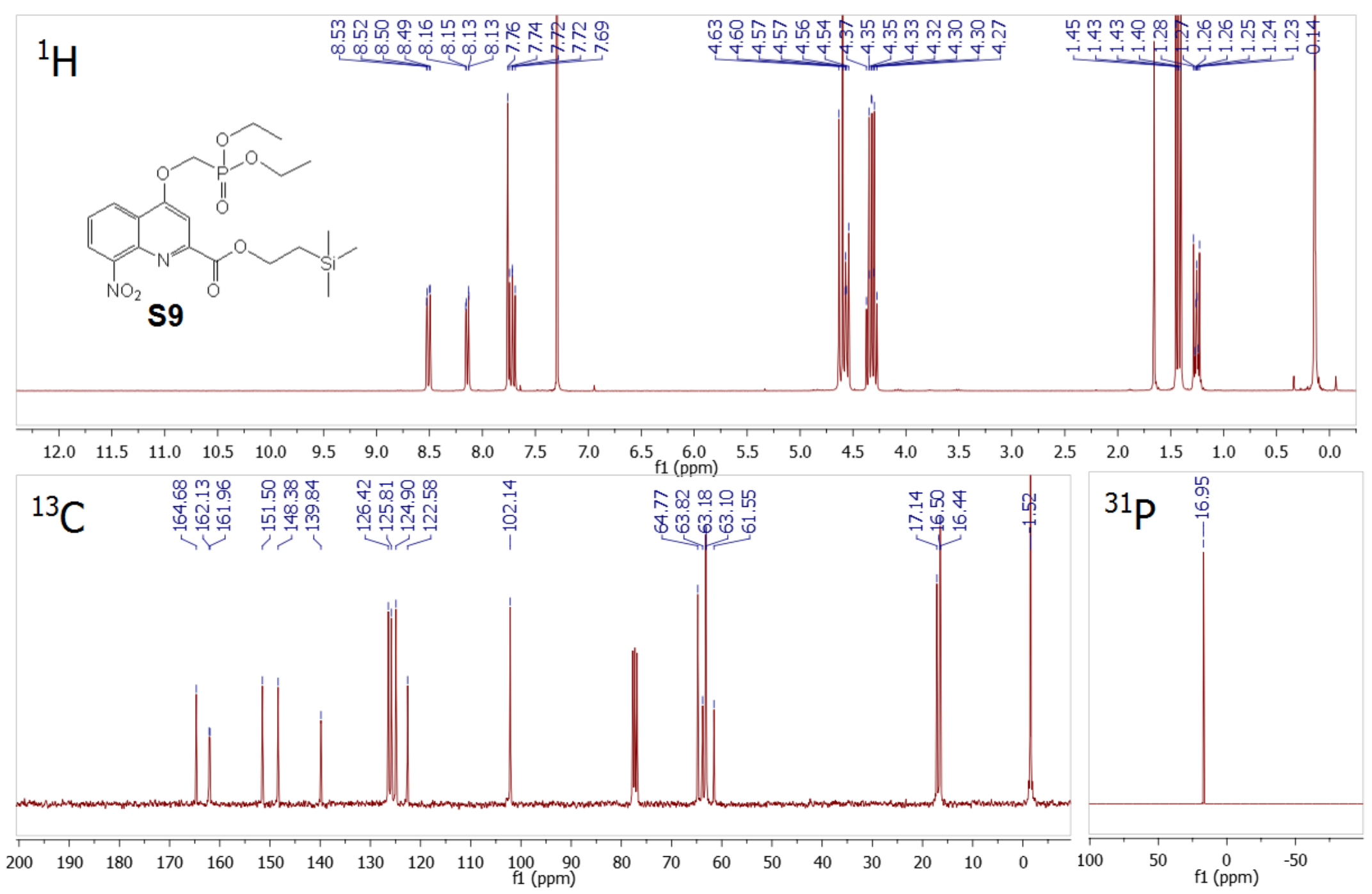




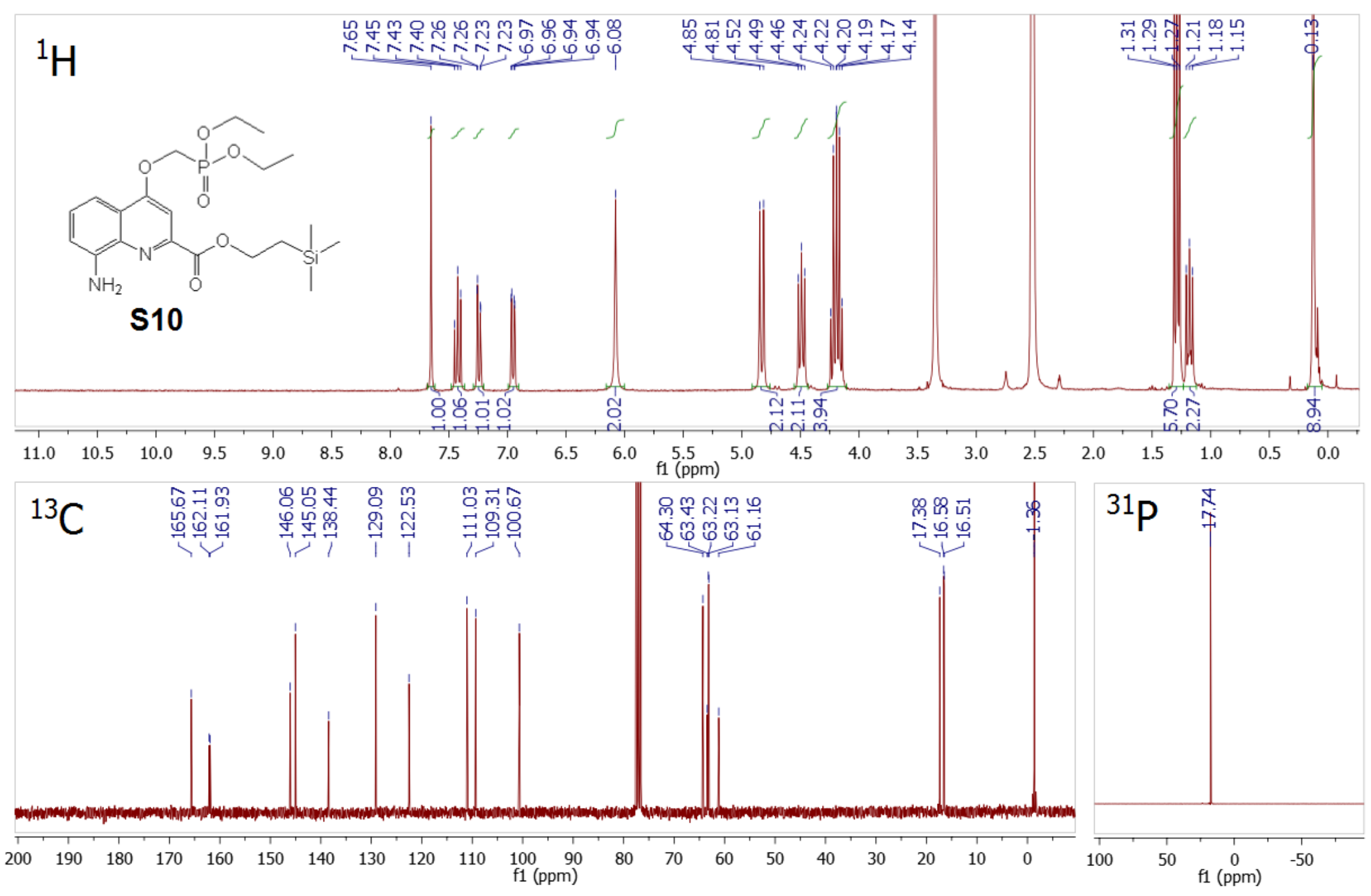




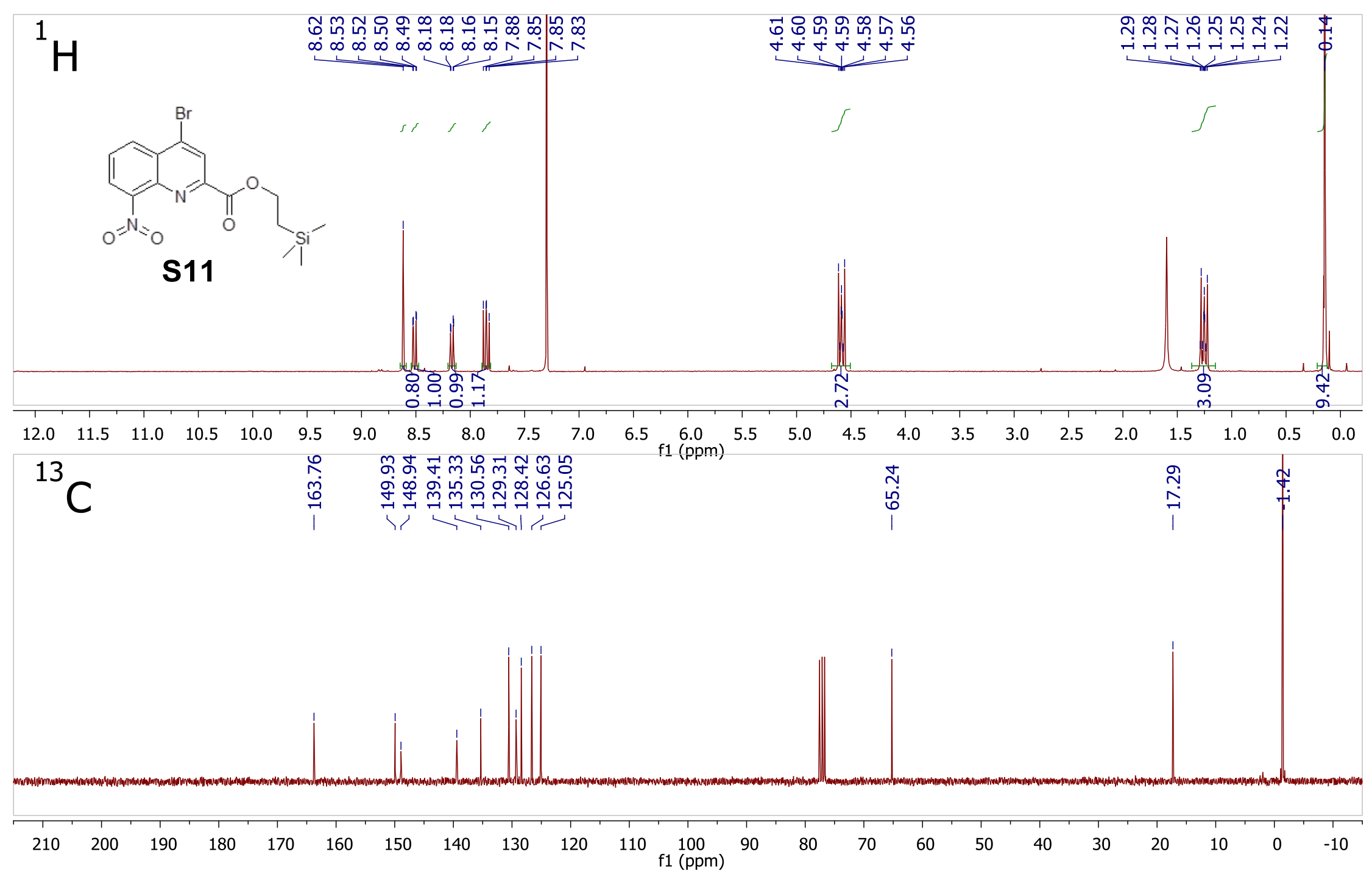




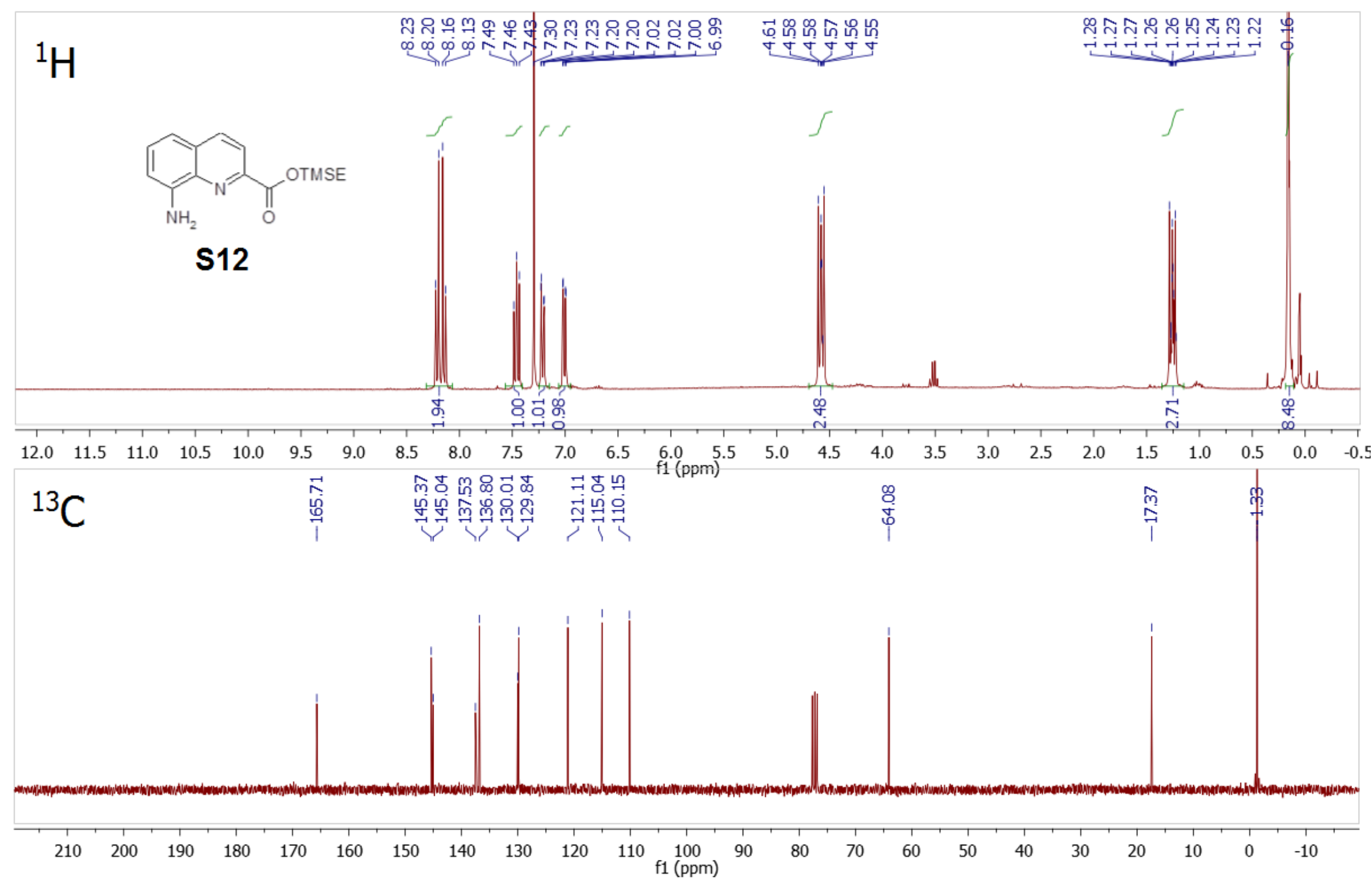




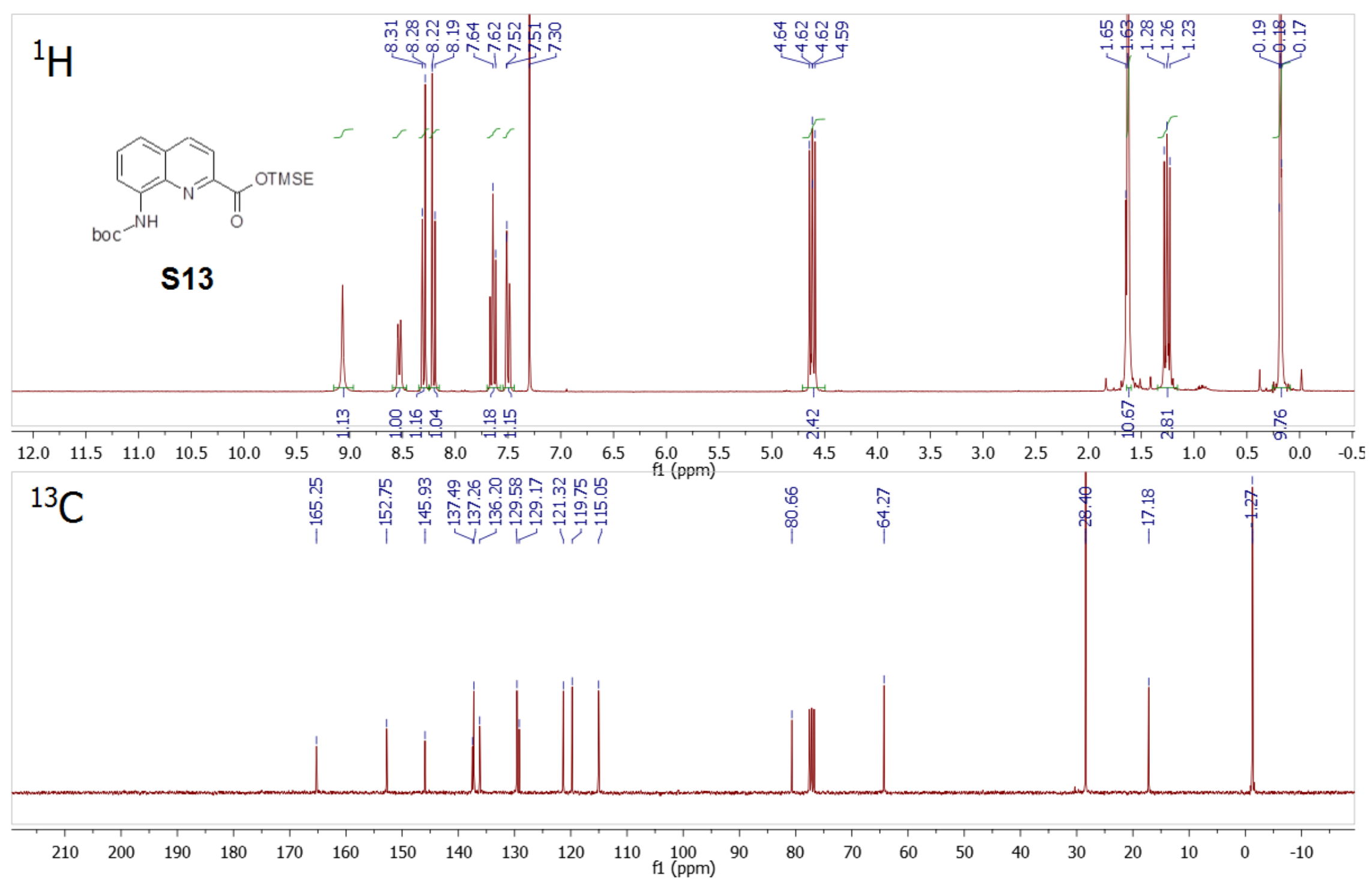




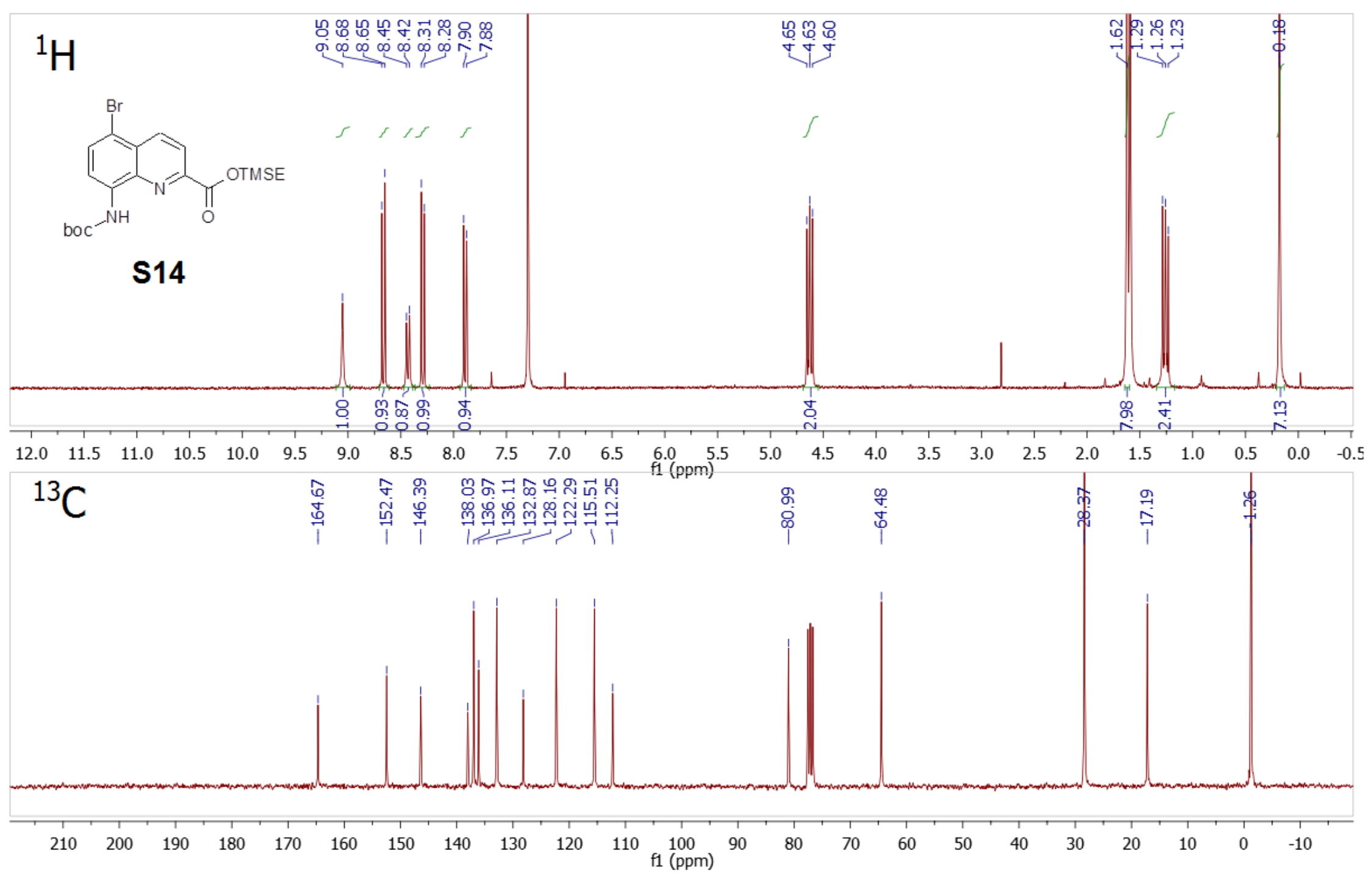




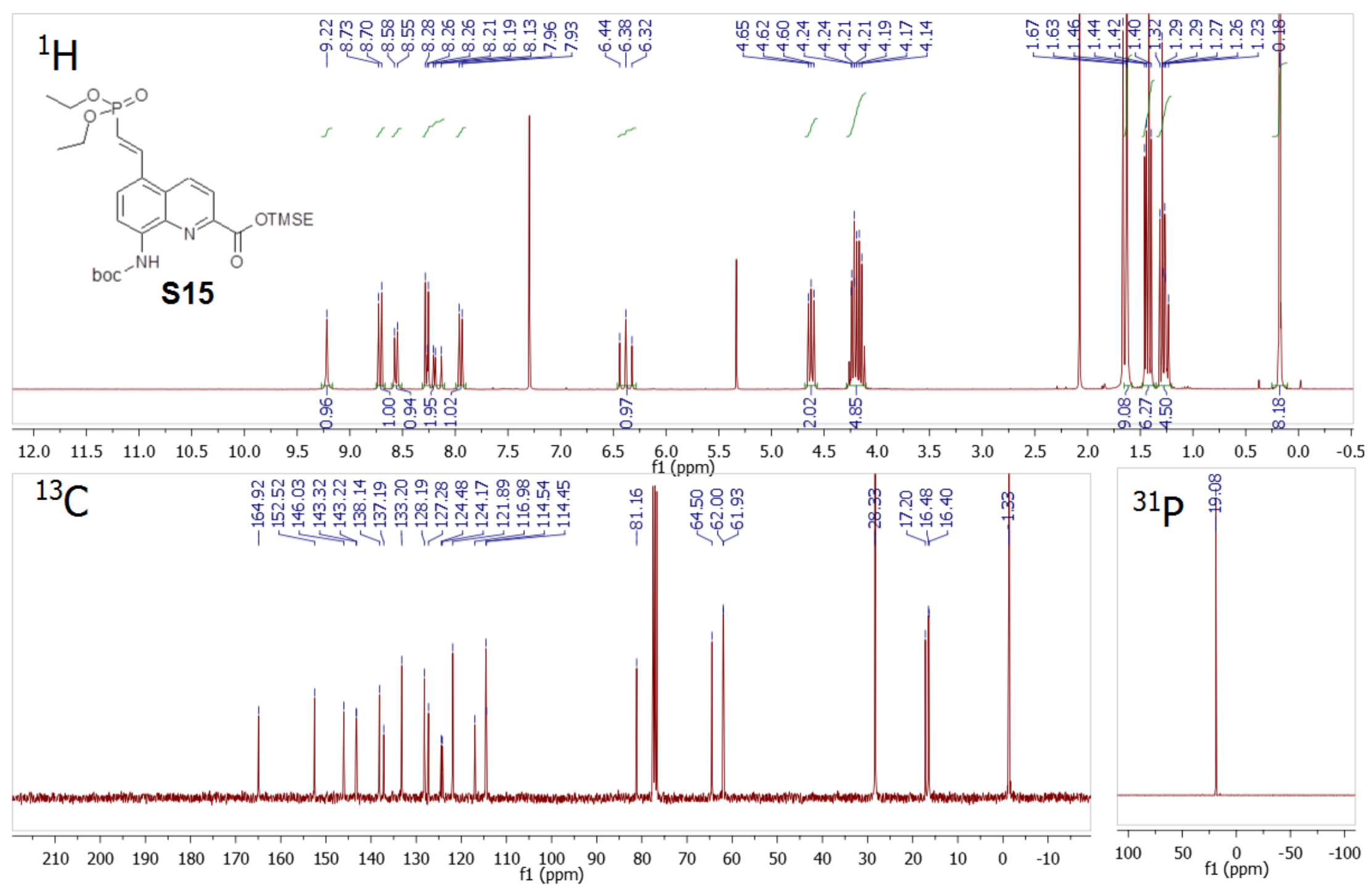




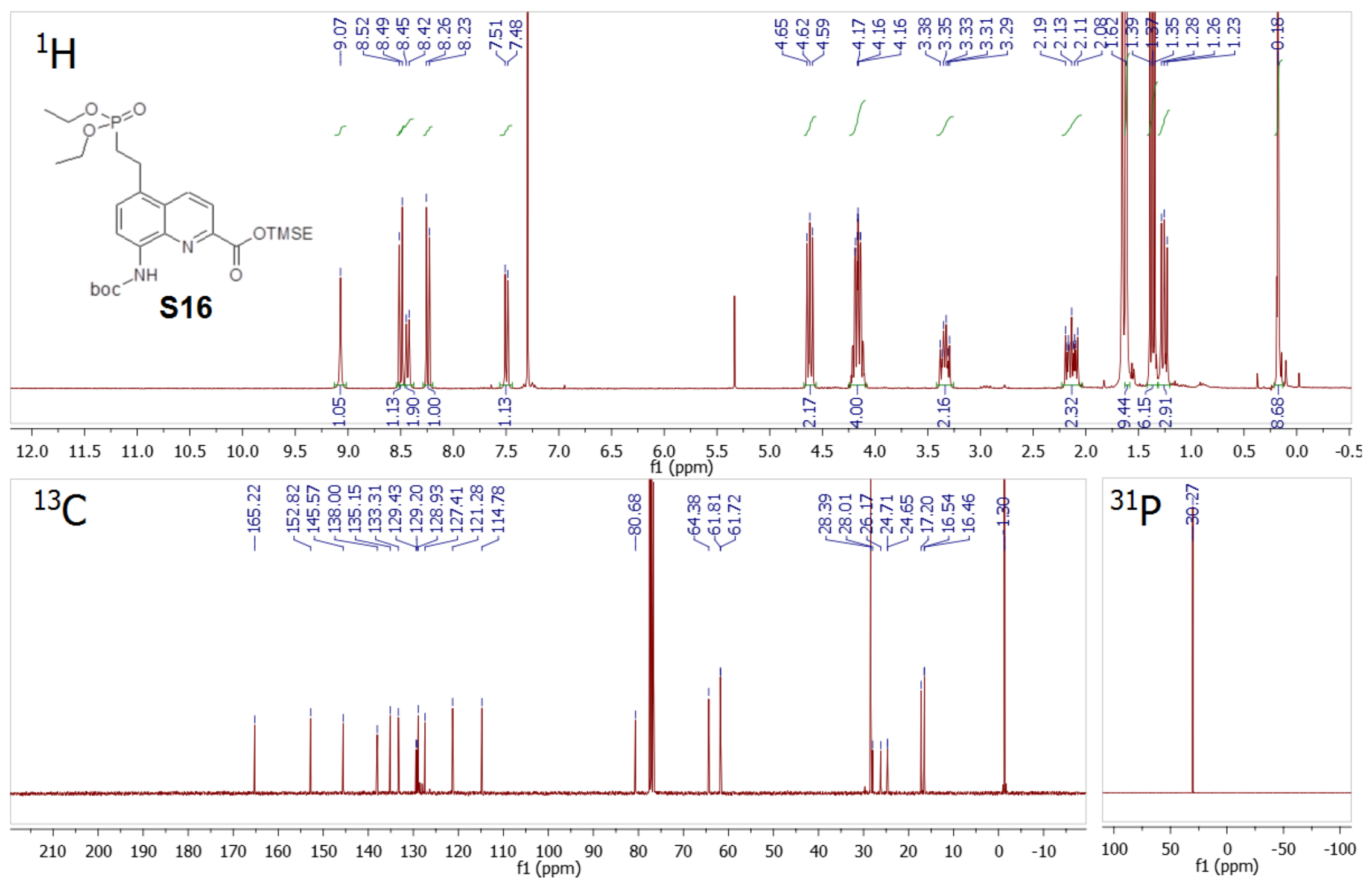



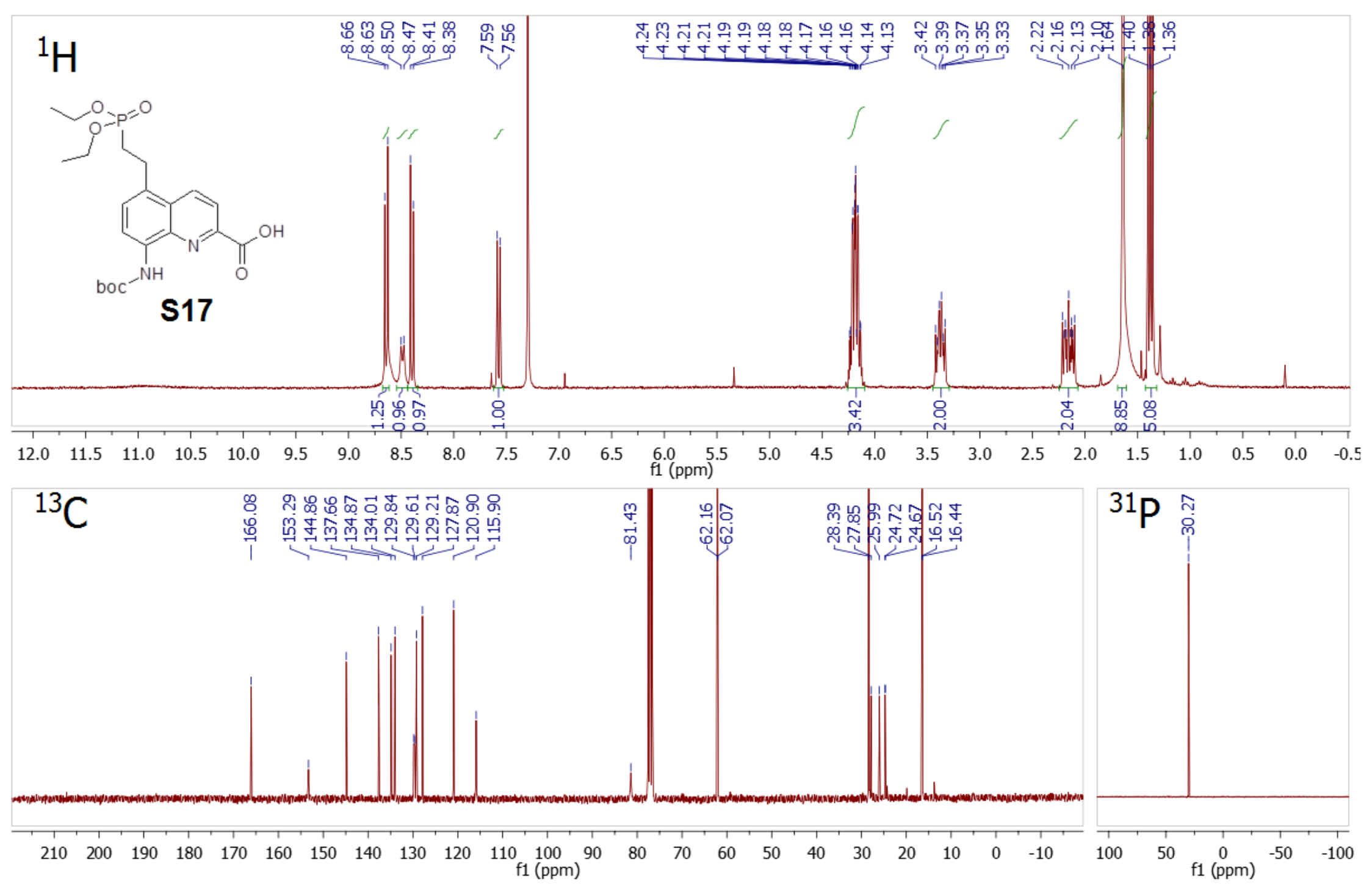


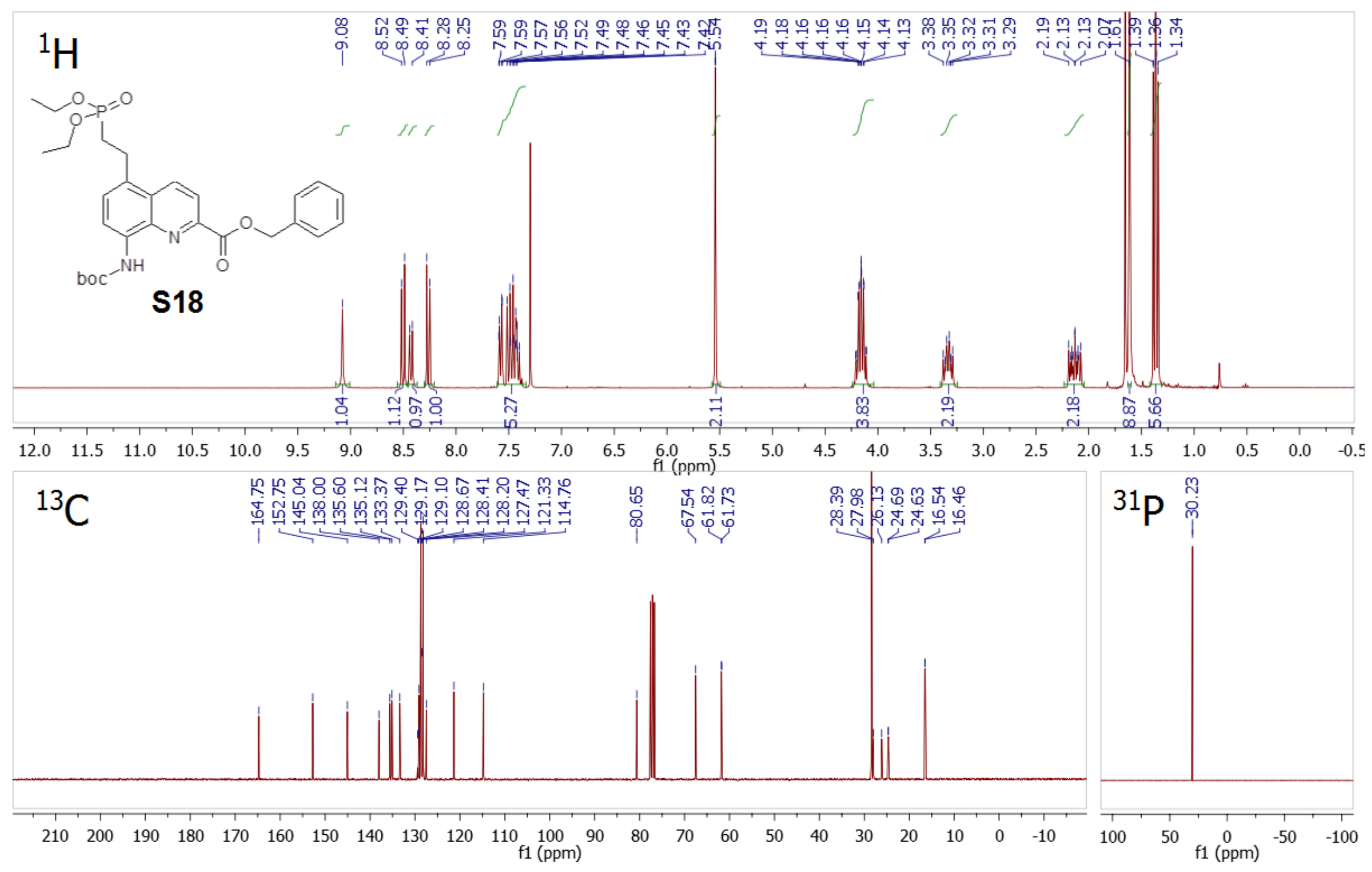




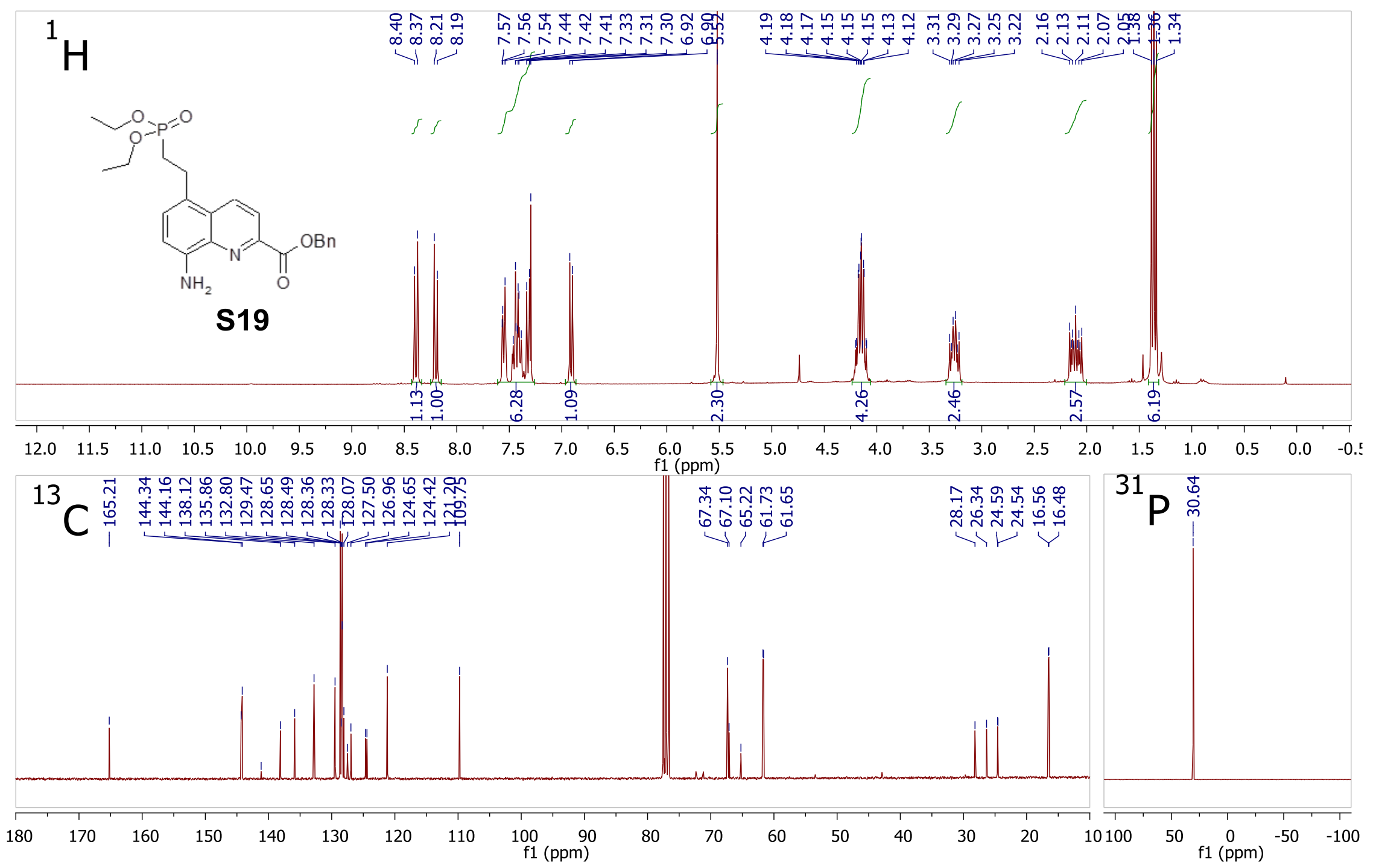




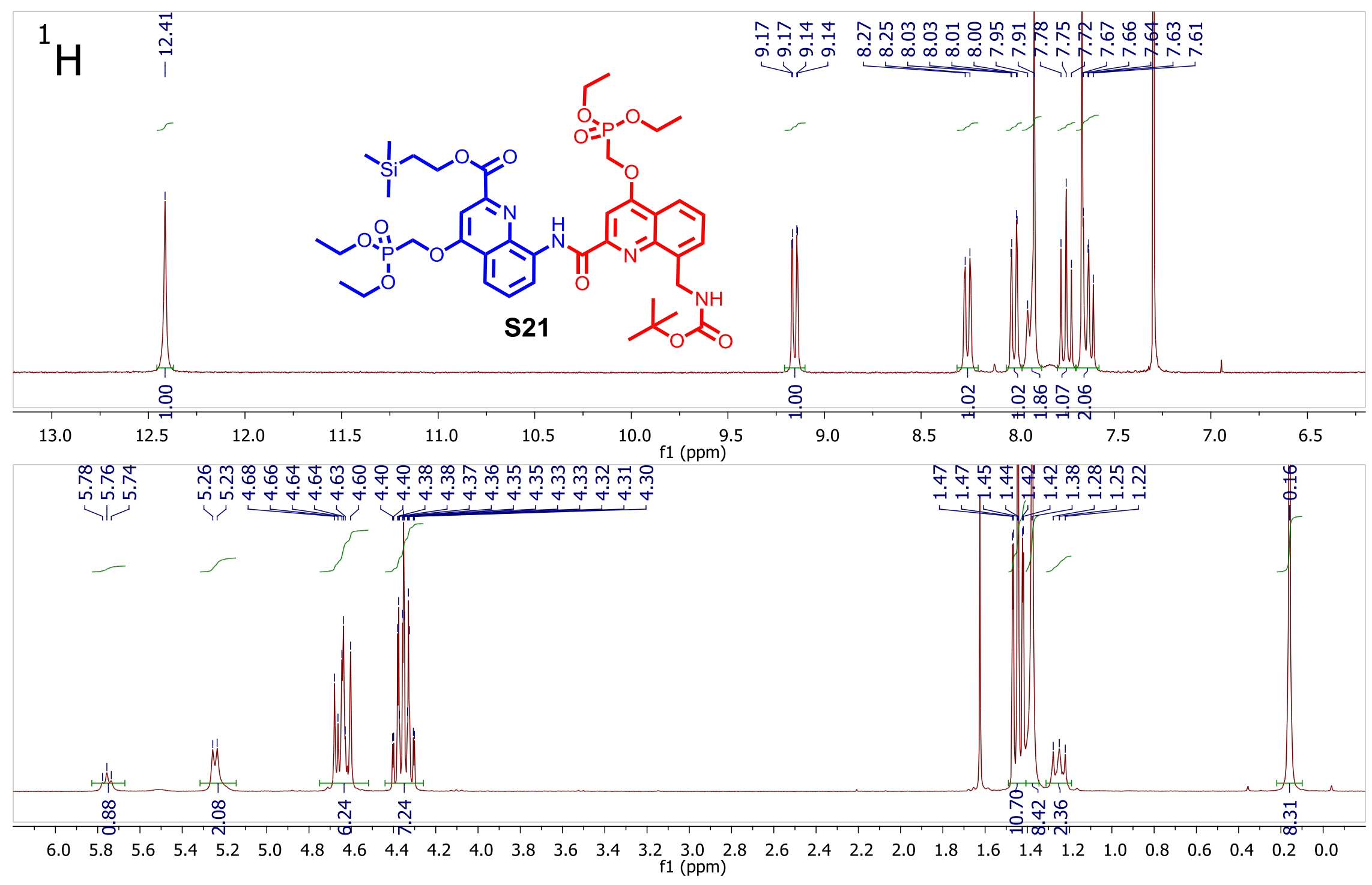



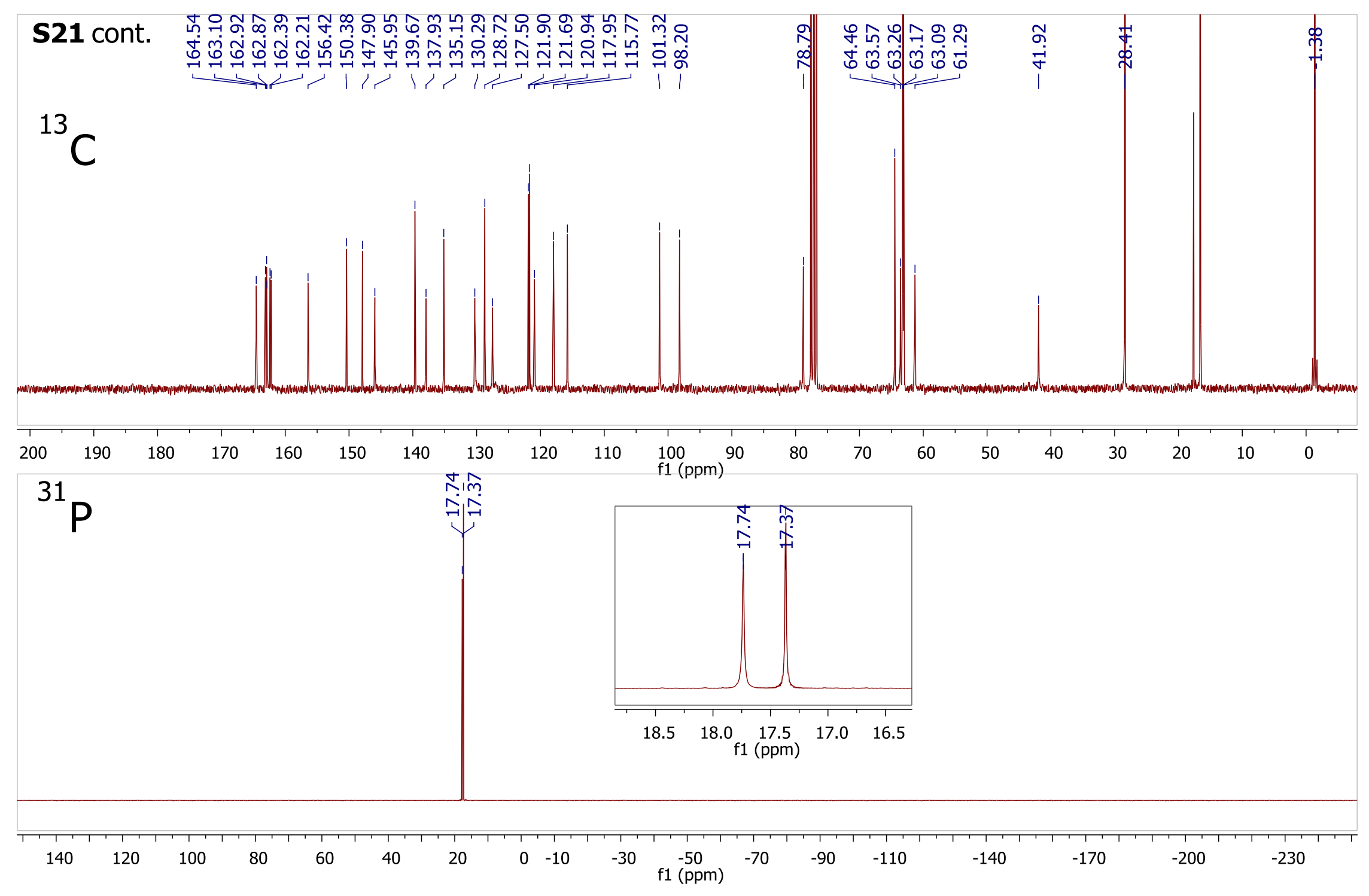


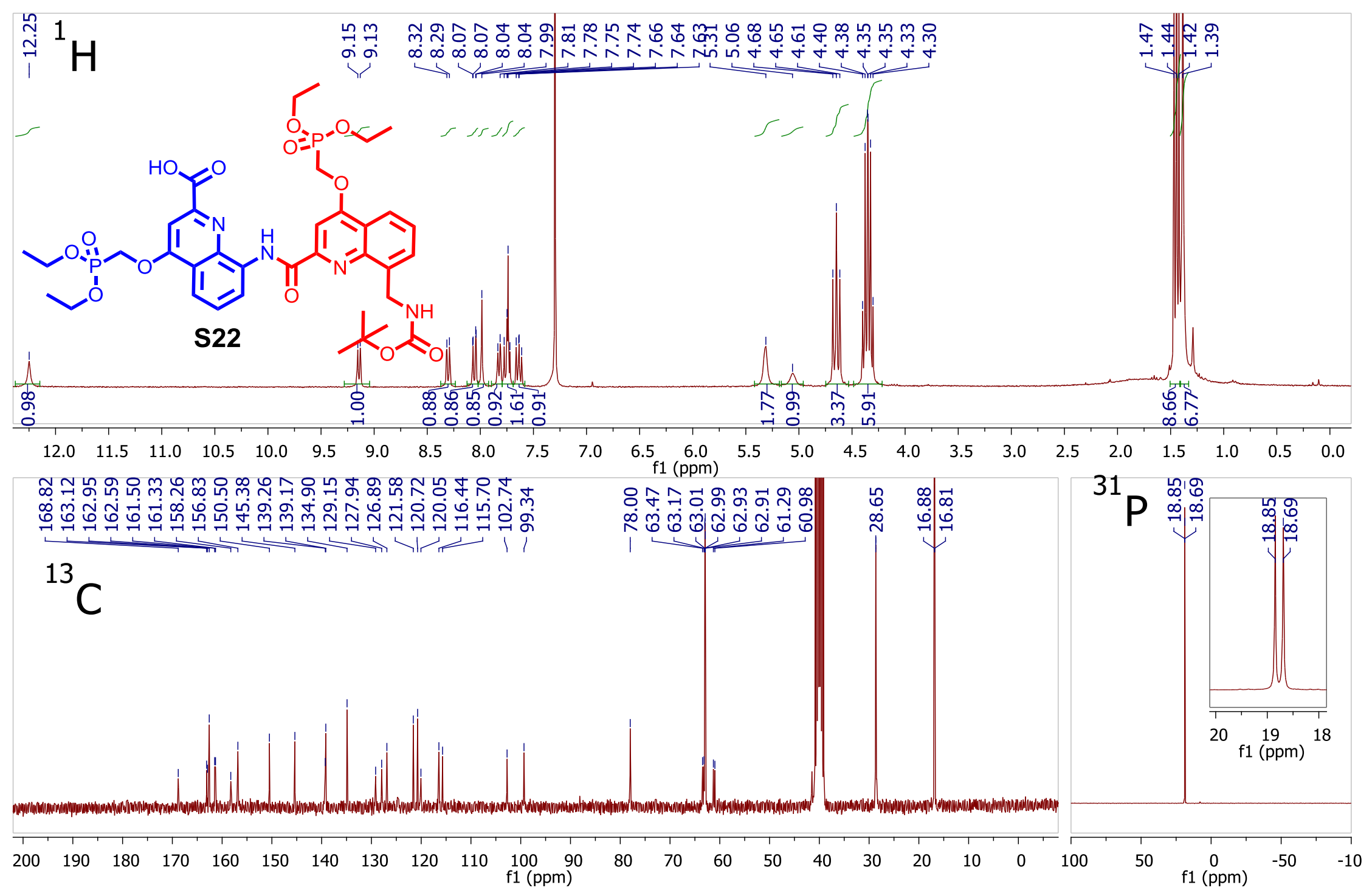




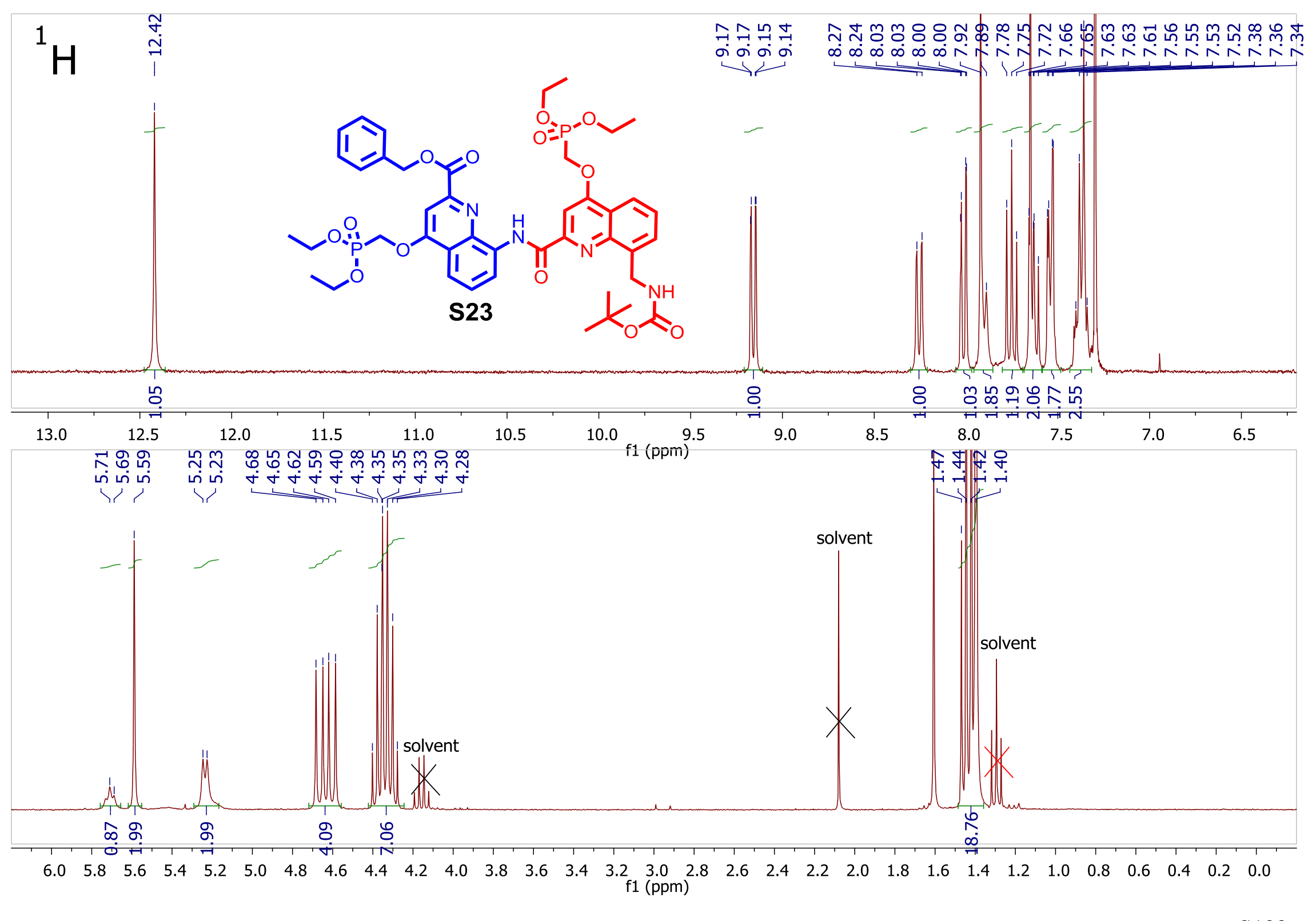




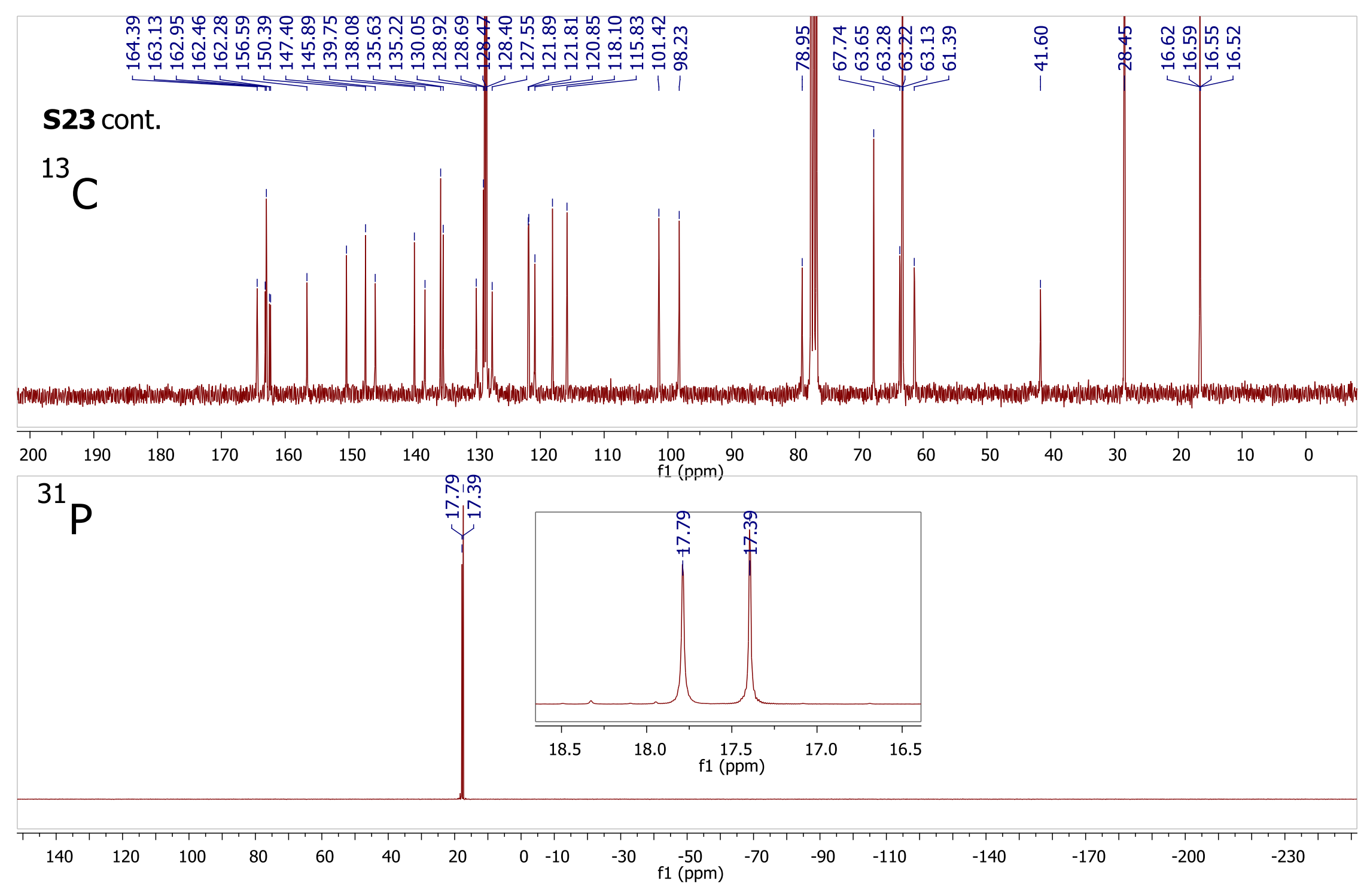




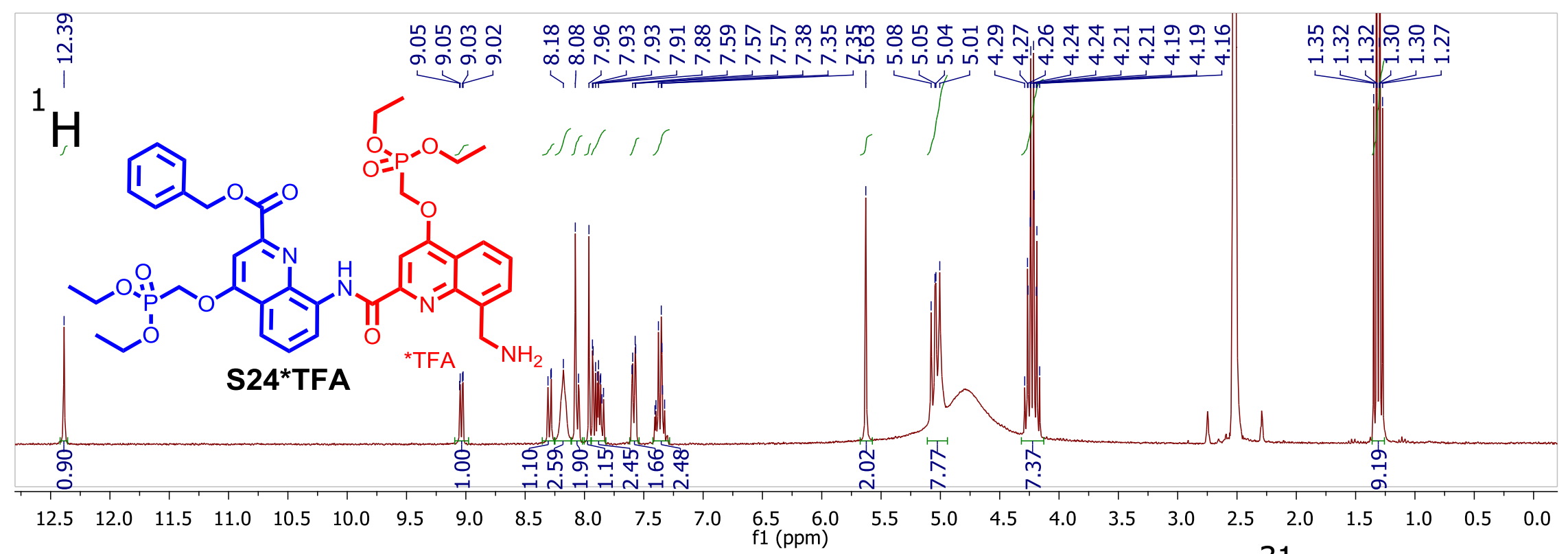

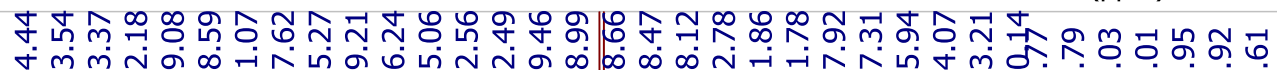

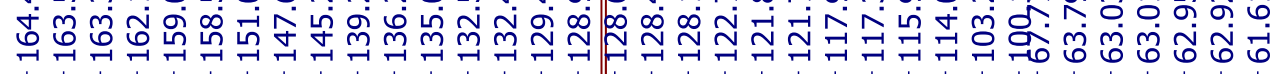

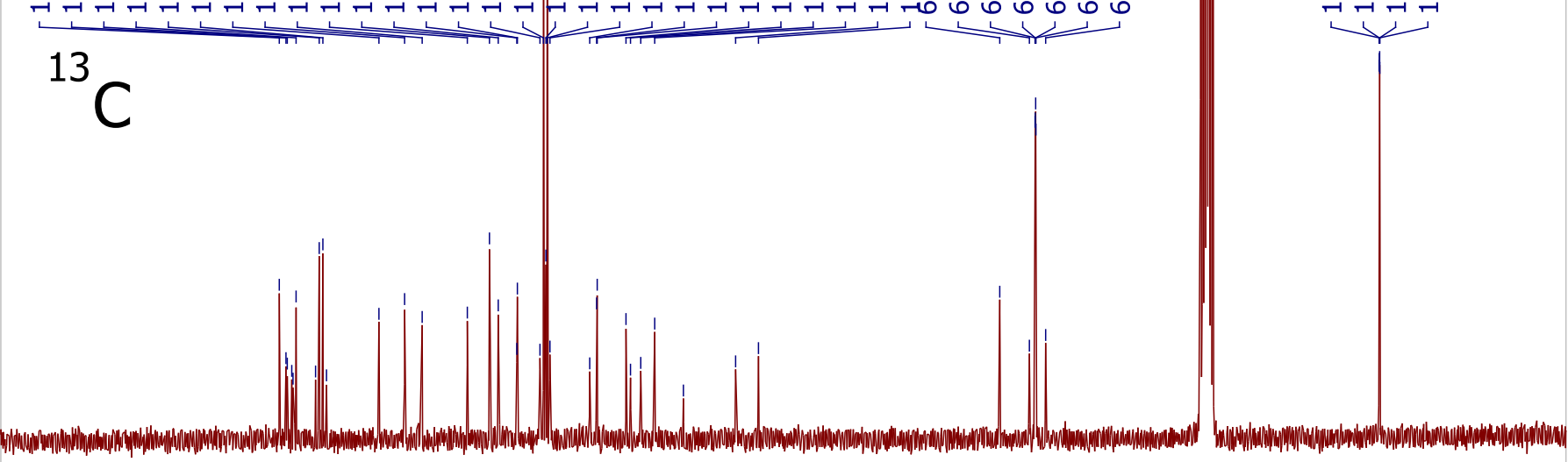

$\begin{array}{lllllllllll}200 & 190 & 180 & 170 & 160 & 150 & 140 & 130 & 120 & 110 & 100\end{array}$ f1 (ppm)

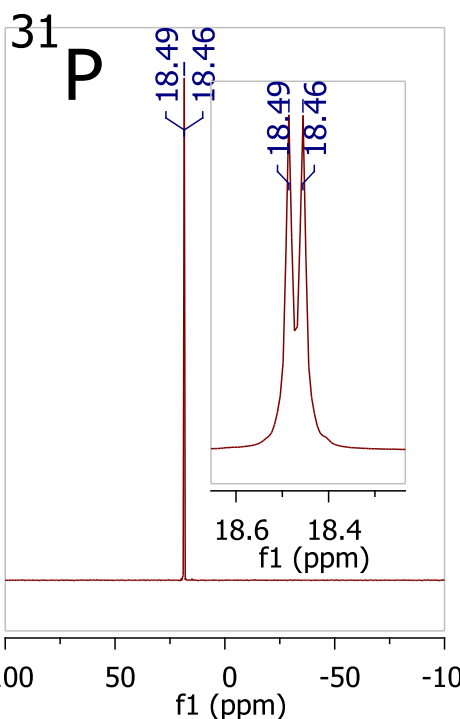




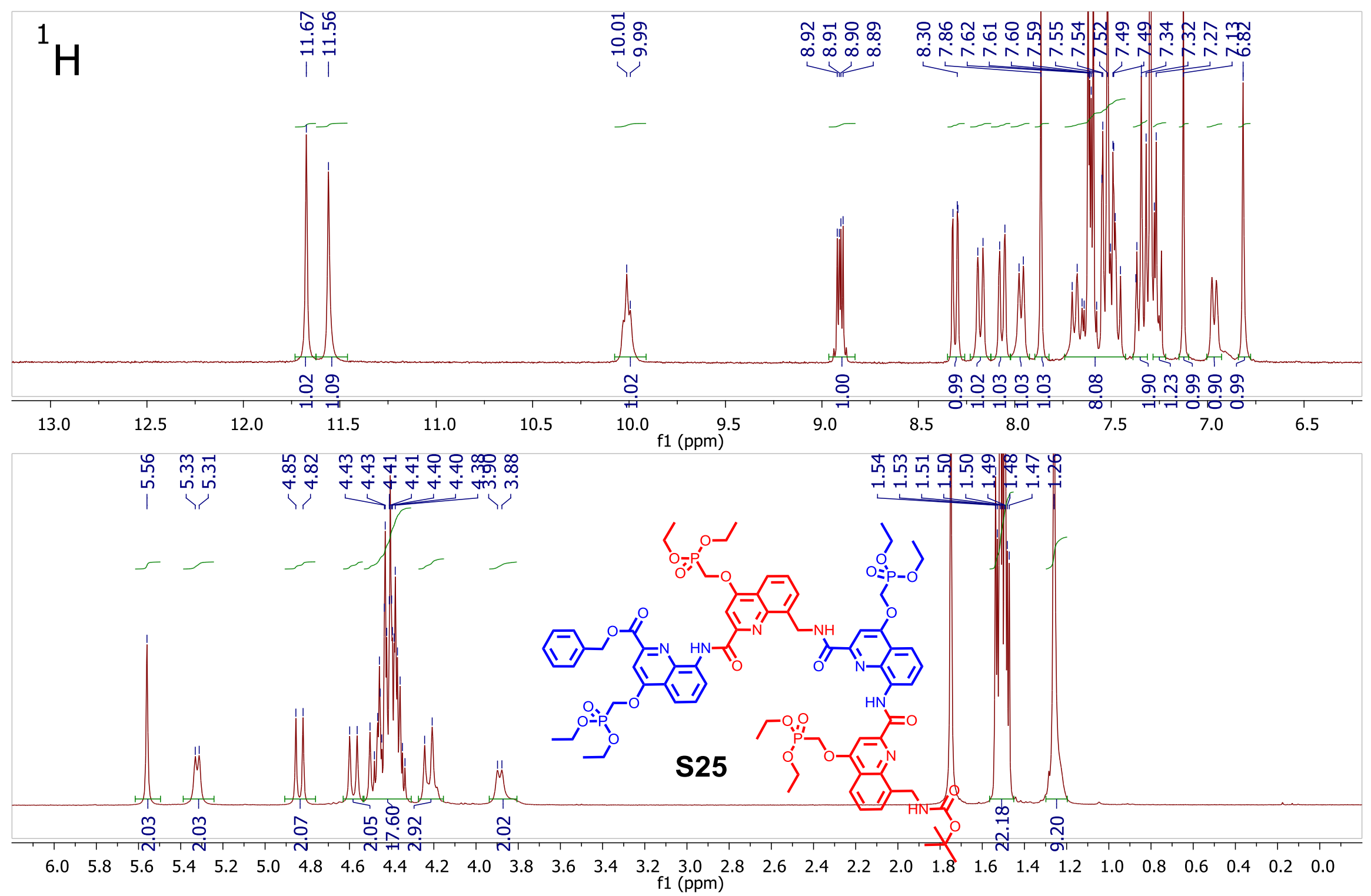




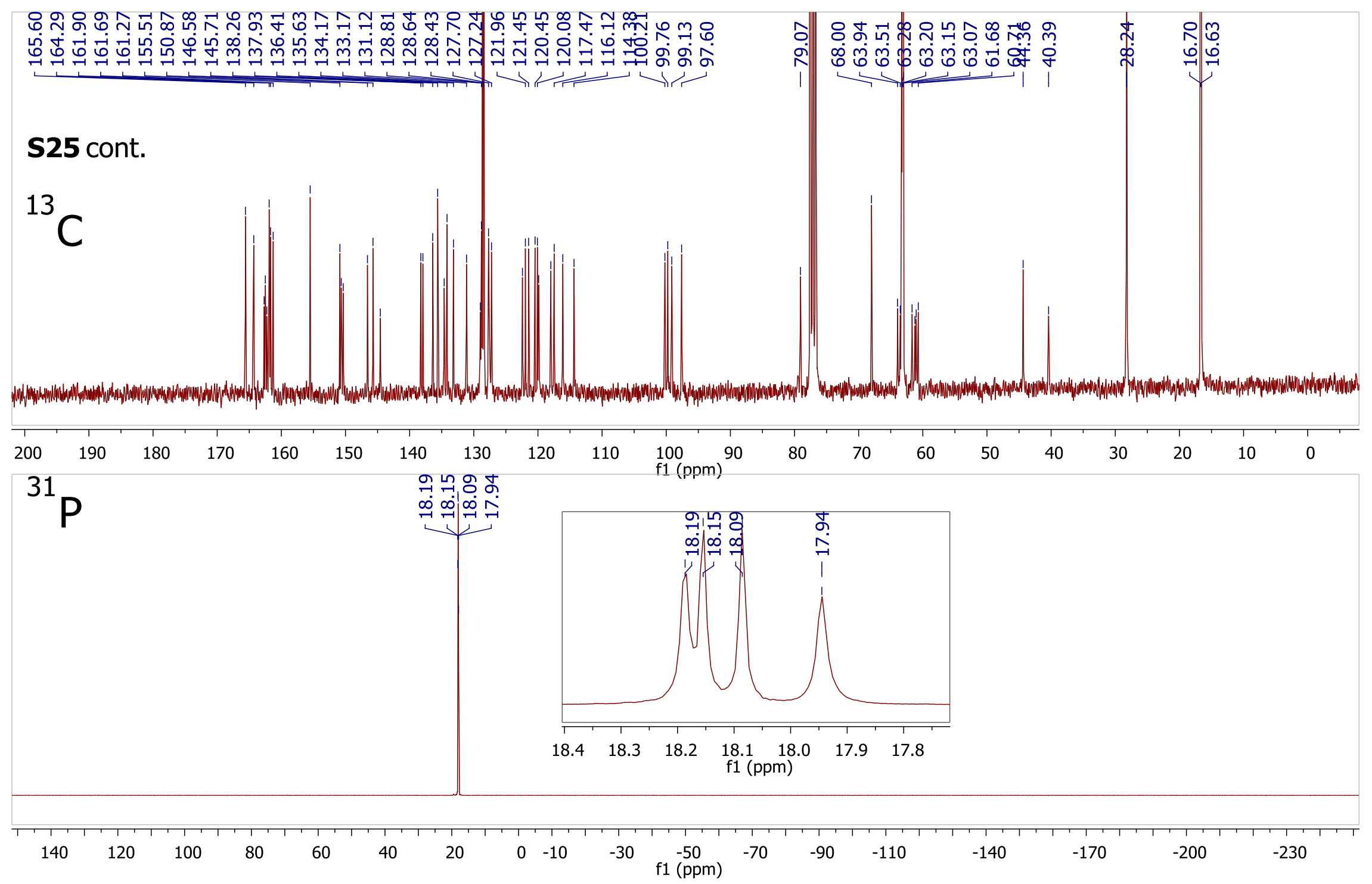



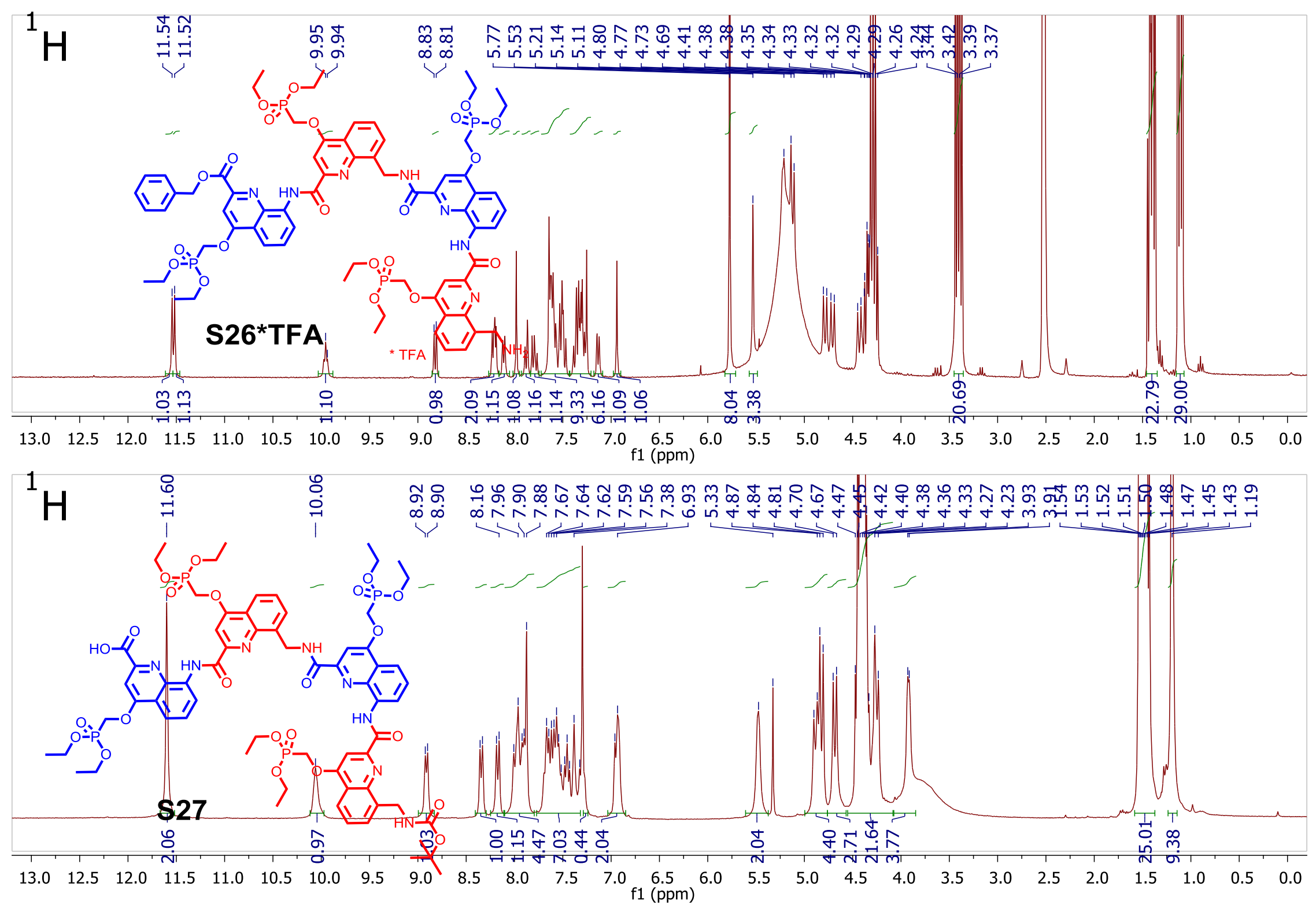


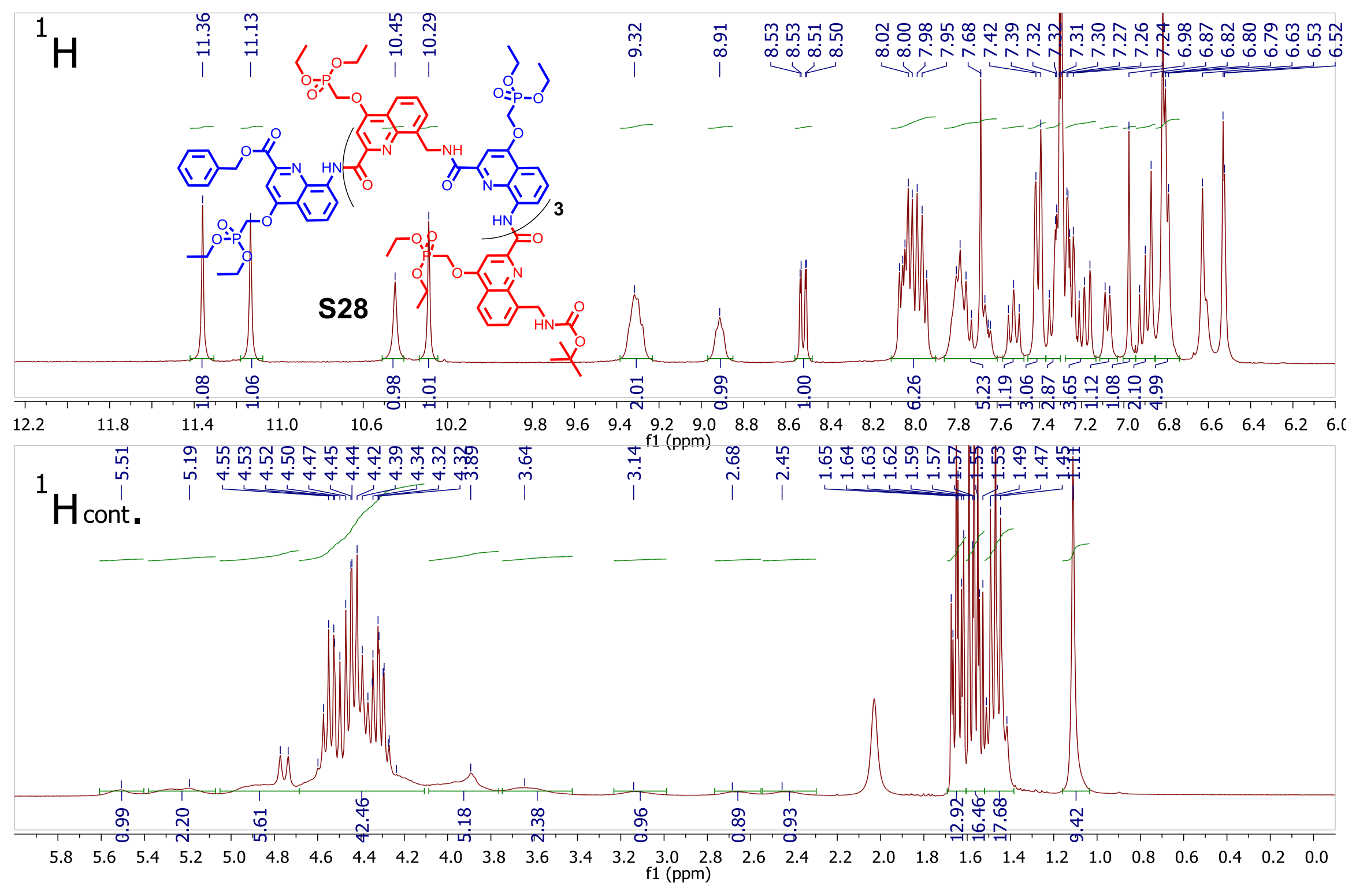


กำ m

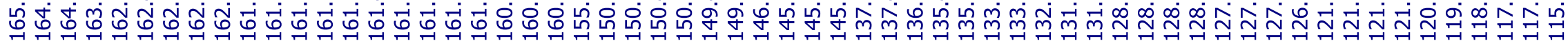

\section{S28 cont.}

${ }^{13}$ C, J-Mod

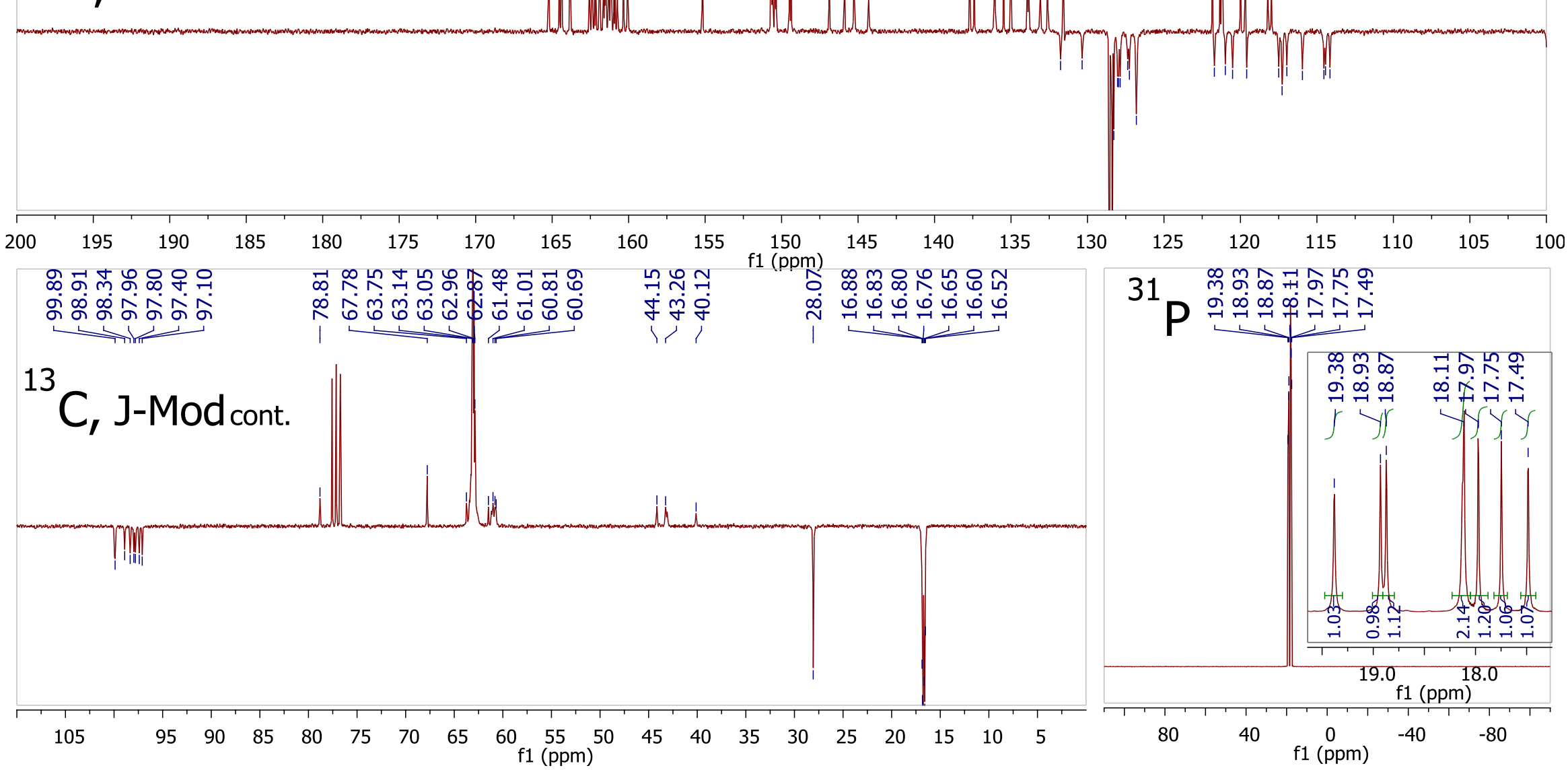



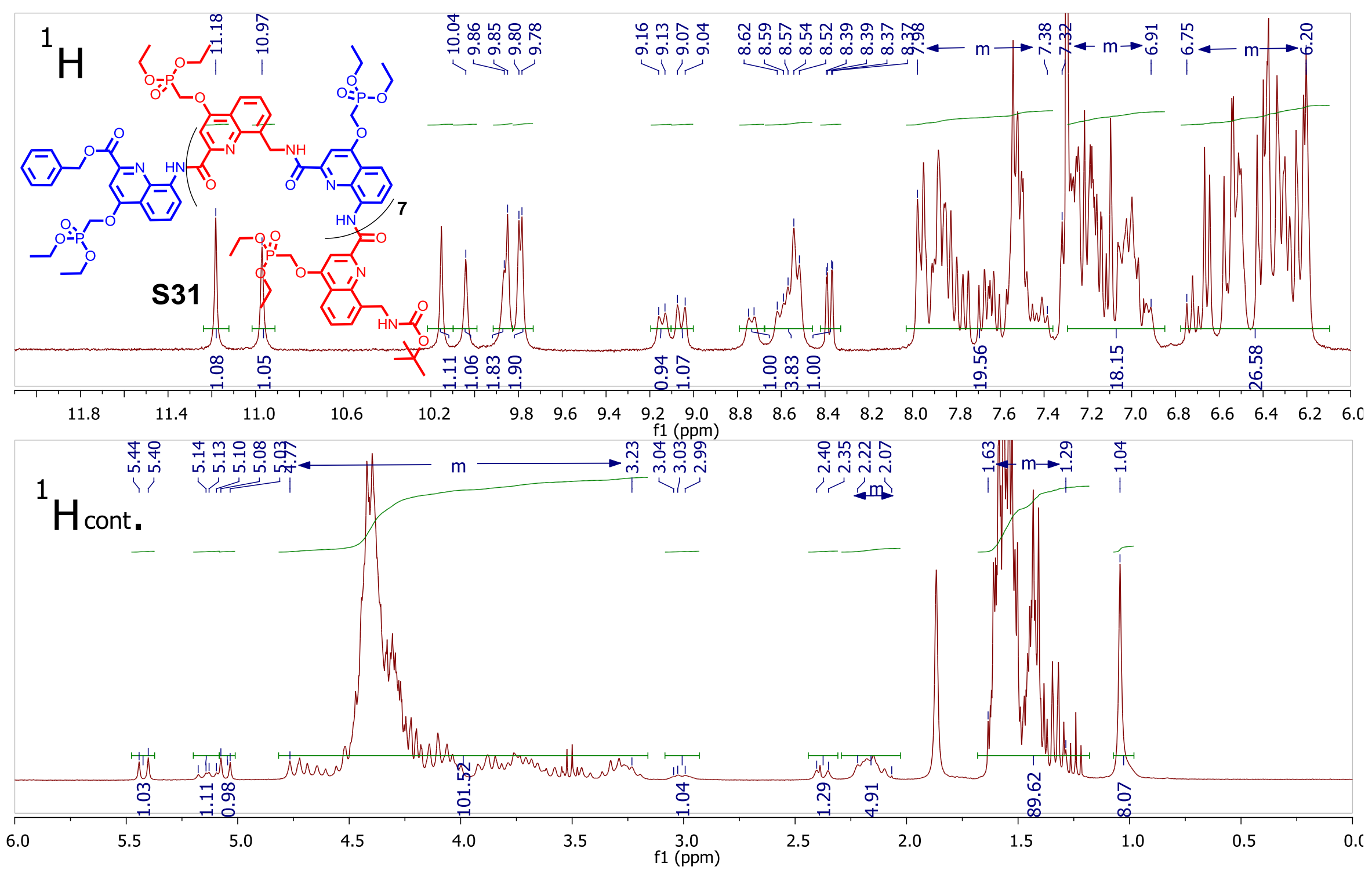


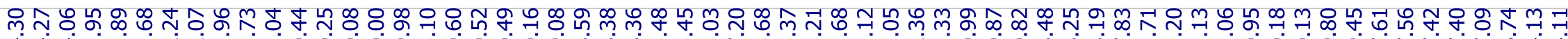
苛 它 苛

\section{S31 cont.}

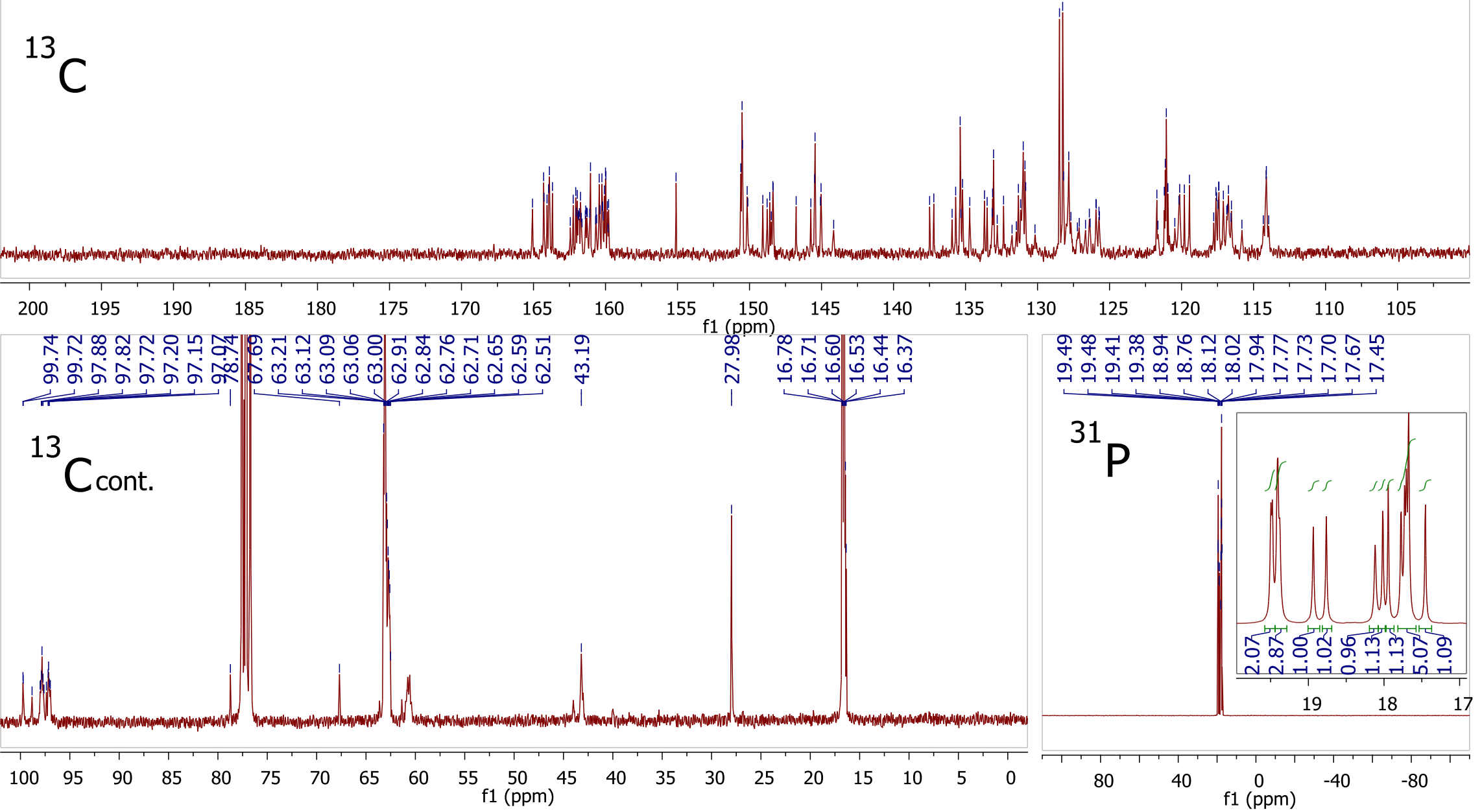



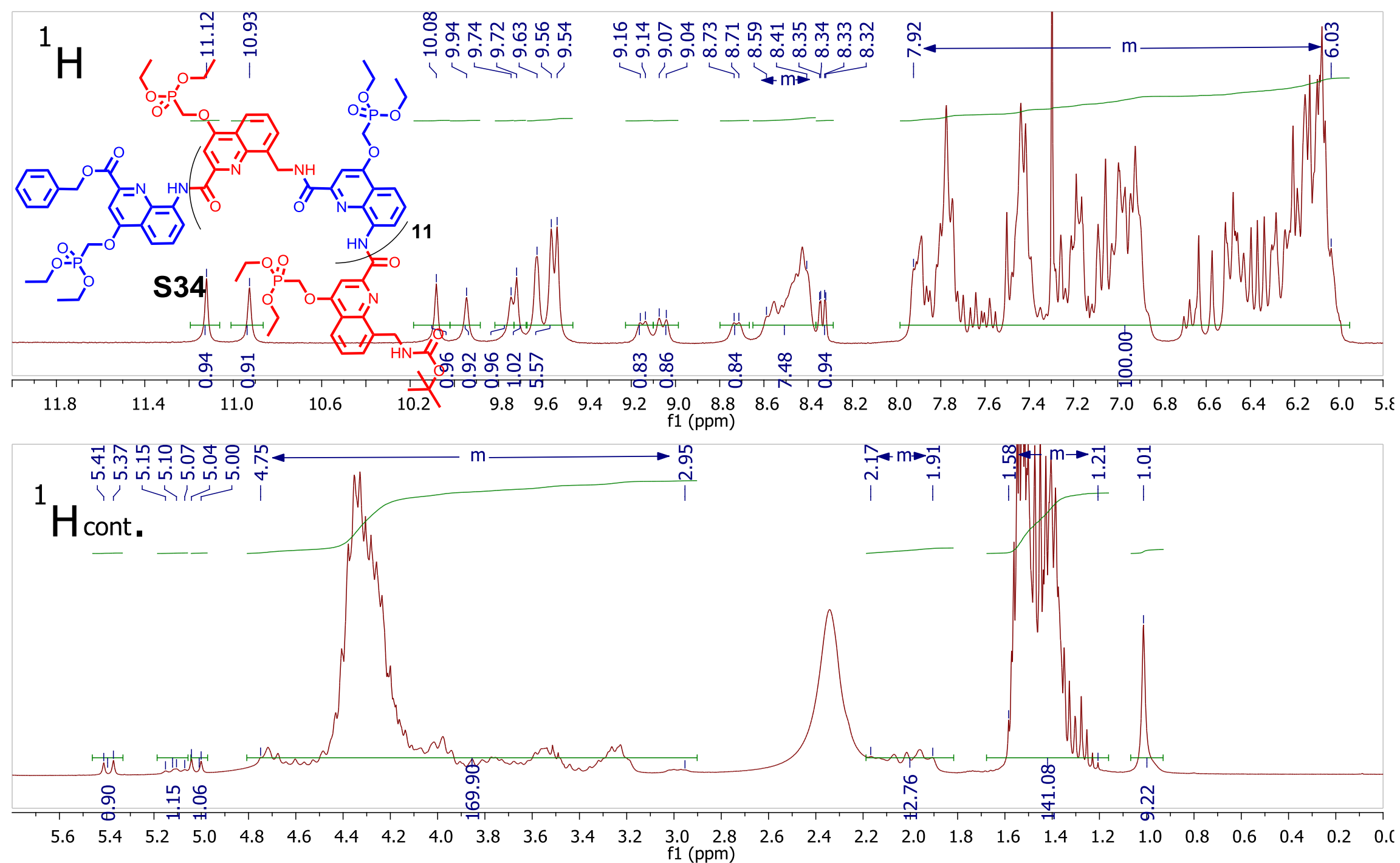

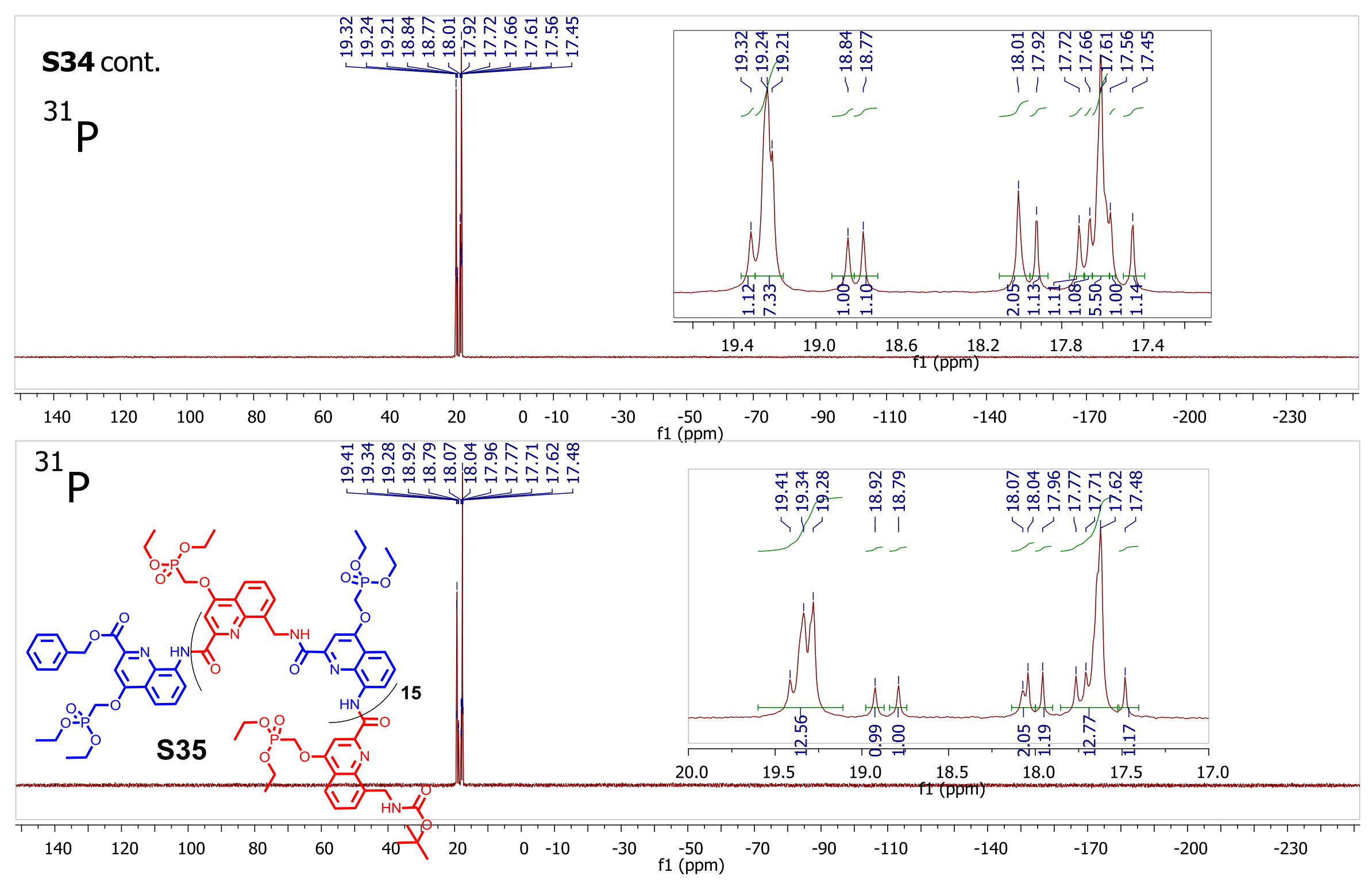

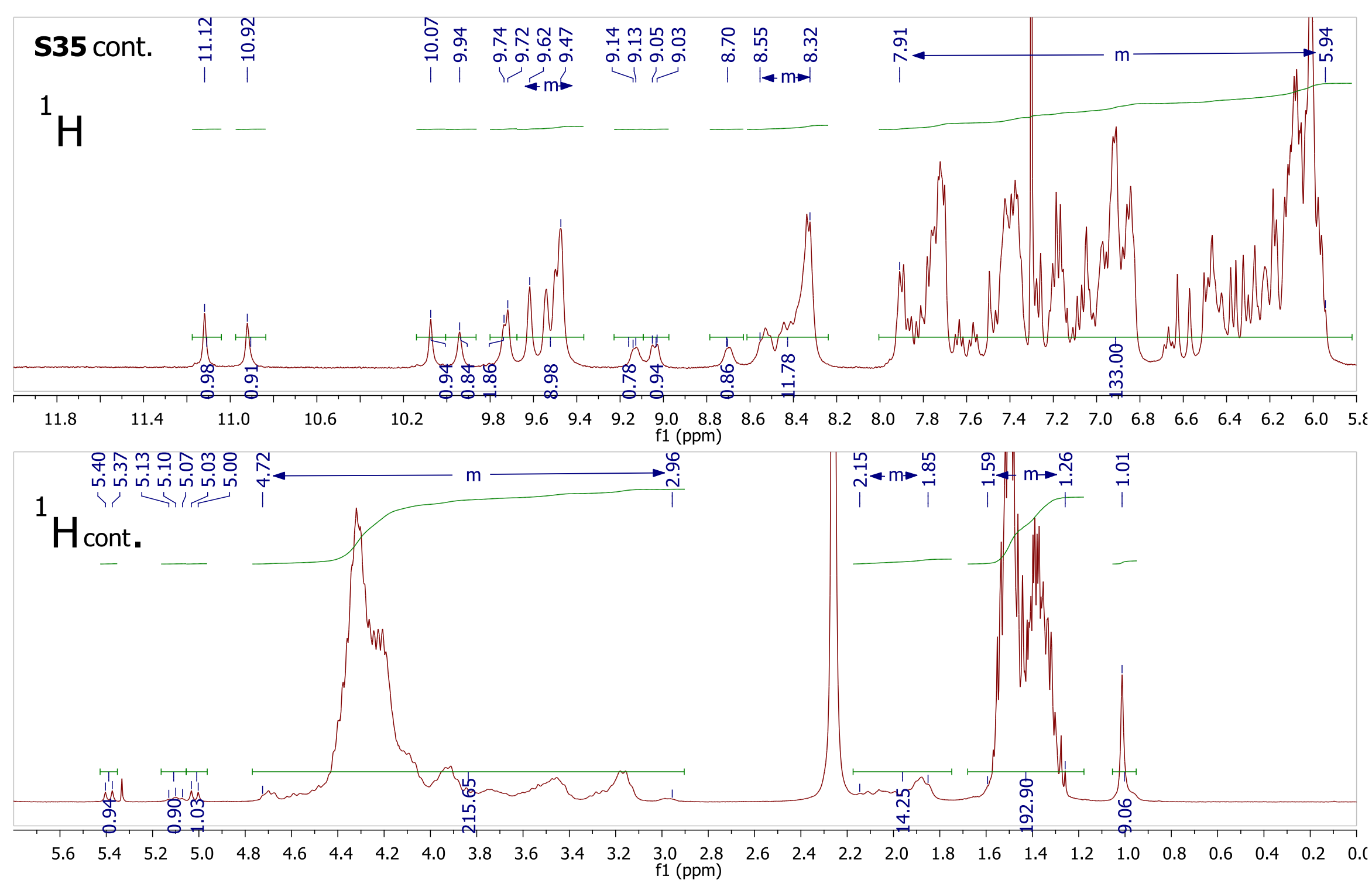


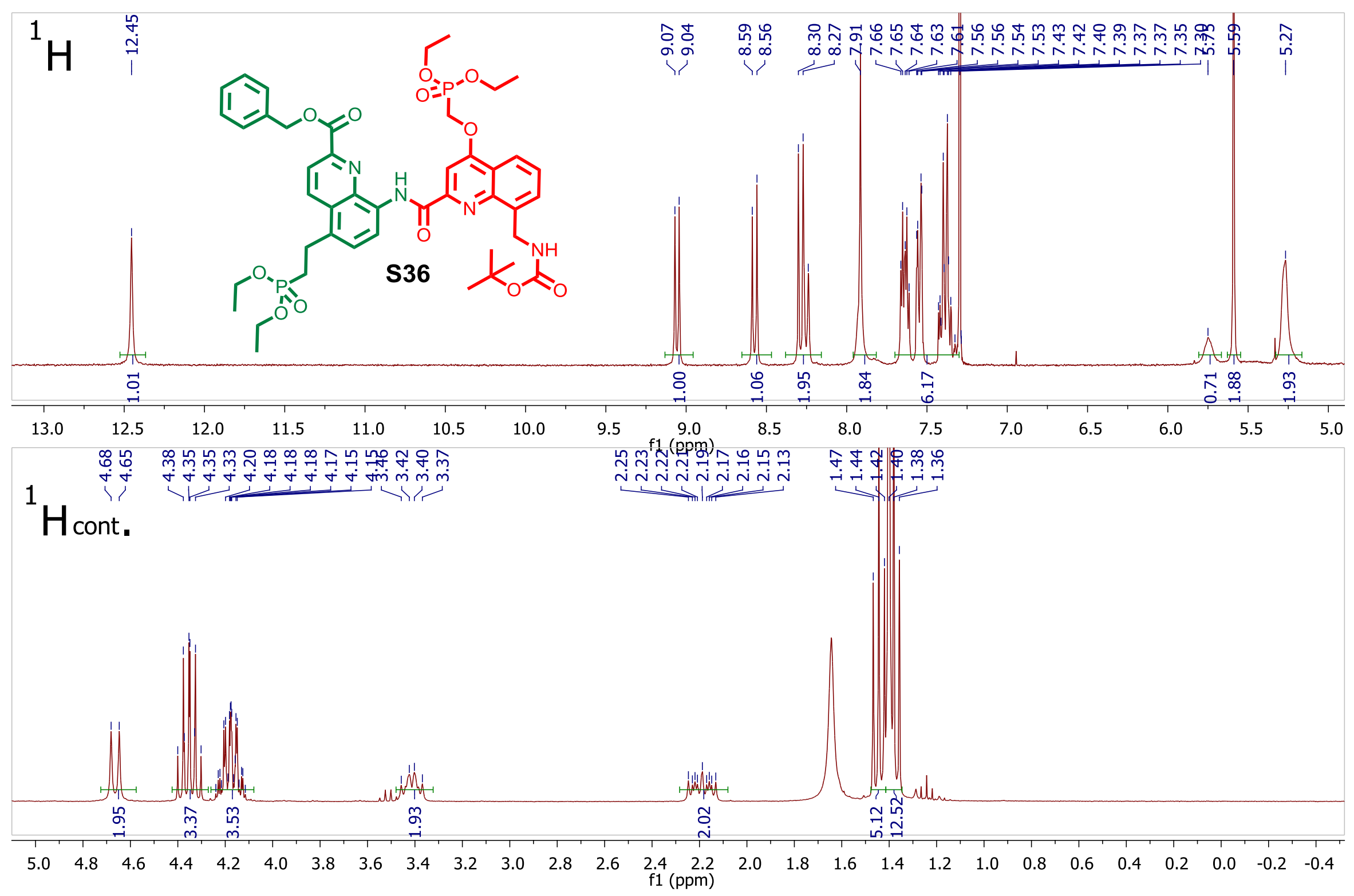




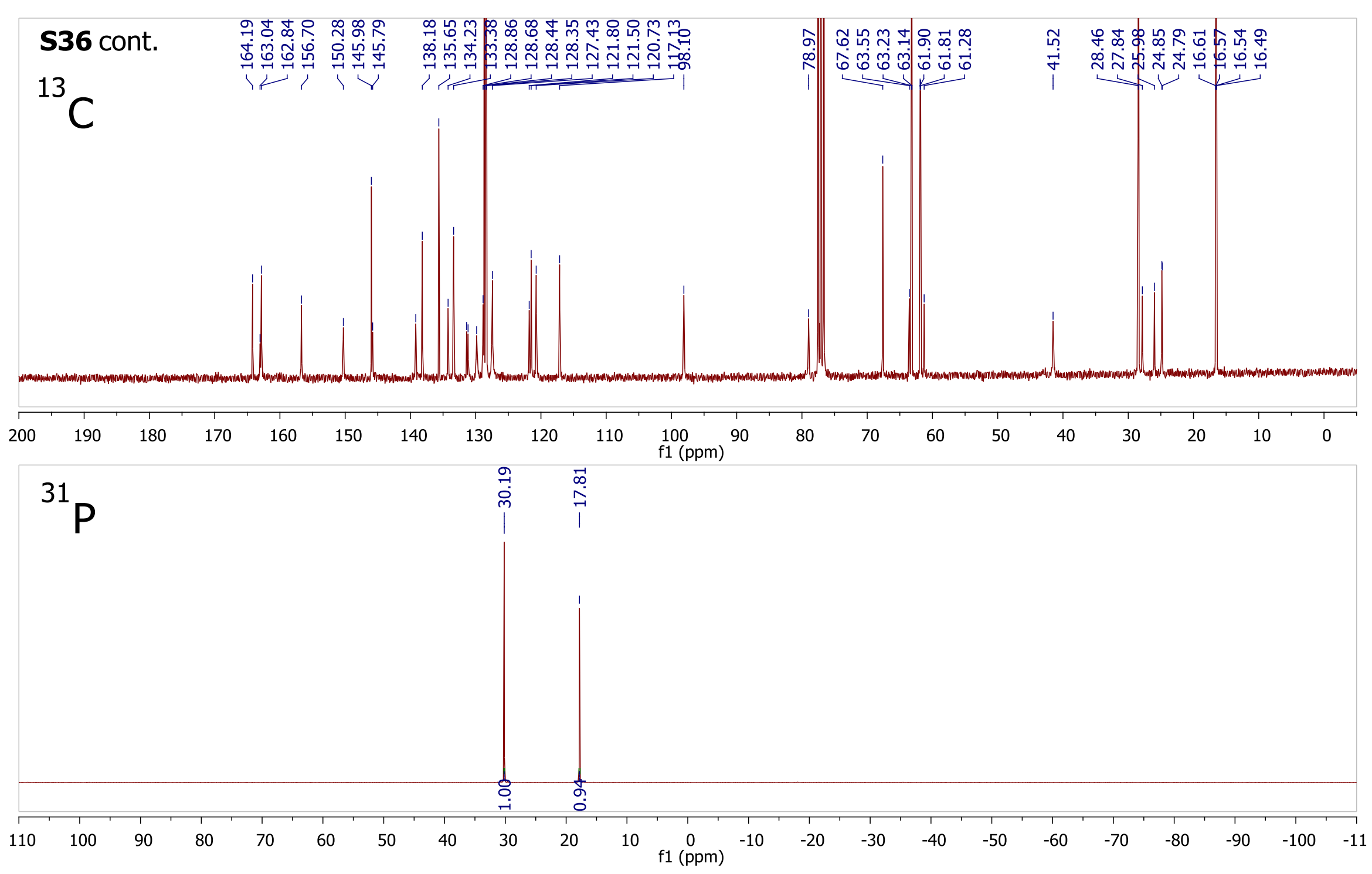



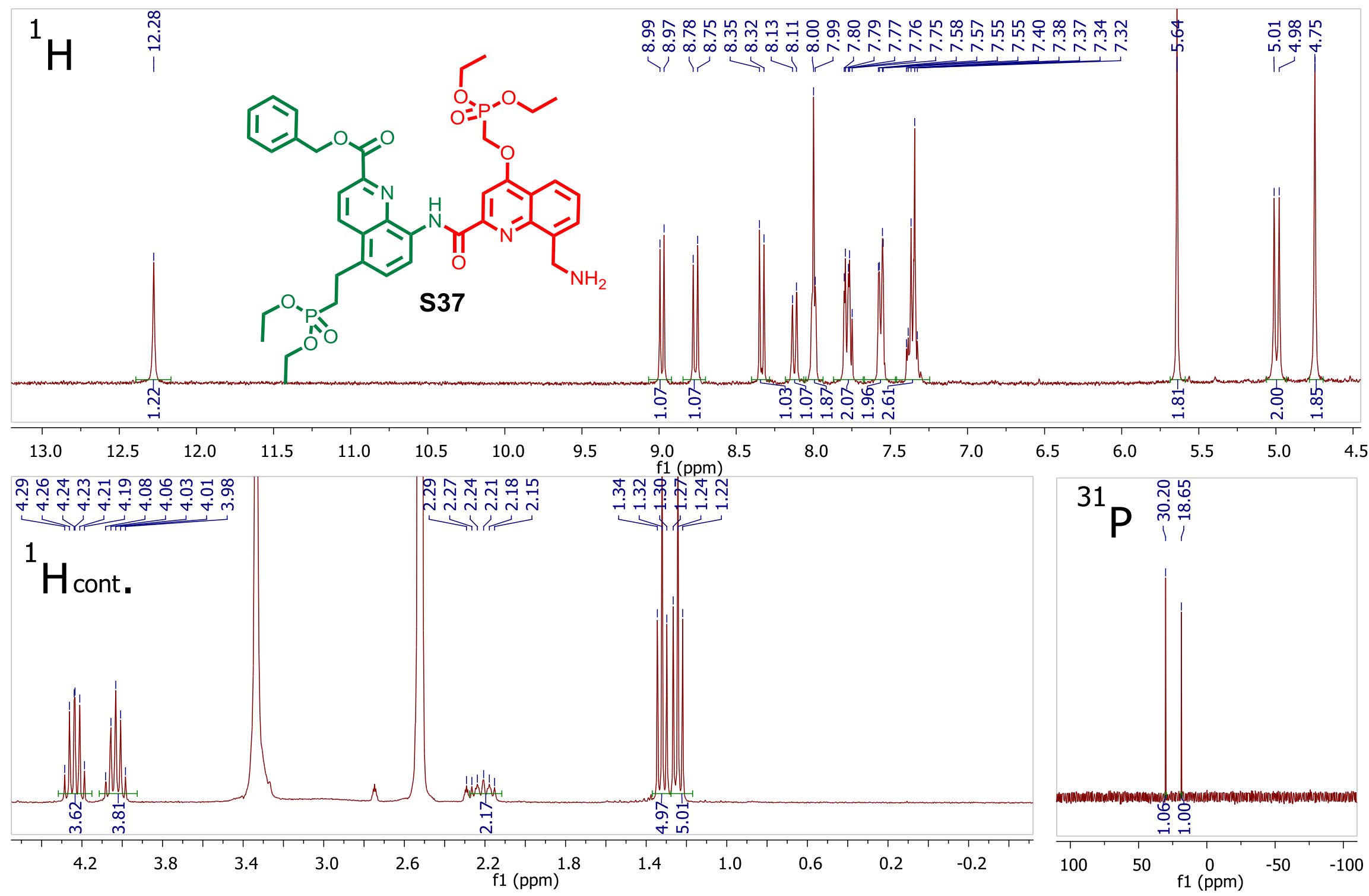


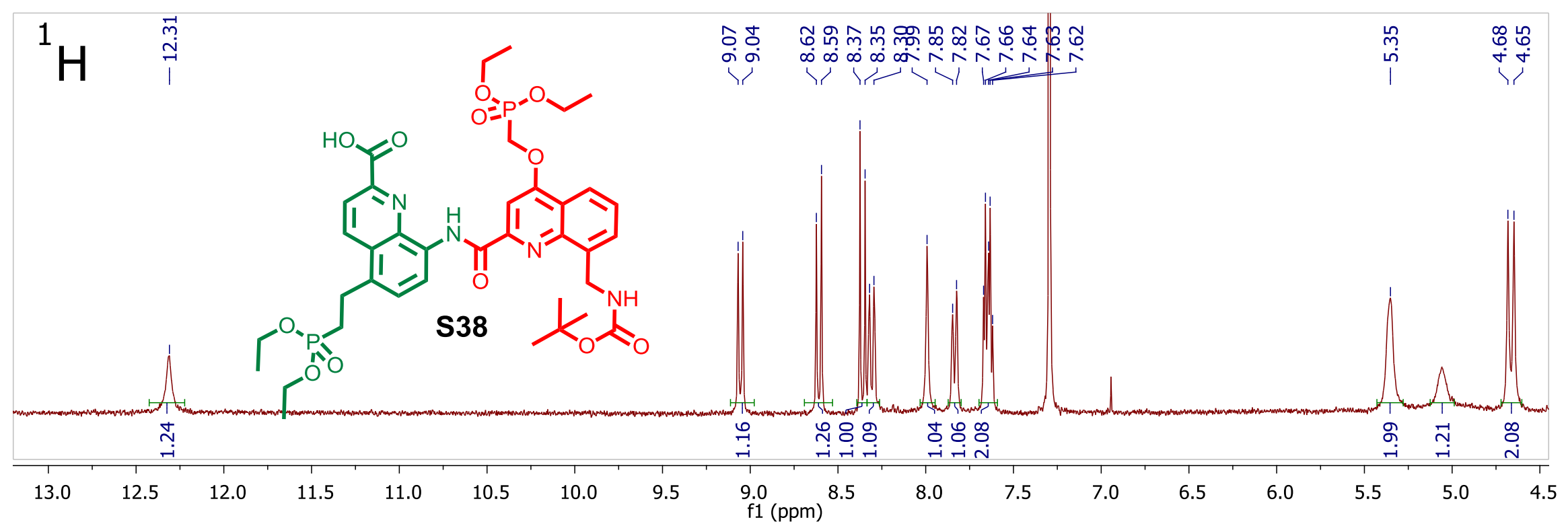

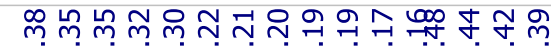

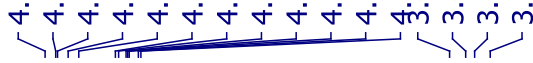

1

$\mathrm{H}_{\text {cont. }}$.

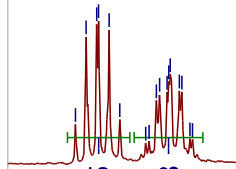

ก $\stackrel{\infty}{\text { ก }}$

$4.4 \quad 4.2$

$4.0 \quad 3.8$

的的

物政

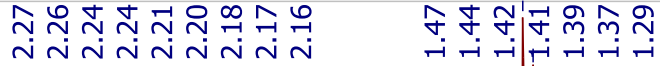

-

$\longrightarrow$

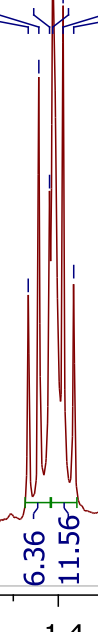
$2.2 \underset{f 1(p p m)}{2.0}$

$\begin{array}{lllllll}6 & 3.4 & 3.2 & 3.0 & 2.8 & 2.6 & 2.4\end{array}$ 


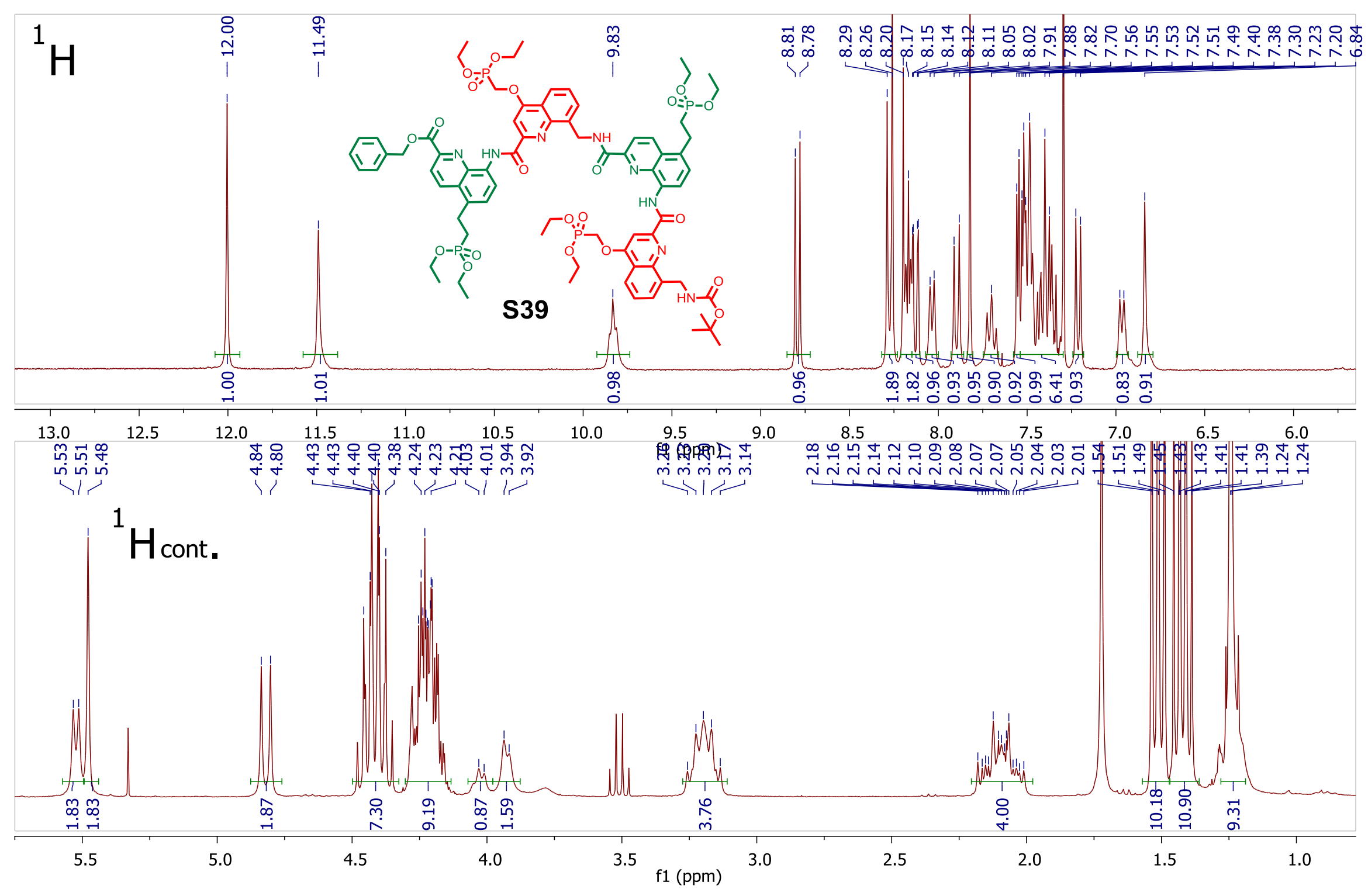



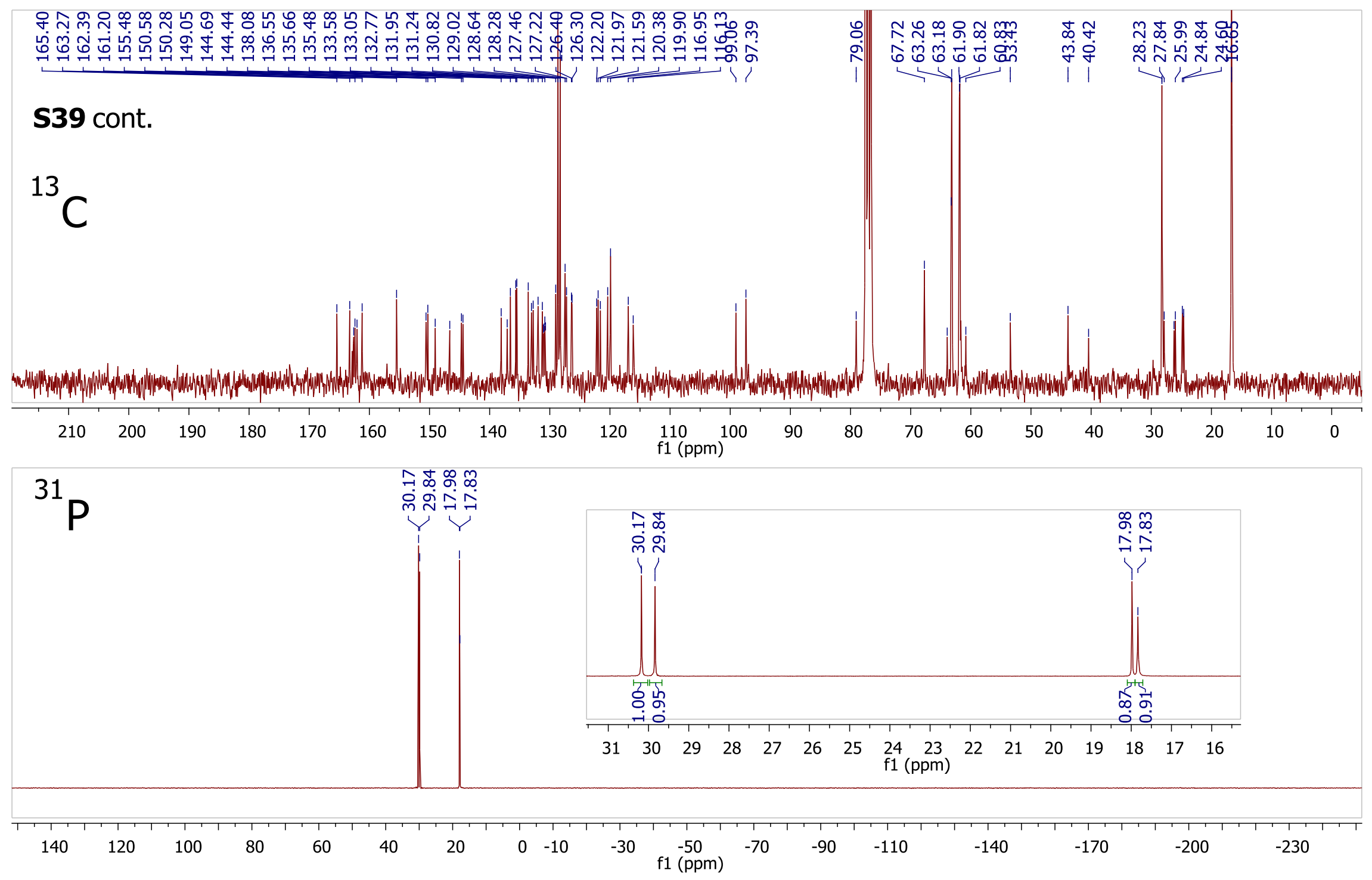


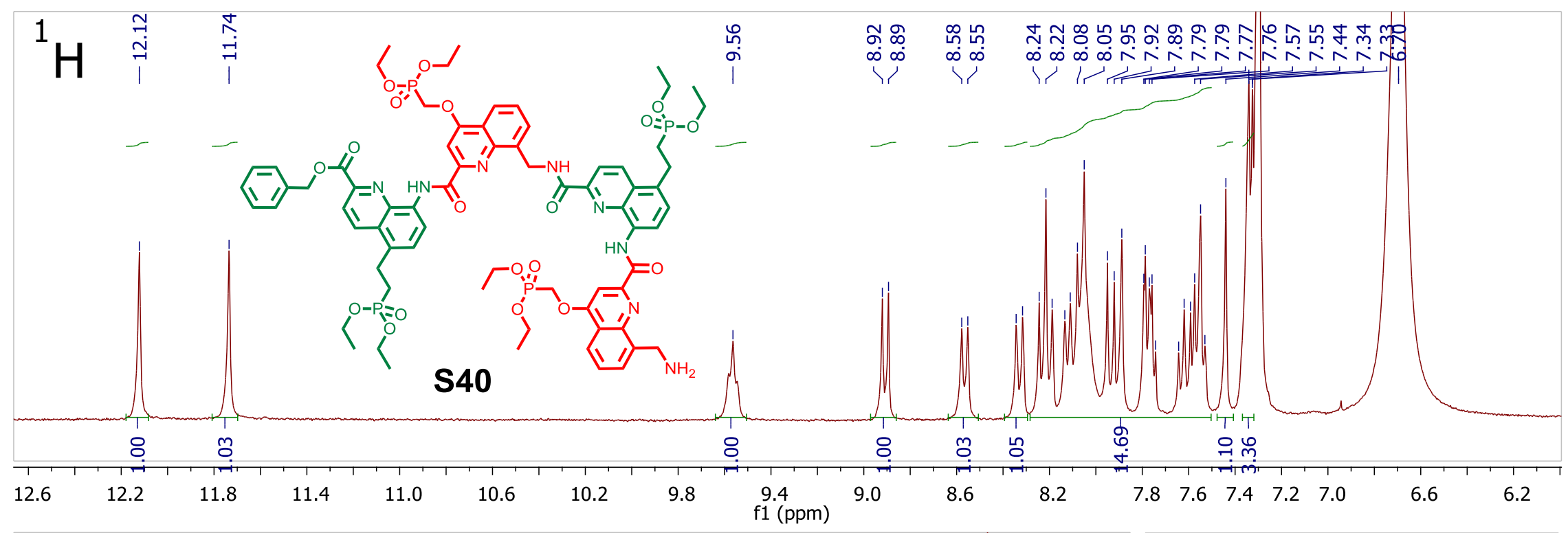

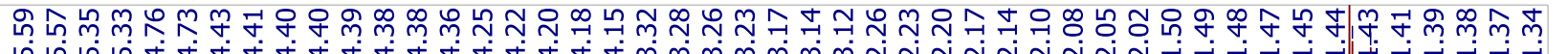

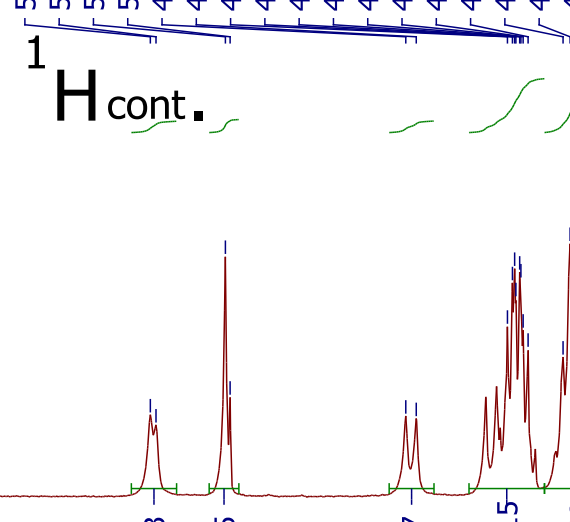

$\stackrel{m}{\rightarrow}$ ๆ ๆ
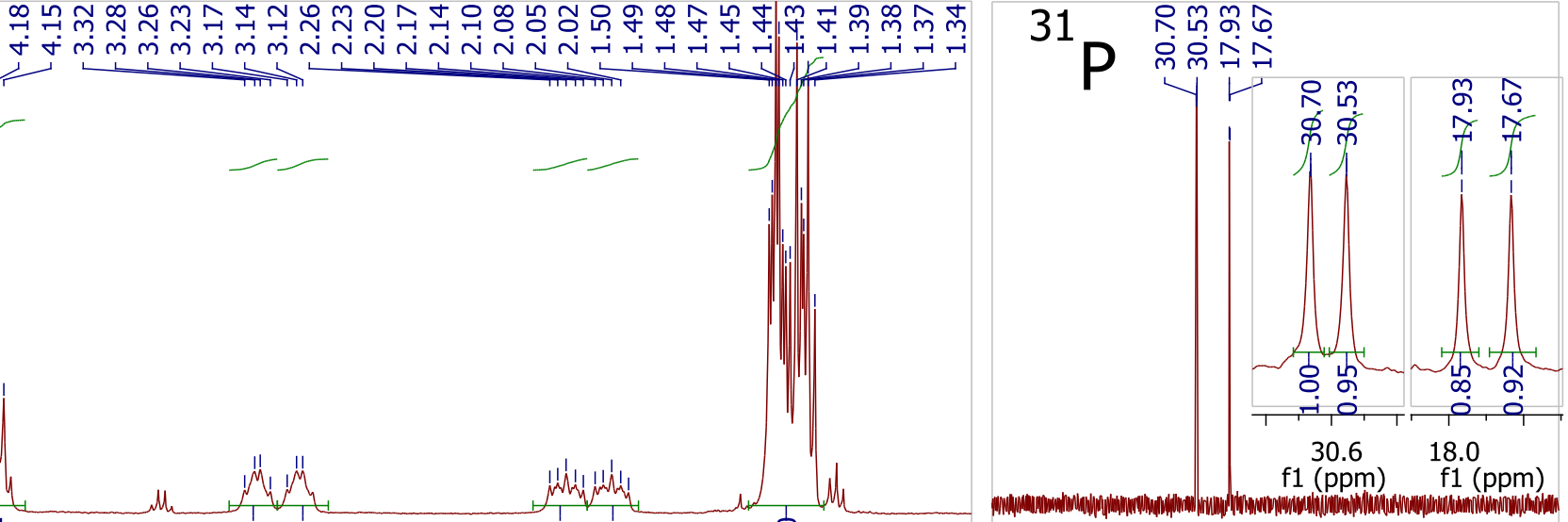

5.8
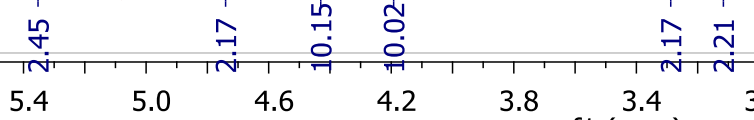

whink

กิ

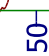

용

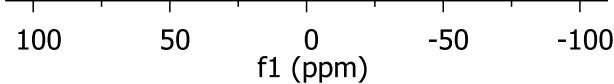




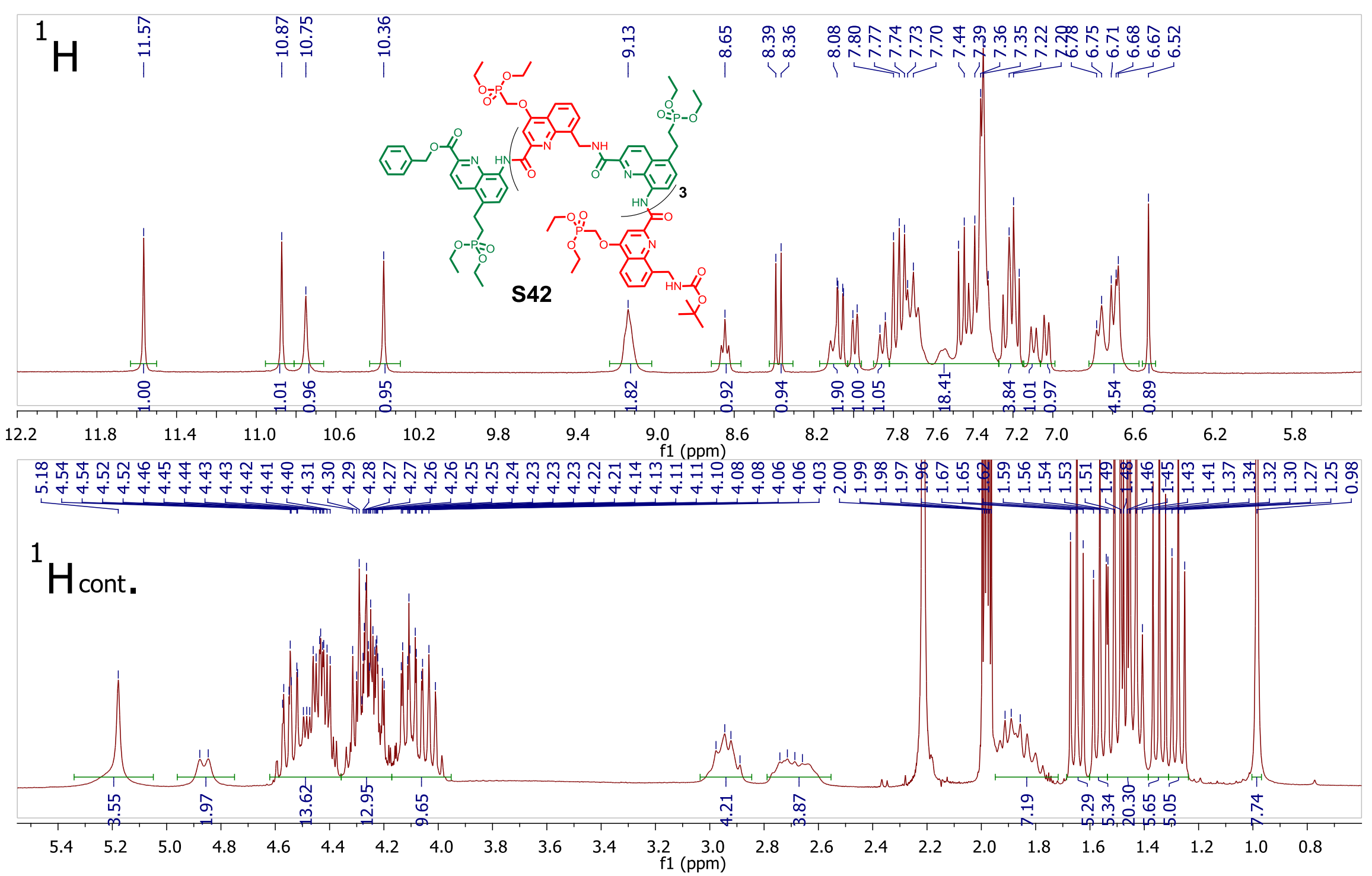




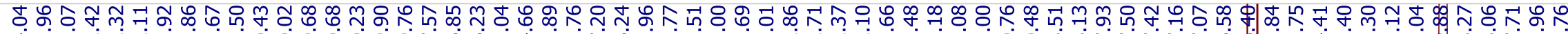

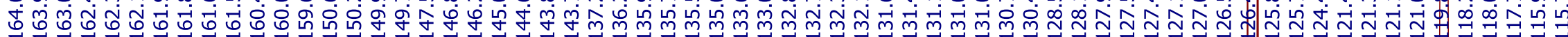

\section{S42 cont.}

${ }^{13} \mathrm{C}$

\begin{tabular}{|c|c|c|c|c|c|c|c|c|c|c|c|c|c|c|c|c|c|}
\hline & 1 & 1 & 1 & 1 & 1 & 1 & 1 & 1 & 115 & 1 & 1 & 11 & 11 & & 1 & 1 & \\
\hline & 195 & 190 & 185 & 180 & 175 & 170 & 165 & 160 & 155 & 150 & 145 & 140 & 135 & 130 & 125 & 120 & 115 \\
\hline
\end{tabular}

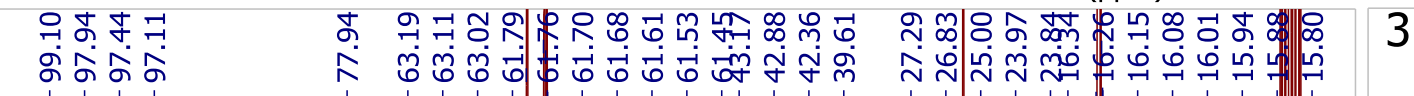

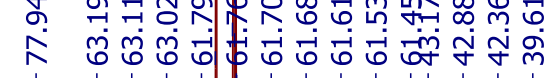

${ }^{13} \mathrm{C}_{\text {cont. }}$

14

31 P

西

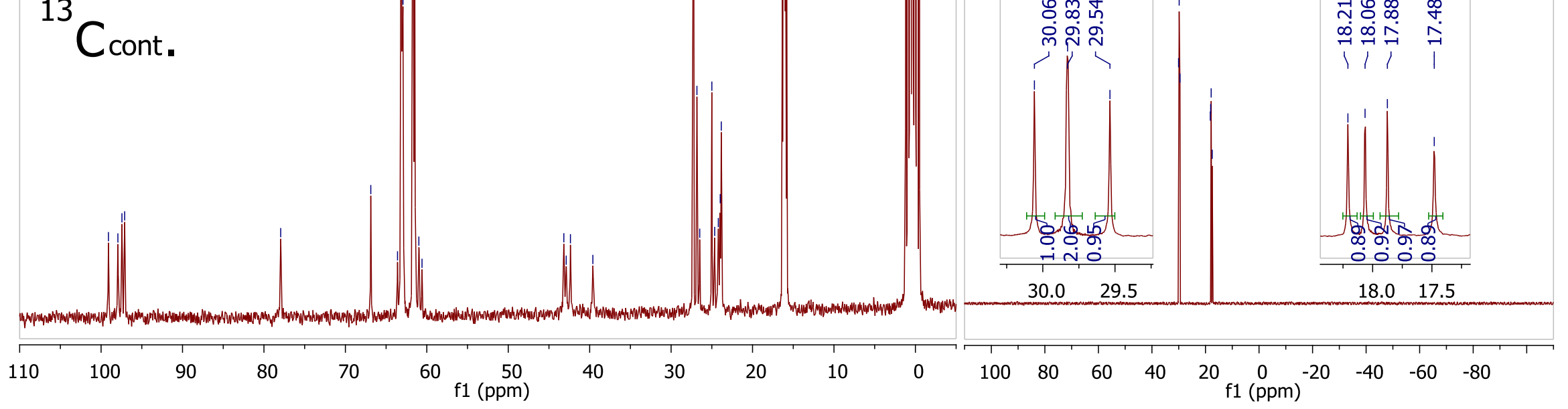



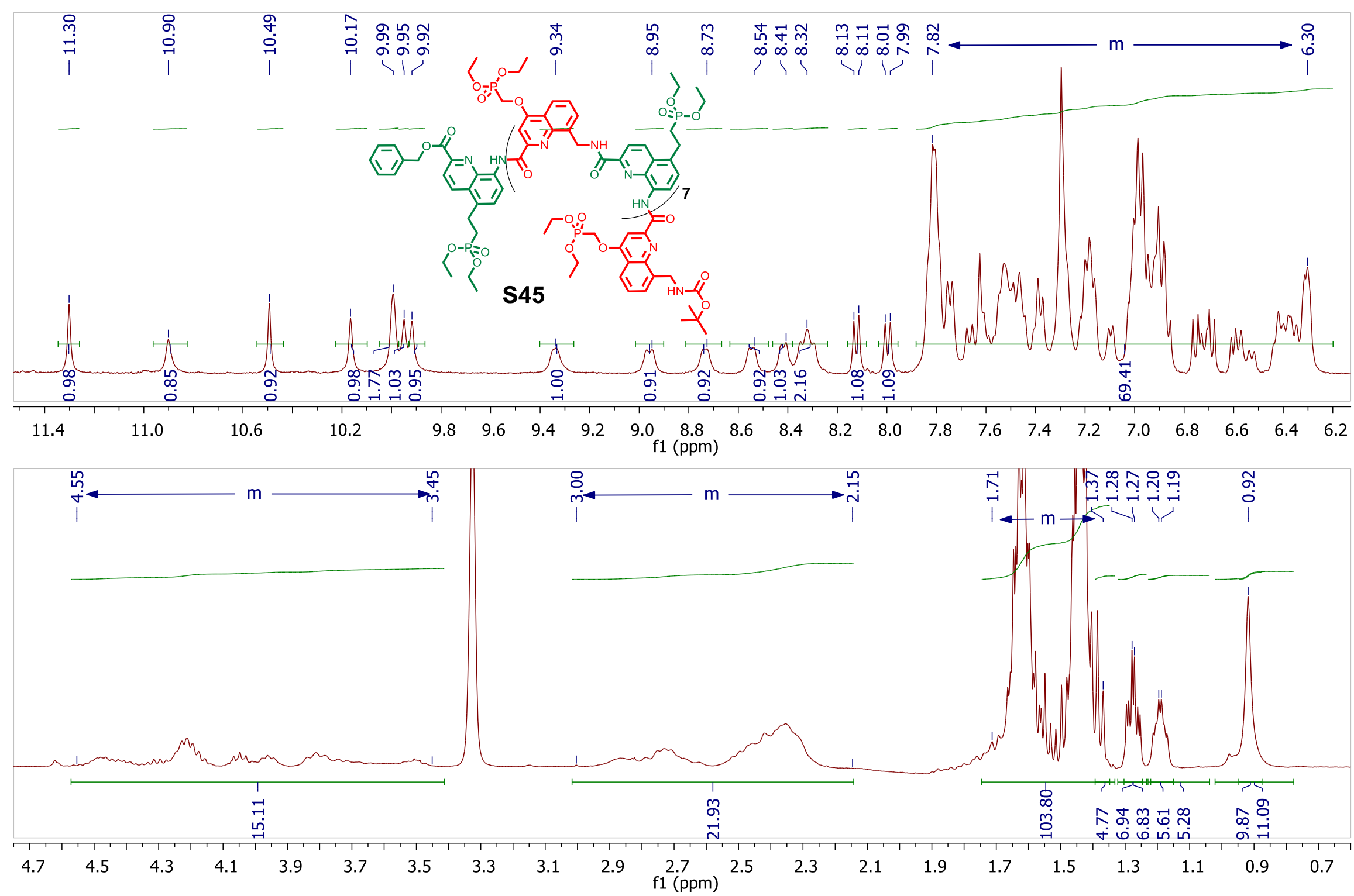


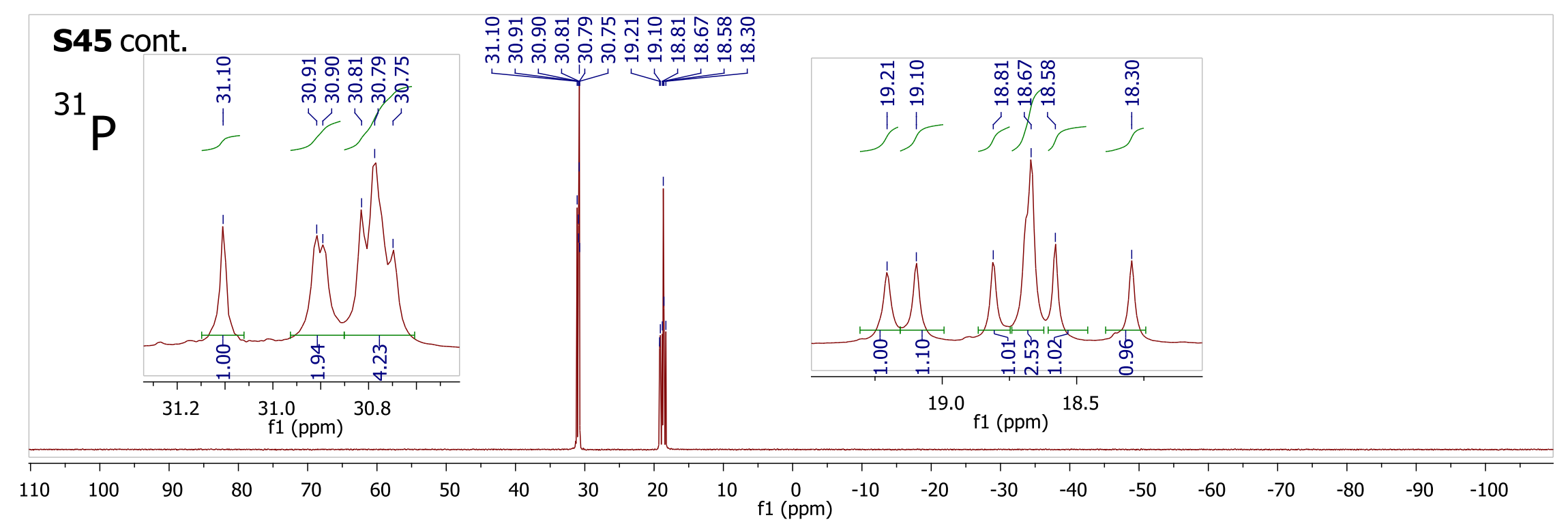



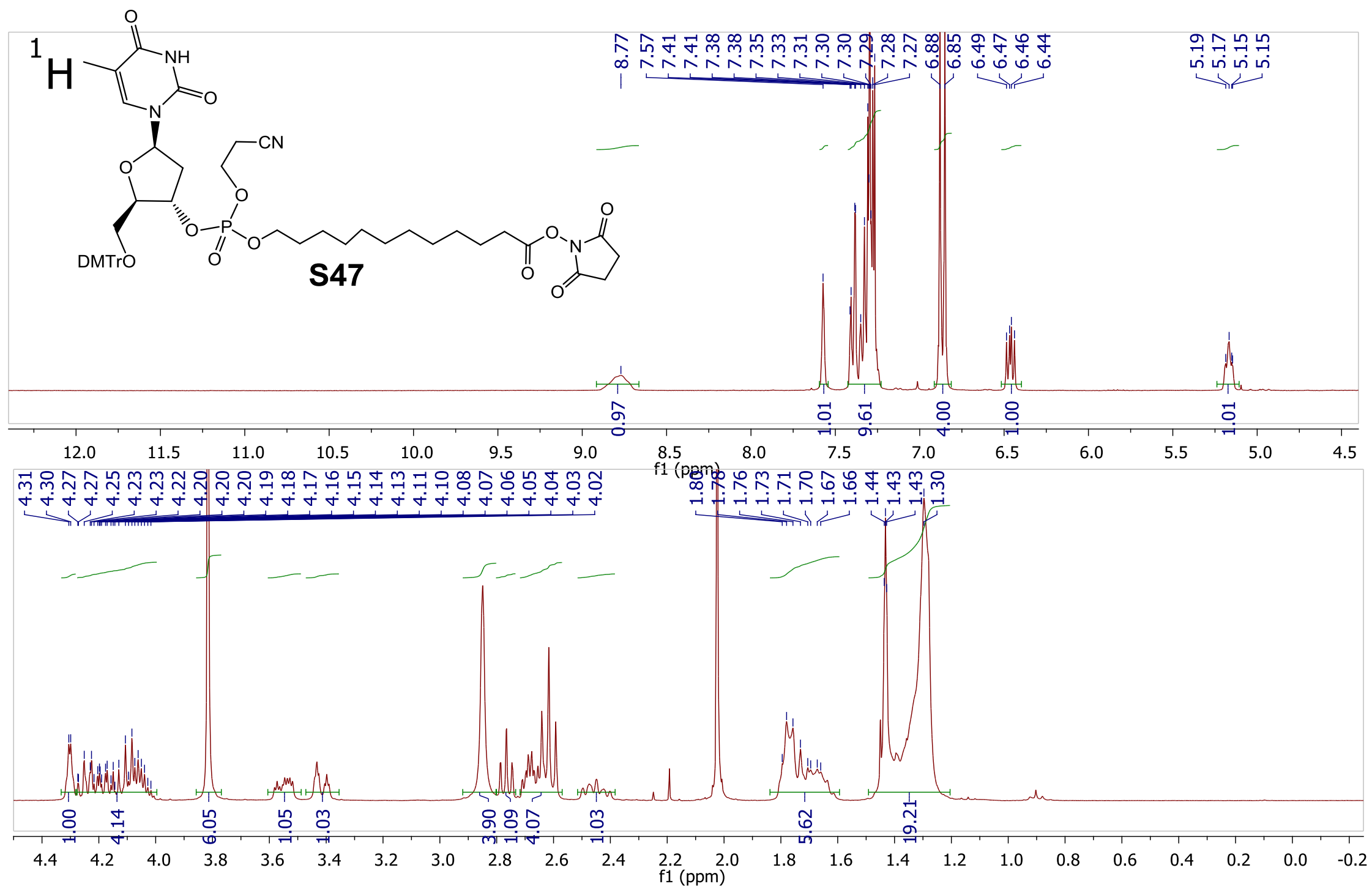


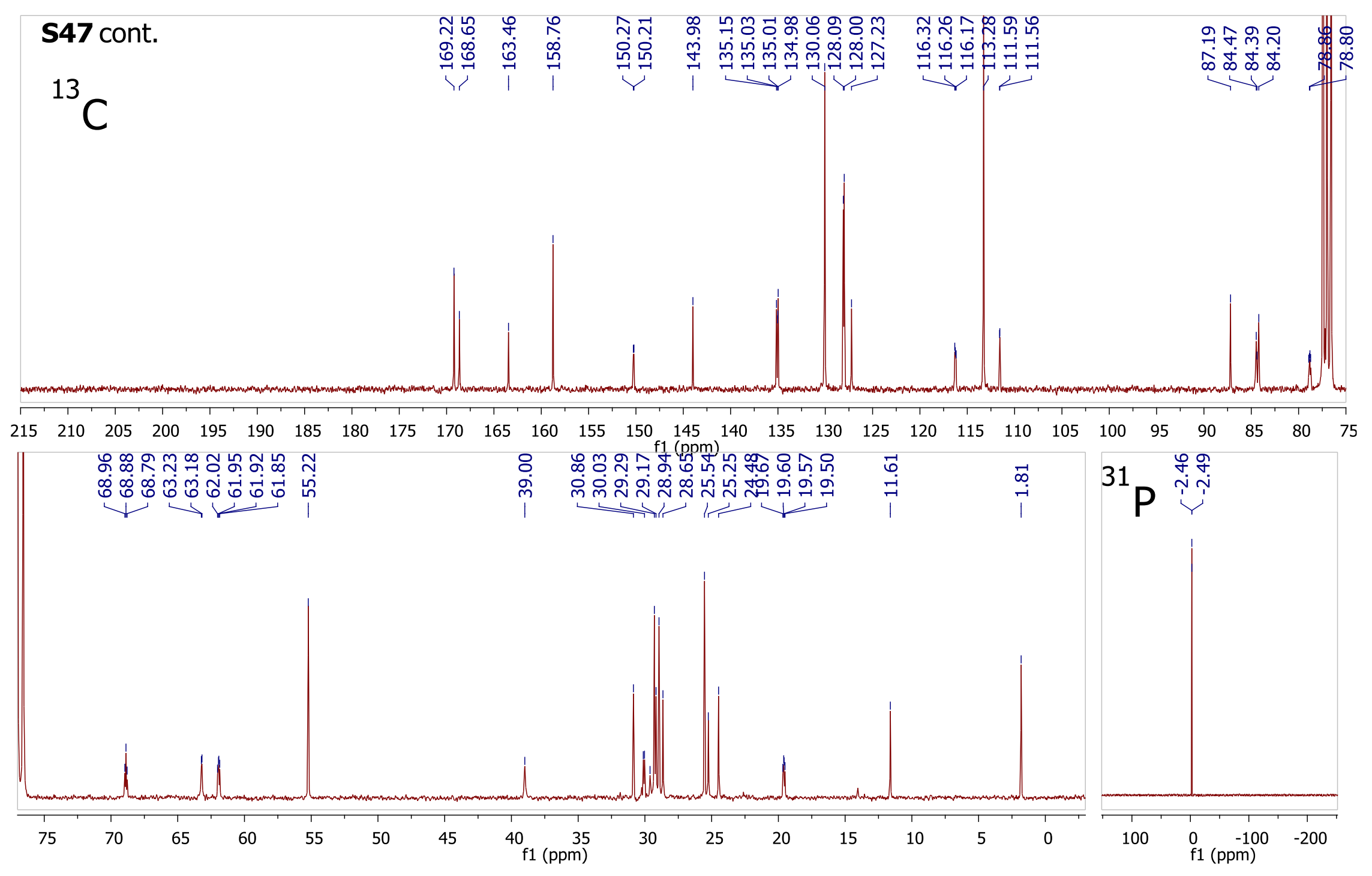



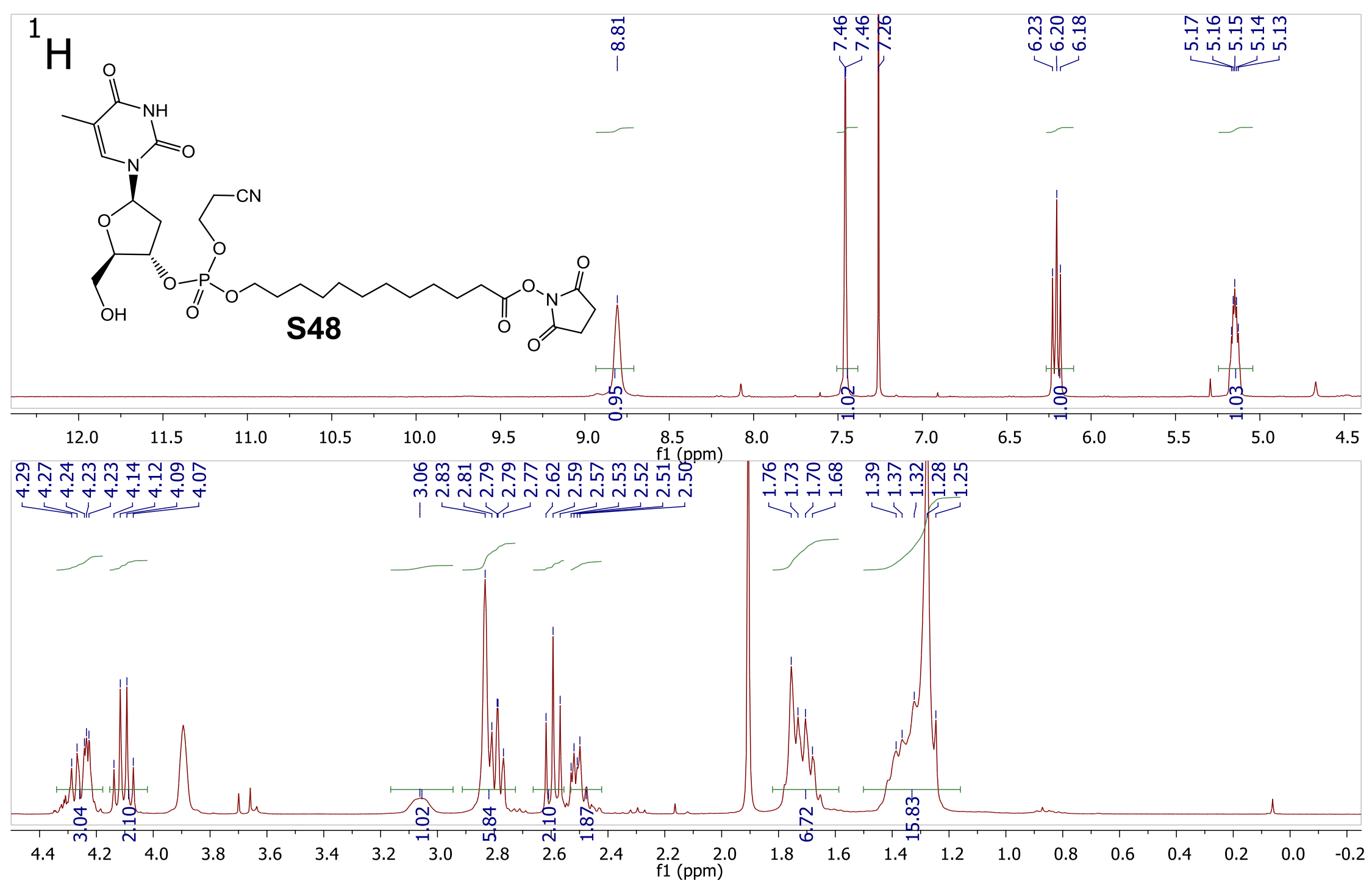


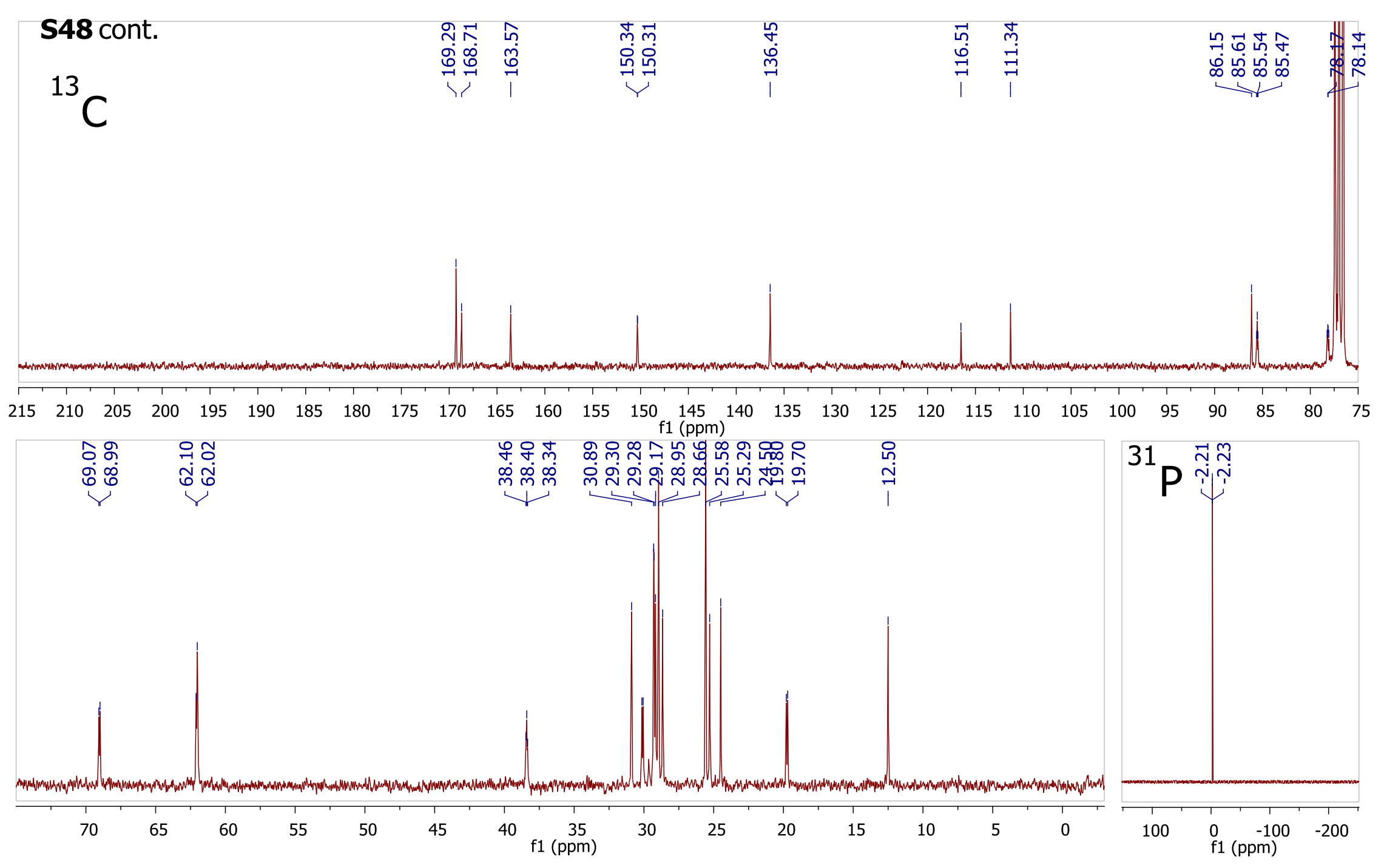




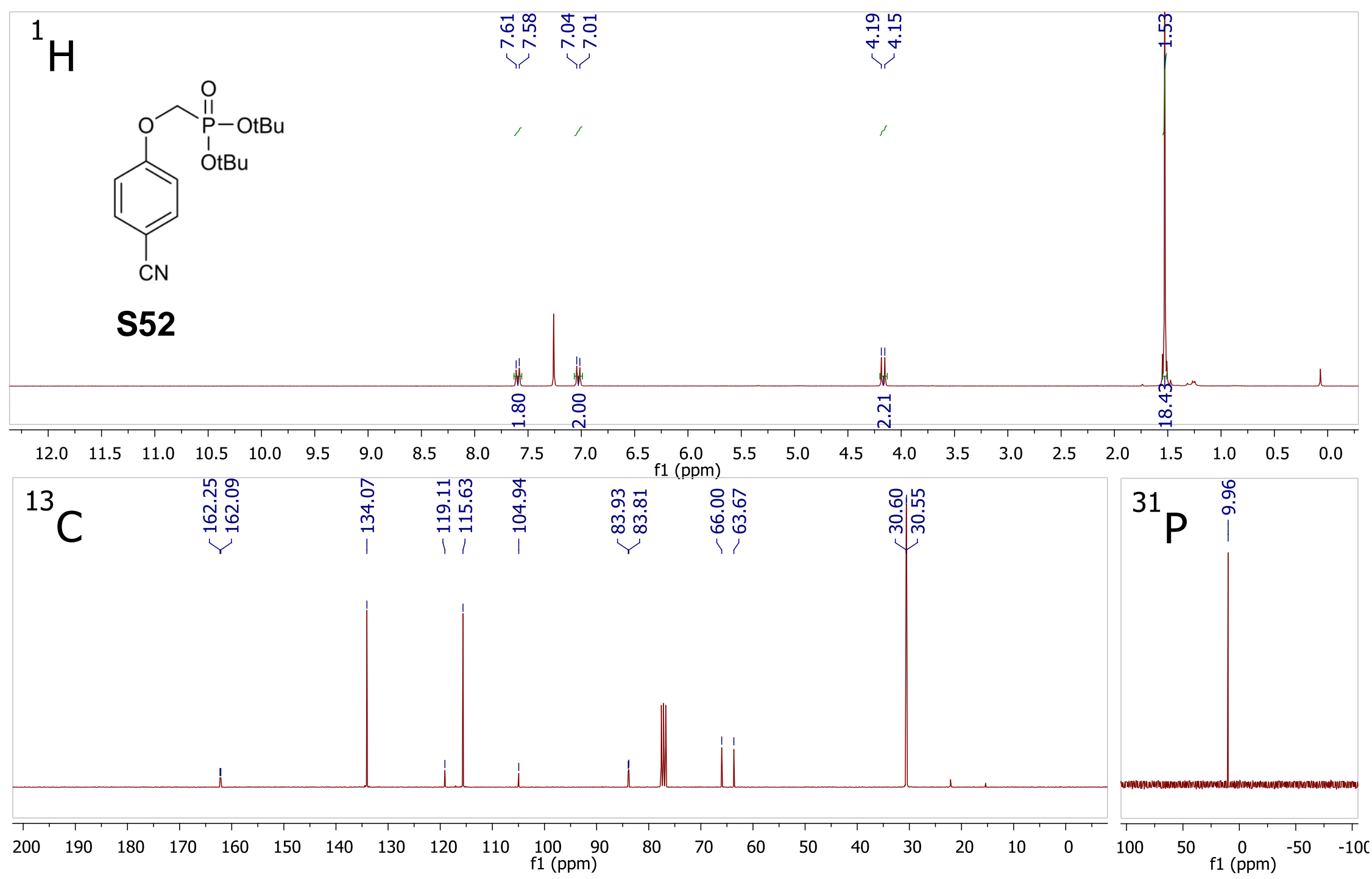




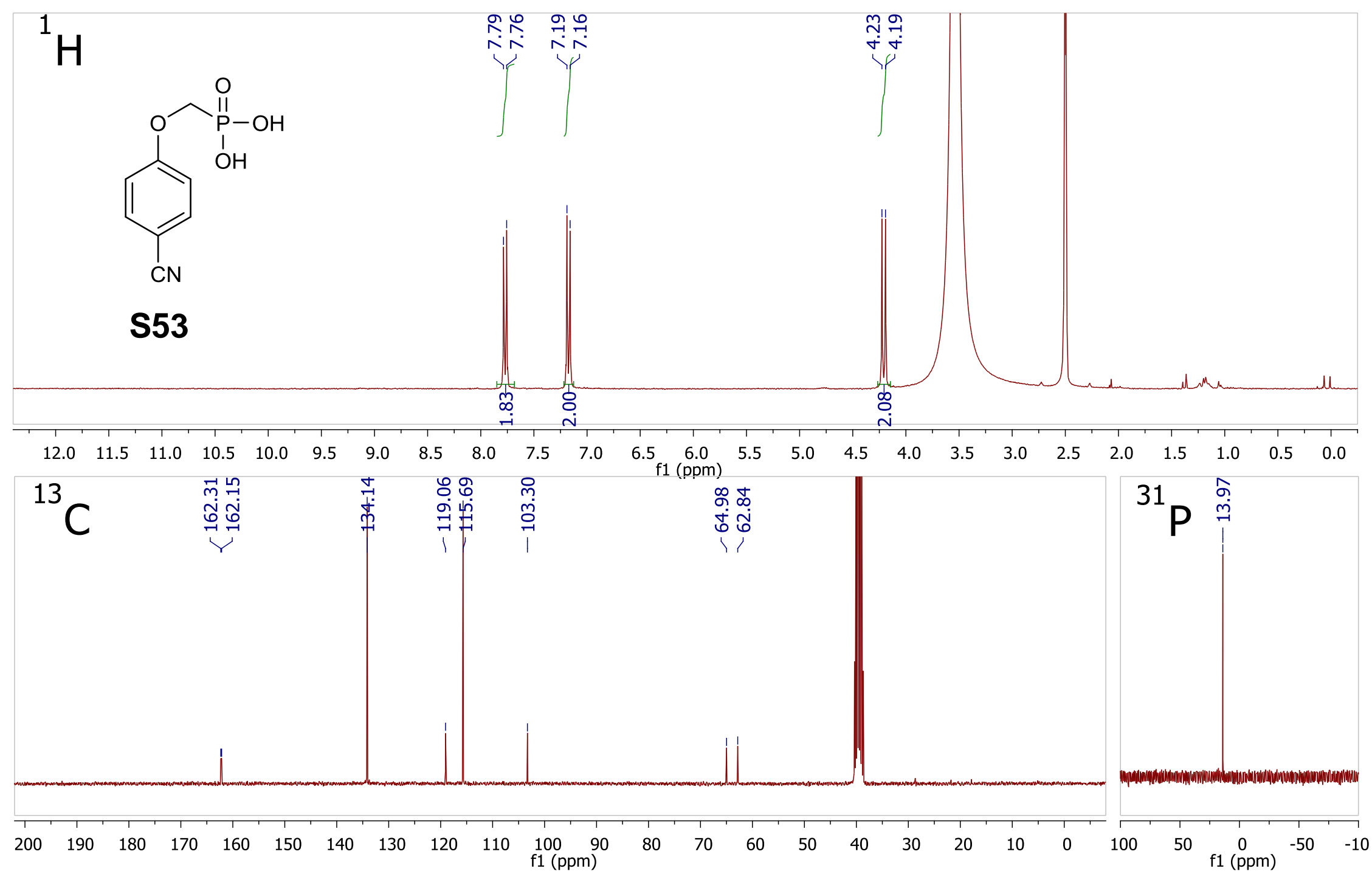



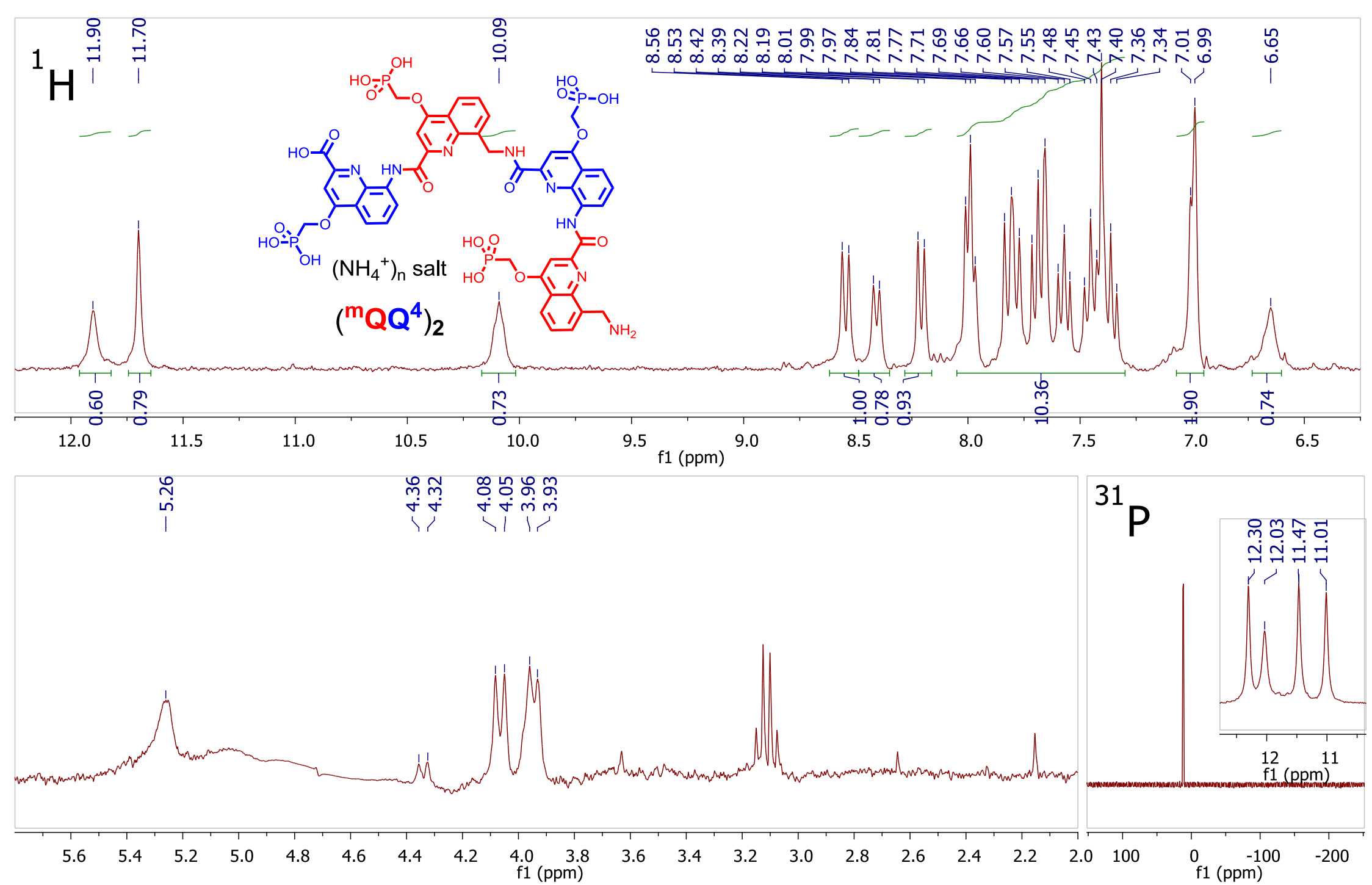


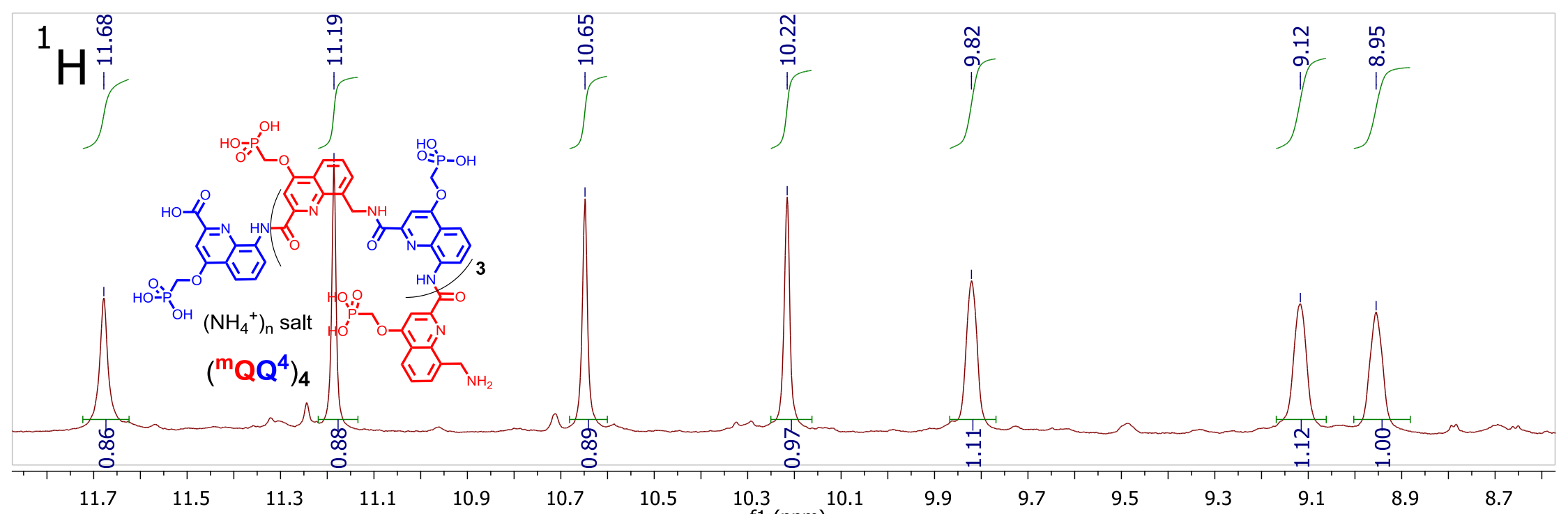

ஜొ

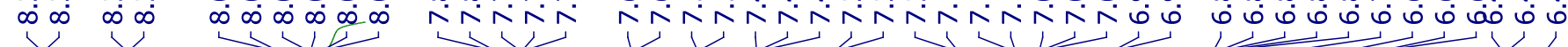
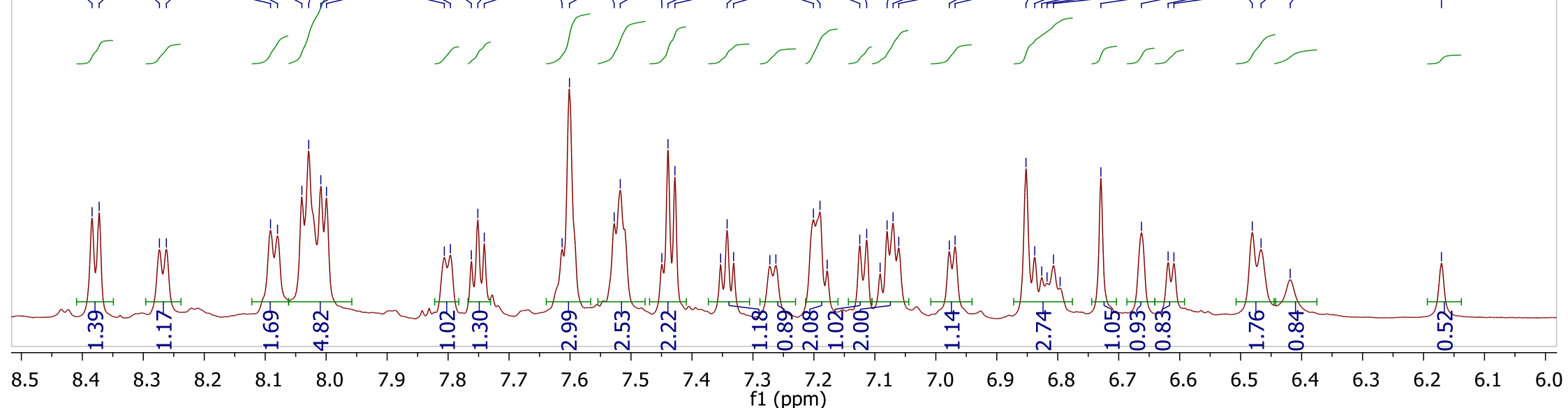


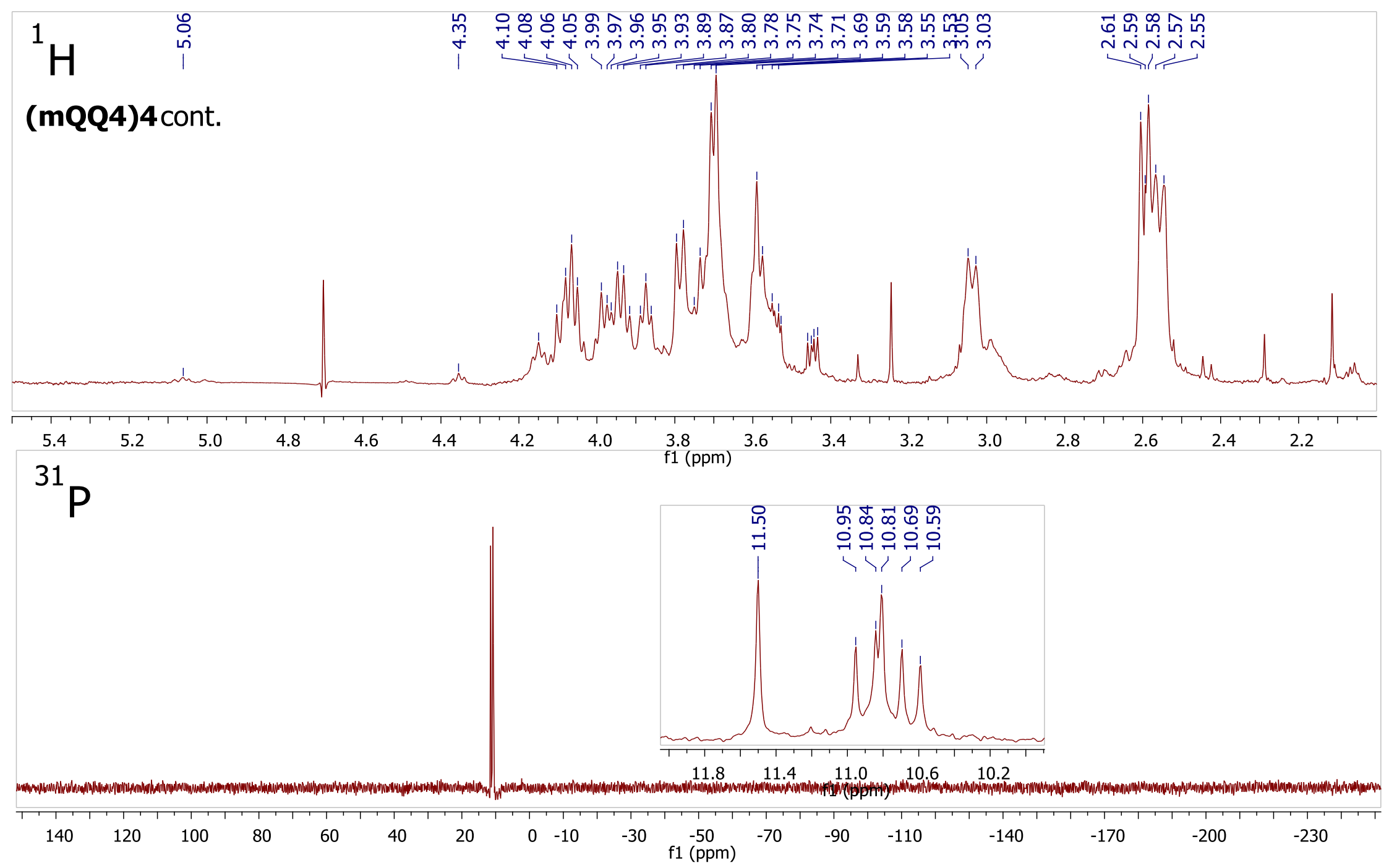




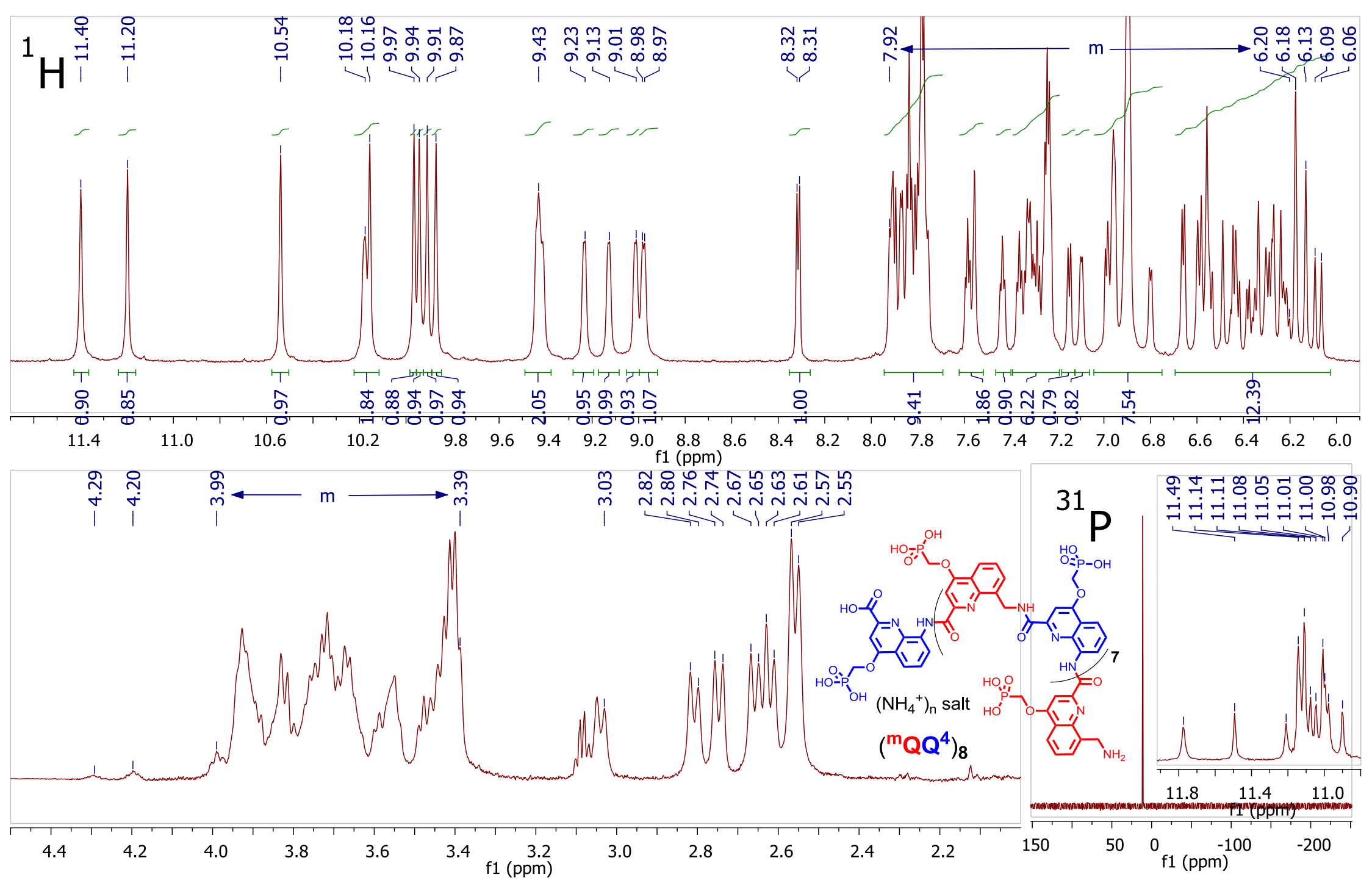




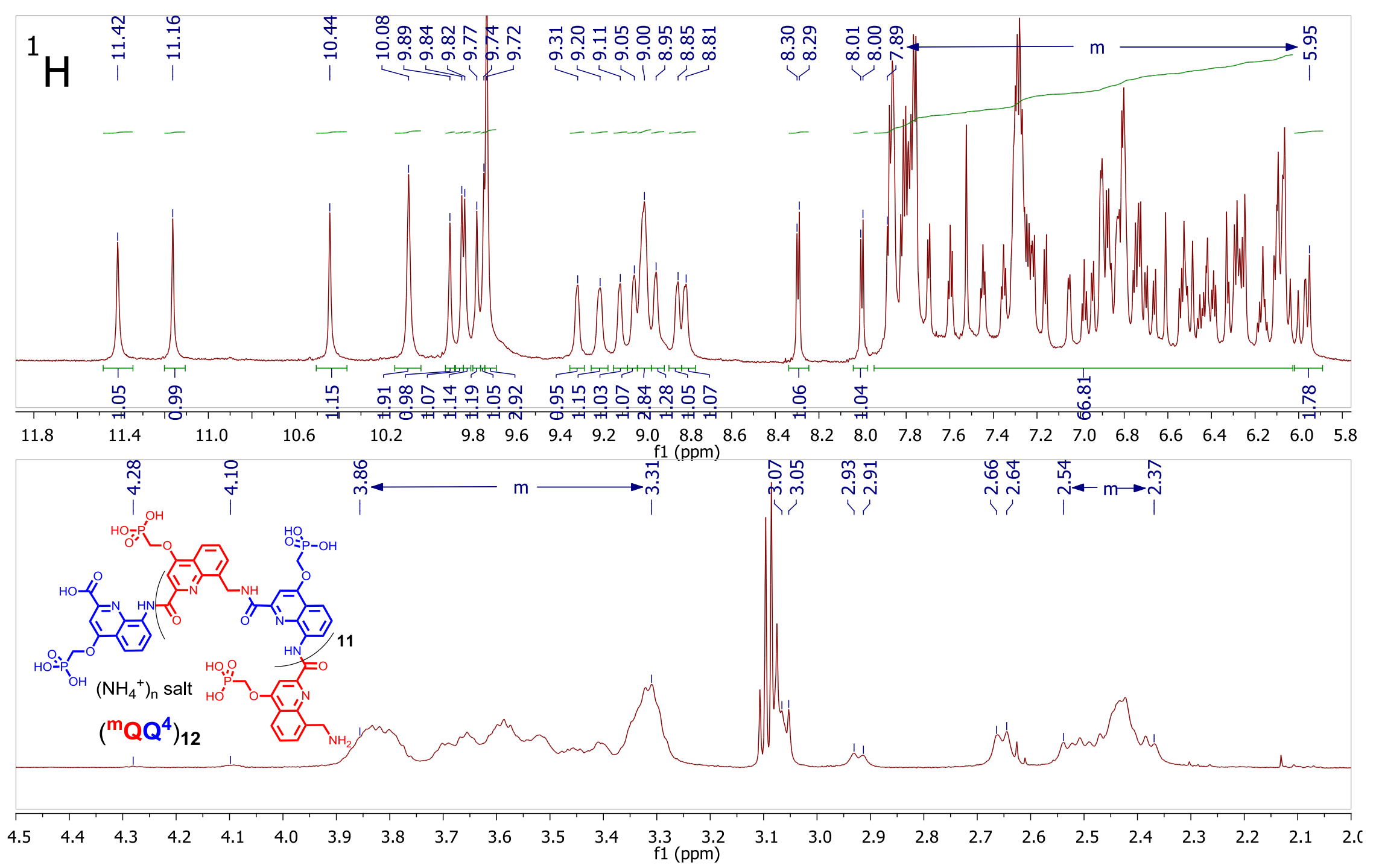




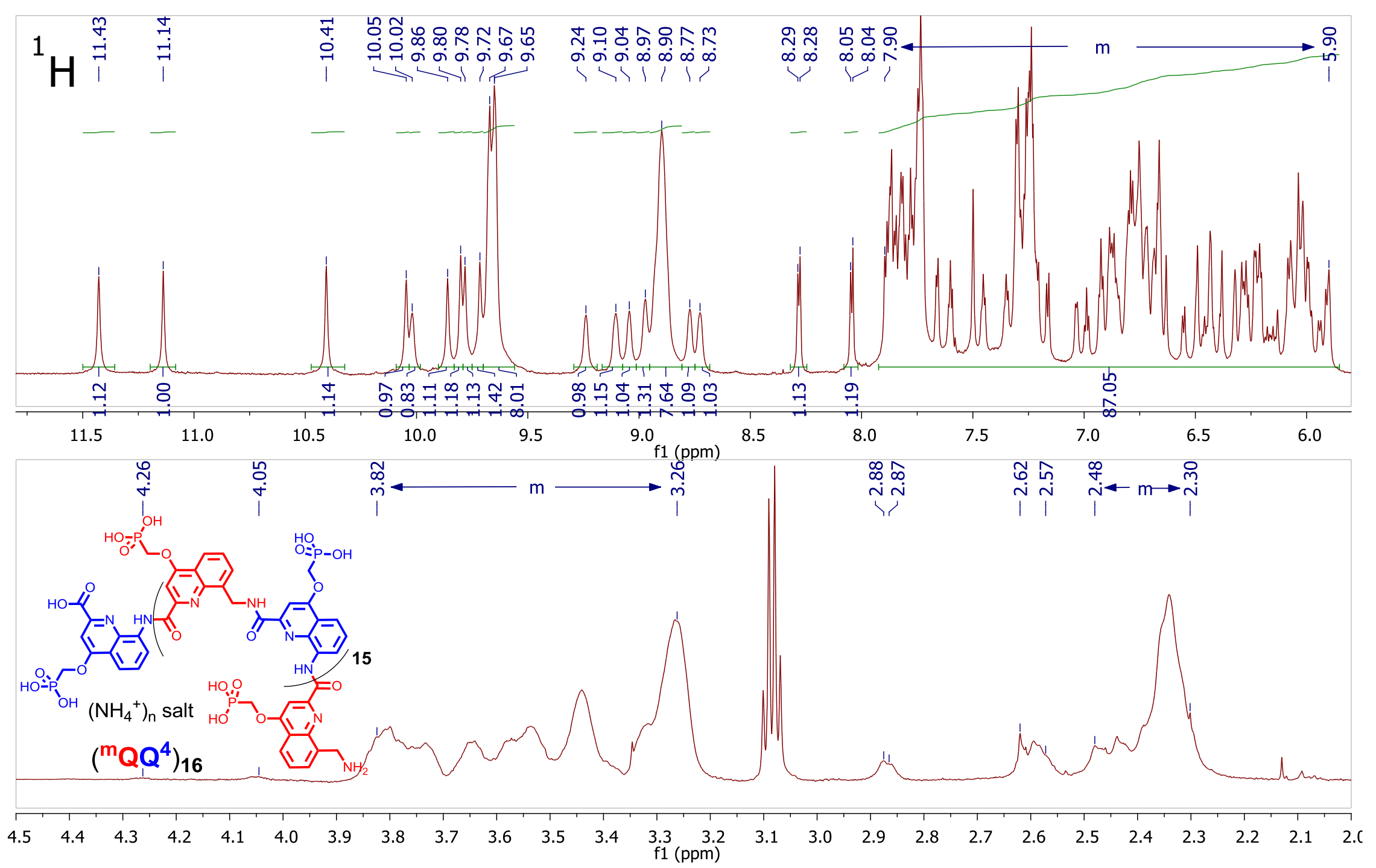




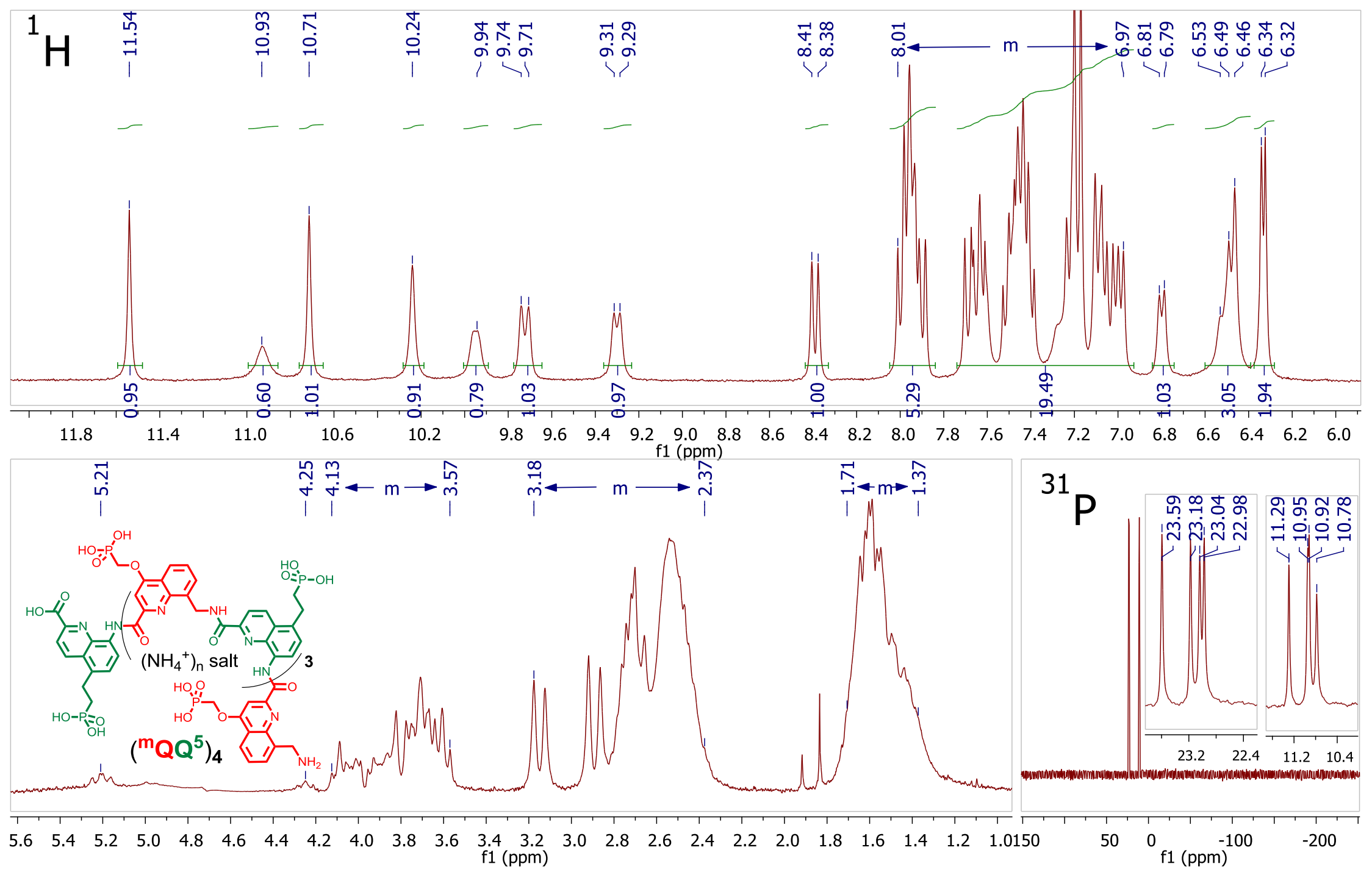




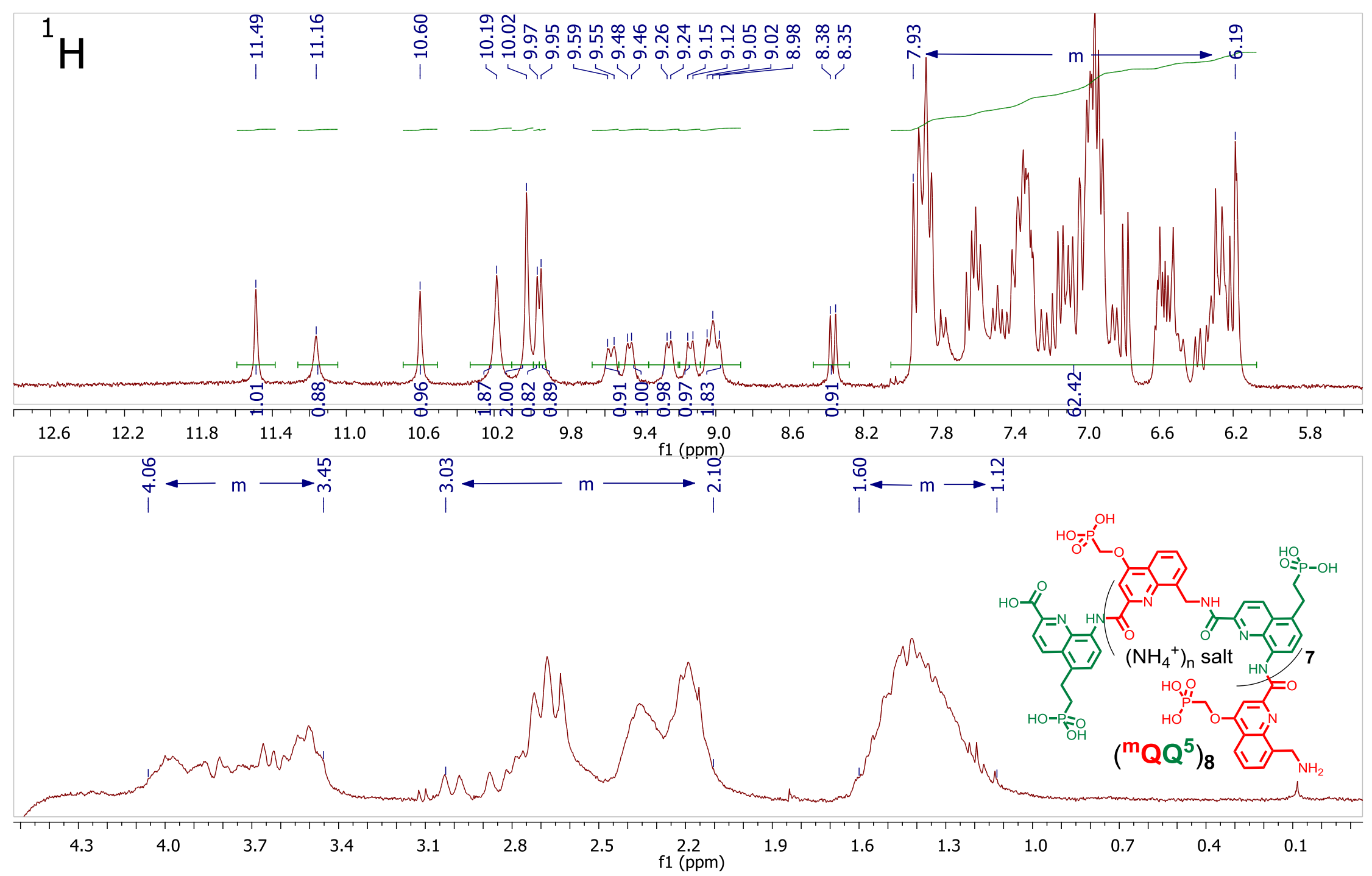

